

\section{BRUNO PINHEIRO RODRIGUES}

ANA CAROLINA DA SILVA BORGES

ERNESTO CERVEIRA DE SENA

HISTÓRIAS AFRO-INDÍGENAS NAS FRONTEIRAS 


\section{Uniedusul Editora \\ Copyright da Uniedusul Editora \\ Editor: Me. Welington Junior Jorge \\ Diagramação e Edição de Arte: Uniedusul Editora \\ Revisão: Patrícia Dayane Acs}

\section{Conselho Editorial}

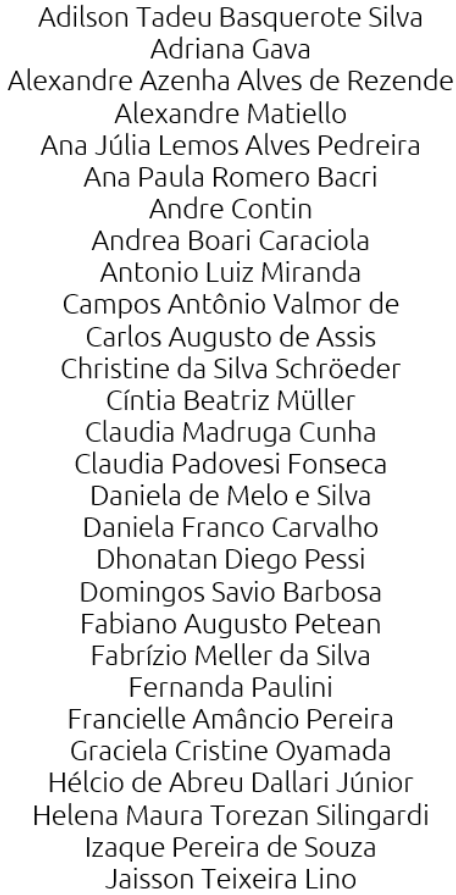

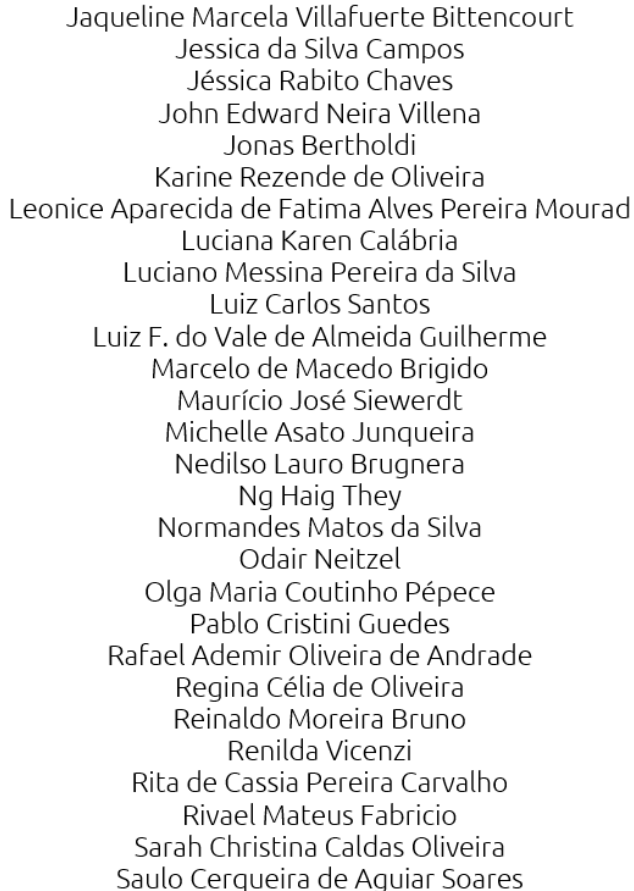

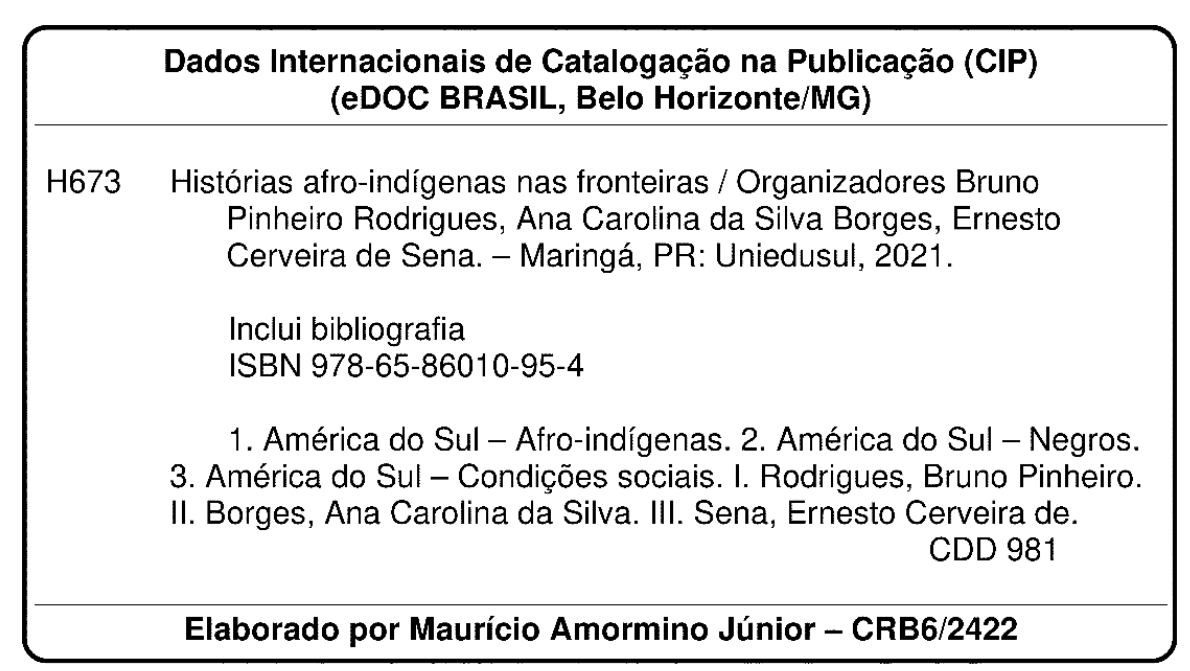

\section{"Este livro foi financiado com recursos do Programa de Apoio à Pós-Graduação (PROAP) da Coordenação de Aperfeiçoamento de Pessoal de Nível Superior (CAPES)."}

O conteúdo dos artigos e seus dados em sua forma, correção e confiabilidade são de responsabilidade exclusiva dos autores.

Permitido fazer download da obra e o compartilhamento desde que sejam atribuídos créditos aos autores, mas sem de nenhuma forma ou utilizá-la para fins comerciais. 


\section{APRESENTAÇÃO}

Dividido em oito capítulos, este livro aborda a história de indígenas e afro-americanos (as) nas regiões de fronteira da América do Sul, em diversas temporalidades. Cada autor e autora é responsável pelo seu texto e, inclusive, esta 'Apresentação' não compartilha a autoria de todas as linhas entre os organizadores - os quais são, também, autores de capítulos. ${ }^{1}$

O capítulo de abertura da coletânea, intitulado "Sedutores da liberdade", é de autoria de Bruno Pinheiro Rodrigues. Reflete o surpreendente quilombo encontrado na região do Vallegrande, atual Bolívia, no ano de 1786. A partir do espaço, o autor analisa as relações entre os impérios de Portugal e Espanha e, particularmente, a agência da população africana nas Américas, visto que o quilombo era constituído principalmente por indivíduos que haviam fugido do Mato Grosso. Ao longo das páginas, também são desenvolvidas reflexões sobre os quilombos nas Américas e áreas de fronteira, a escravidão negra no Alto Peru e suas nuances e as possibilidades de liberdade na América espanhola após a fuga do lado português. O capítulo, em suma, dialoga diretamente com um conjunto de trabalhos elaborados para pensar a história afro-americana no chamado período colonial.

O segundo capítulo, "A identidade quilombola e os remanescentes fora do território", de Cléia Batista da Silva Melo, apresenta reflexões sobre os remanescentes do Quilombo Abolição, município de Santo Antônio do Leverger (Mato Grosso). A pesquisadora, através da aplicação de questionários a 30 pessoas que nasceram no território do quilombo, ainda resistentes do Abolição ou moradoras das cidades vizinhas, verifica a necessidade de ressignificação da noção de "território" e, especialmente, o cuidado com as formações identitárias. Constitui um trabalho importante e que chama atenção para um aspecto de grande relevância na vida da população afro-brasileira contemporânea: o confronto cotidiano entre o ser e o não ser quilombola, a depender do espaço de residência e circulação.

Já o capítulo "Vidas noturnas e diurnas das mulheres negras escravas, forras e libertas (...)" de Jhucyrllene Rodrigues adota como objeto de análise as mulheres que circulavam nos chamados "espaços de divertimento" da freguesia de Pedro II, Cuiabá, Mato Grosso, no século XIX. Por meio de uma gama de documentos localizados no Arquivo Público do Estado de Mato Grosso (APMT) e instigada pela História Social de E. Thompson,

\footnotetext{
1 De modo específico, os três primeiros capítulos da coletânea são apresentados por Bruno Pinheiro Rodrigues. Em seguida, Ernesto Cerveira de Sena apresenta o quarto e quinto capítulos. Os três últimos são por parte de Ana Carolina da Silva Borges.
} 
a autora leva o leitor aos círculos mais íntimos da vida social cuiabana, onde desfilam os mais diferentes sujeitos, de modo particular as mulheres negras escravizadas, forras e livres pobres. Certamente, o fôlego de pesquisa da autora inspirará novos pesquisadores a desbravarem e lançarem luz sobre os tantos sujeitos ainda não analisados da história brasileira.

O texto de Andre Enrique Eltz, "Ocultação e participação indígena no conflito do Chaco", trata de uma das maiores guerras ocorridas na América do Sul, envolvendo o Paraguai e a Bolívia, entre 1932 e 1935; sobre tal guerra, a historiografia mais difundida obliterava as ações e os territórios dos originários da região. $\mathrm{O}$ autor, baseado em diversas fontes, como um diário de militar participante da guerra, mostra a diversidade étnica dos que moravam na região chaquenha e dos que se envolveram no conflito. Assim, debate sobre as formações dos Estados nacionais na América e as tentativas homogeneizadoras de suas populações, logo, de exclusão ou assimilação forçada. Por outro lado, o autor mostra que as pesquisas históricas sobre os indígenas vêm crescendo substancialmente, evidenciando, cada vez mais, as diversidades populacionais em vários eventos conhecidos. $\mathrm{Na}$ Guerra do Chaco, Eltz mostra a dinâmica dos grupos indígenas diante dos militares representantes dos Estados beligerantes. Em uma complexa rede de relações, os grupos indígenas desenvolveram práticas que amenizaram as perdas inevitáveis da guerra, mas também souberam obter ganhos com as partes conflitantes, não reduzindo suas práticas à aculturação ou resistência.

Em outra região de fronteira, Ernesto Cerveira de Sena aborda os indígenas Bororos Coroados, trabalhando, também, com a expansão do Estado Nacional, típico do século XIX e inícios do XX na América. Os governantes e outros da sociedade envolvente planejavam construir uma estrada de Cuiabá até São Paulo. Para isso, teriam de passar pelo território bororo. A reação indígena foi a de avançar até perto da capital de Mato Grosso, causando temor e mortes no caminho. Por outro lado, a tenacidade em abater os coroados foi uma linha contínua, ainda que variando as estratégias dos não-indígenas. Baseado em jornais de época e outros documentos depositados em diferentes arquivos, além de bibliografia pertinente, o autor mostra que continuaram as expedições para matar e sequestrar os bororos, ao lado de apropriação de suas terras, apesar da proibição de se fazer "bandeiras". As guerras contra os Bororos terminaram somente depois de aproximadamente quatro décadas de conflitos intensos, quando conseguem mover muitos deles para aldeamentos. Os não-índígenas não só passam a dispor do antigo território bororo, como também de sua mão-de-obra. 
No capítulo "Circulando a través del calor: una etnografía sobre el fuego y la cocina en los misak-guambianos", o autor lança mão de uma metodologia etnográfica com a intenção de compreender a continuidade do povo Misak no norte dos Andes, suplantado pelo espaço de maior aprendizagem interna e de caráter intergeracional - o Nak Chak (fogo-fogão). As dinâmicas sociais ao redor da cozinha, as ações ritualísticas que envolvem o fogo, guarnecida pela conexão e vida com seus ancestrais, os enredos e os discursos propalados nas experiências compartilhadas cotidianamente, possibilitaram ao pesquisador adentrar no universo cosmológico da etnia tratada. Para isso, teve como suporte as narrativas e relatos que constroem a memória local, o sistema de pensamento Misak, bem como as resistências deste povo a partir da recuperação de terras. Dentre as grandes contribuições explicativas proporcionadas nesse capítulo, destaca-se a maneira como construiu seu objeto/sujeito de pesquisa, na medida em que propôs uma escrita na qual coloca o pesquisador e seus interlocutores no mesmo nível.

No capítulo seguinte, intitulado “'Subalternos da colonialidade': diferenças, dominações e explorações impostas pelo sistema moderno-colonial aos povos indígenas do Mato Grosso no século XIX", a autora centrou sua análise em dois movimentos que se articulam, a adoção e o batismo, tendo como base Cibaé Modojebá (Rosa Bororo). Essa figura feminina, comumente revisitada pela historiografia indígena de Mato Grosso, foi uma mulher indígena Bororo capturada em uma das ações "pacificadoras" nas últimas décadas do século XIX (1880); ações capitaneadas pelo alferes Antônio José Duarte. A mesma tornou-se interprete e mediadora entre a sua etnia e a elite da província, especialmente, os grupos militares e da aristocracia do período. Aspectos que são os mais discutidos na bibliografia construída a respeito da "Rosa Bororo". Contudo, as discussões da autora miram a temática da família em uma perspectiva inter-racial e subjetiva, apontando a originalidade de suas reflexões. Para construir essa interpretação histórica, selecionou um conjunto de tipologias documentais, quais sejam, registros de batismos na Paróquia Senhor Bom Jesus de Cuiabá no período entre 1853 e 1890, Relatórios da Diretoria Geral do Índio, Revistas e Jornais da época e Leis de Adoção.

No capítulo final que fecha o livro, denominado "Guatós e seu mundo fronteiriço: 'índios canoeiros' navegando no contradiscurso, uma proposta analítica histórica decolonial", a historiadora deu atenção ao grupo indígena Guató, entre os anos de 1830 e 1930. Com a prerrogativa de montar uma escrita que os coloquem como protagonistas históricos e colaborativos, formulou uma discussão epistemológica e de natureza transdisciplinar em sua narrativa. Pensando nisso, a autora analisou a bibliografia montada sobre a etnia tratada, entrecruzou relatos de naturalistas, cronistas e viajantes nacionais e 
internacionais e problematizou conceitos e categorias interpretativas que reduzem e simplificam os contextos e trajetórias de ocupação territorial dos Guatós. Com a finalidade de romper com essas versões científicas, optou por desenvolver análises paradigmáticas que reformulam a interação desses grupos indígenas com o meio em que operam, adentrando no forte vínculo que desenvolviam entre si e com a natureza. Assim, pode redimensionar a contribuição paisagística e humana no bioma que praticaram e ainda praticam: o Pantanal. 


\section{SUMÁRIO}

CAPÍTULO 1 .09

"Sedutores da liberdade: a história de um palenque formado no Alto Peru com negros fugidos do Mato Grosso (1783)"

Bruno Pinheiro Rodrigues

doi: $10.51324 / 86010954.1$

CAPÍTULO 2 27

"A identidade quilombola e os remanescentes fora do território: uma realidade da comunidade Abolição e das tantas outras"

Cléia Batista da Silva Melo

doi: $10.51324 / 86010954.2$

CAPÍTULO 3 .45

Vidas noturnas e diurnas das mulheres negras escravas, forras e libertas em suas atividades cotidianas: tempo, trabalho, divertimento e boemia na freguesia de Pedro II (Mato Grosso, século XIX)

Jhucyrllene Campos dos Santos Rodrigues

doi: $10.51324 / 86010954.3$

CAPÍTULO 4 .64

Os Bororos Coroados e a política indigenista em Mato Grosso - bandeiras e outras transformações "para desinfestar os sertões"

Ernesto Cerveira de Sena

doi: $10.51324 / 86010954.4$

CAPÍTULO 5 .82

Ocultação e participação indígena no conflito do Chaco - (1932-1935)

André Henrique Eltz

doi: $10.51324 / 86010954.5$

CAPÍTULO 6

"Circulando A Través Del Calor: una etnografía sobre el fuego y la cocina en los misakguambianos"

Duvan Murillo Escobar

doi: $10.51324 / 86010954.6$

CAPÍTULO 7

"Subalternos da colonialidade": diferenças, dominações e explorações impostas pelo sistema moderno-colonial aos povos indígenas do Mato Grosso no século XIX

Maria Ester de Siqueira Rosin Sartori

doi: $10.51324 / 86010954.7$

CAPÍTULO 8 .135

Guatós e seu mundo fronteiriço: índios canoeiros navegando no contradiscurso, uma proposta analítica histórica

Ana Carolina da Silva Borges

doi: $10.51324 / 86010954.8$ 
Era o ano de 1786 quando autoridades espanholas decidiram organizar uma expedição para captura de homens negros na região do Vallegrande, localizada hoje entre as cidades de Santa Cruz de la Sierra e Cochabamba, na Bolívia. As autoridades se fundamentavam, principalmente, na reclamação de alguns proprietários de que esses homens eram negros fugidos dos domínios de Portugal e que, além de praticar roubos, estavam seduzindo outros negros escravizados para a fuga. Alegavam que haviam construído uma espécie de "forte" e, caso não fossem tomadas providências, o ajuntamento tenderia a aumentar.

Diante das informações, nota-se uma estreita semelhança desse ajuntamento com o que identificamos na história luso-brasileira como quilombos e mocambos. Embora o fato não seja inédito na história latino-americana, acredito que ele nos permita refletir numerosos temas; como a vida pós-fuga de um negro, as diferenças e semelhanças entre as Américas portuguesa e espanhola no que tange à repressão escravista aos que rompiam com o sistema e o leque de ações e alianças possíveis para manutenção da liberdade.

Destarte, o presente capítulo, inicialmente, tecerá uma reflexão sobre os "ajuntamentos" de cativos fugidos da escravidão nas Américas, realçando semelhanças e nuances; e, em um segundo momento, analisará o espaço supracitado à luz das relações da Bolívia e Mato Grosso com a escravidão negra e a agência desses sujeitos.

\section{Entre quilombos, palenques, cimarrons e marrons: agrupamentos de negros fugidos da escravidão nas Américas}

Não restam dúvidas de que a escravidão transatlântica seja um dos fatores mais relevantes e marcantes da chamada modernidade. Envolvendo milhões de sujeitos em diferentes partes do mundo por quase quatro séculos, foi capaz de desmontar, estruturar e reestruturar dezenas de milhares de sociedades. Principalmente, foi responsável pela

\footnotetext{
${ }^{2}$ Bruno Pinheiro Rodrigues é doutor em história e professor da Universidade Federal de Mato Grosso, vinculado ao Departamento de História. E-mail: professorbrunorodrigues@yahoo.com.br
} 
diasporização nas Américas de cerca de 12 milhões e meio de africanos, forçados ao trabalho nos mais diferentes setores econômicos - extração de minérios, pecuária, agricultura, entre outros. De uma ponta a outra do continente, essa massa de homens e mulheres, parafraseando Antonil (1982, p.89), foi tomada como mãos e pés de todo um sistema socioeconômico forjado.

Para além das nuances assumidas pela escravidão nas Américas, um dos fatos mais comuns foi a existência de fugas e subsequente formação de agrupamentos, que, a depender da localidade nas Américas, receberam designações variadas: palenques, cumbes ou cimarrón na América espanhola; maroons na América inglesa; grand marronage nos territórios franceses; e na, América portuguesa, além do "quilombo", também o termo "mocambo" - habitantes desses espaços poderiam ser chamados de quilombolas, calhambolas ou mocambeiros.

De acordo com Silvia Hunold Lara (1996, p. 97), apesar das definições desses agrupamentos serem assemelhadas, assentam-se sobre bases diferentes: ora consideravam a distância do lugar onde se estabeleceram, ora davam primazia à disposição para resistência à captura ou mesmo para a ênfase na capacidade de sobreviver por longa duração nas matas.

Em todo caso, tais comunidades, como afirma Richard Price (1996, p. 52), representavam a antítese de tudo o que a escravidão representava ou, ainda, a existência de uma consciência escrava que se recusava a ser limitada ou manipulada. Como argumenta Carlos Magno Guimarães (1996, pp.139-154), os "quilombos" eram a contradição básica da realidade escravista, pois representavam a retirada do cativo do processo produtivo, impossibilidade de reposição do capital investido em sua aquisição, gastos exigidos para montagem da repressão (bandeiras de captura), prejuízos materiais em decorrência das atividades desenvolvidas por quilombolas (assaltos, incêndios, sedução para novas fugas), entre outros.

Para o caso luso-brasileiro, salientam João José Reis e Flávio dos Santos Gomes:

(...) Os quilombolas brasileiros ocuparam sertões e florestas, cercaram e penetraram em cidades, vilas, garimpos, engenhos e fazendas; foram atacados e usados por grupos escravistas, aos quais também atacaram e usaram em causa própria.; fugiram da escravidão e se comprometeram com a escravidão; combateram e se aliaram com outros negros, índios e brancos pobres; criaram economias próprias e muitas vezes prósperas; formaram grupos pequenos, ágeis, móveis e temporários, ou grupos maiores, sedentários, com gerações que se sucediam, politicamente estruturados; envolveram-se com movimentos políticos de outros setores sociais, desenvolveram seus próprios movimentos, alguns abolicionistas; aproveitaram-se de conjunturas políticas conflitivas nacionais, regionais, até internacionais, para crescer, ampliar alianças, fazer avançar seus interesses 
imediatos e projetos de liberdade mais ambiciosos (REIS; GOMES, 1996, p. 23).

Nos territórios dominados pela Espanha, Inglaterra e outras potências europeias, o cenário não destoou do descrito acima. Nota-se nesses lugares que os palenques, cumbes, marrons, entre outras denominações, comumente se constituíam nas "franjas das plantations", minas e cidades; ou seja, nas áreas de bosques ou pântanos, tendo em vista a proteção ante caçadores de escravizados e acesso a recursos que os meios ofereciam, como possibilidade de pesca, caça, obtenção de lenha etc. (FLORENTINO; AMANTINO, 2012, pp. 246-7).

Tais espaços formavam-se comumente a partir de fugas realizadas em momentos de depressão, pré ou pós-revoltas. Em 1626, por exemplo, em meio a saques de piratas holandeses no Caribe espanhol, escravizados fugiram para a montanha e alguns, inclusive, se juntaram a piratas em expedições posteriores (THORNTON, 2004, p.362).

A predominância africana entre a população cativa também esteve mais associada, nas Américas, às fugas e subsequente formação de ajuntamentos. Sugerem Florentino e Amantino (2012, p. 242) que a considerável presença de africanos fugidos nos inventários post-mortem, juntamente com os avisos nos jornais, indica que corresponderiam eles ao maior montante entre os fugitivos. Segundo os autores, pairava nas Américas um certo "romantismo" em relação à propensão natural dos africanos recém-desembarcados nas Américas para a fuga, relativo a ideia de que todo indivíduo chegado da África fosse potencialmente um cimarrón.

Outrossim, é preciso atentar para os efeitos das políticas de alforrias na incidência de fugas em áreas nas quais as "libertações" eram culturalmente incorporadas nas relações de senhores e escravizados. ${ }^{3}$ Do ponto de vista econômico, nota-se a concessão de maiores possibilidades de manumissão em períodos de recessão, a fim de que se revertesse parte dos preços pagos por cativos. Nesses momentos, o preço de um cativo barateava e acabava por ser possível a compra da própria alforria. Por outro lado, em períodos de estabilidade econômica, havia alta de preços, impossibilidade de compra da própria alforria e, consequentemente, mais fugas e formação de quilombos (FLORENTINO; AMANTINO, 2012, p. 244).

No mundo hispânico, diante do conjunto de leis chamado Siete Partidas, há uma certa clareza sobre as libertações como elementos culturalmente incorporadas.

\footnotetext{
${ }^{3}$ O esquema descrito no parágrafo não era aplicável a toda a América. Florentino e Amantino (2012, p. 244) trazem o caso da Virgínia, que, ainda no final do século XVII, proibira a manumissão privada, a menos que o senhor enviasse para fora da colônia o cativo libertado.
} 
Recompiladas no século XIII por Afonso X, tais leis foram largamente utilizadas na fundamentação de concessões de manumissões. Comumente, como estratégias jurídicas observadas em processos de alforria nos tribunais, vinculava-se o cativo à figura do "servo" ou "peça", já que na Siete Partidas o servo detinha a possibilidade de requerer ao senhor a garantia da alimentação, vestimenta e assistência médica. Além disso, esse conjunto de leis possibilitava ainda quatro "consolações": eleição de um servo menos severo, a faculdade de casar-se seguindo a própria escolha, a possibilidade de comprar a liberdade e o direito de possuir alguma coisa (SECRETO, 2011, p. 137-148).

Acrescenta-se a isso o fato de muitos cativos aproveitarem as situações de instabilidade política no mundo senhorial para realização de fugas, que poderiam resultar ou não em formação de quilombos. Durante as guerras de independência ocorridas nas Américas, por exemplo, um homem negro detinha diante de si três cenários principais: redução de controle decorrente do tumulto simultâneo ao aumento das possibilidades de fuga; possibilidade da obtenção da liberdade pelo serviço militar; e, finalmente, a aprovação gradual de programas de emancipação. Acerca desse último ponto, é perceptível como as demandas provadas por soldados negros nas guerras nas Américas espanholas pesaram para aprovação de leis de ventre livre ou abolição definitiva. Na América hispânica, com exceção de Cuba e Porto Rico, todos os países aderiram à abolição gradual da escravidão através de leis de ventre livre entre as décadas de 1810 e 1840 (ANDREWS, 2007, pp.8788). 4

Os estudos sobre os grupos subalternizados nas fronteiras entre o Brasil meridional e a chamada Banda Oriental (atual Uruguai) demonstram fatos que seguem a mesma lógica. Na região, diferentes fontes apontam que a população cativa diante dos conflitos fronteiriços percebeu oportunidades na guerra: alistamento para futura reivindicação de alforria; ruptura com a escravidão através de fugas para tropas; obtenção de prestígio junto a senhores e tessitura de relações de compadrio (CARVALHO, 2013, p.112).

Tanto durante a Guerra Civil Farroupilha (1835-1845) do Rio Grande do Sul como na Grande Guerra (1839-1851) travada em solo uruguaio entre blancos e colorados, Daniela Carvalho (2013, p. 115) nota o aumento do fluxo de fugas de cativos do lado brasileiro para o outro lado da fronteira, o que sugere, segundo a autora, que a população escravizada pudesse estar atenta às condições mais favoráveis para os seus projetos de liberdade. Para a autora:

\footnotetext{
${ }^{4}$ Ver especialmente a tabela comparativa elaborada por Andrews (, p. 87).
} 
Sumos que buscavam antes proteção que propriamente as tropas militares e policiais. No entanto, sentar praça foi o caminho que encontraram em suas rotas de fuga. Estes escravos buscaram proteção junto aos inimigos de seus senhores, onde pareciam apostar que tal conjuntura, se não lhes oferecia melhores condições de vida, ao menos Ihes garantiria o não retorno a seus antigos senhores. Que, o fim e ao cabo, aponta para um relativo sucesso na empreitada da fuga (CARVALHO, 2013, p. 121).

Não podemos perder de vista que no ato de fuga de um cativo, além do protagonismo do próprio sujeito, poderia haver outros sujeitos envolvidos. Mariana Flores (2013), por exemplo, identificou, entre 1850 a 1877, o registro de 21 casos de fuga de escravizados dos municípios de Alegrete, Uruguaiana, Santana do Livramento e Quaraí. Desses, em 14 processos, são mencionadas a ação de "sedutores", ou seja, pessoas que participaram da fuga convencendo o cativo a atravessar a fronteira e, em alguns casos, viabilizando condições de fuga. No auto de perguntas feitas a Cypriano e Paulo, que foram capturados em 24 de novembro de 1870, são mencionados o preto forro João Thomaz e o paraguaio José. Para Cypriano, foi prometida liberdade e a Paulo, que poderia ganhar muito dinheiro do outro lado da fronteira, além dela, cavalo e arma para travessia (FLORES, 2013, p. 153).

Por outro lado, é importante não perder de vista que a realização de fugas e subsequente formação de agrupamentos ocorreram independente das instabilidades políticas do mundo escravista. A história dos cimarrons nas proximidades de Cartagena, em Nueva Granada, é exemplar nesse sentido. Formados inicialmente no limiar do século XVII, sob liderança de Domingo Bioho, o Benkos, os agrupamentos se estabeleceram em montes próximos ao porto, onde constituíram comunidades autónomas e guarnecidas militar, econômica e politicamente. Apesar das expedições organizadas para captura dos fugitivos, os espaços se mantiveram a tal ponto que em 1605 o governador da região, don Jerônimo de Suazo y Cassola, se viu obrigado a firmar um tratado de paz com os cimarrones (FALS BORDA, 2002; NAVARRETE, 2003). Contudo, ao contrário da interrupção das fugas, o que se observará ao longo do século será o aumento e consequente formação de cimarrons - registra-se que, entre 1600 a 1694, tenham existido nos entornos de Cartagena três comunidades de fugitivos (FRIEDEMANN, 1993, p. 70).

O caso dos cimarrons nas proximidades de Cartagena revela ainda outro aspecto da agência dos homens e mulheres escravizados nas Américas: a tessitura de projetos políticos autónomos, a despeito dos conflitos políticos escravistas. Em 30 de abril de 1693, por exemplo, a suposta descoberta de um plano de ataque que aliava cimarrones, negros escravizados e livres contra a cidade, levou a população ao pânico. Descoberto pelo monge do convento de San Augustín, Joseph Sánchez, inicialmente indicava a participação de 
quatro africanos escravizados e um negro livre, que atacariam Cartagena com o apoio dos cimarrones. A cidade se encontrava desprotegida no período devido às campanhas militares movidas contra os próprios cimarrons na região. Após a denúncia, seguiram-se prisões e interrogatórios que demonstravam, entre outras coisas, os contatos entre a população negra que habitava a cidade e os que haviam rompido com a escravidão e viviam em agrupamentos (LÓPEZ, 2006).

Em 1809, na cidade de Santa Cruz de la Sierra (Alto Peru), um inquérito iniciado junto ao cabildo da cidade nos informa uma aliança similar, para além dos conflitos do mundo senhorial. Na ocasião, as autoridades da cidade tomaram conhecimento, no mês de agosto, de que negros escravizados, livres juntamente com indígenas chiriguanaes, planejavam atacar a cidade e assassinar a população branca. Assim como o episódio narrado anteriormente, as autoridades da cidade se anteciparam ao levante, efetuaram prisões e seguiu um longo inquérito para entender quem eram as lideranças e quais poderiam ter sido as motivações. Entre as informações obtidas, apurou-se: as lideranças eram africanas que haviam fugido do Mato Grosso (capitania da América portuguesa) e que viviam como livres na cidade e imediações, constantemente sob a ameaça da deportação; que negros livres poderiam ter sido motivados por uma suposta alforria concedida pelo rei, omitida pela classe senhorial e autoridades locais; e indígenas, que eram tributados desde o século XVIII, caso o plano fosse bem-sucedido, teriam a oportunidade de isenção. Em outras palavras, interesses diferenciados e um inimigo em comum: a classe senhorial e autoridades castelhanas. Posteriormente, as lideranças foram enviadas a La Plata, punidas com trabalhos forçados em uma panederia, e depois absolvidos, sob a condição de pagamento de fianças (RODRIGUES, 2016a, p. 219). ${ }^{5}$

Em todo caso, no que tange às relações de habitantes de agrupamentos externos à sociedade escravista com a população escravizada, na historiografia brasileira existe uma fartura de trabalhos que podem ser recordados, como a obra de Flávio dos Santos Gomes. Em linhas gerais, o autor parte do pressuposto da inviabilidade de se entender os quilombos como espaços isolados, defendendo que esses fossem articulados e interagissem de diversas maneiras com grupos externos, inclusive com negros que permaneciam na escravidão. Segundo Gomes (1997, p. 16):

(...) Uma característica fundamental dos quilombos foi, para maior parte deles, a paulatina gestação de uma economia de base camponesa. Os quilombos procuravam se fixar não muito distante de locais onde pudessem

\footnotetext{
${ }^{5}$ Vale lembrar que Santa Cruz de la Sierra era a unidade governamental espanhola mais próxima da América portuguesa. Ao longo dos séculos XVIII e XIX, houve considerável fluxo de fugas de cativos negros do lado português ao espanhol. Sobre isso, ver Rodrigues (2016b).
} 
efetuar trocas mercantis. Mesmo quando procuravam refúgios em longínquas florestas não permaneceram isolados. Desenvolveriam mesmo atividades econômicas que se integraram à economia local. Através de relações socioeconômicas clandestinas contavam com a proteção de taberneiros, pequenos lavradores e principalmente dos escravos de determinadas regiões. Em muitas áreas e contextos houve uma paulatina integração socioeconômica, envolvendo as práticas camponesas dos quilombolas com a economia própria dos escravos nas parcelas de terras a eles destinados por seus senhores.

O exame dos agrupamentos de negros fugidos da escravidão no oriente cubano, entre os séculos XVIII e XIX, igualmente nos mostra esse aspecto notado por Gomes para a realidade luso-brasileira. Na região, em palavras de Belmonte Postigo (2007, p. 10), as fugas constituíam um verdadeiro problema endémico e ocorriam tanto dos espaços urbanos como rurais. Nas áreas rurais, especialmente, a presença dos negros fugidos causava diversas preocupações, devido aos assaltos e roubos às fazendas. Nota o autor que a proliferação dos cimarrons na ilha acabou por resultar no aumento dos mecanismos de vigilância da população cativa e repressão às atividades cimarrones, como divulgação de prêmios por captura de fugitivos; particularmente após a independência do Haiti e avanço da fronteira agrícola na parte oriental da ilha de Cuba.

De qualquer modo, em 1815, após um ataque sofrido nas fazendas de Sierra de Limones y Contramestre, as autoridades cubanas decidiram destruir o palenque "El Frijol", considerado um dos maiores na região. Tal campanha legou um relato que detalhou diversos aspectos dos agrupamentos de negros fugidos na ilha de Cuba, como atividades econômicas, políticas, táticas guerreiras, estratégias de novas fugas em situações de ataques, maneiras para despistar de capitães do mato, entre outras. Chamamos atenção para o trecho em que descreve as relações entre os negros fugidos e os que eram mantidos na escravidão:

(...) o primeiro caminho que encontram para negociação da cera são os negros dos rebanhos, e engenhos próximos, ou remotos dos nomeados palenques com os que ordinariamente estão confabulados sem a menor transcendência dos senhores do fundo, e se guarda tão religiosamente este segredo por cinquenta, ou cem negros de uma de muitas fazendas como faz o mais importante do estado guardando um ministro fiel a seu soberano, de modo que nenhum castigo é o bastante para dobrar a esses negros a confessar as relações que têm com esses fugitivos [grifo nosso] (BELMONTE POSTIGO, 2007, p. 18, tradução nossa). ${ }^{6}$

\footnotetext{
6 “(...) El primer camino que encuentran para la negociación de la cera es la de los negros esclavos de los hatos, e ingenios cercanos, o remotos de los nombrados palenques con los que ordinariamente están confabulados sin la menor trascendencia de los señores del fundo, y se guarda tan religiosamente este secreto por cincuenta, o cien negros de una de muchas haciendas como podrá en lo mas importante del estado guardando un ministro fiel a su soberano, de modo que ningún castigo es bastante para doblegar a estos negros a confesar las relaciones que tienen con estos fugitivos (...)" (BELMONTE POSTIGO, 2007, p. 18).
} 
É necessário realçar a firmeza e lealdade tecida entre os sujeitos aquilombados e assenzalados, que não entregavam as minúcias das suas relações nem sob ameaças e torturas. Seguindo o relato, detalha quais eram os produtos escambados:

(...) Esses ordinariamente introduzem a cera no centro de um canavial, e dali vão exportando os domésticos de um engenho nos dias feriados a cidade onde vendem ao catalão trapaceiro que com bajulação talvez não desconhecendo a origem daquela mercadoria sem fazer desembolsos os provem em troca de machados, facões, pólvora, pedras de faísca, colegas, listados, sal e outros artigos que esses negros cafetões pela mesma ordem vão insensivelmente transportando ao lugar do depósito de onde descem os cimarrones para leva-los as suas tocas (BELMONTE POSTIGO, 2007, p. 18 , tradução nossa). ${ }^{7}$

Não podemos perder de vista também a atenção dos negros fugidos da escravidão para com os que eram mantidos no cativeiro, tanto por uma questão de viabilidade da sobrevivência (como vimos acima), como pela percepção do sofrimento, empatia ou manutenção de alianças provisórias. Em 1857, em meio às negociações de paz entre as autoridades do Suriname e quilombolas, um líder negro repeliu o emissário do governo e indagou sobre como se portavam como civilizados, ao mesmo tempo que agiam com crueldade com a população escravizada. O conselho, reportado pelo capitão Stedman, se deu nos seguintes termos:

Desejamos que diga ao governador e sua corte que, caso não queiram novos levantes de bandos de rebeldes, devem cuidar para que os fazendeiros vigiem mais de perto suas propriedades, não as entregando com tanta frequência nas mãos de administradores e feitores bêbados que... são a ruína da colônia e fazem fugir para o mato um grande número de gente ativa e destemida (...) (GENOVESE, 1983, p. 67).

Decerto, diversos outros aspectos poderiam ser enquadrados em um texto que se propõe a pensar de forma panorâmica os agrupamentos formados por negros fugidos da escravidão nas Américas. Do atual sul dos Estados Unidos ao extremo sul das Américas, existem numerosos casos relacionados à temática. É possível estabelecer um padrão comum a todos esses agrupamentos? Com exceção do processo de formação marcado pela ruptura com a ordem escravista através da fuga desejada ser definitiva, penso que

\footnotetext{
7 (...) Estos ordinariamente introducen la cera en el centro de um cañaveral, y de allí la van exportando los domésticos de un ingenio en los días feriados a la ciudad donde la venden al catalán39 marrullero que con halagos acaso no desconociendo el origen de aquella mercadería sin hacer desembolsos los proveen em cambio de hachas, machetes, pólvora, piedras de chispa, coletas, listados, sal y otros artículos que estos negros alcahuetes por el mismo orden van insensiblemente transportando al lugar del depósito donde bajan los cimarrones a llevarlos a su guaridas (...) (BELMONTE POSTIGO, 2007, p.18)
} 
não. A configuração de cada quilombo, bem como a sua longevidade, depende de vários fatores: perfil do africano fugido, viabilidade agrícola e defensiva da área na qual foi formado o agrupamento, perfil da população indígena existente na região (se for o caso) e nível de estabelecimento colonial na região, que, por sua vez, está estreitamente associado com a capacidade bélica para reprimir quilombos e palenques. Isso posto, na sequência, analisaremos o agrupamento do Alto Peru de 1786.

\section{O palenque do Vallegrande}

O palenque talvez seja o único ou o mais relevante registrado no período colonial no Alto Peru. Não obstante as poucas reflexões realizadas sobre o caso, avalio que ele nos dê oportunidade para análise do lugar do homem negro na América espanhola, os possíveis desdobramentos dos que fugiam da escravidão no lado português e, principalmente, as estratégias lançadas por esses sujeitos para a vida às margens das sociedades escravistas.

Na mesma época em que foi descoberto, na passagem do século XVIII para o XIX, deveriam existir por toda a América espanhola cerca de 550 mil negros em condição de escravidão e um número igual ou superior de livres (BOWSER, 1990, p. 144). Essa massa de homens e mulheres estava distribuída por todo o tecido social, de uma ponta a outra das Américas, com maior ou menor presença, a depender da atividade econômica desenvolvida na região. Em linhas gerais, enquanto apresentava baixa densidade demográfica negra nas atividades econômicas que envolviam a exploração da prata, detinha maior expressão na extração do ouro de aluvião e agricultura. ${ }^{8}$

No caso específico do Alto Peru, a população negra possivelmente nunca chegou a ultrapassar a média de $15 \%$ do total de habitantes registrados. Disseminada por todo o tecido social, encontrava-se nos espaços urbanos, fazendas produtoras de frutas, coca, olivares e vinhedos. Um levantamento elaborado por Esther Soria (2010, p. 237) com base em diversas fontes provenientes do final do século XVIII nos ajuda a entender a dimensão desse grupo no Alto Peru. Nele, consta que a população negra e mulata no período perfazia 11,5\% em La Plata, 4\% em Potosí, 9,2\% em Cochabamba e 38,5\% na região do Vallegrande. Importante observar que a última localidade estava inserida na intendência de

\footnotetext{
${ }^{8} \mathrm{~A}$ baixa densidade demográfica da população negra na exploração da prata no México e elevada presença negra na extração do ouro de aluvião em Nova Granada (especialmente em Antióquia, Popayá e El Chóco), cana-de-açúcar, trigo, vinho e horticultura no Peru, exemplificam essa máxima. Para se ter uma ideia, no final do século XVIII, enquanto o México contava apenas com 10 mil cativos, o Peru chegava a cerca de 83 mil (BOWSER, 1990, p. 145).
} 
Santa Cruz de la Sierra, região vizinha da Capitania de Mato Grosso e, portanto, principal destino de fuga entre as coroas portuguesa e espanhola.

Apesar de existirem outros destinos para a América portuguesa, Santa Cruz de la Sierra foi o destino mais frequente dos cativos que fugiram do Mato Grosso ao longo dos séculos XVIII e XIX. Tanto nos arquivos coloniais de Portugal como nos da Espanha, constam numerosos documentos que atestam esse fluxo. ${ }^{9}$

A despeito do fluxo de negros entre as fronteiras ibéricas, na virada do século XVIII para o XIX, havia no Alto Peru cerca de 21.010 indivíduos na condição de escravidão, o que perfazia $12 \%$ do total de habitantes. A maior parte trazida à região através de três rotas, sendo a primeira o circuito comercial que articulava zonas portuárias nas Antilhas, Santo Domingo e Panamá. Nesse, o deslocamento de um cativo até chegar ao Alto Peru poderia se estender em até 9 meses, em decorrência da necessidade de se atravessar o Canal do Panamá. De acordo com Rodas:

Pelo que toca aos escravos destinados ao Peru, esses chegaram ou eram entregues em Nome de Deus, porto situado nas margens do golfo do México. Dali deviam atravessar o istmo para chegar ao Panamá, sobre o oceano Pacífico. Do Panamá uma nova travessia até o porto de Callao, que era o grande ponto de distribuição ao Perú [tradução nossa] (RODAS, 1977, p.24). ${ }^{10}$

Com o início da colonização de Tucumán (atual Argentina) e fundação de Buenos Aires, abriu-se uma segunda possibilidade de entrada de cativos no Alto Peru, via bacia do rio Prata. Ao longo dos séculos, a rota tornou-se atraente porque reduzia em milhares de quilômetros o deslocamento, tempo e preço da mão-de-obra escravizada. ${ }^{11}$ Mesmo com os protestos do grupo comercial escravista de Lima, que nos idos do final do século XVI se encontrava em posição sólida, Buenos Aires passou a hegemonizar, progressivamente, a distribuição de cativos ao sul da América.

\footnotetext{
${ }^{9}$ Além de Santa Cruz de la Sierra, a população cativa que se evadia do Mato Grosso poderia trilhar outros caminhos em direção à América espanhola: as missões dos Mojos e Chiquitos, Assunção, Buenos Aires, Cordoba, Tucumán e, em algumas situações, o Peru. De maneira geral, pelo Vale do Guaporé, cativos se evadiam para Mojos e Santa Cruz de La Sierra, e, pelo Vale do Paraguai, para as demais localidades. Sobre fugas de cativos do Mato Grosso para América espanhola, ver Bruno Rodrigues (2016), Ernesto Cerveira de Sena (2013) e Monique Lordelo (2019).

10 Texto original: Por lo que toca a los esclavos destinados al Perú, éstos llegaban o eran entregados en Nombre de Dios, puerto situado a orillas del golfo de México. De allí debían atravesar el istmo para llegar a Panamá, sobre el océano Pacífico. De Panamá una nueva travesía hacia el puerto del Callao, que era el gran punto de distribución en el Perú (RODAS, 1977, p. 24).

${ }_{11}$ De acordo com Rodas, "(...)La disminución hasta la llegada al Callao representa miles de kilómetros. Al acortarse la travesía, se reducía no sólo el tiempo empleado en el viaje, sino también -como consecuencia natural de ese hecho- el porcentaje de bajas entre los esclavos, ya que está probado por varios lados, además de la lógica, que la duración de la travesía estaba directamente relacionada con el volumen de la carga que llegaba en buenas condiciones a los puertos de destino." (RODAS, 1977, p. 24).
} 
A terceira forma de entrada de cativos no Alto Peru se deu por meio do circuito do contrabando, que basicamente era formado pelo triângulo entre autoridades espanholas, comerciantes portugueses e contrabandistas. No Alto Peru, operava em duas frentes, na bacia do rio Prata, a partir da Colônia do Sacramento, Montevidéu e Buenos Aires; e pela região dos Mojos, fronteira com o Mato Grosso. Embora não seja possível saber numericamente quantos homens e mulheres foram introduzidos de forma clandestina no Alto Peru, é possível supor que o fator que motivara tal circuito fosse a possibilidade de obtenção de maiores lucros com o comércio escravista, haja vista o não-pagamento de impostos. ${ }^{12}$

Ademais, para entender a agência dos negros livres na região do Vallegrande, é pertinente também compreender o que era a região em si. Segundo Viedma, era formada por uma cadeia de montanhas, cortada por vales nos quais corriam muitos rios. Além dos diversos animais característicos da região - antas, veados, leopardos, javalis, entre outros -, as terras costumavam ser utilizadas para criação de gados e cultivo, principalmente, de cevada, trigo, amendoim e cana-de-açúcar destinados ao abastecimento de Potosí, La Paz e Puno. De acordo com o governador, entre os habitantes da região, haviam relatos de que os povoados teriam sido fundados inicialmente por negros fugidos das fazendas das cidades vizinhas, como Mizque..$^{13} \mathrm{Em}$ todo caso, havia no Vallengrande três povoados: ciudad de Jesús del Valle-grande, o "Chilon" e o "Samaypata" (VIEDMA, 1836, pp. 45-48). 14

Era diante desse cenário que as autoridades castelhanas decidiram intervir junto ao palenque formado por negros no Vallegrande. Na carta que pedia providências em 1786, estava afirmado que os negros que se encontravam na região, para além de atacarem as fazendas e chácaras vizinhas, haviam construído um forte e, frequentemente, faziam incursões a fim de seduzirem negros escravizados para fugirem: "(...) eles não somente fogem, como seduzem a outros escravos e escravas e roubam os atalhos mais floridos dos seus amos, reconduzem para aqueles lugares, de onde encontram acolhiada e amparo o que é visto" (DOC.1, fl.11). ${ }^{15}$

\footnotetext{
12 Segundo Rodas (1977, p. 26), entre os séculos XVI e XVII, o valor de um cativo poderia chegar em Buenos Aires a 300 pesos e em Charcas a 500 pesos. Por meio do contrabando barateava a 170 pesos.

13 Recentemente, Natan Weaver Oslon (2010) defendeu uma dissertação que reflete a fundação dos povoados da região à luz de diversas fontes, incluindo Viedma. Seguem nas referências os dados do trabalho.

${ }_{14}$ Vale ressaltar que Francisco de Viedma foi o primeiro governante-Intendente da Intendência de Santa Cruz, desde 1785. Para criação da Intendência, percorreu todo o território e elaborou um informe completo com ênfase em observações geográficas e econômicas, que destacavam a produtividade das regiões (HÁSBUN, 2003, p. 19).

15 "(...) ellos no solo the huyen, sino que seducienlo a otros esclavos y esclavas y roband lãs atajas mais floridas de suas amos, reconducen para aquelles lugares, em donde hallan La acolhida y amparo que esta visto" (DOC. 1., f.11).
} 
No documento, ainda se alertava que, caso não fossem tomadas providências imediatas, o palenque tenderia a aumentar. Era preciso não somente desfazer a reunião e capturá-los, mas punir todos os "vizinhos protetores" que amparavam e prestavam solidariedades aos negros fugidos. Um outro dado de grande relevância acompanhava o pedido de intervenção no Vallegrande: a liderança do agrupamento cabia a "negros portugueses":

(...) em ordem até exterminação dos baixios negros portugueses que são os que tem vindo a esta cidade os conduzir e os levam para aqueles onde já existem formada sua população. Segundo notícias positivas que sejam tomadas se baixas pessoas, de sorte que para fomentar e manter saqueiam e roubam as semeaduras e as fazendas (sic.) prejudicando deste modo a tanto a República que lamentam esse estrago [tradução nossa] (DOC.1, f.11v). ${ }^{16}$

A bandeira, então, foi autorizada por autoridades de La Plata e um efetivo de soldados foi enviado à região do Vallegrande. Entre os capturados, vários apareceram identificados como "emigrados de Portugal", como os irmãos Lorenzo Chavez e Ignacio. Conforme o interrogatório transcorreu, foi apurado que ambos eram africanos, oriundos da costa da Mina, e haviam fugido das minas do Cuiabá. Adentraram os domínios da Espanha pelos Chiquitos e, posteriormente, passaram ao Vallegrande.

Vale frisar que, embora a palavra "chiquitos" (pequeno) fosse referência a grupos indígenas que estavam espacializados entre o Chaco Boreal e nas selvas pantanosas, a partir do século XVII, passou a designar igualmente o conjunto de povoados na parte oriental do Alto Peru, formados a partir de antigas missões jesuíticas edificadas no período. De um total de dez missões fundadas com apoio da coroa, as que mais mantiveram contatos com a Capitania do Mato Grosso foram as missões de San Ignacio, Santa Ana, San Rafael e San Miguel. Nelas, plantava-se milho, algodão e havia consumo de produtos trazidos de Santa Cruz de la Sierra. Segundo Anzai, o acesso de sertanistas do território luso-brasileiro ao longo da história era relativamente fácil, de modo que a própria Cuiabá, em momentos de crise de abastecimento, tentou abrir um caminho aos Chiquitos para abastecer-se com gado vacum, cavalar e tecidos. Com a expulsão dos jesuítas dos

\footnotetext{
${ }^{16}$ Texto original: (...) em orden ala exterminacion de baxios negros portugueses que son los que aun biniendo a esta ciuidad los condusen y los llevan quellos donde existen ya formado su poblacion. Segun noticias pocitibas que Sean tomado se baxias perzonas, desuerse que para fomentarse y mantenerse saquean y roban las sementeras y panados e las haciendas cabenzias, prejudicando de este modo a tanto a Republica que lamentan este estrago (...) [grifo nosso] (Doc., f.11v).
} 
domínios espanhóis em 1767, acredita-se que os contatos e trânsito entre o Mato Grosso e o oriente boliviano tenham se intensificado em forma de contrabando (ANZAI, 2005). ${ }^{17}$

Em vista das fugas noticiadas junto aos arquivos luso-brasileiros, tudo leva a crer que uma parte considerável das fugas perpetradas por cativos de Cuiabá se dava através dos rios, conforme podemos observar no mapa que segue:

\section{Mapa: "Mappa de Cuiaba, Matogrosso y pueblos delos indios Chiquitos y Santa Cruz"}

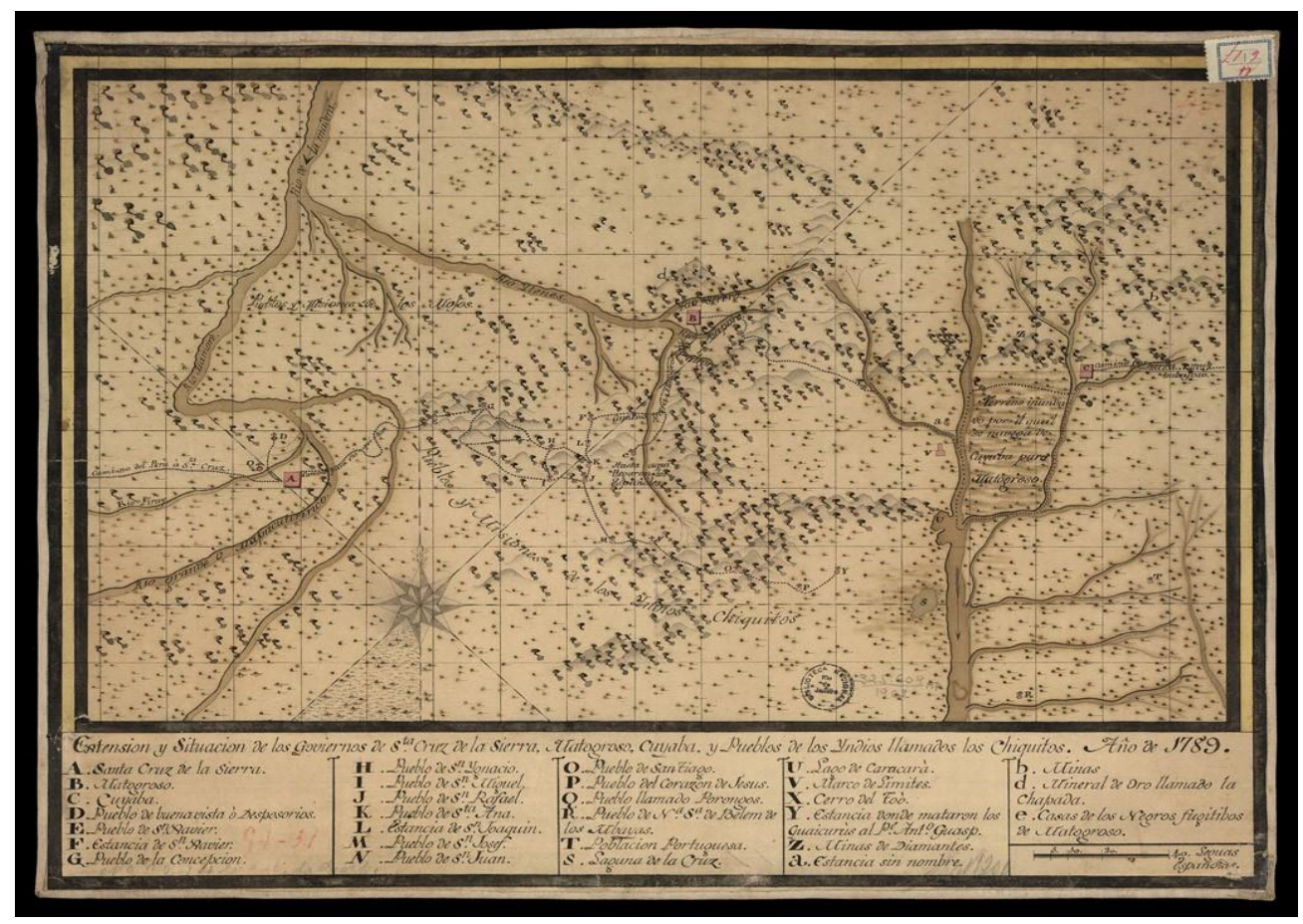

Fonte: Autor desconhecido. Disponível em <http://bndigital.bn.br/acervo-digital>. Acesso em 15 jan. 2015.

O mapa, elaborado no último quartel do século XVIII, indica com a letra $\mathrm{C}$, à direita, a vila de Cuiabá. Seguindo a direção Sul por via-fluvial, chega-se na fronteira com a América espanhola e, depois, por terra, na direção Oeste, gradualmente aos diferentes núcleos fundados em terras chiquitanas. Muito provavelmente esse tenha sido também o caminho tomado por um grupo de escravizados que, no ano de 1772, após matarem o Tenente de Auxiliares Manoel José Pinto no seu engenho, pegaram uma canoa, suprimentos, e seguiram rumo aos domínios espanhóis pelo rio Cuiabá. O Capitão-General de Mato Grosso, na sequência, formou uma pequena expedição com o fim de capturar os fugitivos, mas, segundo consta nos Anais de Cuiabá, não obteve sucesso porque o grupo tinha a seu favor uma noite e um dia de marcha (SUZUKI, 2007, p.101).

\footnotetext{
${ }^{17}$ Um episódio relatado nos Anais de Vila Bela de Santíssima Trindade corrobora com essa afirmação. O documento aponta que em 1776 a atuação de contrabandistas se dava com a travessia da fronteira com mulas para trocarem por cativos. Como a mão-de-obra cativa era considerada de primeira necessidade no Mato Grosso, afirma-se que tornou as punições mais rígidas a quem fosse flagrado comerciando com espanhóis (ANZAI; AMADO, 2006, p. 204)
} 
Voltando o foco ao palenque do Vallegrande, não deixa de chamar a atenção a "proteção" oferecida pelos "vizinhos", que certamente poderiam ser proprietários de fazendas ou empreendimentos da região. Ignacio, um dos capturados, no interrogatório, declarou exercer o ofício de peão. Outros poderiam estar integrados a atividades agrícolas. Levando em consideração as observações de Viedma acerca do cultivo da cana-de-açúcar em Santa Cruz de la Sierra e arredores, não estaríamos diante de um fato isolado. Segundo o governador intendente, o sucesso do cultivo da cana na região se devia, principalmente, a negros fugidos dos domínios de Portugal, que, devido a técnicas aplicadas, possibilitavam que o solo sempre estivesse fértil para o sucesso da cultura canavieira (VIEDMA, 1836, p. $66)$.

Ou seja, os negros que viviam na região do Vallegrande, ao passo que causavam temores e incômodos a uns, eram acolhidos e tolerados por outros; o que denota uma complexa tessitura de alianças para manutenção da condição livre na região. Caso a denúncia seja condizente com a realidade, fica evidente o cálculo equivocado em torno da capacidade dos grupos senhoriais de reagir à expansão da presença negra livre. Especulamos isso porque a acusação de que estivessem assediando e seduzindo outros negros escravizados poderia não ser real, mas sim objeto de temor de que a circulação de negros livres pudesse estimular os que eram mantidos no cativeiro a questionarem os grilhões.

O inquérito em torno do palenque do Vallegrande foi finalizado com o envio de correspondências às autoridades da Capitania de Mato Grosso, solicitando que identificassem os fugitivos, objetivando devolvê-los à América portuguesa. Outras medidas também foram tomadas, conforme a carta escrita em 19 de agosto de 1786:

(...) respeito de acreditam este expediente que nos lugares de Santa Cruz, Vallegrande e outros da freguesia relacionada a Cochabamba, se refugia negros fugidos do reino de Portugal e desta cidade com grande prejuízo a seus donos, de (sic) ofício aos governantes intendentes da Província para que tome as providências mais sérias e propícias para que em seu distrito não se permita vagar livremente nenhum negro e os que assim se encontrarem sejam segurados e remetidos a seus donos castigando aos desertores com as penas que le (sic) restituição e zelo, e sejam conformes [tradução nossa] [grifo nosso] (DOC.1, f.11v). ${ }^{18}$

\footnotetext{
18 (...)Respecto de acreditan este expediente que em los lugares de Santa Cruz, Vallegrande y otros de La freguesia relacionada de Cochabamba, se refugian los negros prófugos del Reino de Portugal y de esta ciudade com grande prejuicio de sus duenos, de (sic) oficio a los gobiernntes intendentes de La Provincia para que tome las providencias mas serias y condusentes a que em su distrito no se permita vagar libremente ningun negro y los que assi de encontraren sean asegurrados y remetidos sus duenos castigando a los desertores com las penas q Le (sic) restituto y zelo, y sean conformes [grifo nosso] (DOC., f.11v).
} 
Por certo, a proibição em torno da circulação de negros na região não obteve êxito nos anos seguintes. Além disso, cabe salientar que o contato entre as autoridades ibéricas em torno da questão escravista ao longo dos séculos XVIII e XIX foi objeto de numerosas idas e vindas. As correspondências enviadas pelo governador do Mato Grosso no final dos anos 1760, Luiz Pinto, ilustram isso. O governador alertava às autoridades de Santa Cruz de la Sierra sobre a entrada de escravizados fugidos do Mato Grosso nos domínios espanhóis via-missões jesuítas. Rogava, em nome de acordos firmados entre as coroas portuguesa e espanhola, que negasse asilo e devolvesse os que conseguisse identificar (Doc. 2). ${ }^{19}$

Apesar dos apelos das autoridades do Mato Grosso, as fugas seguiram século adentro. Ainda no ano de 1771, os Anais de Vila Bela informam um fato incomum: três cativos fogem do Mato Grosso rumo às missões dos Moxos. Para capturá-los, os soldados precisam atravessar a fronteira e, surpreendentemente, as autoridades do Mato Grosso ordenam o retorno dos cativos aos Moxos, para que fossem devolvidos formalmente pelas autoridades espanholas e, assim, a "amizade e benevolência" fossem preservadas entre as coroas (AMADO; ANZAI, 2006, p. 185).

Os próprios Anais de Vila Bela noticiam que, no de 1772, houve uma grande devolução de negros que haviam fugido para os domínios espanhóis:

(...) Por virtude desse decreto e de outras admiradas providências, que a respeito foi servido dar o sobredito Senhor Luís Pinto, no dia 29 de dezembro teve o povo grande contentamento de ver entrar, pelas ruas desta Vila, um cordão de 56 escravos, de um e outro sexo, debaixo de guarda e acorrentados, que imediatamente se distribuíram por seus donos, pagando cada um pro rata a despesa que lhe tocou, que ao todo montou de mais de mil oitavas (AMADO; ANZAI, 2006, p. 185).

Já sob o governo de Luiz Albuquerque, nos anos 1770 e 1780, igualmente observamos a articulação entre as autoridades ibéricas para captura e devolução de cativos. Especialmente em 1773, o então governador emitiu um bando que comemorava o êxito nas negociações e pedia que os moradores levassem ao Juiz de Fora da Vila de Cuiabá informações que indicassem sinais, idade, nomes e outras informações relativas aos negros fugidos (RAPMT, 1987, p. 40). No mesmo ano, Luiz Albuquerque chegou até mesmo a escrever ao Capitão General da Capitania de São Paulo para que ajudasse na restituição de cativos fugidos do Mato Grosso a outros destinos, como Assunção e

\footnotetext{
19 Vale frisar que, no período, a área designada pelo nome de Moxos, nordeste da atual Bolívia, estava inserida na Intendência de Santa Cruz, que contava também com os Chiquitos, Cordillera, Vallegrande e a própria Santa Cruz de la Sierra (HÁSBUN, 2014, p. 1).
} 
Tucumán, respectivamente cidades localizadas hodiernamente no Paraguai e Argentina (Doc. 3, f. 149).

Em suma, o processo disponível sobre o palenque do Vallegrande finda exatamente neste ponto, de modo que não sabemos, até o atual momento, se os negros livres capturados na expedição organizada pelas autoridades espanholas foram, de fato, enviados ao Mato Grosso, se permaneceram em cárcere ou se foram libertados. Talvez, em vista do caráter fragmentário das fontes, nunca saibamos a continuidade das histórias de Lorenzo Chavez, Ignacio e seus companheiros.

Indiscutivelmente, as últimas décadas têm permitido a revisão de diversos aspectos das vidas dos homens e mulheres que viveram a escravidão do mundo moderno. Sob influência direta da chamada história social, cultural, estudos subalternos, emprego de arcabouços teóricos de áreas afins e provocados pelos debates em torno das teorias póscoloniais e decoloniais, tem sido possível perscrutar esses indivíduos de forma dinâmica e não-essencializada, como agentes e protagonistas das suas vidas e tempo. ${ }^{20}$ É mais do que necessário visualizar, ouvir e lançar luz sobre sujeitos negligenciados e subalternizados, a fim de que possamos construir uma visão democrática do processo histórico. A análise das estratégias empregadas para manutenção da liberdade no interior dos quilombos, palenques ou marrons, é um caminho especial para concretizar essas aspirações, pois, onde quer que a escravidão negra tenha sido implementada, homens e mulheres lançaram mão de todos os meios disponíveis para uma vida além dos grilhões e, quando a ruptura definitiva não era condição real, se valeram de estratégias para amenizar o peso da escravidão. Chegamos ao término desta reflexão com mais indagações do que respostas, mas com o desejo de que novos pesquisadores possam seguir os rastros daqueles que, mesmo empurrados para as margens, friccionaram e romperam o silêncio.

\section{Referências}

\section{Fontes primárias}

Doc. 1 - ABNB, MyCh, sobre escravos minas na Bolívia, 1786, Cx. 195-10.

Doc. 2 - APMT, Manuscritos, Estante 1, C-04, 1769.

Doc. 3 - APMT, Manuscritos, Estante 1, C-07, 11 de junho de 1773.

\footnotetext{
${ }^{20}$ No que tange à história social, fazemos alusão principalmente aos trabalhos de Edward Thompson (1987). Sobre os estudos subalternos, recomendamos o balanço realizado por David Ludden (2002). Acerca dos estudos pós-coloniais e decoloniais, sugerimos a leitura de Bernadino-Costa e Grossfoguel (2016). Finalmente, no que se refere ao empréstimo de arcabouços conceituais e metodológicos, especialmente as ideias de fricção étnica e etnogênese, indicamos o estudo de Roberto Cardoso de Oliveira (1969) e Fontella (2020).
} 


\section{Fontes publicadas}

AMADO, Janaina; ANZAI, Leny Caselli. Anais de Vila Bela (1734-1789). Cuiabá: Carlini \& Caniato: EdUFMT, 2006.

RAPMT, "Carta de Luiz de Albuquerque - bando de 10 de janeiro de 1773". Vol. 1, n.3, março/setembro de 1987.

SUZUKI, Yumiko Takamoto. Annaes do Sennado da Camara do Cuyabá (1719-1830). Transcrição e organização Yumiko Takamoto Suzuki Cuiabá:Entrelinhas/Arquivo Público de Mato Grosso, 2007.

VIEDMA, Francisco de. Descripcion Geografica y estadística de la Provincia de Santa Cruz de la Sierra. $1 \stackrel{\text { a }}{ }$ ed. Buenos Aires: Imprenta del Estado, 1836.

\section{Livros, artigos, teses e dissertações}

ANDREWS, George Reid. América afro-latina, 1800-2000. Tradução de Magda Lopes. São Carlos: Ed. UFSCAR, 2007.

ANTONIL, 'Cultura e opulência do Brasil'. Belo Horizonte: Itatiaia, 1982.

BERNARDINO-COSTA, Joaze; GROSSFOGUEL, Ramón. Decolonialidade e perspectiva negra. Revista Sociedade e Estado, v. 31, n. 1, jan/abril. 2016.

BOWSER, Frederick. "Los africanos en la sociedade de la America española colonial. In: BETTHEL, Leslie (org.) Historia da America Latina, tomo IV. Barcelona: Crítica, 1990.

CARVALHO, Daniela Vallandro de. Em solos fronteiriços e movediços: fugas cativas em tempos beliciosos (Província de São Pedro,século XIX). In: GRINBERG, Keila (Org.) As fronteiras da escravidão e da liberdade no sul da América. Rio de Janeiro: 7Letras, 2013.

FLORES, Mariana Flores da Cunha Thompson. Os sedutores de escravos: a ação de sedutores nas fugas de escravos pela fronteira meridional do Brasil, 1845-1889. In: GRINBERG, Keila (Org.) As fronteiras da escravidão e da liberdade no sul da América. Rio de Janeiro: 7Letras, 2013.

FONTELLA, Leandro Goya. O conceito de etnogênese: o dinamismo histórico das identidades coletivas. História: debates e tendências, Passo Fundo, v. 20, n.1, jan/abr 2020.

GUIMARÃES, Carlos Magno. "Mineração, quilombos e Palmares - minas gerais no século XVIII". In: GOMES, Flávio dos Santos; REIS, João José (Orgs.). Liberdade por um fio: história dos quilombos no Brasil. São Paulo: Companhia das Letras, 1996, pp.139-154.

HASBÚN, Paula Peña. La Permanente construcción de lo cruceño: un estúdio sobre la identidad en Santa Cruz de la Sierra. La Paz: FUNDACIÓN PIEB, 2003

. HASBÚN, Paula Peña. La guerra de Independencia en Santa Cruz, 2014.

LARA, Silvia Hunold. "Do singular ao plural: Palmares, capitães do Mato e o governo dos escravos". In: REIS, João José; GOMES, Flávio dos Santos (Orgs.). Liberdade por um fio: história dos quilombos no Brasil. São Paulo: Companhia das Letras, 1996. 
LORDELO, Monique. Indígenas, escravizados negros e homens livres na fronteira do Mato Grosso, Bolívia e Paraguai: fugas, contrabando e resistência (1750-1850). Universidade de São Paulo, Faculdade de Filosofia, Letras e Ciências Humanas, 2019 (tese).

LUDDEN, David. "A brief history of Subalternity". In: LUDDEN, David (Org.). Reading Subaltern Studies: Critical History, Contested Meaning and the Globalisation of South Asia. London: Anthem South Asian Studies, 2002.

OLIVEIRA, Roberto Cardoso de; FARIA, L. de Castro. O contato interétnico e o estudo de populações. Revista de Antropologia, v. 17-20, 1969.

OSLON, Nathan Weaver. Pardos in Vallegrande: an exploration of the role of afromestizos in the foundation of Vallegrande, Santa Cruz, Bolivia. San Diego, University of California, 2010 (dissertação).

PRICE, Richard. Palmares como poderia ter sido. In: GOMES, Flávio dos Santos; REIS, João José (Orgs.). Liberdade por um fio: história dos quilombos no Brasil. São Paulo: Companhia das Letras, 1996.

Rodrigues, Bruno Pinheiro. "El fuego de la libertad": a conspiração sufocada de negros livres, cativos fugidos da América portuguesa e indígenas em Santa Cruz de La Sierra (1809). Revista Eletrônica Da ANPHLAC, (20), 197-221, $2016 a$.

RODRIGUES, Bruno Pinheiro. O trânsito de cativos do oeste da América portuguesa para espanhola: fugas, sequestros e a busca por liberdade (século XVIII). Fronteiras: Revista de História, Dourados-MS, v. 18, n. 31, pp.357-374, jan/jun. 2016b.

RODAS, Alberto Crespo. Esclavos negros em Bolivia. La Paz: Academia Nacional de Ciencias de Bolivia, 1977.

SECRETO, Maria Verónica. "Soltando-se das mãos: liberdades dos escravos na América espanhola". In: AZEVEDO, Cecília; RAMINELLI, Ronald. História das Américas: novas perspectivas. Rio de Janeiro: Editora FGV, 2011.

SENA, Ernesto Cerveira de. SENA, Ernesto. Fugas e reescravizações em região fronteiriça - Bolívia e Brasil nas primeiras décadas dos Estados nacionais. In: Estudos IberoAmericanos, v. 39, n. 1, pp. 82-98, 2013.

SORIA, Esther. El mulato Francisco Rios: líder y plebe (25 de mayo de 1809 - noviembre de 1810). In: BONILLA, Heraclio (org.). Indios, negros y mestizos en la independência. Bogotá: Editorial Planeta Colombiana S. A., 2010

THOMPSON, Edward. A formação da classe operária inglesa, Vol. I, II, e III. 2 ${ }^{\mathrm{a}}$ ed. Tradução de Renato Busatto Neto e Cláudia Rocha de Almeida. Rio de Janeiro: Paz e Terra, 1987.

THORTON, John. A África e os africanos na formação do Novo Mundo, 1400-1800. Tradução de Marisa Rocha Mota. Rio de Janeiro: Elsevier, 2004. 


\section{A IDENTIDADE QUILOMBOLA E OS REMANESCENTES FORA DO TERRITÓRIO: UMA REALIDADE DA COMUNIDADE ABOLICÃO E DE TANTAS OUTRAS}

\section{CLÉIA BATISTA DA SILVA MELO²1}

Este texto propõe reflexões acerca dos remanescentes quilombolas que vivem fora de seus territórios sob o ponto de vista da luta das comunidades quilombolas pelo reconhecimento de suas ancestralidades, histórias, contribuições e reparações de direitos, sobretudo, o direito sobre a terra.

A luta dos remanescentes que se encontram fora de seus territórios é uma luta ainda mais árdua, pois a Constituição Federal de 1988, em seu art. 68, é clara em afirmar que o direito do remanescente só é possivel se estiver ocupando o território. Dessa forma, fica a pergunta: mas e os que por diversos motivos tiveram de sair de seus territórios? A eles, não resta nenhum direito sobre a terra?

A pesquisa foi desenvolvida na Comunidade Quilombola de Abolição, cujo território corresponde a cerca de 13.400 ha. Essa comunidade está localizada no município de Santo Antônio do Leverger, a 60km da capital Cuiabá, em Mato Grosso.

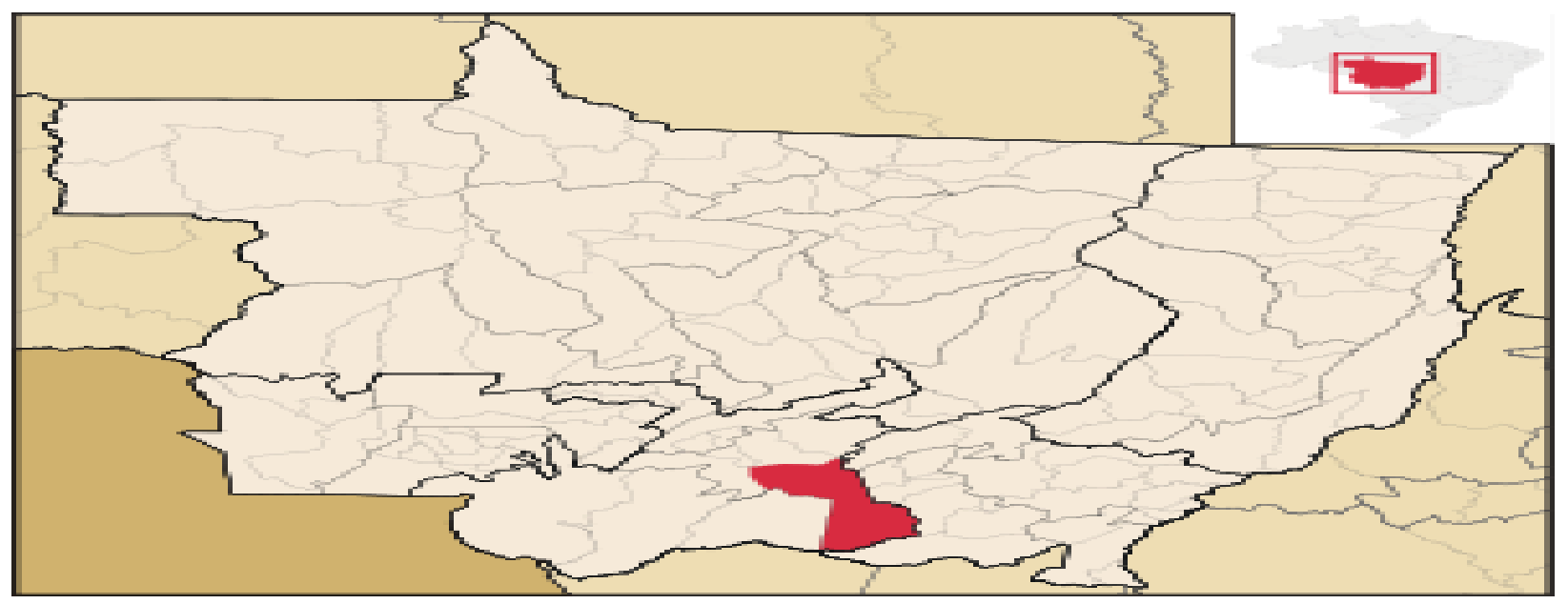

Fonte: https://www.leverger.mt.gov.br/. Acesso em 10 de setembro de 2020. Em destaque o município de Santo Antônio do Leverger.

De acordo com a análise desenvolvida e a aplicação do questionário prosopográfico na Comunidade Quilombola de Abolição, foi constatado que um número significativo de famílias está fora do território. Esse fenômeno pode ser mais comum do que imaginamos, porém, são raros os estudos, pesquisa ou referencial teórico sob esse enfoque. Sendo

${ }^{21}$ Mestre em História pela Universidade Federal de Mato Grosso. Especialista em Metodologia do Ensino de História. Professora da Rede Estadual de Ensino. Membro do Grupo de Pesquisa EPIFAN. 
assim, propomos novos estudos a esse respeito e que eles venham contribuir, também, para que possamos levantar discussões e reflexões sobre sujeitos que possuem ancestralidades, memórias e histórias vinculadas à terra, mas que, infelizmente, não estão resguardados pela legislação porque se encontram fora do território.

As comunidades quilombolas brasileiras ganharam visibilidade do poder público e legalidade com a Constituição Federal de 1988. A partir de então, são garantidos direitos territoriais aos remanescentes quilombolas, desde que estejam ocupando efetivamente a terra. O’Dwyer corrobora essa afirmação ao dizer que "é preciso, sobretudo, que esses sujeitos históricos presumíveis existam no presente e tenham como condição básica o fato de ocupar uma terra que, por direito, deverá ser em seu nome titulada"22.

Analisando essa exigência da legislação brasileira, podemos indagar se a obrigatoriedade de ocupação do território é uma exigência justa, considerando o ponto de vista das inúmeras circunstâncias que dificultam a permanência dos remanescentes quilombolas em seus territórios - desde condições difíceis de sobrevivência, como falta de atendimento de saúde, falta de incentivo governamental para o trabalho e o cultivo da terra, até interferências externas, como os conflitos com fazendeiros e grileiros. Por esses motivos, devemos refletir sobre os remanescentes que tiveram de sair de seus territórios, mas que ainda mantêm o vínculo com os que ficaram e possuem histórias e memórias ligadas à ancestralidade negra que fincou raízes naquela terra por séculos. Podemos, então, questionar: a legislação está sendo excludente ao exigir a permanência dos remanescentes no território? É excludente quando não leva em consideração as dificuldades da permanência e os motivos que levaram essas pessoas a abandonarem suas terras?

Essas indagações deveriam ser feitas durante as pesquisas e análises realizadas pelos órgãos governamentais, ONGS e pesquisadores, para identificar os reais motivos que afastaram os remanescentes de seus territórios e os possíveis interesses de retornar para eles.

É necessário que órgãos governamentais e, inclusive, pesquisadores tenham um olhar mais direcionado para essas questões, uma vez que, dessa forma, talvez possamos compreender a dinâmica social e a relação dos remanescentes dentro e fora de seus territórios.

\footnotetext{
${ }^{22}$ O’DWYER, Eliane Cantarino (Org.) Quilombos: identidade étnica e territorialidade. Editora FGV. Rio de Janeiro. 2002.p.13
} 
Eliane O'Dwyer chama a atenção para essas amarras que ainda dificultam o processo de compreensão do ser quilombola, suas características, mudanças, transformações e necessidades de reconhecimento dentro de suas diferenças:

(...) é necessário que nos libertemos da definição arqueológica, da definição histórica stricto sensu e das outras definições que estão frigorificadas e funcionam como uma camisa de força, ou seja, da definição jurídica dos períodos colonial e imperial e até daquela que a legislação republicana não produziu, por achar que tinha encerrado o problema com a abolição da escravatura, e que ficou no desvão das entrelinhas dos textos jurídicos.

( O’DWYER, 2002. p.22-23)

Dessa forma, torna-se evidente a necessidade de refletir sobre o significado da territorialidade e do ser quilombola, assim como é necessária a elaboração de políticas públicas que venham a garantir direitos aos remanescentes - mesmos aqueles que, por motivos diversos, foram obrigados a sair de seus territórios. Precisamos levar em consideração que as comunidades quilombolas e seus remanescentes não são os mesmos nem iguais aos do passado; passaram por processos de mudanças, reoorganização e reconstrução da identidade étnica quilombola. Contudo, ainda possuem o vínculo com a terra dentro ou fora do território, possuem ancestralidades vinculadas à população africana e afro-brasileira que vivenciaram o processo escravocrata, histórias e memórias que precisam ser respeitadas, valorizadas, legitimadas e reparadas dentro do processo legal.

Nessa perspectiva, a pesquisa na Comunidade Quilombola Abolição levantou exatamente tal problemática. Cerca de 140 famílias remanescentes daquele território encontram-se morando fora da terra, no perímetro rural e urbano de Santo Antônio de Leverger, Várzea Grande e, principalmente, Cuiabá. Uma pequena parcela resiste, permanecendo no território, mesmo que às margens das estradas ou beiradeando as cercas das grandes fazendas, contabilizando aproximadamente 22 famílias. É preciso considerar o fluxo de mobilidade de algumas dessas famílias, pois ora estão no território, ora estão fora dele; então, esse número pode sofrer pequena alteração em determinado período.

Além do caráter observatório, a pesquisa desenvolvida nessa comunidade também realizou uma pesqusia prosopográfica, ${ }^{23}$ aplicada a 30 pessoas que se autodefiniram

\footnotetext{
${ }^{23}$ A prosopografia, segundo Stone, é a investigação das características comuns do passado de um grupo de atores na história através do estudo coletivo de suas vidas. O método empregado é o de estabelecer o universo a ser estudado e formular um conjunto uniforme de questões - sobre nascimento e morte, casamento e família, origens sociais e posições econômicas herdadas, lugar de residência, educação, tamanho e origens das fortunas pessoais, ocupação, religião, experiência profissional etc. Os vários tipos de informação sobre indivíduos de um dado universo são, então, justapostos e combinados e, em seguida, examinados por meio de variáveis significativas. Essas são testadas a partir de suas correlações internas e correlacionadas com
} 
remanescentes quilombolas da Comunidade Abolição. Entre elas, estão 11 pessoas que nasceram e ainda vivem naquele território e 19 pessoas que nasceram lá, mas tiveram de sair da terra por fatores diversos como: estudo dos filhos, busca por emprego, questões de saúde, dificuldades para viver da produção da terra e, inclusive, por motivos de conflito e de pressão - no caso da venda ilegal da terra por preços baixíssimos após pessoas malintencionadas persuadirem senhores e senhoras de idade e com pouca instrução a saírem da terra por um valor simbólico alegando que a terra de nada valia.

A imagem abaixo foi feita na Comunidade Quilombola Abolição, em dezembro de 2019, durante uma das visitas, observações e aplicação do questionário prosopográfico. A senhora da foto se chama Maria Lúcia da Silva Magalhães, 64 anos, uma das remanescentes que nasceu e viveu até a adolescência na comunidade. Depois, precisou ir para a capital estudar e, já na vida adulta, regressou ao seu território.

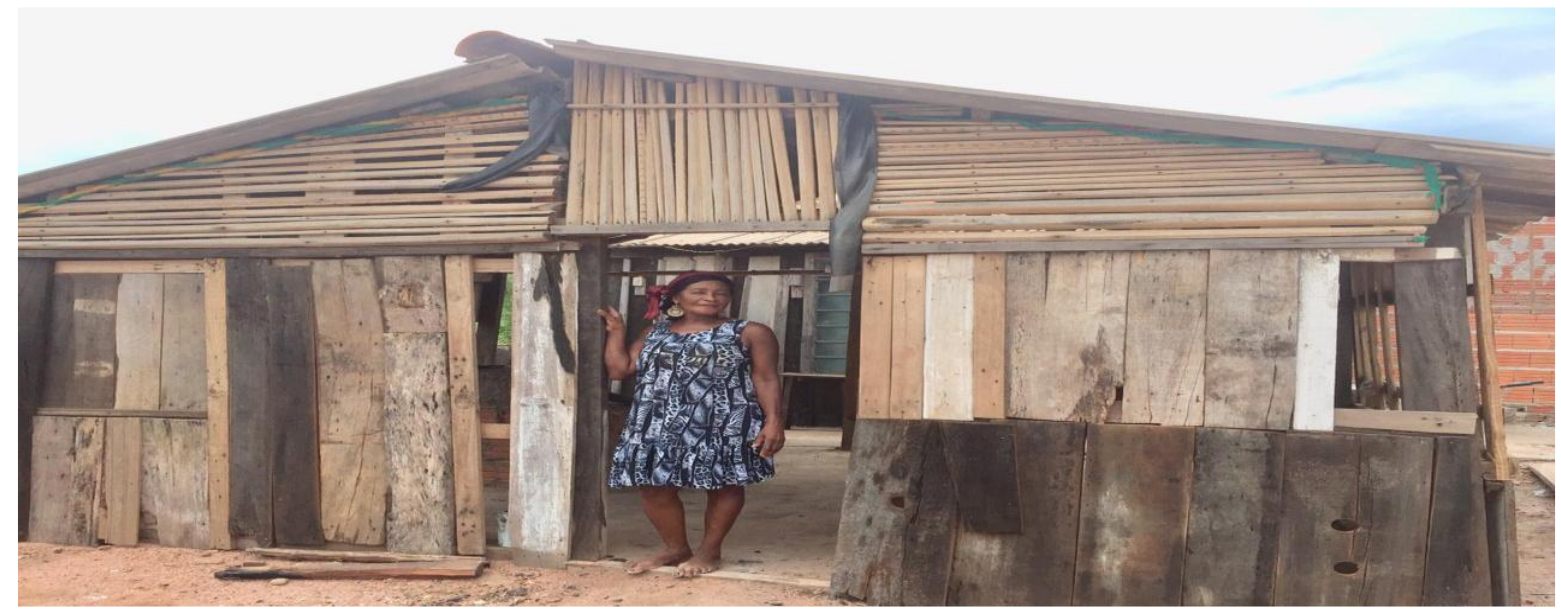

Fonte: acervo pessoal. Dezembro de 2019

Sua casa, como da maioria dos remanescentes que ainda estão na terra, situa-se hoje na vila chamada Vila Nova, às margens de uma estrada vicinal, fora das cercas das fazendas que percorrem a estrada. A vila surgiu a partir de uma expulsão do local denominado Pedreira, onde muitas dessas famílias viviam há anos, dentro do território quilombola de Abolição. Essa expulsão "ocorreu em 2011, onde essas famílias foram removidas da Pedreira sob alegação de pertencer a empresa ENCO". ${ }^{24}$

Desde 2011, a Associação dos Remanescentes Quilombolas de Abolição vem lutando para a suspensão das atividades dessa empresa no território quilombola, já que a

outras formas de comportamento e ação. (STONE, Laurence. Prosopography. In: Daedalus: journal of American Academy of Arts and Sciences, vol. 100, no 1, 1971, p.76)

24 INCRA- Instituto Nacional de Colonização e Reforma Agrária. Relatório de Caracterização histórica, econômica, ambiental e sociocultural: território quilombola Abolição. Processo n54240.005251/2005-08 Cuiabá, 2019.p.09 
extração de pedras britadas causa grande impacto ao ambiente. Além disso, reivindicam o retorno à terra da qual foram expulsos. Somente agora, em 2020, o Ministério Público Federal recomendou, à Secretaria de Estado do Meio Ambiente (SEMA), a suspensão das atividades da empresa Enco naquele território.

A recomendação é resultado do Inquérito Civil n. 1.20.000.000564/2015-99, instaurado com o objetivo de averiguar possível usurpação de parte do território da Comunidade de Remanescentes de Quilombolas do Quilombo Abolição, em Santo Antônio do Leverger. Busca-se assegurar-Ihes o pleno e livre exercício da posse de seu território, ameaçada por atos tendentes a excluí-la do poder físico sobre o bem, de modo a permitir a finalização do processo administrativo n. 54240.005251/2005-08 do Incra, com a concessão de titulação de propriedade das terras originariamente ocupadas pela comunidade. ${ }^{25}$

A Associação aguarda a suspensão das atividades de mais duas empresas que exploram pedra britada dentro do território quilombola de Abolição.

A situação relatada anteriormente é mais uma prova de que vários fatores contribuem para que os remanescentes quilombolas abandonem suas terras, seja através da expulsão, seja através da persuasão para venderem a preço vil, pela dificuldade financeira, problemas de saúde, estudo dos filhos, entre outros. Porém, precisamos analisar essas situações como problemáticas que não dependem apenas do desejo e força de vontade das pessoas de permanecer em suas terras e em seus territórios.

A observação e a pesquisa prosopográfica realizada na Comunidade Quilombola Abolição nos levaram a refletir acerca dos direitos não só dos remanescentes que continuam no território quilombola, mas, também, daqueles que tiveram de abandonar suas terras para viver hoje em outros lugares e que ainda têm a esperança e o desejo de regressarem aos seus locais de vivência e pertencimento histórico, simbólico e de memória.

Embora essas pessoas tenham saído de seus territórios em determinado momento de suas vidas, ainda na infância ou na idade adulta, é necessário considerar o tempo de convivência coletiva, social, cultural e simbólica que fortalece os vínculos entre o passado e o presente. Um passado que está na memória viva dos remanescentes, na qual a simbologia, hábitos e práticas são elementos necessários para legitimar a história de uma ancestralidade que permanece viva no presente através dos herdeiros dos quilombos.

Desse modo, o fato de não estarem presentes fisicamente no território não significa que essas pessoas não sejam remanescentes quilombolas pertencentes àquela

\footnotetext{
${ }^{25}$ www.mpf.mp.br. MPF recomenda que Sema suspenda licença de pedreira em Santo Antônio de Leverger (MT). Publicado em 17 de março de 2020.
} 
comundiade e àquele território, pois carregam dentro de si todo aprendizado e vivência adquirida no tempo em que viveram naquela sociedade. Práticas, hábitos, culturas, saberes, aprendizados e todas as demais características que ligam tais remanescentes àquela ancestralidade, tornando-os pertencentes ao território étnico quilombola. Com isso, precisamos refletir acerca dos direitos materiais e imateriais desses agentes sociais, sobretudo, o direito à terra também para os que estão fora do território e que pretendem regressar a ele resguardados por seus direitos legais de posse e titulação.

Situação parecida é enfrentada por uma comunidade no município de Chapada dos Guimarães/MT, conhecida como Lagoinha de Cima, onde a maioria dos remanescentes estão fora do território. Como relata Sônia Lourenço:

A comunidade de Lagoinha de Cima conta com um total de 34 famílias. Entretanto, apenas dez permanecem no território tradicional, distribuídas em oito casas próximas umas das outras numa área dividida entre a parte arrendada e vendida de forma compulsória desde a década de 1970, quando da primeira ação de despejo. (...) Todas as famílias que residem fora do território tradicional aguardam a titulação destes para voltarem a viver "todos juntos". (LOURENÇO, 2016.p.112)

A condição vivida pela Comunidade Lagoinha de Cima assemelha-se com a realidade da Comunidade Abolição, uma vez que ambas apresentam uma população remanescente dividida entre os que estão no território e os que estão fora dele. Essa dualidade não exime o caráter de luta por direitos da parte de todos, pois, muitas vezes, o fato de se encontrar fora do território não representa o não pertencimento ou a ausência do desejo de reaver seu território. Tal característica decorre, na realidade, da necessidade de evasão por motivos que os afugentaram, como a expulsão relatada por alguns dos remanescentes que responderam ao questionário prosopográfico. Essa violência acontece em todas as partes do Brasil onde existem comunidades tradicionais. O cerceamento dessas terras ocorre há séculos sem que se tenha um olhar mais específico do poder público e da justiça.

A "fuga" para outros lugares fora dos seus territórios é uma forma de sobreviver, de se reinventar e, muitas vezes, ganhar fôlego e força para lutar e retornar. Como chamamos a atenção nesse texto, os remanescentes que estão fora dos seus territórios tradicionais também devem ter seus direitos garantidos, já que se autorreconhecem quilombolas e, por onde quer que vão, levam a marca identitária nos seus hábitos, costumes, tradições e memórias.

Uma pesquisa realizada pelo Antropólogo Emanuel de Almeida Júnior em uma comunidade quilombola do Amazonas também retrata essa realidade. O pesquisador 
destaca, inclusive, que os remanescentes da cidade utilizam técnicas tradicionais herdadas do quilombo para desenvolver práticas extrativistas:

Atualmente, a autodefinição como quilombola está referida tanto às famílias que residem na cidade quanto às famílias que residem na comunidade do Tambor, no rio Jaú. É oportuno observar que, até mesmo na cidade, as famílias quilombolas mantiveram seus sistemas tradicionais agrícolas, incluindo as práticas extrativistas, nos arredores do centro urbano. (JÚNIOR, 2016. p.60)

Assim como esses exemplos acima, a Coleção Terras de Quilombos, lançada em 2015, em uma parceria entre Incra, Ministério do Desenvolvimento Agrário (MDA) e Universidade Federal de Minas Gerais (UFMG), retratou também histórias de remanescentes que tiveram de sair dos seus territórios. Essa coleção tem o objetivo de reunir "narrativas a respeito da formação, do modo de vida e das lutas travadas por comunidades quilombolas brasileiras para se manterem em seus territórios tradicionais". ${ }^{26}$

Dentre essas narrativas que trazem a saída dos remanescentes de seus territórios, está a da Comunidade Quilombola do Amaro, na região de Paracatu, MG. Quem realizou a pesquisa nessa comunidade foi a antropóloga Ana Carolina Estrela da Costa, concluindo que "a dispersão dos Amaros por diferentes municípios deve-se, em grande parte, à ação dos fazendeiros, que foram expulsando as famílias das terras onde originalmente moravam". 27

A autora revela também que alguns herdeiros da família Amaro, a partir de 1960, "começaram a vender (sem documento de transferência legal de propriedade ou de posse) parte da terra ocupada durante mais de um século pela Comunidade Família dos Amaros."28

Assim como na Comunidade Quilombola Abolição, a persuasão e pressão dos grandes fazendeiros e empresas de mineradoras fizeram com que alguns remanescentes da Comunidade dos Amaros vendessem suas terras por valores diminutos.

Nesse sentido, a autora afirma que:

A partir dos anos de 1980 não só fazendeiros compraram as terras, mas também grandes mineradoras. As mineradoras também tentavam comprar direitos de posse diretamente dos Amaros (as últimas famílias dos Amaros que trabalhavam para os fazendeiros), ao mesmo tempo em que avançavam com as cercas sobre as lavouras. (ESTRELA, 2015.p.01)

\footnotetext{
${ }^{26}$ Coleção Terras de Quilombos. Incra, Ministério do Desenvolvimento Agrário (MDA) e Universidade Federal de Minas Gerais (UFMG). Belo Horizonte/MG, 2015.p.20

27 ESTRELA da Costa, Ana Carolina. Quilombo Amaros de Paracatu. Coleção Terras de Quilombos Belo Horizonte/MG: FAFICH, 2015.p. 01.

28 Idem. p. 05
} 
Iniciou-se, nesse momento, a luta dos demais remanescentes dos Amaros por suas terras. "Neste mesmo período em que fazendeiros e mineradoras compravam e apossavam das terras, foram localizados no Cartório a escritura e o inventário dos bens de Amaro Pereira das Mercês, comprovando que a Fazenda Pituba pertenceria à comunidade". ${ }^{29}$

Apesar dessa comprovação, a luta pelo reconhecimento perdurou por décadas e somente em 2004 foram reconhecidos pela Fundação Cultural Palmares e passaram "a ser protegidos pelas leis específicas que foram regulamentadas pela Constituição de 1988". 30

Utilizaremos aqui mais um exemplo de uma comunidade remanescente de quilombolas retratada, na Coleção Terras de Quilombos, pela pesquisadora Luciana Célia da Silva Costa.

A comunidade pesquisada é o Quilombo Cafundó, no município de Salto de Pirapora, estado de São Paulo. Segundo a pesquisadora:

Cafundó ficou conhecido no Brasil e o mundo nos anos 1970 ao ser noticiado que apenas lá se falava a cupópia, uma língua própria desenvolvida pelo grupo, que combina vocábulos africanos (principalmente quimbundo) e particularidades gramaticais do português caipira. (COSTA, 2015.p.01-02)

Essa comunidade, assim como tantas no Brasil, com suas peculiaridades e identidades próprias, passou décadas resistindo e lutando pelo reconhecimento de seus direitos. Entre essas lutas e resistências, estavam os embates com grileiros e fazendeiros da região, pois "as terras do Confundó e Caxambu passaram a ser cada vez mais cobiçadas por fazendeiros vizinhos que foram invadindo as áreas da comunidade". ${ }^{31}$

Essas invasões ocorreram por volta de 1940 e perduraram por décadas. "Desde a década de 1960 os moradores do Cafundó procuraram resistir a tomada de suas terras". ${ }^{32}$

Entre invasões, expulsões, evasões, lutas, resistências, violências e até mortes, somente em 2012, "após tanta luta e sacrifício o Incra regularizou parte das terras do quilombo". 33

Todas essas narrativas nos levam a refletir sobre as dificuldades enfrentadas pelos remanescentes quilombolas para permanecerem em seus territórios, pois, infelizmente, essas pessoas possuem mais motivos para abandonar suas terras do que para permanecer nelas. Os principais motivos são desde pressão, medo e violência, até a morosidade da justiça e abandono por parte do poder público. Contudo, apesar de todos esses entraves,

\footnotetext{
29 lbidem p. 06

30 lbidem. p.08

31 Idem. p. 05

32 Ibidem.p. 09

33 Ibidem.p. 11
} 
muitos resistem, lutam e acreditam na importância das suas ancestralidades, identidades e territorialidades.

\section{A territorialidade quilombola}

A organização do espaço onde se desenvolvem economias, políticas, sociedades e culturas é o território. Organização essa que remonta aos tempos das organizações dos primeiros quilombos lá pelos idos dos séculos $\mathrm{XVI}$, onde os aquilombados dentro dos seus territórios formados construíam a territorialidade do grupo, com seus saberes e fazeres. Essa organização do território se dá por meio das relações sociais que se constituem no espaço; relações simbólicas, políticas, culturais e de poder que delineiam os interesses e objetivos do grupo. Poder político e poder simbólico caminham juntos, como chama a atenção Haesbaert:

O poder não pode de maneira alguma ficar restrito a uma leitura materialista, com se pudesse ser devidamente localizado e "objetificado". Num sentido também aqui relacional, o poder com relação, e não com coisa a qual possuímos ou da qual somos expropriados, envolve não apenas as relações sócias concretas, mas também as representações que elas veiculam e, de certa forma, também produzem. Assim, não há como separar o poder político num sentido mais estrito e poder simbólico. (HAESBAERT, 2007.p. 93)

Podemos pensar que a territorialidade quilombola está relacionada a tudo o que aquele espaço de vivências comuns em grupo representa simbolicamente, culturalmente, socialmente e historicamente para os seus agentes, trazendo, da ancestralidade aos dias atuais, a dinâmica de construção, reconstrução e fortalecimento da identidade dos herdeiros dos quilombos.

Todos esses atos e significados marcam a territorialidade de um povo, suas características, objetivos e vivências, culminando na construção de um território próprio, pois, segundo Little, "a territorialidade é o esforço coletivo de um grupo social para ocupar, usar, controlar e se identificar com uma parcela específica de seu ambiente biofísico, convertendo-a assim em seu território"34.

Percebemos que a ocupação do território e a demarcação da territorialidade fazem parte da construção identitária de um povo. Contudo, precisamos atentar para o fato de que essa ocupação pode ser temporária, móvel e dinâmica, pois, no caso dos remanescentes

\footnotetext{
34 LITTLE, Paul E. "Territórios Sociais e Povos Tradicionais no Brasil. Por uma antropologia da territorialidade", Anuário Antropológico/2002-2003. Rio de Janeiro: Tempo Brasileiro, 2004. p. 253
} 
quilombolas de Abolição, a movimentação dentro e fora do território sempre existiu e continua existindo. Ora, algumas famílias saem do território para trabalhar em fazendas vizinhas ou mais distante, mas mantêm o vínculo com a terra; sempre que podem, estão ali cuidando, visitando familiares e, inclusive, cultivando alimentos. Em outros casos, mudam para a cidade buscando melhores condições de vida, como emprego, escola para os filhos e tratamento de saúde. Ainda assim, continuam se relacionando com a comunidade e suas atividades simbólicas, culturais, religiosas e sociais, participando das reuniões da Associação Quilombola, por exemplo.

Ao se mudarem temporariamente, muitos remanescentes deixam a terra aos cuidados de familiares da comunidade ou, muitas vezes, voltam nos finais de semana para cuidar e cultivar para, inclusive, ajudar nas despesas. Alguns conseguem regressar depois de certo tempo e continuar a vida na terra e na coletividade. Outros, porém, não têm a mesma sorte, pois, em muitos casos, a terra já foi invadida ou redemarcada e cercada pelos fazendeiros da região. Sendo assim, mesmo longe ou não fixados fisicamente por um tempo contínuo e imóvel, esses remanescentes viveram e participaram da construção dessa identidade por um determinado tempo, possuindo vínculos familiares, históricos, simbólicos e de resistência. Tais vínculos os tornam pertencentes e asseguram, assim, sua autodeclaração como remanescentes quilombolas. Esses fatores precisam ser levados em consideração quanto às questões que garantem os direitos legais aos quilombolas, não somente para aqueles que estão ocupando o território, mas também para aqueles que já ocuparam, que marcaram ali suas histórias e que desejam regressar.

O ser remanescente e o conceito de quilombo vêm há muitos anos ganhando novas formas devido exatamente às dinâmicas de transformações no modo de ser, viver e pensar de seus indivíduos. Segundo Eliane O’Dwyer, em um documento elaborado em 1994 pelo Grupo de Trabalho da ABA sobre Terra de Quilombo,

(...) o termo quilombo tem assumido novos significados na literatura especializada e também para grupos, indivíduos e organizações. Ainda que tenha um conteúdo histórico, o mesmo vem sendo 'ressemantizado' para designar a situação presente dos segmentos negros em diferentes regiões e contextos do Brasil. (...) Contemporaneamente, portanto, o termo quilombo não se refere a resíduos ou resquícios arqueológicos de ocupação temporal ou de comprovação biológica. Também não se trata de grupos isolados ou de uma população estritamente homogênea. Da mesma forma, nem sempre foram constituídos a partir de movimentos insurrecionais ou rebelados, mas, sobretudo, consistem em grupos que desenvolveram práticas cotidianas de resistência na manutenção e reprodução de seus modos de vida característicos e na consolidação de um território próprio. (O'DWYER, 2002. p. 18) 
É nessa perspectiva que refletimos sobre a necessidade de ressignificar o ser quilombola e o território quilombola constantemente, pois a identidade é dinâmica, é mutável e adaptável. Assim, é necessário que órgãos governamentais, ONGs, estudiosos e pesquisadores abram possibilidades para uma nova análise desses sujeitos de suas próprias histórias, mas que esse ressignificar seja construído pelos próprios remanescentes, levando em consideração "como os próprios sujeitos se autorrepresentam e quais os critérios político-organizativo que norteiam suas mobilizações e forjam a coesão em torno de uma certa identidade". ${ }^{35}$

A ressignificação e a construção da territorialidade quilombola são imprescindíveis para uma identidade coletiva que busca mudanças e melhorias no que diz respeito aos direitos da população remanescente dos quilombos, de forma que possam garantir e legitimar as comunidades a partir de seus próprios critérios de sociabilidade - critérios de produção e reprodução coletiva baseadas na ancestralidade étnica e multiétnica que ocorre na dinâmica das relações sociais.

Precisamos compreender o território como um espaço político-social de efetivação de poder, mesmo que o território possua significados peculiares a cada área de conhecimento, como na Antropologia, Sociologia, Psicologia, Ciências Sociais, Geografia e na História. Observa-se que território, em qualquer acepção, está relacionado com poder, mas não apenas com o tradicional "poder político". Ele diz respeito tanto "ao poder no sentido mais explícito, de dominação, quanto ao poder no sentido mais implícito ou simbólico, de apropriação"36.

Haesbaert esclarece os sentidos que o território toma, ao mesmo tempo, objetivo e subjetivo, visto que:

(...) nasce com uma dupla conotação, material e simbólica, pois etimologicamente aparece tão próximo de terra-territorium quanto de térreoterritor (terror, aterrorizar), ou seja, tem a ver com dominação (jurídicopolítica) da terra e com a inspiração do terror, do medo especialmente para aqueles que, com esta dominação, ficam alijados da terra, ou no "temtorium" são impedidos de entrar. Ao mesmo tempo, por outro lado, podemos dizer que, para aqueles que têm o privilégio de plenamente usufruí-lo, o território pode inspirar a identificação (positiva) e a efetiva "apropriação". (HAESBAERT, 2007.p.27)

\footnotetext{
${ }_{35}$ ALMEIDA Alfredo Wagner Berno de. Os Quilombos e as Novas Etnias. In. Quilombos: identidade étnica e territorialidade. O’DWYER, Eliane Cantarino ( Org ).Editora FGV. Rio de Janeiro. 2002. p.68

${ }^{36}$ HAESBAERT, Rogério. Território e Multiterritorialidade: um debate. Artigo Geografia - Ano IX - No 17 -

Universidade Federal Fluminense. 2007. p.20-21
} 
O autor corrobora a necessidade de estarmos sempre refletindo e repensando as relações dos sujeitos com o território, pois o território é sempre múltiplo, "diverso e complexo"(... $)^{37}$. Essa multiplicidade e a complexidade das relações do sujeito com seu território e sua territorialidade precisam ser constantemente repensadas, reanalisadas e reorganizadas de acordo com as transformações e necessidades recorrentes de uma sociedade, seu modo de pensar, agir e reagir.

No caso das comunidades remanescentes quilombolas, a relação com o território é fundamental, uma vez que essa relação vai marcar a territorialidade e o modo de organização política, social, econômica, religiosa e cultural de um grupo, como enfatiza Haesbaert:

(...) territorialidade, além de incorporar uma dimensão mais estritamente política, diz respeito também às relações econômicas e culturais, pois está "intimamente ligada ao modo como as pessoas utilizam a terra, como elas próprias se organizam no espaço e como elas dão significado ao lugar".(( HAESBAERT, 2007.p.21)

Haesbaert complementa essa reflexão ao concluir que:

A territorialidade, no nosso ponto de vista, não é apenas "algo abstrato", num sentido que muitas vezes se reduz ao caráter de abstração analítica, epistemológica. Ela é também uma dimensão imaterial, no sentido ontológico de que, enquanto "imagem" ou símbolo de um território, existe e pode inserir-se eficazmente como uma estratégia político-cultural, mesmo que o território ao qual se refira não esteja concretamente manifestado (...) ( HAESBAERT, 2007.p.25)

Dialogamos na mesma perspectiva que Haesbaert, que a territorialidade não é algo pronto e acabado, fixo e imóvel; muito pelo contrário, são as dinâmicas subjetivas, abstratas e simbólicas que fortalecem e dão sentido à construção de um espaço político, social, econômico e cultural. É esse anacronismo que precisa ser visto e considerado, pois não podemos pensar a territorialidade a partir de arquétipos criados por políticas restritivas e excludentes que não consideram seus agentes transformadores como sujeitos fundantes para evolução do processo social dos grupos que buscam reconhecimento e reparação de direitos.

A complexidade que envolve as relações dos sujeitos com o território e sua territorialidade é o que instiga cada vez mais estudos e pesquisas nesse campo, pois são situações dinâmicas de mudanças, de articulações, de adaptações, readaptações,

37 Idem. p.21 
construções e reconstruções de significados que dão sentido à vida e à história desses agentes. É nessa perspectiva que outros olhares devem se voltar para esse fluxo de transformações, como as instituições governamentais e jurídicas, por exemplo. É fundamental que ocorram readequações na legislação e nas políticas públicas para que venham atender às necessidades dos grupos sociais, sobretudo, as populações indígenas e quilombolas que foram prejudicadas no passado, que ainda não foram atendidas o suficiente no presente e que, infelizmente, enxergam um futuro de incertezas devido à ideologia política de retirada de direitos proposta pelo atual governo brasileiro.

\section{Identidade e Etnicidade}

Ao falarmos de grupos étnicos e multiétnicos, torna-se necessário compreendermos, mesmo que rapidamente, o que significa a etnicidade e seu papel dentro da construção da identidade quilombola.

Utilizaremos aqui Philippi Poutignat que, em Teorias da Etnicidade, classifica etnicidade como "forma de organização social, baseada na atribuição categorial que classifica as pessoas em função de sua origem suposta que se acha validada na interação social pela ativação de signos culturais socialmente diferenciadores" 38 .

Essa organização social é o território e quem faz parte desse território interage com seus membros através do modo de vida, de práticas, de ideologias, e interesses em comum, criando símbolos e significados de pertencimento identitário.

Barth (2000) fala dos "sinais de pertencimento peculiar de cada indivíduo/grupo". Sinais estes que, onde estiverem, irão demonstrar características do pertencimento ao seu grupo étnico. São essas peculiaridades que irão, também, diferenciar os de um e os de outros grupos, já que a identidade gera diferença. Esses grupos étnicos, que são grupos identitários, constroem suas identidades de acordo com o contexto em que estão inseridos. Uma vez que a identidade não é fixa, ela pode se transformar, é dinâmica, construída e reconstruída. Uma pessoa pode sair do local em que vivia com aquele grupo, porém, ela não vai deixar de pertencer àquela identidade. Um indígena que sai de sua aldeia não vai deixar de ser indígena, pois carrega consigo os sinais identitários daquele grupo. Um quilombola que sai do seu território também não vai perder sua identidade quilombola pelo fato de não estar na terra, ocupando aquele espaço físico; a identidade vai muito além do

\footnotetext{
38 POUTIGNAT Philippi . Teorias da Etnicidade. Seguido por Grupos étnicos e suas fronteiras, de Fredrik Barth. Philippi Poutignat , Jocelyne Streiff- Fenart; tradução de Elcio Fernandes. São Paulo: Fundação Editora da UNSEP, 1998. p.141.
} 
físico, do concreto e do objetivo. A identidade é o sentimento, é o subjetivo, é o aprendizado e o pertencimento que cada um carrega dentro de si ao se identificar e se integrar a um grupo.

Nessa mesma perspectiva da etnicidade, Barth esclarece que grupo étnico é geralmente entendido na literatura antropológica como a designação de uma população que:

1- $\quad$ em grande medida se autoperpetua do ponto de vista biológico;

2- compartilha valores culturais fundamentais, realizados de modo patentemente unitário em determinadas formas culturais;

3- constitui um campo de comunicação e interação;

4- $\quad$ tem um conjunto de membros que se identificam e são identificados por outros, como constituindo uma categoria que pode ser distinguida de outras categorias da mesma ordem. (BARTH,2000. p.27)

O autor enumera as principais características que identificam populações autodeclaradas pertencentes a um grupo étnico, que interagem entre si, articulam e constroem campos simbólicos fundamentais para organização político-social da díade território-identidade, tendo em vista que "a comunidade étnica controla parte dos processos de socialização de seus membros e demarca um território, permanente ou transitório, ao qual atribui valor prático e simbólico"39.

São esses grupos étnicos, representantes da memória de seus antepassados, que: através da luta coletiva, constroem suas próprias territorialidades, com suas peculiaridades, conflitos, articulações e dinâmicas comuns a todo grupo social; através da luta, busca visibilidade, respeito, reconhecimento e equidade. Todos esses fatores correspondem à construção da identidade de um povo; identidade essa que é móvel, é dinâmica e é constantemente reinventada.

Não teríamos como discutir identidade sem dialogarmos com Stuart Hall, referência nos estudos relacionados à identidade. Um dos grandes pontos que o autor chama a atenção é para o fato de não pensarmos a identidade como algo definitivo, fixo e unificado, pois a identidade é uma construção social e histórica:

Essa identidade é definida historicamente e não biologicamente. Como explica Hall (2006): [...]o sujeito assume identidades diferentes em diferentes momentos, identidades que não são unificadas ao redor de um "eu" coerente. Dentro de nós há identidades contraditórias, empurrando em

\footnotetext{
${ }^{39}$ BARTH, Fredrik. O guru, o iniciador e outras variações antropológicas. Tradução: John Cunha Comerford. Rio de Janeiro: Contra Capa Livraria, 2000.p.70
} 
diferentes direções, de tal modo que nossas identificações estão sendo continuamente deslocadas [...]. A identidade plenamente unificada, completa, segura e coerente é uma fantasia. Ao invés disso, à medida que os sistemas de significação e representação cultural se multiplicam, somos confrontados por uma multiplicidade desconcertante e cambiante de identidades possíveis, com cada uma das quais poderíamos nos identificar - ao menos temporariamente. (HALL, 2006.p. 13)

Segundo Hall, é natural que haja interação social. O autor desmitifica a ideia de unidade, de preservação total, de pureza, visto que essa dinâmica híbrida e de transformação é o que molda as novas identidades. Aponta, ainda, que houve um esforço muito grande por parte das grandes nações do mundo moderno para tentar estabilizar o mundo social, mas que isso entrou em declínio "fazendo surgir novas identidades e fragmentando o indivíduo moderno, até aqui visto como um sujeito unificado" 40

Muitas vezes, o surgimento dessas novas identidades gera conflitos e não aceitação por parte daqueles que acreditam no conservadorismo, na manutenção da tradição única e homogênea, sem levar em consideração as mudanças e transformações que toda sociedade passa ao longo dos tempos e as necessidades comuns de adaptações diversas.

Compreendemos que "a unidade, a homogeneidade interna, que o termo 'identidade' assume como fundacional não é uma forma natural, mas uma forma construída de fechamento: toda identidade tem necessidade daquilo que Ihe "falta'" ${ }^{41}$

Essas novas identidades, a identidade construída social e historicamente, e a necessidade que toda identidade tem daquilo que Ihe falta, bem esclarecidas por Stuart Hall, vêm ao encontro da construção identitária dos remanescentes quilombolas, que estão em constante busca e construção de suas identidades. A comunidade Abolição é um exemplo dessa necessidade, dessa busca e dessa construção. $O$ estudo prosopográfico nos revelou que muitos remanescentes não compreendem ainda qual é o seu papel como sujeito quilombola, sequer compreendem o que é ser quilombola, mas o sentimento de pertencimento e as memórias estão presentes. Os vários encontros, o hibridismo e até mesmo o memoricídio são fatores para essa não compreensão. No entanto, aqueles que há muito tempo já se sentiam sujeitos e parte do processo histórico buscaram compreender mais afundo o seu papel e dos seus antepassados e descendentes na dinâmica de organização social daquele território. A partir dessa consciência adquirida no coletivo, a identidade começa a se moldar, com base na ancestralidade, na territorialidade, nas

\footnotetext{
${ }^{40}$ HALL, Stuart. A identidade cultural da pós-modernidade. São Paulo: DP\&A, 2006.p.07

${ }^{41}$ Idem. p. 110
} 
dinâmicas sociais e culturais de pertencimento e de adaptação às transformações ao longo do tempo. É assim que a construção identitária da comunidade quilombola Abolição está se fortalecendo. Esse fortalecimento reflete na luta e na busca por reconhecimento daquele grupo social naquele território, reconhecimento de uma ancestralidade que ali se organizou social, econômica e culturalmente. Com base nesse reconhecimento e nessa valorização, exigem o cumprimento de fato da legislação que lhes garante reconhecimento e reparações materiais e imateriais.

\section{Considerações Finais}

Foi um grande desafio encontrar referências bibliográficas que nos embasassem para compreendermos mais a situação dos remanescentes que vivem fora de seus territórios. Infelizmente, concluímos que são poucos os estudos que se dedicam a esse aspecto da história afro-brasileira. Ao mesmo tempo, também se torna desafiadora a ideia de ingressar por este caminho quase que solo.

Com isso, buscamos chamar a atenção, neste texto, para os remanescentes que estão fora de seus territórios aguardando a titulação de suas terras para retornarem. A dificuldade enfrentada está na própria legislação, que reconhece o direito apenas daqueles que estejam ocupando o território. Não levam em consideração que a sociedade está em constante transformação e uma dessas transformações refere-se ao fato de muitos remanescentes não estarem ocupando as terras de seus territórios. A ocupação física não pode significar exclusividade de direitos ou sua exclusão, uma vez que o quilombola não deixará de ser quilombola por encontrar-se distante fisicamente do seu território. Por mais que a identidade seja móvel, construída e reconstruída, a partir do momento em que a pessoa se autodeclara, tem o reconhecimento do grupo étnico, tem uma história de vida dentro de uma territorialidade construída com base naqueles ancestrais e deseja regressar ao seu território. É preciso considerar seus direitos quanto à questão identitária, direitos materiais e imateriais, inclusive, direitos relacionados à posse e titularidade da terra.

A situação desses remanescentes que estão fora do território nos possibilitou lançar um outro olhar sobre o ser quilombola e sua relação com o espaço físico. A distância do território físico não distancia da história, da memória, da continuidade simbólica e do pertencimento àquela ancestralidade.

A Comunidade Quilombola Abolição recebeu a certificação de autorreconhecimento no ano de 2005, porém, a demarcação do território, reintegração de posse e titulação ainda 
estão em fase processual no INCRA. Esses processos e demais imbróglios jurídicos dificultam e retardam a efetivação desses direitos.

Readequações precisam ser feitas para dar visibilidade, garantia e efetivação de direitos para esses grupos, os quilombos contemporâneos, pois só assim poderemos pensar em reparações concretas e justas para aqueles que ainda estão à margem do olhar do poder público e da justiça.

\section{Referências Bibliográficas}

ALMEIDA Alfredo Wagner Berno de. Os Quilombos e as Novas Etnias. In. Quilombos: identidade étnica e territorialidade. O'DWYER, Eliane Cantarino ( Org ).Editora FGV. Rio de Janeiro. 2002.

BARTH, Fredrik. O guru, o iniciador e outras variações antropológicas. Tradução: John Cunha Comerford. Rio de Janeiro: Contra Capa Livraria, 2000.

ESTRELA da Costa, Ana Carolina. Quilombo Amaros de Paracatu. Belo Horizonte/MG: FAFICH, 2015.p. 01. In. Coleção Terras de Quilombos. Incra, Ministério do Desenvolvimento Agrário (MDA) e Universidade Federal de Minas Gerais (UFMG). Belo Horizonte/MG, 2015.

HAESBAERT, Rogério. Território e Multiterritorialidade: um debate. Artigo Geografia - Ano IX - № 17 - Universidade Federal Fluminense. 2007.

HALL, Stuart. A identidade cultural da pós-modernidade. São Paulo: DP\&A, 2006.

INCRA- Relatório de Caracterização histórica, econômica, ambiental e sociocultural: território quilombola Abolição. Processo n`54240.005251/2005-08 Cuiabá, 2019.

JÚNIOR, Emmanuel de Almeida Farias. A Judicialização dos conflitos socioambientais: quilombolas e ribeirinhos em Novo Airão/Amazonas. In. Direitos quilombolas \& dever de Estado em 25 anos da Constituição Federal de 1988. Rio de Janeiro: ABA, 2016.

LITTLE, Paul E. "Territórios Sociais e Povos Tradicionais no Brasil. Por uma antropologia da territorialidade", Anuário Antropológico. Rio de Janeiro: Tempo Brasileiro, 2004.

LOURENÇO, Sonia Regina. Comunidades Quilombolas de Chapada dos Guimarães. In. Direitos quilombolas \& dever de Estado em 25 anos da Constituição Federal de 1988 / organização de Osvaldo Martins de Oliveira. - Rio de Janeiro: ABA, 2016.

O'DWYER, Eliane Cantarino (Org.) Quilombos: identidade étnica e territorialidade. Editora FGV. Rio de Janeiro. 2002.

POUTIGNAT Philippi . Teorias da Etnicidade. Seguido por Grupos étnicos e suas fronteiras, de Fredrik Barth. Philippi Poutignat, Jocelyne Streiff- Fenart; tradução de Elcio Fernandes. São Paulo: Fundação Editora da UNSEP, 1998. 
STONE, Laurence. Prosopography. In: Daedalus: journal of American Academy of Arts and Sciences, vol. 100, № 1, 1971.

www.mpf.mp.br. MPF recomenda que Sema suspenda licença de pedreira em Santo Antônio de Leverger (MT). Publicado em 17 de março de 2020. 


\section{Capítulo 03}

VIDAS NOTURNAS E DIURNAS DAS MULHERES NEGRAS ESCRAVAS, FORRAS E LIBERTAS EM SUAS ATIVIDADES COTIDIANAS: TEMPO, TRABALHO, DIVERTIMENTO E BOEMIA NA FREGUESIA DE PEDRO II (MATO GROSSO, SÉCULO XIX)

\section{JHUCYRLLENE C. DOS SANTOS RODRIGUES ${ }^{42}$}

Este estudo buscou compreender como era a vida das mulheres negras, forras e libertas na freguesia de Pedro II no século XIX. Para tanto, intentamos refletir sobre a organização dos seus espaços, os tipos de trabalhos disponíveis no local (tanto para mulheres quanto para homens) - especialmente, aqueles ligados às tavernas, bares, padarias, botequins, ao lazer e divertimentos de "brinquedo-batuque" e, ainda, nas casas de livre acesso, onde tanto homens livres quanto escravos forros e libertos, pobres, mestiços e negros participavam dessa movimentação revestida de prazer. Buscou-se, também, propiciar foco à figura feminina: as trabalhadoras dos espaços urbanos da Cidade de Cuiabá, com destaque para aquelas que tinham desempenho no segundo Distrito de Cuiabá, o de Pedro II (hoje, bairro do Porto), durante o século XIX, mais especificadamente entre os anos de 1860 e 1888.

A pesquisa foi fundamentada em várias tipologias documentais: jornais e ProcessosCrime do Cartório do 6º Ofício e do Tribunal da Relação, especialmente das séries penais relativas à embriaguez, à turbulência da ordem pública, a homicídios e suas tentativas, à lesão corporal leve e pesada, dentre outras. Esse conjunto documental foi encontrado no Arquivo Público de Mato Grosso (APMT) e no Núcleo de Documentação e Informação Histórica Regional (NDIHR/UFMT).

O objetivo do estudo, que dialoga com os postulados de Edward P. Thompson, Michel de Certau, Gilberto Freire, Mary Del Priore, Sidney Chalhoub, Martha Abreu, Margareth Rago, Delso Renault e Luiz Carlos Soares, foi revelar como eram presenciadas as práticas sociais expressas nas festas de brinquedo-batuque, ligadas às práticas sexuais, vividas pelas camadas sociais inferiores da população cuiabana, na primeira metade do século XIX.

Destarte, em um primeiro momento, analisaremos $A$ vida cotidiana em Cuiabá entre o tempo, trabalho e divertimentos, conhecendo, assim, as rotinas diárias dos moradores locais e, principalmente, as famílias dos negros e negras escravizados, forros, libertos, livres e brancos pobres. Além disso, analisaremos como eles administravam o tempo de

\footnotetext{
42 CAMPOS, Jhucyrllene Santos Rodrigues é licenciada em Pedagogia e História, e possui mestrado pelo Programa de Pós-Graduação em História da Universidade Federal de Mato Grosso. E-mail:

prof.jhucy@gmail.com.
} 
trabalho pesado durante o período de trabalho com o tempo de divertimento entre os brinquedos, as casas de livre acessos e das festas populares de batuques, cururu e siri.

Depois, refletiremos sobre Os espaços perigosos e boemia na Freguesia de Pedro II. Através dos processos crimes e denúncias feitas pelos jornais locais, serão descritos movimentos ligados aos divertimentos das festas dos batuques nas casas de brinquedos e os conflitos e brigas que ocorriam nesses lugares por causa do alto consumo de bebidas alcoólicas e disputas pela companhia feminina no local.

\section{A vida cotidiana em Cuiabá entre o tempo, trabalho e divertimentos.}

A vida cotidiana da cidade de Cuiabá era estruturada de forma distinta quando comparados os mais variados tipos de indivíduos que constituíam os estratos sociais daquele momento, ${ }^{43}$ permitindo-nos estabelecer algumas semelhanças e diferenças estruturais entre homens, mulheres livres, pobres, índios e escravos, que dedicavam muitas horas diárias fazendo a cidade funcionar. Para as elites, a lógica era a de que seus divertimentos fossem organizados de forma que contribuíssem com as obrigações do labor cotidiano. As camadas populares lutavam por buscar autonomia no quesito lazer e divertimento (GONÇALVES FILHO, (2009).

Reis (2002), ao tratar das classes chamadas escravas, nas quais ele incluía homens e mulheres livres pobres, considerava que, além dessas pessoas terem suas vidas particulares controladas, elas também sofriam o controle em seu tempo de lazer. Ademais, tais sujeitos da classe pobre e escrava sempre buscavam uma válvula de escape para contornar essa repressão e, ao mesmo tempo, mostrar a sua luta pelo direito de poder manifestar o seu prazer pela vida, com base no divertimento e lazer; isso se efetivava por meio das festas.

Seguindo os relatos dessa primeira metade do século XIX, o significado da palavra "tempo" era compreendido como uma divisão de espacialidade entre o trabalho corriqueiro e os momentos poucos, caso sobrassem, em que não haveria trabalho a ser feito. Assim, seria possível descansar e usar esse escasso momento para o lazer e o divertimento. Moura (1998) afirmava que o "[...] trabalho e o lazer misturavam-se imprimindo uma especificidade ao viver, conviver e lidar com toda a sociedade". Contudo, para as elites, a

\footnotetext{
${ }^{43} \mathrm{O}$ entendimento na perspectiva do que se refere à "classe social" está subentendido, em Thompson (1987, p. 9), quando afirma que "[...] um fenômeno histórico, que unifica uma série de acontecimentos díspares e aparentemente desconectados, tanto na matéria-prima da experiência como na consciência. Ressalto que é um fenômeno histórico. Dessa forma, não vejo os segmentos enquanto 'estrutura', nem mesmo como uma 'categoria', mas como algo que ocorre efetivamente e cuja ocorrência pode ser demonstrada nas relações humanas".
} 
mistura entre divertimento, lazer e liberdade possuía um significado de baderna, turbulência e perturbação, pois quase sempre redundavam em ações proibitivas e prisões.

Todavia, na Cuiabá do século XIX, muitos integrantes das elites possuíam o comércio e a lavoura como atividade laboral, funções que também eram desempenhadas por escravos, dependendo de sua classificação e categoria de trabalho. Os escravos domésticos, como o próprio nome já afirma, trabalhavam dentro dos lares e dos comércios locais; já os escravos de ganho, trabalhavam na cidade. Porém, no final do trabalho, eles teriam de voltar para a casa de seus donos e, ainda, dar um percentual a mais do seu salário para compensar a sua ausência de trabalho ao seu dono. Em relação aos escravos de jornais, afirma-se que trabalhavam de forma semelhante ao escravo de ganho, no entanto, a maioria deles possuía um nível de leitura e escrita igual ao "homem branco"; aqueles negros livres e pobres, considerados camaradas, eram agregados a pequenos lavradores, trabalhadores de ofício, soldados, condutores de tropas, mineiros pobres, domésticos, vendedoras de tabuleiros, quitandeiras, artesãos, lavadeiras etc.

Segundo a descrição de Gomes (2011), essa divisão de trabalho, que ocorreu durante o século XIX, com a chegada dos imigrantes italianos, efetivava-se como uma espécie de divisão de trabalho; era nomeada como de empregados técnicos e/ou especializados, ou seja, eram ambientes de trabalho, onde cada trabalhador iria desenvolver seu ofício, tanto na cidade quanto no campo.

De um lado, existiam trabalhadores pobres, formados por brancos, índios e negros ex-escravos; do outro, haviam os trabalhadores nacionais e/ou estrangeiros, os quais desenvolviam atividades especializadas. Cada um deles recebia os seus salários de acordo com seu ofício e desenvolvimento intelectual da leitura, da escrita e da comunicação.

Nessa última camada social, existiam pessoas brancas, indígenas e negros livres, bem como seus respectivos descendentes, a exemplo dos mestiços, que eram considerados cabras, mulatos, crioulos, caburés, pardos etc.

Dessa forma, existiam as divisões sociais de trabalho no segmento das classes humildes, em que cada indivíduo poderia ser um pequeno patrão, mesmo se estivesse com poucas posses ou, até mesmo, sem nada. Todavia, trabalhava por conta própria e com autonomia entre ruas, avenidas e becos da cidade, como mascates, caixeiros viajantes e vendedores ambulantes.

Assim, as pessoas que possuíam pequenos empreendimentos pelas ruas da cidade, efetivamente, poderiam precisar da ajuda de alguém; diante disso, havia uma demanda por mão de obra de trabalhador autônomo, de maneira que eram os escravos de ganho, forros e os libertos que, geralmente, tinham habilidades na escrita e nos cálculos matemáticos os 
que trabalhavam nessas ocupações. Por outro lado, existiam pessoas que não conseguiam emprego formal ou informal, de modo que sua única alternativa era sair pedindo ajuda ou dinheiro nas ruas e becos da cidade.

As relações de trabalho entre patrões e empregados poderiam ser compreendidas a partir de acordos firmados entre as duas partes, com a estipulação das atividades a serem desenvolvidas a partir dos serviços prestados para que se pudesse chegar ao valor a ser pago pelo serviço prestado. Quanto ao tempo de serviço, isso poderia variar de um dia a duas semanas ou meses, como no caso de colheita ou até mesmo de serviços em estabelecimentos comerciais.

Para aqueles indivíduos que almejassem trabalhar em casa de família, mas que não eram escravos, haviam atividades, como de pedreiro, de ferreiro, de marceneiro e de jardineiro, com pagamento pelo dia trabalhado. Segundo Volpato (1996), nos ambientes rurais, os indivíduos que não fossem escravos também prestavam os seus serviços em lavouras, fazendas de criação de animais, engenhos e, também, nas minas, com a extração de minérios. Desse modo, a diferença desses indivíduos pobres, livres e não escravos era percebida a partir dos seus pagamentos recebidos pelos seus serviços; às vezes, essas diferenças efetivavam-se, também, da seguinte forma: muitos desses trabalhadores livres tinham as famílias na cidade e, somente na temporada de serviço, é que se ausentavam de suas casas. Ademais, possuíam também liberdade de circular livremente pela cidade sem nenhuma restrição e, até mesmo, de participar das festas dos brinquedos, as quais fossem legalizadas.

Aqueles que eram escravos e que precisassem sair para as ruas ou fazer compras para seus senhores teriam de estar com uma carta de autorização informando os motivos de sua presença naquele local; porém, alguns donos de escravos apresentavam certa flexibilidade e deixavam um escravo de confiança sair para se divertir em bares, tavernas ou brinquedos. Caso o escravo perdesse essa autorização ou não a levasse consigo e fosse preso, ele seria levado para a delegacia, seria lavrada a ocorrência, seu dono seria comunicado e teria que pagar uma fiança. Consequentemente, esse escravo sofreria mais tarde algum tipo de punição por essa contravenção de conduta na cidade.

Haviam, ainda, no espaço, os ex-escravos considerados forros, que trabalhavam por conta própria como se fossem pequenos comerciantes da cidade. Fato observado por Edvaldo de Assis, que menciona dois escravos forros, os quais tinham seu próprio comércio: porcos e fornecia toucinho aos Armazéns do Príncipe da Beira do Rio. 
O Segundo Caso: Preto Forro chamado Domingos Martins, Bernardo Veiga e Cipriano José, que tiveram seus bens penhorados, por serem devedores de dívidas. O primeiro devedor da Capital e os últimos dízimos. Na documentação não foram mencionados os bens penhorados, mas eles possuíam casas, gados vacuns e pequenas terras (ASSIS, 1986, p.6).

No mesmo periódico citado acima, o historiador faz menção a outros tipos de negros forros que compravam escravos para suas propriedades e, até mesmo, os disponibilizavam para aluguel, ou seja, faziam transações comerciais iguais aos "homens brancos", como existia na capital.

[...] No conjunto de proprietários de negros forros encontra-se duas referências de comércios: A primeira no requerimento onde diz: José, escravo de Francisco da Silva, que sua mulher Maria Correa preta forra, comprou a escrava Joaquina, em Cuiabá por uma libra e meia de ouro, pagando no início da compra a quantia de meia libra, ficando devendo uma libra ao antigo dono da escrava (ASSIS, 1986, $p$ 8).

A segunda referência foi registrada pelo viajante Hercules Florence, quando observou as relações sociais dos negros forros a partir de suas rotinas diárias, tanto sociais quanto de trabalho. Dessa forma, os forros poderiam ser vistos trabalhando em engenhos; em criadouros de porcos, de galinhas, de vacas e bois; nos transportes de mercadoria para o Porto Geral; como pedreiro, carpinteiro, seleiro, entre outros. As mulheres forras poderiam ser encontradas vendendo iguarias pela cidade, respeitando as determinações exigidas pelo código de postura, como a hora em que elas poderiam circular nas ruas. Então, os negros forros, que trabalhavam nesses ofícios na cidade e na zona rural, passaram a ser trabalhadores assalariados nesse contexto histórico.

Assim, vale ressaltar que os indivíduos considerados escravos eram privados de sua liberdade social, mas, em contrapartida, os forros possuíam um certo prestígio, assim como os indivíduos pobres e livres. Ao investigar essa questão da liberdade social, constata-se que os escravos lutavam de forma persistente, buscando ter esse pequeno momento de liberdade e distração, mesmo que fosse às escondidas ou, até mesmo, autorizado pelos seus senhores - nesse caso, isso poderia acontecer em vários pontos, tais como nas senzalas, nas rodas de batuque, nas rodas de folguedo ou nos quintais das casas dos seus senhores.

É nesse contexto que verificamos um entrelaçamento entre a convivência do privado e do público. A pesquisadora Siqueira (1999) evidenciou essas tais vivências entre indivíduos livres pobres e os negros escravos ou libertos nos espaços sociais da cidade de Cuiabá, afirmando que as pessoas das classes sociais mais inferiores costumavam se divertir de forma livre e espontânea entre rodadas de pinga e aguardente nos bares, 
tavernas e botequins, ou, até mesmo, nos espaços privados de quintais residenciais ou de fazendas. Dessa maneira, praticavam as festas do brinquedo em ritmo de batuque, cururu e siriri.

Reforçando essa ideia de resistência e de luta em busca da liberdade dentro dos espaços urbanos, nos quais fosse possível praticar a própria fé religiosa nas matrizes africanas, como também na forma de divertimento em reuniões familiares ou de amigos, em rodas de conversa nos batuques e nos brinquedos, temos, também, outra forma festiva que os olhares da sociedade cuiabana condenavam e rotulavam como pecaminoso, cheio de luxúria, barulhento, turbulento; para eles, ali, reuniam-se somente pessoas de má fé, como vadios, prostitutas e ladrões.

Esse pensamento que desqualificava os espaços de divertimentos das classes pobres brancas, mestiças, escravas, libertas, forras e livres, que observamos nos discursos apresentados pelas autoridades policiais e por alguns moradores, sem ao menos conhecerem o lugar direito, só acontecia a partir do momento em que estavam reunidas essas pessoas. Então, os policiais e os guardas de quarteirão eram chamados para averiguar se, naquele local, estavam ocorrendo os divertimentos ilícitos.

No viés desse reforço pela proteção e pela segurança popular, surge o Código de Postura, ou seja, uma medida preventiva que propiciaria segurança e paz para a comunidade local. Vale ressaltar que essa medida preventiva do Código de Postura não era restrita ao Mato Grosso, mas implantada a nível nacional pela Corte Portuguesa, por meio do Governo Imperial. O objetivo do Código de Postura era de que a sociedade criasse um modo de vida saudável e harmônico nesse momento. A pesquisadora Volpato (1993) descreve como essas medidas sociais foram impostas na sociedade cuiabana, durante o Período Imperial:

[...] pelo alto índice de atritos que ocorriam nessas reuniões das festas, funções, divertimento, batuques eram vistos pelas autoridades como momentos privilegiados de brigas e por isso deveriam ser no máximo evitados (VOLPATO, 1993, p 205).

Nesse contexto de proibições ligadas ao divertimento e ao lazer, incluíam-se, também, alguns jogos de cartas, considerados de azar. Tal proibição foi incluída a partir de 1881, nas alterações ocorridas no Código de Postura; esses itens foram descritos dentro da norma como "Dos jogos e reuniões ilícitas, vozerias e ofensas à moralidade pública" de no 17. A partir daquele momento, todas as pessoas que fossem flagradaspraticando jogatina ou reuniões ilícitas poderiam sofrer sanções por parte da polícia ou deveriam pagar multa à Câmara Municipal. Vejamos, então, os itens que compunham essas proibições preventivas sociais: 
Art. 65 - Fica expressamente proibido:

$\S 1^{\circ}-$ Fazer bulha ou algazarra e dar altos gritos à noite.

$\S 2^{\circ}-$ Fazer sambas, cururus e outros brinquedos que produzem estrondo dentro desta cidade.

$\S 3^{\circ}$ - Conceder ou sustentar controvérsias em altas vozes pelas ruas quer de dia, quer de noite.

$\S 4$ - Proferir palavras obscenas ou licenciosas que ofendam o pudor das famílias ou moral pública.

$\S 5^{\circ}$ - Escrever nas paredes dos edifícios e dos muros palavras, frases ou

dístico simples ou imoral, bem como desenhar figuras obscenas.

$\S 6^{\circ}$ - Andar pelas ruas nu ou indecentemente vestido, com roupas dilaceradas ou sem que traje pelo menos calça e camisa.

$\S$ 7ㅇ- Banhar no Porto Geral desta Cidade na extensão compreendida da rampa da barca pêndula até a boca do vale inclusive, assim como em todos os portos dos povoados do Município o que sejam embarque e desembarque.

$\S 8^{\circ}$ - Estar na própria casa ou na alheia de modo indecente ou imoral, de sorte que seja visto ou notado pelos transeuntes ou vizinhos.

Art. $66^{\circ}$ - Fica igualmente proibido:

$\S 1^{\text {O- }}$ Todos os jogos de parada ou apostas por meios de cartas, dados, roletas ou quaisquer outros.

$\S$ 2-- A reunião de escravos, filhos, famílias, fâmulos ou criados nas lojas, travessas ou praças. Os infratores serão multados em dez mil reis ou sofrerão

cinco dias de prisão.

Art. $67^{\circ}$ - Serão também considerados infratores do

$\S 2^{\circ}$ do artigo 65- E do presente artigo os donos das casas em que fizerem os divertimentos, jogos e reuniões sem autorização prévia da Câmara. ${ }^{44}$

Esses hábitos, considerados antissociais, eram percebidos como degradantes pelas famílias conservadoras, pois, quando essas ações eram praticadas, distanciavam as pessoas por causa das bebidas e dos jogos. Isso porque, na maioria das vezes, deixavam o indivíduo endividado, de maneira que perdia tudo o que tinha e causavam intrigas, por conta das traições conjugais que redundavam na descoberta de amantes, concubinas e filhos ilegítimos.

Assim, acentuando esses fatores de riscos, o jornal O Povir apresentou uma matéria, publicada no ano de 1877, intitulada de As consequências do jogo. Tal texto reforçava para a população que esse tipo de divertimento só ocasionava infelicidade no meio social e familiar:

O jogo é a concentração rápida de todos os vícios em um só; a transformação rápida e sucessiva do passatempo em vício, do vício em crime, em atentado; o culto a uma divindade ímpia, que perde dinheiro, depois os bens, depois a honra, depois a família, depois a vida, finalmente a alma; a fortuna que conduz a sua vítima crédula e confiada por entre caminhos bordados de flores, para depois a despertar num precipício ao som de uma estrondosa gargalhada. ${ }^{45}$

De fato, essa era a realidade de muitos cidadãos cuiabanos, os quais eram influenciados por esse tipo de divertimento relatado no jornal O Povir. Entretanto, os jogos

\footnotetext{
44 Decreto no 577 . Postura Municipais de Cuiabá. Cuiabá 30 de novembro de 1880. IMPL- Livro de Registro dos Decretos e Resoluções.

45 O PORVIR. Vício do Jogo- no 25. Cuiabá 15 de dezembro de 1877/15/dez. APMT- Coleção de Jornais.
} 
não eram só praticados no interior das camadas pobres livres ou no segmento escravo, uma vez que algumas pessoas das elites também frequentavam casas de jogos.

Todavia, esses lugares apresentavam características mais sofisticadas, pois seus ambientes eram presenciados pelos homens de posse, que ficavam até altas horas da madrugada, jogando, acompanhados de rodadas de whisky, de champanhe e de vinhos importados; em uma conversa ou outra, com ganhos ou perdas, alguns podiam até perder tudo que tinham nas apostas, ficando endividados.

Para solucionar esse impasse, muitos chefes de família, arruinados pelas dívidas de jogos, tendiam a arranjar casamentos para suas filhas na puberdade, na adolescência ou, até mesmo, na mocidade, com homens mais velhos da elite, como forma de saldar a dívida patriarcal de sua família.

Outro ponto relevante de se destacar nessa cultura do divertimento da elite cuiabana pode ser observado por meio da conduta social do Presidente de Província, o Barão de Batovi. Ele gostava, particularmente, de se reunir no Palácio, juntamente de outras pessoas da elite cuiabana, para tratar de "negócios administrativos e financeiros" ligados ao assunto da cidade e aos benefícios que se poderia obter com seus patrimônios particulares. Isso evidencia que as reuniões consideradas políticas eram, na verdade, rodadas de charutos com jogos de cartas.

Esse tal cenário de reuniões administrativas e políticas foi descrito pelo viajante Steinen (1877), ao observar essa rotina social dentro do palácio:

[...] que muito apreciava, em companhia de dois e três senhores, no seu amplo e confortável gabinete de trabalho. Costumava oferecer-nos esplêndidos charutos paraguaios. Assistíamos ao jogo e durante os intervalos, tínhamos a oportunidade de melhorar os nossos, ainda bem falho, conhecimentos de português. [...] Às 19 horas era servido o chá de origem paraguaia ou chinesa, acompanhado de excelentes biscoitos. Pouco a pouco os jogadores acabavam o entretenimento, fazendo as contas dos grãos de milho, conversando ainda um pouco, e retirandose pontualmente.

O viajante alemão percebeu que, na relação social da elite com a política, buscavase interagir de forma pacífica, se possível, quando suas famílias, mulheres e filhos pudessem participar, mas, quando isso se tornava impossível, a figura da mulher amante e prostituta entrava em cena, como acompanhante nos bailes luxuosos, com pianos, orquestra, sarau literário com musicais promovidos pela elite no Palácio.

Sendo assim, Steinen não ficou somente nesse ambiente de festa da elite, mas desejou conhecer também as festas populares, que eram efetivadas com brinquedo/batuques, usuais entre a camada pobre cuiabana. Diante disso, registrou suas impressões, visto que ficou chocado e perturbado ao ver as cenas em que as mulheres 
dançavam com os homens, nos ritmos de siriris, cururus e sambas; ao mesmo tempo, percebeu que consumiam bebidas alcoólicas nesses espaços, sem se importarem com os falatórios e com os olhares de julgadores.

Outro aspecto interessante era o tipo de vestimenta que o povo cuiabano usava em seu cotidiano, em casa, no trabalho e nas festas. A pesquisadora Inoui (2004) apresentou, em sua dissertação de mestrado, intitulada O vestuário e suas representações na Vila Real do Bom Jesus do Cuiabá 1727-1801, como o povo cuiabano se vestia e qual a importância dos tecidos e das roupas, acentuando que eram itens considerados como objeto de extremo valor; a tal ponto que, na maioria das vezes, foram até elencados nos testamentos, percebidos como raros e valiosos.

Essas particularidades da vida cotidiana privada da elite cuiabana, presentes nos indivíduos pobres e escravos, aos poucos, foram formando o ser e estar do povo cuiabano, em suas características físicas, emocionais e culturais, as quais presenciamos até hoje, seja pelo despojado falar cuiabano, seja, até mesmo, pelos casarões históricos espalhados pela cidade.

\section{Os espaços perigosos e boemia na Freguesia de Pedro II.}

E na rua, o que se vê? O senhor do Mundo, o reclamo. Em cada praça onde demoramos nossos passos, nas janelas altas dos telhados, em mudos dos jogos e luz, os cinematógrafos e as lanternas mágicas que gritam. São os pequenos comércios sem influência de importação de indireta e direta dos caixeiros elegantes de lenços, no punho: as vendas são criação nacional, nos botequins baratos, nos bares, restaurantes, açougues, nos bazares e hospedarias para atender uma clientela barata, que vive dos prazeres da noite.

(João do Rio, 1995. p. 73-74)

O exposto feito por Rio (1995), ao narrar a vida cotidiana dos moradores da cidade do Rio de Janeiro, nos finais do século XIX, remete a uma comparação com o cotidiano da cidade de Cuiabá naquele período e, principalmente, lá na "Segunda Freguesia de Pedro II", onde existia a maior concentração comercial devido à proximidade do Porto de Navegação.

A cidade de Cuiabá estava em processo de expansão, tanto comercial quanto populacional, e o segundo Distrito era uma área em que essa movimentação acontecia diuturnamente. Ou seja, existia, nesse local, o comércio que funcionava nas madrugadas, para atender às chalanas e aos barcos que chegavam nesses horários, trazendo clientes 
e marinheiros a bordo, cansados, famintos, sedentos por bebida alcóolica e, principalmente, sentindo saudades do aconchego e da intimidade femininas.

Dessa forma, essa região acabava sendo considerada local onde se faziam "práticas ilícitas de lazer, divertimento e de descanso, envolvendo jogos, namoros, espaços festivos para festas populares ao som de músicas regionais como batuques, cururu, boi da serra, siriri e do samba". Tais práticas também eram conhecidas como "brinquedos ou casa de livre acesso", sendo a nomenclatura anterior somente para os estabelecimentos onde existia consumo de bebidas e músicas de batuque, com mulheres.

Esse território, parafraseando Ferraz de Macebo (1872, p.4), poderia ser considerado "ilícito e pecaminoso",46 o que pode ser identificado nas atas dos processoscrime do Cartório 6º Ofício e do Tribunal da Relação de Cuiabá-MT, em que os crimes contra a ordem pública eram constantemente lavrados.

Através desses sumários de desordem na cidade, é possível perceber que o comportamento da camada excluída estava restrito às suas experiências e vivências, que tornavam a cidade viva e repleta de conflito; espaço em que os discursos das autoridades locais se opunham e entravam em contradição com a realidade vivida pela população.

Entre os anos de 1860 e 1888, os crimes analisados são relacionados à quebra da ordem: embriaguez, brigas, homicídios, tentativas de homicídio envolvendo mulheres; alguns deles com envolvimento de soldados militares e oficiais ou, até mesmo, dos guardas

\footnotetext{
46 Tese apresentada à Faculdade de Medicina. Ferraz, em seu trabalho sobre o fenômeno do crescimento da prostituição na cidade do Rio de Janeiro, a partir dos relatórios descritos do Dr. Lassance Cunha, que viveu nessa época e que trabalhou no Governo do Rio de Janeiro, para tentar identificar as Prostitutas que estavam contaminadas por doenças sexuais e que precisavam de tratamento rígido, aponta que, em alguns casos, elas eram levadas ao isolamento em hospitais, mas, em outros casos, como da prevenção dessas mulheres públicas que praticavam a prostituição, eram identificadas, registradas ou notificadas a comparecer nos hospitais, para os exames de rotinas. De acordo com os relatos nesse trabalho do Ferraz, quando o Dr. Lassance, não recebia o retorno dessas mulheres no tratamento, o médico ia aos possíveis lugares onde elas poderiam estar morando, juntamente com as forças policiais, caso houvesse resistência. Nesses relatos, o médico Dr. Lassance, identifica as moradias dessas mulheres públicas e prostitutas, como lugares ilícitos e pecaminoso, que muitas vezes exalava maus-cheiros, por causa que a maioria delas vivia em pequenos quartos sem conforto e ventilação, na maioria das vezes, só tinham uma porta e uma pequena janela, o banheiro ficava no mesmo espaço do quarto e os potes que continham os resíduos pessoais, como fezes e xixi, ficavam ali. De acordo com as normas da cidade do Rio de Janeiro, esses resíduos só poderiam sair das casas à noite, para serem jogados fora, mas em outros casos muitas residências adotava um sistema de tambor, que ficavam no quintal da casa e os criados ou até mesmo os escravos, quando iam limpar as casas, poderiam jogar esses resíduos pessoais lá, e, quando chegasse à noite, esses tambores eram retirados das casas e logo em seguida eram descartados nos rios ou matos da região. Outra pesquisadora que também faz alusão a esse tipo de higiene nas casas mais aqui na cidade de Cuiabá seria à Historiadora Cavalcanti, Else Dias de Araújo, que escreveu o livro "Imagens de uma Epidemia", onde ela retrata a cidade de Cuiabá durante o século XIX e como as pessoas não se preocupavam com a higiene dos locais onde moravam ou tinham os comércios. Outro fator importante que a autora descreve é como o Código de postura ajudou a controlar o surto de Sífilis e outras doenças contagiosas que quase dizimaram a população cuiabana. A Questão da Pesquisa da Elsa não seria somente na questão da doença da cidade, mas também a falta de higiene que as pessoas tinham e fazia com que as doenças crescessem em torno da população. Dessa forma, faz jus que, se as pessoas não tinham o hábito da limpeza de suas casas e do comércio, que diriam então com a higiene corporal, que também seria de forma precária.
} 
de quarteirão. Assim, os relatos descritos nos processos-crime eram, majoritariamente, devido aos envolvimentos amorosos, com traição e ciúmes, ocorridos nos espaços festivos dos brinquedos ou nas casas de livre acesso, bares e tavernas.

No ano de 1893, foi encontrado um registro policial envolvendo um soldado do $8^{\circ}$ Batalhão da Infantaria, na casa de Cândida Francisca da Cunha, que se dizia solteira, 33 anos de idade, profissão doméstica, moradora na Freguesia de Pedro II, no local próximo à "lagoa". E esse registro policial era de categoria de homicídio:

No dia 20 do corrente ano, às oito horas da noite mais ou menos, no local denominado lagoa - no porto desta capital, na freguesia de Pedro II, estava Jacinto José da Silva praça do corpo da Polícia Militar na casa da dona Cândida Francisca, quando chegou Victor Ferira totalmente alterado com seu amigo José Francisco de Campos.

Chamando a Cândida no portão, quando a mesma saiu junto com Jacinto para fora da casa e viu Victor e José, tiveram uma discussão forte aponto do soldado Jacinto sofre uma facada no peito levando a morte (APMT- Cartório do 6 Ofício, Maço 03, 1893).

Ao analisar o processo, pode-se perceber que Cândida tinha dois relacionamentos ao mesmo tempo, visto que amante do soldado Jacinto, casado e com filhos, e do Victor, que se dizia "marido" de Cândida. Ao saber que ela estaria com outro soldado em sua casa, foi até lá para tirar satisfação, pois Victor não estava em casa nesse dia, devido a uma briga que teve com Cândida um dia antes.

A história desse crime possui várias facetas que levam à incerteza dos fatos, porque ela não foi chamada para depor e tampouco acusada pelo envolvimento no crime, constando, no final, que o soldado se envolveu em uma briga de rua nesse dia. No entanto, o amigo de Victor, que foi acusado de ter assassinado o soldado Jacinto junto com seu amigo José Francisco, confirmou a mesma versão da história, conforme depoimento de Victor.

O réu, Victor, ficou preso até que o processo fosse concluído; por falta de provas concretas sobre os motivos da sua briga com o soldado Jacinto, ele foi solto. O caso deixou algumas questões em aberto: "será que o batalhão estava tentando ocultar o caso, por se tratar de membros de sua corporação? Ou a esposa da vítima não quis levar o caso à frente por se tratar do envolvimento do esposo com uma mulher pública"?

Em se tratando da casa da dona Cândida, ficava na região da lagoa, localidade próxima do $8^{\circ}$ Batalhão da Infantaria, pela descrição nos autos, a sua residência passava pela Travessa do Soído, à Rua Conde d'Eu com a Travessa da Marinha, chegando até a Rua do Porto Geral. Segundo relatos, dona Cândida era muito famosa nessa região, pois ela era vista como uma mulher pública, que trabalhava como doméstica, durante o dia, e, 
à noite, recebia homens em sua residência, inclusive, soldados da $8^{\circ}$ Infantaria, com intuito de fazer o brinquedo.

Além dos registros policiais e depoimentos, podemos encontrar vestígios desses espaços considerados perigosos nos quais apareciam mulheres públicas em suas atividades corriqueiras do dia-a-dia nas ruas da Freguesia de D. Pedro II.

Dessa forma, o jornal "O Povo" registrou a denúncia dos moradores que se sentiam incomodados com as atitudes dessas mulheres públicas. Já antes, o jornal veiculou as matérias relativas aos crimes que ocorriam em Cuiabá e qual era a sua natureza, especificando quem eram as pessoas e quais os crimes cometidos. Vejamos:

\begin{abstract}
Ocorrências Policiais de 18 a 30 do passado mês findo. Prisões - Do escravo de D. Izabel d'Arruda Maciel, por ser encontrado às 11 horas da noite com uma faca de ponta andando nas ruas. O alienado- Graciano de Luz que estava embriagado promovia desordens na cidade. Envolvimento de Assassinato: Esmeria Maria considerada turbulenta juntamente com Silvano de Oliveira estavam embriagados e produzindo desordem nas ruas. Foram presos para averiguação do assassinato do soldado do $2^{\circ}$ Batalhão de Artilharia a pé o Morto Soldado Barnabé às pessoas suposta ao envolvimento são Manoel José Pereira, Archangela Maria, Victoriana Maria da Conceição, Suzana Maria do Rozário, Simplicia Maria, Victoriana Maria de Jesus, Ignácia Bueno de Siqueira e Maria da Conceição (NDHIR, jornal O Povo, 1868)
\end{abstract}

Ao observar essa matéria jornalística destacando o envolvimento no assassinato do soldado Barnabé, é notória a quantidade de mulheres envolvidas, mas o jornal não deixou claro os motivos do crime. Desse modo, a pesquisa se voltou para documentos arquivísticos do Cartório do 60 Ofício, série penal de assassinato, e encontramos o mesmo caso do jornal citado acima.

Nos autos do Processo, consta que o soldado Barnabé esteve em uma festa do Batuque, chamado brinquedo, em companhia destas pessoas: Esmeria Maria, Simplícia Maria, Maria da Conceição, Ignácia Bueno Siqueira, Victoriana Maria, Magdalena Leite. Todas elas eram mulheres que trabalhavam como quitandeiras no comércio da região do Porto Geral.

Nesse sentido, podemos deduzir que elas poderiam ser mulheres trabalhadeiras, mas que curtiam a prática do brinquedo como forma de divertimento; porém, não podemos afirmar com certeza se elas realmente praticavam a prostituição, pois, nos autos do processo em que elas serviram de testemunha, não fica clara essa atividade, apontando somente indícios de que elas gostavam de estar no ambiente festivo do brinquedo, em companhia de homens.

Outra questão a ser revelada seria a realização do cururu e o siriri como prática de um divertimento ligado ao batuque e ao brinquedo. $O$ silêncio sobre esse tipo de 
divertimento foi a arma empregada pelas autoridades para torná-lo invisível, pois ninguém, além das autoridades responsáveis, deveria saber do ocorrido.

Nesse campo da desordem social, considerado perigoso e que envolvia vários tipos de crimes, revelam-se os hábitos e os costumes da população em diferentes contextos de seu cotidiano, quando, muitas vezes, pessoas eram condenadas pelas autoridades policiais, que passavam a persegui-las. No entanto, nem todas as práticas de festa do batuque do cururu e siriri eram festas ligadas ao brinquedo da "prostituição", podendo ser festa com intenção de divertimento familiar.

Moutinho, ao observar uma festa do Batuque, revela-nos as suas impressões de como a dança era representada pelas pessoas que estavam naquele espaço festivo do divertimento:

[...] há também uma outra dança popular conhecida sob o nome de "batuque", que difere muito da que acabamos de descrever e que tem tanto de alegre quanto a primeira tem insipida. No batuque velho remoça e o rapaz execede-se a si mesmo no delírio do prazer. A música só por si provoca o desejo da folgaça, tanto a sua toada é agradável e excitante. Esta dança produz mais que sensações aprazíveis mais que delírio, mais que frenesi (Moutinho. 1869. p.20)

Observando as narrativas deixadas pelo mesmo autor, nota-se que ele ficou enfeitiçado pela festa do Batuque, ao escutar a música e ver sua encenação. Isso nos leva a refletir que as festas populares da camada mais pobre de Cuiabá seriam divertimento ligado ao prazer e que as pessoas exerciam em seu cotidiano. Contudo, muitas das vezes, esse divertimento não era bem-visto, como já mencionado anteriormente, pois as festas dos batuques seriam uma mistura de cultura africana não aceita pela sociedade católica.

Essa mistura de ritmo de dança festiva já era presenciada no passado, pois, no ano de 1786, na décima primeira carta Chilena de Tomás Antônio Gonzaga, com o título em que se contam as brejeirices de Fanfarrão, apresentava-se vestígio dessa mistura de ritmos populares, das festas dos batuques e a crítica que ele faz acerca dos movimentos corporais em que as pessoas dançavam e de uma certa rigidez no comportamento conservador e tradicional da época.

Ó dança venturosa! Tu entravas

Nas humildes choupanas, onde as negras,

Aonde as vis mulatas, apertando

Por baixo do bandulho a larga cinta,

Te honravam, c'os marotos e brejeiros,

Batendo sobre o chão o pé descalço.

Agora já consegues ter entrada

Nas casas mais honestas e palácios! (GONZAGA, 1786). 
Veja o quanto esses versos elucidavam o despertar sexual dos homens nesse período, ao presenciar a festa do batuque acontecendo, de forma espontânea e livre. Ou seja, esses ritmos musicais sexualizavam de fato essa imaginação dos homens da época, a ponto de rotular qualquer mulher que dançasse esse ritmo musical. A historiografia e manuscritos não deixam clara essa situação, mas nos levam a crer que esse ritmo musical despertava sim esse lado erótico da imaginação masculina.

Os divertimentos nos espaços perigosos, como batuques, siriri e cururu, eram condenados pela sociedade burguesa, uma vez que os hábitos finos deveriam prevalecer - como os saraus, considerados modelo a ser imitado pelo conjunto da população.

Sendo assim, qualquer manifestação popular, que não possuía característica sofisticada e fina semelhante às das elites locais, era considerada como das classes perigosas. Essa característica de classe perigosa foi apresentada pelo autor Challoub (1996), em sua obra Cidade Febril - Cortiço e Epidemias na Corte Imperial, no Brasil. O autor analisa como essas chamadas classes perigosas viviam na Cidade do Rio de Janeiro em suas vidas cotidianas. Essas análises de vivências sociais foram comparadas na obra da escritora inglesa Mary Carpetar, 1840, quando analisava o comportamento social das classes consideradas perigosas da Inglaterra, relacionando com as ações de criminalidade nas ruas.

Essas ações criminosas às quais Carpetar (1840) analisou seriam de pessoas consideradas pobres e miseráveis, que possuíam histórico de prisões por roubos, embriaguez, malfeitores; seriam pessoas que realizariam transações comerciais consideradas ilícitas, perturbação à ordem pública, envolvimento com prostitutas, nas ruas de Londres.

Em um outro ponto da análise social das classes perigosas da cidade de Londres, a autora Carpetar (1840) apresenta outros tipos de pessoas que viviam e conviviam nesse meio social, mas que preferiam viver de forma honesta, trabalhando em diversas funções nos comércios locais, mesmo ganhando muito pouco; ganho que era atribuído para o sustento de suas famílias numerosas e, também, para as práticas dos divertimentos.

Challoub (1996), ao se deparar com o texto da autora Carpetar (1840), observou os traços de semelhança dessa Classe perigosa da cidade de Londres com a da Cidade do Rio de Janeiro, verificando que ambas apresentavam traços fortes de semelhança nos aspectos da pobreza, miserabilidade, na criminalidade e até mesmo nas práticas de divertimentos ligadas a bebidas alcoólicas, mulheres prostitutas, comércio e criminalidade. Esses fatores sociais também se fizeram presentes na Cidade de Cuiabá em meados do século XIX. 
E essas práticas sociais das camadas mais pobres da sociedade eram vistas com muito desprezo e pavor pela elite local, pois, segundo as informações encontradas nos registros históricos, essas práticas sociais das classes pobres faziam com que a cidade se apresentasse de forma desorganizada, feia, suja, para outras pessoas que passassem por aqui, causando más impressões, a ponto de espalharem notícias negativas sobre o local.

Essas informações negativas espalhadas poderiam causar rejeições por parte de futuros moradores e investidores. Além dessas características negativas apresentadas, anteriormente, sobre as vivências das classes perigosas cuiabanas, não podemos deixar de mencionar que existia outra forma de manifestação social, que unia as duas classes elite cuiabana e classes perigosas - em um mesmo espaço urbano. Tal manifestação social refere-se às festas religiosas, voltadas aos Santos padroeiros da cidade, com a prática de devoção entre missa, rezas e procissão; ao seu término, abria-se um espaço para o divertimento e lazer, com bebidas, comidas típicas e danças típicas regionais.

Conforme citaremos a seguir, em alguns casos encontrados nos registros históricos, é possível observar que esses mesmos espaços - considerados como santos pela irmandade católica - eram divididos com outras práticas religiosas de matrizes africanas; como ocorreu no caso encontrado no ano 1874 e que foi denunciado pela Irmandade de São Benedito, sob acusação de práticas de bruxaria e feitiçaria ligadas à festa do brinquedo e do batuque, nos induzindo à reflexão de que essas festas eram consideradas preguiçosas, por causa de suas crenças e raízes africanas:

[...] o escravo Raymundo de propriedade de João dos Santos do Amaral, que se dizia feiticeiro e praticava a medicina natural, em sua casa era vista muitas pessoas para fazer curativos e banhos há base de ervas naturais, contra maus olhados e outras doenças corporais. Raymundo se dizia ser feiticeira faziam trabalhos de bruxaria de amarração de casais e reconciliação, também faziam trabalhos de vingativos, quando seus clientes solicitavam. Em sua casa também eram presenciados com frequência, festa do brinquedo em ritmo de batuques, regrada a muita comida típica africana e bebidas fermentadas com frutas e álcool.

O escravo Raymundo, faziam seus atendimentos, em uma casa bem simples localizada na travessa do Soído, próximo a Segunda Freguesia de D. Pedro II" (APMT, Secretária de Polícia, 1874 Lata B)

Nesse caso específico do escravo Raymundo, podem ser observados alguns fatores de repressão social ligados ao preconceito com suas raízes ancestrais. Os preconceitos passavam por ser ele negro, escravo, pessoa popular em sua comunidade e que praticava a medicina natural - prática que não era bem-vista pela elite burguesa da época - e, por último, por ser popular feiticeiro e se envolver nos problemas pessoais e de saúde de outras pessoas; reunia muitas delas em sua casa, demonstração de carinho feita através das festas do batuques/brinquedo. 
Dessa forma, existia uma preocupação com as práticas religiosas africanas existentes, tanto no Brasil como na cidade de Cuiabá, durante o Império, por causa da quantidade de escravos negros, que tornava mais fortes essas práticas religiosas ligadas ao divertimento do brinquedo/batuque e reveladas a partir de suas danças, feitiços e superstições.

Também, podemos ressaltar que as práticas dos divertimentos nos espaços considerados perigosos, no Distrito de Pedro II, não ocorriam em ambiente frequentado apenas por homens e mulheres populares de origem negra, escrava, forra e liberta, mas poderiam ser presenciadas, também, por oficiais e militares. Mesquita (1978), que analisou esses espaços festivos na cidade de Cuiabá, observando cada frequentador que estava no local, constatou existir homens e mulheres simples, bebendo e dançando na presença de autoridades policiais:

[...] O chefe de Polícia Dr. Santos Ferreira fez, neste dia, uma diligência ao Beco Sujo, onde se realizava o "batuque" e lá encontrou, a par de militantes e negros, vários guardas nacionais de boa extracção, que se irmanavam com os demais na esturdia e vadiagem (MESQUITA, 1978, p.70).

A região do Beco Sujo se localizava nas proximidades do Porto Geral e constituía local em que as ocorrências policiais eram frequentemente registradas, envolvendo brigas, embriaguez e ciúmes nas festas do brinquedo/batuques. Sendo assim, chama atenção a descrição que Alagranti (2010) faz desses lugares festivos, revestidos de música de batuque; ocasião em que as pessoas consumiam bebidas alcoólicas, faziam amizades ou, até mesmo, buscavam se relacionar de forma afetiva, estabelecendo relações humanas ligadas ao divertimento e à liberdade social nas cidades brasileiras. Ou seja, as pessoas frequentadoras desses ambientes festivos buscavam uma "liberdade", já que, muitas vezes, a sociedade os oprimia com tantas normas.

Diante desses fatos históricos e as atitudes descritas, ao longo deste artigo apresentamos um grupo de mulheres discriminadas e classificadas como boêmias, turbulentas, ébrias, prostitutas e vadias; imagem que possuíam diante da sociedade cuiabana, muitas das vezes, utilizada como defesa contra o estilo conservador que apregoa o papel da mulher como de quem deve viver somente para família, filhos, esposo e igreja.

Esse pensamento nos direciona a refletir como a sociedade cuiabana foi construindo seus limites territoriais, culturais, sociais e familiares de acordo com suas classes econômicas. Esse pensamento de liberdade de viver manifestado por mulheres simples se torna, nesse período, algo assustador, terrível e, até mesmo, ameaçador para o 
público masculino, que, desde a ancestralidade, sempre foi visto como autoridade maior em detrimento das mulheres.

\section{Considerações finais}

Acreditamos que todos os escravizados, libertos, forros, brancos pobres e indígenas desse período almejavam conseguir a tão sonhada liberdade para viver suas vidas de forma plena e justa perante a sociedade do século XIX. Para tanto, esses sujeitos históricos utilizavam-se de várias estratégias - "curva-se a face presente do obscuro ou até mesmo o turvo levantar a voz", almejando impor sua presença e limite social, como fez o poeta Condoeiro, ao expressar sua vontade de liberdade por meio do poema Confidência. É o desejo de reaver o domínio sobre seu corpo e sobre sua sexualidade, seja homem, seja mulher. Vivendo no sistema de cativeiro ou sendo explorados e humilhados, muitos escravos, forros, libertos, criolos, indígenas e brancos pobres enfrentaram o sistema social ao tentarem conquistar suas liberdades morais, financeiras, familiares, de lazer e de divertimento.

Nesse sentido, este estudo buscou compreender a construção da identidade negra escravizada, liberta, forra, indígena e branca pobre a partir das relações sociais presentes naquele tempo. A busca pelas vidas noturnas e diurnas das mulheres negras escravas, forras e libertas trouxe à luz a existência de uma visibilização da população negra, o que podemos chamar de visibilidade invisível. A partir dela, em relatos e informações sobre essa população, foi possível encontrar o seu modo de viver, trabalhar e de se divertir em seus momentos livres.

Diante dessa realidade, a discussão acerca das festas realizadas nos bares e nas tavernas, na região de Pedro II, em Cuiabá, buscou objetivar e mostrar o quanto esses locais também representaram um espaço de resistência e luta em busca da liberdade plena, durante o período pesquisado.

\section{Referências}

\section{Livros:}

ALGRANTI, Leila Mezan. Honradas e Devotas: Mulheres da Colônia condições femininas nos conventos e recolhimentos do sudeste do Brasil 1750-1822. Orientador: . 1993. Número de folhas. Tese (Doutorado em História) - Faculdade de Filosofia e Ciências Humanas nome da universidade, local, 1993. 
ASSIS, Edvaldo. Mato Grosso: Negro Forro\& Sociedade Escravocrata. Diário OficialSuplemento Mensal do dia 31 de julho de 1986.

COMETTI, Pe. Pedro (SDB) Apontamentos da História Eclesiástica de Mato Grosso Paróquia e Prelazia Volume I. Instituto Histórico geográfico do Mato Grosso e Academia Mato-grossense de Letras, Cuiabá, 06 de dezembro de 1996, p. 12.

INOUI, Simone Zanelatti de Cubas. Sobre o vestuário e suas representações na Vila Real do Senhor Bom Jesus do Cuiabá (1727-1818). Dissertação (Mestrado em História) UFMT/ICHS, 2004.

GONÇALVES FILHO, Carlos Antônio. Honradas senhoras e bons cidadãos: gênero, imprensa e sociabilidades no Recife oitocentista. Dissertação (Mestrado em História) UFPE.

MESQUITA, José Barnabé. Gente e coisas de antanho (1978). Mina (século XVIII). AfroÁsia, Rio de Janeiro, v., n. 37, p. 43-73, mês, 2008.

MOURA, Denise. Saindo das Sombras: homens livres no declínio do escravismo. Campinas: Área de Publicações CMU; UNICAMP, 1998, p. 40.

REIS, João José. Tambores e Tremores: A Festa Negra na Bahia na primeira metade do Século XIX. In: CUNHA, Maria Clementina Pereira (Org.). Carnavais e Outras F(r)estas. Ensaios de História Social da Cultura. 1 ed. São Paulo: UNICAMP; CECULT, 2002.

SENA, Divino Marcos de. Camaradas e complexidade entre livres e pobres: Mato Grosso - primeira metade do século XIX, descreve essa categoria de pessoas em suas atividades laborais pela cidade.

STANLEY, J. Stein. Vassouras, 1949. Rio de Janeiro: Folha Seca, 2007.

VOLPATO, Luíza Rios Ricci. Cativos do sertão: vida cotidiana e escravidão em Cuiabá 1850-1888. 2ª ed. São Paulo: Marco Zero, 1993.

\section{Arquivos:}

APEMT-Arquivo Público Estadual de Mato Grosso. Assembleia Legislativa do ano de 1888, $\mathrm{n} \stackrel{0764 .}{2}$

APEMT-Secretária de Polícia, crime prática de feitiçaria. Ano 1874, Lata B.

Decreto no 577. Postura Municipais de Cuiabá. Cuiabá 30 de novembro de 1880. IMPL-

Livro de Registro dos Decretos e Resoluções.

INVENTÁRIO - Cartório do $2^{\circ}$ Oficio- Serviço Notarial e Registral da $1^{\circ}$ Circunscrição imobiliário da Comarca de Cuiabá Estado de Mato Grosso. Argemisa de Campos Figueiredo. Transcrição 41.055 as fls 219 do livro 3-AD em 04/05/1970. Matricula 15.822 as fls, 017 do livro 2-BE em 04/09/1980. Matricula 24.866 as fls. 124 do livro 2-CO em 28/05/1982.Transcrição: 35.957 as fls. 065 do livro 3-AB em 23/02/1968. Transcrição: 44.878 as 212 do livro 3-AH em 12/12/1971. 


\section{Periódico:}

O PORVIR. Vício do Jogo- oㅡ 25. Cuiabá 15 de dezembro de 1877/15/dez. APMT- Coleção de Jornais. 


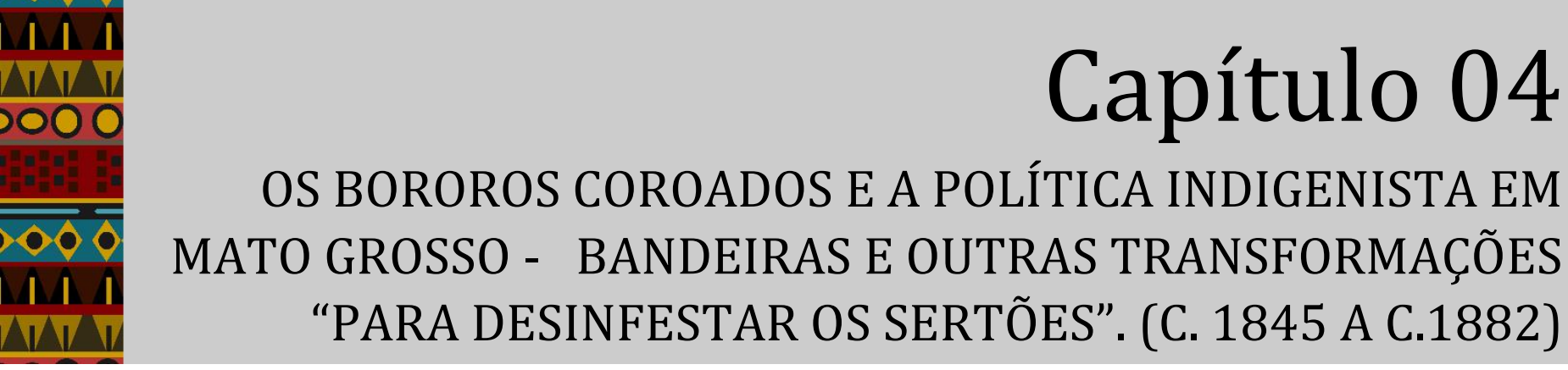

\section{ERNESTO CERVEIRA DE SENA}

Em maio de 1845, o presidente da província de Mato Grosso, Ricardo Gomes Jardim, enviara uma "bandeira" para "desinfestar as cabeceiras do Rio São Lourenço", onde residiam os indígenas bororos coroados. Justificava a iniciativa a partir de uma suposta necessidade de encontrar alguma vereda sobre a qual se construiria uma "nova estrada" até a região do "Paraná", de onde se ligaria até São Paulo. Daí, a mesma bandeira seguiria para a região da antiga estrada de Goiás, para "afugentar" os índios Caiapó. Essas medidas, para o presidente, em comunicação com o ministério do Império, seriam executadas "mui facilmente e pronto". O mesmo governante também não achava muito difícil estabelecer colonos nas estradas que pretendiam construir, uma vez que a expedição beligerante retirara os indígenas de seu território ${ }^{47}$.

Acontecia que o termo "bandeira" remetia aos tempos de colônia, quando Mato Grosso e outras regiões foram conquistadas pelos portugueses frente aos vários grupos indígenas que habitavam a área, além da coroa rival, a espanhola. Se, no tempo de colônia, o termo remetia à preação de indígenas e busca de riquezas ${ }^{48}$, no século XIX, a palavra referia-se às expedições bélicas, constituídas para ataques aos indígenas ou para destruir quilombos de negras e negros escravizados, os quais, por sua vez, também tinham relações com grupos ameríndios para se manterem e resistirem às investidas armadas dos luso-brasileiros (ver Rodrigues, 2019).

Nesse mesmo ano de 1845, ou seja, da carta de Gomes Jardim, o governo central decretara a proibição das "bandeiras". Passaram a ser consideradas, oficialmente, como "desumanas" e "ineficazes" para tratar os grupos indígenas. Tal interdição a esse tipo de expedição apareceu em meio a uma série de medidas do governo central, procurando unificar as ações nas províncias, visando incorporar os ameríndios às políticas de Estado.

\footnotetext{
47 Arquivo Público de Mato Grosso (APMT). Registro de Correspondência do Governo com o Ministério dos Negócios do Império. Ano: 1843-1847. De Ricardo José Gomes Jardim para José Carlos Pereira de Almeida Torres, Ministro do Império. 21 de maio de 1845.

48 Como, por exemplo, a que fora enviada pela Vila do Cuiabá para castigar os bororos em 1780. "Anal de 1780. Apresentado em Câmara pelo vereador Manoel José de Azevedo", em Janaina Amado e Leny Anzai (2006).
} 
Isso acontecia depois de muitos e calorosos debates envolvendo políticos e intelectuais do Império do Brasil, quando discutiram desde a existência ou não da "humanidade" silvícola até a maneira mais eficaz de abordarem os distintos grupos, expressadas pela assimetria entre "persuasão" e "brandura" e a "força" (Ver Cunha p. 134-137). Chegou-se a uma solução - longe de ser unânime entre políticos e pensadores - de que deveria haver uma política única em relação aos indígenas, preconizando a "catequese e civilização" dos grupos indígenas em todo o império, substituindo qualquer diretriz regional antes existente (Sampaio, 2009, 178-179). A nova política não deixava de ser inspirada nas memórias das reduções jesuíticas e no posterior "Diretório dos índios", instituições coloniais aparentemente mais persuasórias do que conflitantes aos ameríndios. Assim, com o regulamento de 1845, também deveria haver uma "Diretoria dos Índios" para coordenar os trabalhos em cada província e os aldeamentos estabelecidos seriam geridos, preferencialmente, por padres de ordens, como os capuchinos e os carmelitas, passando a ter suas atividades missionárias a serviço do Estado. Além dos padres, essa gestão também se daria por cidadãos considerados qualificados - com poder de polícia - para tratar com os indígenas (Ver Sampaio, 2009, 188-193; Almeida, 2008).

Dessa forma, a "catequese e civilização" pretendia, em resumo, reunir várias etnias em novos aldeamentos, o que acarretava retirar os indígenas de seu modo e local de viver, de sua "autonomia ecológica", como se refere Navarrete (2008). Como nos mostra o mesmo autor (2015), sobre as várias áreas nas Américas e os ameríndios, povos indígenas eram desterritorializados de sua "rede de vida", ou seja, de onde participavam da mútua dependência entre os seres vivos e da determinação dos chamados "recursos naturais", para serem unidos e integrados ${ }^{49}$; o objetivo era, em seguida, prepará-los, por força do Estado, para trabalhos em oficinas e, sobretudo, na lavoura, de maneira que pudessem produzir para o mercado e também para a autossuficiência alimentar na nova área delimitada pelas autoridades nacionais. Era previsto que essa mesma área poderia, mais tarde, ser alienada para pessoas privadas, enquanto a própria terra que deixavam ao serem aldeados eram dispostas pelos promotores da "civilização". Conforme Cunha, a "catequese e civilização" era antes uma forma para o avanço sobre terras indígenas. Em Mato Grosso, ao lado de nova expansão sobre territórios ameríndios, governantes, fazendeiros e outros da sociedade envolvente também ansiavam por dispor dessa possível mão de obra "domesticada" para atender suas demandas nas fazendas, chácaras e urbis 50 . Inclusive,

\footnotetext{
49 O autor utiliza-se (como aponta) da formulação geográfica de Harvey (2009).

50 Para Patrícia Melo Sampaio (2009, p. 196), não havia uma hierarquia nítida de interesses diferindo as terras indígenas e a fonte de mão-de-obra, pois eram questões conectadas no Império do Brasil.
} 
como veremos, chegou-se a pensar em formar cidades com os indígenas quando supostamente transformados pelos aldeamentos, talvez tendo como recordação de como fora a constituição de outros lugares no período colonial ${ }^{51}$, como Vila Maria, atual Cáceres em Mato Grosso 52 .

De toda maneira, quando sai a proibição das bandeiras, em 1845, era claro que governantes e cidadãos em Mato Grosso estavam em plena ação para tomar as terras bororos no Alto São Lourenço, sem maiores considerações sobre os ameríndios, como as que tinham feito publicar as novas diretrizes. Talvez houvesse a ideia de que o regulamento fosse tão somente mais uma "lei”, que não, necessariamente, dever-se-ia cumprir. O próprio presidente Gomes Jardim tinha relações com um chefe político local que amiúde desafiava as leis do império enquanto mantinha posição hegemônica frente a outros grupos políticos provinciais e funcionários do Império (ver Sena, 2009). No entanto, as bandeiras continuaram a acontecer e foram usadas notadamente contra os bororos coroados. Ao contrário do que pensava o presidente Gomes Jardim, não foi "mui facilmente e pronto" desalojarem os coroados de seu território e circunscrevê-los aos ofícios da sociedade envolvente. Pelo contrário. Em uma contraofensiva indígena, em 1849, o filho do próprio presidente de província na ocasião, José da Costa Pimentel, o tenente Costa Pimentel, foi morto quando sua comitiva viajava para Cuiabá. A inconformidade dos bororos também se expressou na queima de estabelecimentos rurais e matanças do gado cuja criação se expandia, muitas delas, por novas áreas mato-grossenses, consideradas amiúde como "vazias" ou "desertas" - tal qual acontecia em outras partes da América, como na Argentina nas décadas de 1870 e 1880, quando forças armadas nacionais guerrearam contra numerosos indígenas, tomando-Ihes o solo e exterminando-os, em uma movimentação conhecida como "Campanha do Deserto" (entre outros, ver Mallon, 2011).

Em Mato Grosso, ainda em 1849, com as notícias sobre mortes e "correrias" dos indígenas bororos, foram organizadas, prontamente, "três bandeiras de 50 homens cada uma. Elas tinham o objetivo declarado de "exterminar absolutamente semelhantes feras" (grifo meu), comunicava o presidente de Mato Grosso em ofício ao Ministro do Império. Na mesma comunicação, era requisitada verba para continuarem esse tipo de empreendimento ${ }^{53}$. A reposta do ministro foi lapidar sobre a política pretendida pelo governo central, a qual não se alteraria substancialmente nas próximas décadas por outros representantes do governo central: os gastos com os indígenas seriam somente "para a

\footnotetext{
51 Ver Almeida, Maria Regina Celestino (2010, pp. 13-118).

52 Entre outros, ver Volpato (1987) e Moreira da Costa (2006).

53 Arquivo Nacional. IJJ(9) 507. João José da Costa Pimentel para Visconde de Monte Alegre, ministro do Império. Cuiabá, 6 de outubro de 1849.
} 
catequese e civilização" e "jamais" para o envio de "bandeiras", como já havia providenciado o chefe do Executivo local. Acrescentava, ainda, que o presidente Pimentel deveria se abster "de emprego de tais meios, ficando na inteligência de que só é lícito o emprego da força para repelir os ataques" dos indígenas, "e nunca para provocá-los". ${ }^{54}$

O presidente posterior a Pimentel, o então capitão Augusto Leverger, replicava as determinações da corte no Rio de Janeiro em seus discursos. As bandeiras eram condenáveis, "seja por recomendação imperial, seja por falta de humanitarismo", além de apresentar absoluta "falta de eficácia nos resultados"55. Diante dos "ataques" dos indígenas, dizia estar sem força policial para ir em "auxílio dos moradores" dos distritos; ao mesmo tempo, preconizava que os habitantes das regiões do interior deveriam ficar advertidos, mas "nunca matá-los, sem aprovação", como antes acontecia, o que somente dava lugar a uma "interminável série de represálias" 56 .

Apesar das palavras do presidente, os projetos de "ocupar áreas vazias", promover colonizações, abrir estradas e angariar mão-de-obra continuavam. Por outro lado, os ataques dos bororos coroados se intensificavam. Em 1856, Leverger destacava que as investidas dos coroados se agudizavam, promovendo "mortes, roubos e incêndios", mesmo em sítios "não muito distantes desta capital". Dessa maneira, o capitão dizia que, apesar de sua "repugnância pela expedição de bandeiras", era "urgido pelo clamor público" e pelas participações do chefe de polícia, tendo, então, que aprovar a saída de outra dessa espécie de campanha. Dizia que o resultado fora como receava: despesa excessiva e o não alcance do objetivo de "escarmentar os índios de modo que, ao menos, por algum tempo, ficássemos sem receio das suas correrias" 57 . E voltava a insistir que os moradores "de lugares infestados" deveriam ter "prudência e cautela" e que não deixassem "suas habitações desprovidas de todo o meio de repelir as agressões dos selvagens, que certamente seriam menos afoitos se encontrassem alguma resistência"58. Aqui, a "resistência" deixava de ser dos coroados, passando a ser dos que viviam nas chácaras e fazendas.

Outras "bandeiras" foram organizadas, mas não poderiam expressar o caráter bélico, como a enviada por Souza Osório, em 1857, com o intuito de sequestrar mulheres e

\footnotetext{
${ }^{54}$ Arquivo N.acional. IJJ(9) 507. Monte Alegre para José da Costa Pimentel, presidente da província de Mato Grosso. Corte, 15 de junho de 1850

${ }_{55}$ APMT. Relatório de Presidente de Provínvia. RPP. Augusto Leverger, 10 de maio de 1851, p. 6.

${ }^{56}$ APMT. RPP.Leverger talvez seja o único dirigente nesta época em Mato Grosso que via a violência como desencadeador de uma série de represálias intermináveis, no entanto, ao que parece, não reconhecia que os afazendamentos e os preparativos para a nova estrada atingiam brutalmente os indígenas do Alto São Lourenço.

${ }^{57}$ RPP. Augusto Leverger. Cuiabá, 4 de dezembro de 1856, p. 6.

58 Ibidem, p. 17.
} 
crianças e entregá-las a famílias da cidade para que fossem "civilizadas". Difícil imaginar que o sequestro de integrantes de um grupo não fosse um ato de violência. Não o seria debaixo da bandeira fictícia da "civilização". De toda forma, foi com coroados sequestrados como esses, crescidos em meio aos citadinos, que fizeram uma expedição em 1886 para "pacificar" os bororos, quando conseguiram finalmente vencê-los para dar início ao processo de seus aldeamentos. Antes disso, o termo "bandeira" foi sumindo do vocabulário para lidar com os indígenas, mas continuava a ser designação para expedição destinada a destruir quilombos, como foi a enviada por Leverger, em 1854, ou outra enviada pelo presidente Antônio Pedro de Alencastro em 1861.

Se colonos, fazendeiros e governantes se projetavam sobre as áreas bororos, fosse para viabilizar a estrada para São Paulo, fosse para ocuparem mais terras e adquirirem mão-de-obra, os bororos coroados, notadamente na década de 1870, fizeram o caminho inverso, chegando a atacar cada vez mais áreas já perto da capital, Cuiabá. Na verdade, a região em que estava Cuiabá, antes de sua fundação nas primeiras décadas do século XVIII, era território dos coroados. Quando estavam localizados no São Lourenço, muito de sua rede de vida já tinha sido dilapidada pelos paulistas e, agora, também continuava na mira dos nacionais (ver Moreira da Costa, 2019, p.88). Por outro lado, os bororos coroados foram um dos grupos indígenas na fronteira Oeste que mais aguerridamente lutaram para manter suas formas de viver frente à expansão dos "brancos" (ver Moreira da Costa, 2019, p. 87). Assim, na década de 1870, os ataques responsivos dos coroados passaram a fazer parte dos relatórios dos presidentes de província na parte em que depositavam grande atenção, a da "Segurança Pública", não mais na "catequese e civilização" ou em "Índios", como outrora.

A ação da sociedade envolvente contra os "vândalos silvícolas" consistia basicamente em enviar forças para os locais onde se davam tais ataques. Dessa maneira, não conseguiam um confronto mais incisivo contra os indígenas, pois esses já tinham se dispersado há muito, quando as forças chegavam ao local. Por vezes, organizavam-se rondas preventivas, mas que também não surtiam os efeitos desejados. Ao mesmo tempo, ainda não se sabia com precisão quando e onde os indígenas iriam atacar. Em 1878, um dos anos mais tempestuosos, os indígenas mataram 56 pessoas, segundo registro oficial ${ }^{59}$. Nesse mesmo ano, excetuando-se a ação dos aborígenes, foram assassinadas 17 pessoas na província. ${ }^{60}$ Desse modo, os ataques indígenas agudizavam o medo em quem teria não

\footnotetext{
59 Secretaria da Polícia da Província de Matto-Grosso em Cuyabá, 1881, chefe de polícia João Maria Lisbôa, p. 7, anexo ao RPP. Barão de Maracaju. 1881.

60 RPP. João José Pedrosa, 1878, p. 10.
} 
só de passar por áreas sem cidades ou vilas, mas também para quem se encontrava em pequenos povoados e propriedades rurais.

Somava-se às notícias de morticínio, que causavam horror aos mato-grossenses, o pouco desenvolvimento econômico, que também entrava na conta dos indígenas. Assim, um presidente considerava desestimulante aos agentes econômicos investir em uma plantação quando ela estaria sempre sob a possibilidade de um ataque ${ }^{61}$. Nesse mesmo sentido, dizia um redator do jornal "A Província de Matto-Grosso": "Daqui a causa porque a lavoura definha e fenece, em luta (...) com dois inimigos que the vão enfraquecendo as forças, os silvícolas e a falta de braços", o que acarretava a falta de empreendimentos "que possam trazer-nos a seiva da vida!"62

Somente as forças policiais e os voluntários da capital não conseguiriam o intento de pacificar ou repelir os que obstaculizavam a "seiva da vida". Dessa forma, o tenente-coronel da Guarda Nacional, Celestino Corrêa da Costa, disponibilizou treze dos seus camaradas a fim de comporem as "turmas". 63 Pela documentação, não é possível saber o quanto eram beligerantes essas "turmas". Contudo, quando uma expedição descontentava o presidente, ele resgatava a antiga interdição às "bandeiras", como a do capitão Bueno, chefe dos terena ${ }^{64}$ - apontada como uma das mais "belicosas", "desumanas" e "já condenadas pelo governo Imperial". Isso só fazia aumentar ainda mais a ira e o desejo de vingança dos "selvagens". 65 Como vários outros dirigentes, na província ou no centro administrativo e político do Império, apontava para a panaceia etnocêntrica, típica do tempo e lugar, que resolveria a situação: "a maneira de extirpar o mal em definitivo" seria "somente pela catequese desses selvagens, cujos atos de perversidade" deveriam "ser atribuídos ao completo estado de embrutecimento em que vivem, e do qual nos cumpre tira-los à bem nosso e da humanidade."66 Como mostra Sampaio, se as disposições legais pouco mudaram depois de 1845 em relação aos indígenas, houve a defesa de que a direção geral dos índios e a chefia das aldeias, constituídas pela mesma diretoria nas províncias, deveriam ser confiadas a clérigos, não a civis; essa tese era reforçada pelas várias denúncias sobre incorreções e abusos em muitas partes do Brasil e pela maneira ineficiente

\footnotetext{
61 RPP. Barão de Maracaju, 1880. p. 40.

62 Núcleo de Documentação Histórica. “A Província de Matto-Grosso”, 16 de fevereiro de 1879.

63 APMT. RPP. Barão de Maracaju. 1880, p. 8.

64 Segundo o presidente Gomes Jardim, era "costume antigo" fornecerem títulos de capitão para caciques, embora pouca valia teria para eles. APMT. Registro de Correspondência do Governo com o Ministério do Império. Ano 1847. De Ricardo José Gomes Jardim para José Carlos Pereira de Almeida Torres, Ministro do Império. Para Vasconcelos (1995, p. 127),m uitos caciques, após a guerra do Paraguai, ganharam títulos militares como recompença pela atuação no conflito do Prata.

65 APMT. RPP. João José Pedrosa, 1878. p. 35.

66 APMT. RPP. João José Pedrosa. 1878. p. 9. ou outro exemplos com a mesma opinião, RPP. Hermes Ernesto da Fonseca. 1876. p. 21. Pimentel, p. 14.
} 
como eram administradas. Por outro lado, em muitos lugares, também se reclamava da falta de padres para o trabalho com os indígenas. Na verdade, não se perdia a perspectiva da "civilização", pois a "catequese" era vista como a parte substancial para a transformação pretendida do indígena. Enfim, "catequese e civilização" era o lema e o leme da direção que procurava tratar de conquistar "dois terços" do território imperial (e suas gentes) ${ }^{67}$.

$\mathrm{Na}$ enorme província de Mato Grosso, considerada amiúde pouco povoada (o que era um dos obstáculos à civilização, diziam), as discussões e prognósticos também eram registrados pelos líderes políticos da região. E também serviam para alfinetadas de contendores políticos. Barão de Diamantino, um dos chefes do Partido Conservador de Mato Grosso, o qual fornecia suporte e era apoiado pelo então presidente de província, previa que os indígenas, quando "civilizados", seriam, "sem dúvida, os melhores roteadores das nossas imensas florestas, que um dia poderão converter-se em cidades populosas". ${ }^{6}$ Entretanto, o jornal oposicionista desse momento não deixava em branco a constante reclamação das autoridades sobre a falta de padres catequizadores, os principais responsáveis pelo trabalho de transformação dos índios em "roteadores". 69 Desse modo, o periódico O Liberal lembrava que, em uma província tão necessitada de sacerdotes, havia um padre que se ocupava mais de seus negócios pecuniários do que das carências espirituais de quem habitava o Mato Grosso ${ }^{70}$. O padre a que se referiam era Ernesto Camilo Barreto, outro dos líderes dos conservadores na província. Essas contendas políticas, de toda forma, ao que parece, não mudavam ou impunham novo rumo ao que já era estabelecido pela Corte do Império, nem reformavam acentuadamente as medidas que vinham sendo adotadas provincialmente.

\section{Bater os índios}

Quando o general Rufino Enéas Gustavo Galvão, o Barão de Maracaju, assumiu a presidência (dezembro de 1879/maio de 1881), certamente trazia consigo as recomendações imperiais de "catequese e civilização". No entanto, também tomava contato com relatos produzidos na província, como este de fatos ocorridos todos em menos de 24 horas. Segundo o registro:

“(...) ataque de índios coroados no distrito de Brotas. Aí os silvícolas atacaram

\footnotetext{
67 Ver Sampaio (2009, p. 197)

68 APMT. Fala do Vice Presidente de Província. Barão de Diamantino. 1875, p, 12.

69 Por exemplo: RPP. Barão de Maracaju, 1881, p. 27; João José Pedrosa, 1878, p. 33.; RPP. Maria José de Alencastro. 1881, p. 53.

70 NDHIR. "O Liberal". 26 de julho de 1875.
} 
as casas dos agregados de João Pinto de Figueiredo e aí mataram dois homens, três mulheres e cinco crianças. No mesmo dia, assassinaram "dois homens, e frecharam no peito uma mulher, nas proximidades da freguezia de Santo Antônio do Rio-Abaixo, a seis léguas da capital. Em número mais considerável, mas ainda no mesmo dia, outros selvagens também da família dos indomáveis Coroados, atacaram o sítio do cidadão Joaquim Pereira de Almeida, distante cinco léguas da Vila do Rosário, e barbaramente assassinaram-lhe uma filha casada e duas outras menores, roubando e destruindo tudo quanto encontraram. Já de retirada mataram mais duas mulheres e cinco crianças que fugiam aterrorizadas." 71

Se o Barão de Maracaju, em sua juventude, acompanhou os debates entre Varnhagen e Gonçalves Dias, pode ter pensado em algum momento, durante sua presidência, algo parecido: "Varnhagen tinha razão, não há como esses bárbaros serem símbolo de uma nacionalidade, eles são, isso sim, uns subversivos da ordem..."

De qualquer maneira, no relatório do Barão de Maracaju, como no de qualquer outro que se apoiava em uma governabilidade, percebe-se que os dirigentes não eram impermeáveis aos clamores da população não indígena sobre a necessidade urgente de se colocar um fim às agressões dos indígenas. Entretanto, ao mesmo tempo, suas ações e falas deveriam apresentar-se com "as vistas do governo" central, ou seja, conforme as diretrizes e designações saídas da Corte $^{72}$. Desse modo, ao mesmo tempo em que o presidente dizia, por vezes, aos políticos e populares que não se devia "desesperar dos meios brandos", ele também percebia, como os seus interlocutores, que as maneiras de proceder do governo não estavam surtindo o efeito esperado ${ }^{73}$. O presidente barão de Maracaju, então, propôs novas medidas oficiais. As rondas seriam mais ostensivas, não apenas preventivas, e as excursões, que praticamente se restringiam a ir ao encalço dos indígenas depois dos ataques, iriam agora até as habitações dos silvícolas, antes do período de ataque ${ }^{74}$. Se essas expedições também se ressentiam da falta de padres catequizadores em sua composição, algumas levavam consigo um grande trunfo, indígenas bororos, provavelmente os mesmos que foram sequestrados e levados para casas urbanas anos antes. De toda forma, eram tidos como ótimos trilheiros, além da língua dos coroados lhes serem bem familiar. Para esse maior vigor às expedições e rondas, o presidente abriu um crédito extraordinário de 25 contos de réis, junto ao Ministério do Império. Além disso, foi recomendado que os habitantes dos distritos sujeitos às agressões dos índios ficassem

\footnotetext{
71 APMT. RPP.. Barão de Maracaju, 1880, p.4.

72 Era uma expressão de Paulino Soares de Souza, em seu Direito Administrativo, o qual Ilmar Mattos utiliza para traçar a "teia de Penélope", em última instância, a qual ligaria o governo central com as províncias, de maneira que nunca se completava totalmente.

${ }^{73}$ APMT. RPP. Barão de Maracaju. 1881, p. 7.

74 Os dirigentes haviam chegado à conclusão que os índios faziam suas peregrinações depredatórias, principalmente em direção à capital, no período das chuvas, ou seja, de outubro a março.
} 
vigilantes e "se estabelecerem mais próximo possível uns dos outros"75. Formariam grupos, de pelo menos seis pessoas, a fim de poder defender-se, mutuamente, contra qualquer possível ataque dos silvícolas. Parecia que o fato de não se conseguir estabelecer relações de amizade não era mais uma culpa exclusiva dos habitantes da área rural.

Junto com essas novas medidas, apareceu um "novo" termo, um verbo, publicado em relatório, transcrito e comentado em jornais da província. Um termo que seria relacionado a uma prática: "bater". Esse verbo, a princípio, surgiria conjugado de maneira antagônica a um outro que vinha sendo utilizado: "civilizar". No dicionário mais usado no século XIX, o "Moraes", "bater" significava vencer, derrotar ${ }^{76}$. Era, portanto, guerra. No entanto, era guerra que não deveria ser explicitada nas correspondências. Em outro dicionário, das últimas décadas do Império, que se propunha a dar designações não encontradas em outros compêndios sobre a língua no Brasil, relaciona o termo "bater" a uma única significação: "correr"77. A aparente ambivalência do termo poderia camuflar os propósitos de derrotar os indígenas nas armas, mas tanto o antigo "correr" os índios quanto as "correrias" dos próprios indígenas eram termos que também remetiam a embates bélicos. Enfim, "bater" os índios era derrotá-los nas armas.

Dessa maneira, as rondas promovidas pelo presidente da província e cidadãos "ilustres", que dispunham de camaradas, deveriam percorrer áreas próximas da capital, como o Morro Grande e a Forquilha, estando incumbidas de procurar os locais onde os índios "se arranchavam" e "batê-los", quando os encontrassem. Da mesma forma, as forças que percorriam os trechos entre o Morro Grande e a Guia também deveriam "bater as partidas de índios que encontrassem"78.

Essas recomendações, assim como a notícia de organização de expedições que iriam até o Alto São Lourenço em busca das "malocas" dos coroados, foram publicadas em jornal como atos oficiais. Por essa mesma época, um praça de um destacamento fora morto

\footnotetext{
${ }^{75}$ APMT. RPP. Barão de Maracaju, 1881, p.8.

${ }^{76}$ Segundo o dicionário "Moraes", de 1813, o termo "bater", além de fazer correspondência à ação de martelar etc., referese também às ações belicosas: "Verbo ativo, dar golpe com martelo, (...). Bater o muro, ou praça com artilharia, ou outros engenhos. 'Vi...espedaçar navios, e bater muros”. Exame de artilharia, 'Quinze galés lhe bateram o seu galeão'. Bater-se: brigar com espada. Bater de camaradas: disparar a artilharia lentamente." $C f$. "Diccionário da Língua Portugueza recopilado dos vocábulos impressos até agora, e nesta Segunda edição novamente emendado, e muito accrescentado, por ANTONIO DE MORAES SILVA, natural do Rio de Janeiro, offerecido ao muito alto, e muito poderoso príncipe regente N. Senhor.” Lisboa: Tipographia Lacerdánia, 1813.

${ }^{77} C f$. "Dicionário Brasileiro da Língua Portuguêsa - Elucidário Etimológico Crítico, das palavras e frases que, originárias do Brasil, ou aqui populares, se não encontram nos dicionários da língua portuguesa, ou nêles vêm com forma ou significação diferente (1875-1888), pelo doutor ANTONIO JOAQUIM DE MACEDO SOARES, coligidido, revisto e completado por seu filho Julião Rangel de Macedo Soares.” Rio de Janeiro: MEC/INL, 1954.

${ }^{78}$ NDHIR. “A Província de Matto-Grosso”. 15 de março de 1881.
} 
pelos "indomáveis coroados". Um periódico "dedicado aos interesses da Província" comentou a morte do soldado destacado e as providências tomadas assim:

\begin{abstract}
"Não resta, à vista disso, esperança de atraí-los à civilização por meios suasórios, como bem se depreende do procedimento hostil que acabam de ter para com aquele destacamento(...). Antes de receber esta comunicação, já S. Ex., o Sr. Presidente da província havia expedido ordem para aquele comandante [...]para providenciar sobre o fornecimento de $\mathbf{5 0}$ cidadãos armados que seguirão para cada um daqueles pontos [o destacamento em Ponte da Pedra e o Alto São Lourenço], a fim de ir às malocas de índios, incorporados aos respectivos destacamentos, logo que terminar a estação das chuvas."79
\end{abstract}

Essa notícia demonstra, antes de tudo, a descrença (que já deveria predominar entre os citadinos apesar dos discursos dos presidentes) na possibilidade de "se chamar à civilização" os "indomáveis coroados". Contudo, o notável é que o redator, incorporando o espírito de uma população que não suportava mais tamanho horror advindo dos indígenas, via, finalmente, nos atos oficiais publicados, uma concordância com esse mesmo ânimo. Ao enviar força para "bater" os coroados, parecia, ao redator, que o presidente abandonava os meios "suasórios" e "cristãos", fugindo das "vistas do governo central", ou seja, das designações emanadas no governo central.

O presidente, por outro lado, em seu relatório, procurou mostrar que suas medidas eram novas, mas que mesmo assim não deixavam de estar de acordo com o que era preconizado pelo governo central. Assim, seu objetivo último era catequizar o bravio e ponderou o que se noticiava nos jornais, sem citá-los diretamente. Sobre a morte de soldado em destacamento, dizia que este teria saído sozinho e sem seguir os protocolos recomendados, o que the ocasionou a morte. Isso acontecera em outras ocasiões com outros soldados, ao não cumprirem "as terminantes ordens estabelecidas" de não se afastar "desarmados de seu destacamento" .80 O destaque que o presidente prestava à morte desse soldado e à explicação dessa acontecera, ao nosso ver, para frisar que não teria ocorrido confronto armado, já que a vítima estaria isolada do pelotão. Também serviria para não desacreditarem das defesas armadas, cujo recrutamento quase sempre fora crítico. Acontecia que, se o soldado tivesse sido morto em confronto direto, haveria indícios de que a política de "persuasão" e a consequente "civilização" não era praticada.

\footnotetext{
79 NDHIR. "A Província de Matto-Grosso", 27 de março de 1881.

${ }^{80}$ APMT. RPP. Barão de Maracaju. p.10.
} 
Assim, para o presidente, "bater", portanto, não deveria significar derrotar os índios em guerra, teria que significar afugentá-los para dentro das matas. O presidente cita o resultado das expedições à região do alto São Lourenço como exemplos do que queria das expedições ou do que poderia ser mostrado ao governo central (todos os relatórios, como sabemos, eram enviados para a corte no Rio de Janeiro): uma, a do major Jorge Lopes da Costa Moreira, "afugentou para longe os índios coroados que habitavam dois aldeamentos situados sobre as margens dos rios Águas Brancas e das Pratas, confluentes do S. Lourenço."; outra, talvez o principal exemplo, fora comandada pelo alferes José Duarte e levava consigo bororos (não sabemos se eram coroados) para direcionar a trilha e serem a linha de frente ao abordar os indígenas. De tão exemplar, o presidente citou quase integralmente o relatório dessa expedição. Vale citar aqui também algumas partes da narrativa do alferes:

\begin{abstract}
"[Após ter saído da fazenda do Sr. José Goes Miranda], depois de 11 dias e uma noite de viagem e sofrimentos, por lugares intransitáveis, por elevadas montanhas, deparei com um aldeamento na margem direita do rio $S$. Lourenço, perto de uma grande cachoeira, e de conformidade com as instruções que recebi, pus o aldeamento em cerco, às três horas mais ou menos da manhã, e ao alvorecer ordenei aos índios bororos que entrassem no aldeamento e fizessem a fala aos silvícolas, conforme as recomendações de V. Exc..Porém, logo ao se aproximarem das casas, foram cometidos por eles, que os procuravam ofender com as flechas, vendo então o perigo a que estavam expostos não só os bororos como a força sob meu comando, à vista do caráter agressivo dos selvagens, os mandei atacar de maneira a não ser ofendida praça alguma; depois então de pequena resistência retiraram-se, ocasião esta em que empreguei todos os esforços que me foram humanamente possíveis, afim de conter a força, para que não cometessem ato de desumanidade para com os selvagens, conseguindo por isso aprisionar o número de 17, sendo 5 mulheres e 7 meninas, os quais se acham debaixo de guarda" 1
\end{abstract}

Para a infelicidade do redator de "A Província de Matto Grosso" e para muitas pessoas que possivelmente já não acreditavam nos meios suasórios para trazer os índios à civilização, não há em nenhum relatório de presidente de província menção ou ordem alguma para matarem-se os índios quando encontrados. Raramente, noticiava-se que um índio morrera nos curtos embates com as forças. $\mathrm{Na}$ expedição mandada para o alto São Lourenço, os componentes da força tiveram sob cerco os "terríveis", "indomáveis",

${ }^{81}$ Apud: RPP. Maracaju 1881, pp.6e 7. 
"sanguinários", que "atrasa[vam] a indústria", cometiam verdadeiros atos de "barbaridades", horrores que eram publicados nos jornais e que corriam nas conversas. No entanto, segundo a maneira como registraram, os expedicionários seguiram as ordens do comandante imbuído do espírito "civilizatório" e não teriam extravasado as suas, muito prováveis, indignações e crueldades. Não teria sido difícil agir assim, pois não só o sequestro de alguns indígenas na própria aldeia dos coroados demonstra a superioridade bélica, mas a própria posição estratégica e vantajosa de cerco demonstra isso. Não é possível saber se morreram vários indígenas do alto São Lourenço nessa abordagem, forçando muitos a fugir, além dos bororos que os acompanhavam terem sido ofendidos por flechas já praticamente dentro da aldeia dos coroados. Contudo, pode-se perceber que os relatórios queriam e deveriam passar a ideia de que a civilização era mais forte que a barbárie; e isso estava sendo seguido na província. Portanto, não apareciam nos relatórios atos de mortandade deliberada pelos brancos, o que era difícil de não ter acontecido. Ora, as práticas governamentais tinham como justificativa e objetivo a "ação civilizatória" e a "catequização" dos silvícolas, ao mesmo tempo que tomavam suas terras e procuravam submetê-los a outro "mundo do trabalho". Desse modo, atitudes bárbaras, condenadas pelo próprio imperador, tais como matanças de indígenas, seriam a antítese das diretrizes de governos da época, logo, não poderiam constar nos relatórios.

Os 17 índios aprisionados pelo alferes Duarte foram levados para Cuiabá. O presidente, então, formulou uma estratégia que consistia em bons tratamentos aos indígenas capturados para, em seguida, mandá-los de volta às suas antigas aldeias, sendo escoltados somente até uma parte do caminho. Assim, esperava-se que "voltariam com toda a sua gente". Dessa forma, presumia "chamar à civilização a numerosa e temida tribo dos coroados, e tornar úteis à lavoura tantos braços que jazem desaproveitados e que só Ihe têm sido nocivos", o que compensaria " a falta de emigração para esta província." 22

No ano seguinte, chegou-se a considerar, por pouco tempo, que as medidas anteriores teriam surtido efeito e, assim, os confrontos teriam cessado. As "fortes expedições armadas" teriam feito os selvagens "internarem-se pelos sertões" ${ }^{3}$, mas logo registravam que os coroados voltaram às suas correrias. Outro fator que sinalizava o malogro das iniciativas anteriores era o fato dos indígenas, que tinham vivido entre os cuiabanos e mandados como iscas étnicas para atraírem os coroados, não terem retornado para a cidade com "sua gente". Para piorar a situação, o ministério do Império havia comunicado que não era mais possível continuar com despesas avultadas contra os

\footnotetext{
82 APMT.RPP. Barão de Maracaju, 1881, p. 27.

83 APMT. RPP. José Maria de Alencastro. 1882, p. 11.
} 
indígenas. As forças que estavam "pelo sertão", então, receberam ordens para voltar, para contenção de gastos, pois já haviam excedido o crédito feito na administração de Maracaju 84 .

Melancolicamente, o presidente afirmava que as únicas providências passíveis de serem tomadas eram enviar forças no "encalço dos índios" depois de seus ataques, fazer rondas onde os índios teriam sido vistos e distribuir armamentos para os habitantes de áreas sujeitas às agressões ${ }^{85}$, ou seja, nos dizeres do Barão de Batovy, onde pessoas viviam "fora dos centros de povoação". 86

A maior parte dos índios conhecidos e contabilizados em Mato Grosso não era considerada "hostil" pelos governantes. E, quanto aos guerreiros, nesse início da década de 1880, as autoridades já conheciam, pela experiência e esquadrinhamento estatístico dos indígenas, o período de seus ataques, assim como as principais rotas por onde atuavam ${ }^{87}$. $\mathrm{Na}$ verdade, os dirigentes em todo o império do Brasil, desde pelo menos o ano de 1845, procuravam organizar informações sobre os silvícolas. Em Mato Grosso, não foi diferente, quando, desde a década de 1840, procuraram também mapear, calcular seu número e classificar as "famílias" indígenas por sua localização e suposta "índole”. Quanto mais "perto de nossas povoações" fossem suas habitações "fixas", mais "amigáveis" seriam; facilitando, portanto, o uso dessa mão-de-obra em chácaras, fazendas e na cidade, assim como algum comércio com eles (ver SILVA, 2019). De toda forma, nessas classificações, os coroados eram os verdadeiros inimigos e em "estado primitivo", tanto na década de $1840^{88}$ quanto na época de novo mapa da população indígena, na década de $1880^{89}$.

Procurava-se o trabalho estatístico para melhor conhecer o que deveria ser dominado e incluído entre as etnias vistas como subjugadas ou as que assim deveriam ser futuramente. Sobretudo, marcava-se a expansão de uma fronteira, na qual procurava-se definir até onde teria sido estabelecida a hegemonia étnica e cultural dos não-indígenas e não-quilombolas. Hegemonia pretendida pelos que perseguiam certo padrão europeu na construção de um novo Estado nacional nas Américas, cuja população continental era

\footnotetext{
${ }^{84}$ Ver APMT. RPP. José Maria de Alencastro. 1882, pp. 11 a 13 e RPP. José Maria de Alencastro. 1883, pp. $12-15$

${ }^{85}$ APMT. RPP. José Maria de Alencastro. 1882, p. 13.

${ }^{86} \mathrm{E}$ não necessariamente nas cidades, vilas e povoações. RPP. Barão de Batovy. 1884, p. 7

${ }^{87}$ Fato que não as impedia de serem surpreendidos pelos índios. Por isso passou-se a distribuir armas para alguns moradores de certas áreas rurais, o que era proibido e negado até os anos oitenta. Por isso também foram posicionados destacamentos em lugares por onde os índios provavelmente passariam, como o caminho para Cáceres. Mas isto nem sempre impediu que várias pessoas morressem, inclusive soldados, nesse caminho. Por outro lado, também alguns moradores de chácaras conseguiram repelir ataques indígenas, pois esperavam por eles.

88 APMT. RPP. Joaquim José de Oliveira. 1849, p. 403.

89 APMT. Diretoria Geral dos Índios em Cuyabá., diretor geral dos índios Thomas Antônio de Miranda Rodrigues, pp. 2 e 3, anexo ao RPP. Barão de Maracaju, 1880.
} 
marcadamente multiétnica ${ }^{90}$, com variadíssimas culturas e grupos humanos, mas que seria alvo de um processo homogeneizador (Ribeiro, 2000, p. 13).

Um passo exitoso para esse fim foi uma excursão organizada pelo presidente Galdino Pimentel, com o objetivo de ir ao encontro novamente dos coroados. Essa expedição não poderia fugir dos preceitos da Corte, "uma vez que ao nosso estado de civilização", dizia o presidente, "repugna que se empregue contra eles a força pública para exterminá-los." 91 A expedição foi comandada, mais uma vez, pelo alferes Antônio José Duarte e tinha como objetivo trazer índios para Cuiabá. Além de presentes (tais como ferramentas e roupas), também participavam sete indígenas. Esses (seis índias e um índio) eram coroados que "há tempos tinham sido aprisionados e viviam entre" os "brancos" e, assim, já eram percebidos como "afeit[os] aos costumes da vida civilizada"92. À diferença dos planos de Maracaju, em 1881, quando foram enviados indígenas, antes sequestrados, para seus antigos lugares objetivando chamar o restante dos seus, nesta, de 1886, a expedição iria até as "malocas" junto com os indígenas reféns, além de levarem presentes. $\mathrm{Na}$ volta, a expedição conseguiu trazer 28 coroados que seguiram "espontaneamente" e, desde esse momento, ficaram alojados na capital, onde, pelo menos, segundo as ordens do presidente Galdino Pimentel, deveriam ser bem tratados e presenteados, além de catequizados $^{93}$. Entretanto, sem verba especificada para esse fim, a administração acabou por recorrer "ao patriotismo dos mato-grossenses". Nesse sentido, foi formada uma comissão de "pessoas ilustres", que seriam as responsáveis para "angariar os donativos" para os indígenas em Cuiabá ${ }^{94}$

A tática prevista era fazer com que os coroados "acolhidos" pudessem transmitir a notícia aos demais, em outra excursão, e, dessa maneira, estabelecer "relações, trato e amizade com toda a tribo". ${ }^{95}$ Ou seja, seriam iscas étnicas, pois o ideal era atraí-los para que fossem retirados de seu modo de vida e transportá-los para outros lugares circunscritos e delimitados por autoridades provinciais.

Com essa perspectiva, partiu novamente uma expedição, em 1887, comandada pelo mesmo alferes, Antônio José Duarte, levando os indígenas que estiveram alojados em Cuiabá. Essa missão voltou quatro meses depois acompanhada por mais coroados ainda. Possivelmente, muitos estavam cansados de guerra e gostaram do que ouviram de seus

\footnotetext{
90 Ver Pamplona e Doyle (2008).

91 APMT. RPP. Joaquim Galdino Pimentel, 1886, p. 14.

${ }_{92}$ Possivelmente, fora a expedição do capitão Bueno que aprisionara esses coroados. Considerada "bandeira" por travar luta contra os índios, essa expedição chegou à capital com os silvícolas em seu encalço. Mas conseguiram trazer algumas crianças.

${ }^{93}$ APMT.RPP. Joaquim Galdino Pimentel, 1886, p. 15.

94 Ibidem.

95 Ibidem.
} 
conterrâneos. O fato era que o êxito dessa expedição conseguira ser ainda maior que o da primeira, "pois vieram 398 indios, que expontaneamente a acompanharam" até a capital. Em seguida, saíram também de suas aldeias, aproximadamente, mais 200 para se juntarem aos demais ${ }^{96}$.

Prontamente, foram criadas duas colônias, uma no rio das Pratas, afluente do São Lourenço, e outra nas proximidades do rio Piquiri, lugares demarcados onde os coroados deveriam então viver circunscritos. Para essas colônias, foram nomeados dois diretores, entre eles, o alferes Antônio José Duarte. Os diretores das colônias "comandavam fortes destacamentos nelas estabelecidas para evitar a dispersão dos índios e os irem pouco a pouco fazendo habituar ao trabalho e civilização". Dessa forma, foram entregues brindes mais específicos aos novos "colonos": ferramentas para aprenderem o ofício de carpintaria e, sobretudo, materiais para o trabalho agrícola; "que façam grandes plantações, não somente para habituar os índios ao trabalho, como para diminuir a despesa com a sua manutenção", dizia o principal administrador da província. ${ }^{97}$ Essa condição, concentrados em um campo de trabalho, vigiados por homens armados, contrastava drasticamente tanto com os "bons tratamentos" dados na cidade aos indígenas em seu processo de transformação em "iscas" quanto com a forma a que estavam habituados a viver em suas próprias terras, em sua antiga e necessária "rede de vida".

O resultado desse procedimento estimulou o presidente de província e os dirigentes locais a procurarem fazer o mesmo com duas outras "tribos", os cabixis e os mãibaris, que ainda disputavam aguerridamente o território com os habitantes do vale do Guaporé, ao norte da província. Desse modo, foi dada a ordem para a apreensão de alguns membros dessas "tribos", que ainda hostilizavam francamente os que estavam na empreitada de tomar-lhes as terras em nome do império. ${ }^{98}$

Trazer o indígena à civilização que os dirigentes queriam construir em Mato Grosso não apenas livraria o agricultor das agressões dos silvícolas, como livraria os viajantes de serem assaltados e mortos. Ao "catequizar" o indígena e retirá-lo de seu habitat original, destituindo-o de todas as suas formas de organização socioeconômica e cultural procurando modificar toda a vida, da economia à religião e às formas de contato e vivência com a natureza e com o mundo -, os dirigentes tentavam transformar o "perigoso silvícola" em operosa mão-de-obra para a agricultura e comércio mato-grossense, ajudando a "povoar" o grande território, explorando seus recursos à maneira dos brancos, contribuindo,

\footnotetext{
96 APMT. RVPP. José Joaquim Ramos Ferreira. 1887,pp. 86-87.

97 Ibidem, p.87.

98 Ibidem.
} 
assim, para anexar o Mato Grosso às regiões modelos de civilização, ao mesmo tempo que instituía uma hegemonia étnica nas áreas fronteiriças do país:

"Creio que já é tempo de ensaiarmos a colonização indígena, já que poucas esperanças devemos nutrir de colonizar com a imigração estrangeira os nossos desertos tão abundantes de riquezas naturais. Conheço quanto custa arrancar essas hordas da barbárie em que vivem, mas mesmo assim, não se me afigura a empresa tão difícil, que não se deva tentar, atentos os grandes benefícios que dela se espera." 99

Se, no momento em que parecia se esvair a escravidão, dirigentes e latifundiários do Sudeste/Sul preferiam o homem vindo do exterior para continuar ampliando suas plantações, em Mato Grosso, o braço indígena seria uma possibilidade para a ocupação produtiva da província tida como deserta. Contudo, dois problemas oriundos da própria consideração de "civilização" se apresentavam para os silvícolas serem incorporados como trabalhadores no país que se queria constituir. O primeiro era embasado na própria experiência dos presidentes de província, ou seja, de quem vinha dos lugares onde a civilização se avantajava, como eram pensadas algumas cidades do litoral do Império e do atual Sudeste. Como já dizia um presidente antes do estabelecimento dessas colônias:

"[Se em relação às populações] que já tem alguma cultura intelectual o antagonismo nos costumes, nas crenças, nos prejuízos e até nos vícios, gera prevenções hostis contra os que pretendem civilizá-los, - o que não sucederá com os selvagens em completa ignorância?"100

Outro problema decorrente desse era o fato de que, mesmo sendo constantemente vigiados nas colônias, nem todos os indígenas permaneciam nelas. Pelo contrário. Embora, nos anos seguintes, ocorressem alguns ingressos de indígenas nas colônias, a saída foi

\footnotetext{
${ }_{99}$ APMT. RVPP. José Joaquim Ramos Ferreira, 1887, p.89.

100 APMT.RPP. Joaquim José Pedrosa, 1879, p. 81. No penúltimo ano do império, 1888, o presidente Francisco Raphael de Melo Rego também já se demonstrava céptico no aproveitamento dos índios das colônias como "roteadores" das imensas terras que a província possuía. Os adultos não se habituavam a um trabalho regular que procuravam impor-lhes e era difícil largarem da vida "promíscua" que levavam na selva. Pareciam tão somente interessados nas "prendas e nas bebidas que conseguiam com pessoas não idôneas". Também reclamava da falta de catequizadores, pois, nas colônias, que pareciam mais um "grande aldeamento", os índios somente "aprendiam" coisas com os guardas lá estabelecidos. Esses guardas, na opinião do presidente, estavam longe de ser algum exemplo para os índios. RPP. Francisco Raphael de Mello Rego, 1888, pp. 16-18. Enfim, os aspectos "morais" colocariam por terra os planejamentos da "assimilação" ou, de certa forma, os encaminhariam para o tipo de "assimilado" esperado ou desejado, semelhante aos soldados rasos que defendiam as armas do país?
} 
maior, tendendo a uma certa estabilidade no último ano do Império. De toda forma, era difícil que os indígenas suprissem tão rápida e satisfatoriamente a falta de mão-de-obra, apontada frequentemente na província, que transformassem o Oeste do Brasil num imenso campo cultivado, acompanhado de "cidades populosas", como desejavam seus dirigentes.

De toda maneira, o que esses dirigentes decerto puderam comemorar na década de 1880, depois de muitos e prolongados embates, foi o fato de os coroados, arrebentados na espinha dorsal, nunca mais terem sido os mesmos. Não se registrava mais o envio de expedições para "exterminar semelhantes feras", como na década de 1840. Chegava-se ao final do Império com campo aberto para tomarem as áreas que antes forneciam a vida aos coroados, ao mesmo tempo que podiam dispor de sua mão-de-obra e produtos, agora, voltados para a sociedade envolvente.

\section{Bibliografia:}

ALMEIDA, Maria Regina Celestino de. Os índios no tempo da corte: reflexões sobre política indigenista e cultura política indígena no Rio de Janeiro oitocentista . Revista USP, [S. I.], n. 79, p. 94-105, 2008. DOI: 10.11606/issn.2316-9036.v0i79p94-105. Disponível em: https://www.revistas.usp.br/revusp/article/view/13697. Acesso em: 11 jan. 2021.

ALMEIDA. Maria Regina Celestino de. Os índios na História do Brasil. Rio de Janeiro: Fundação Getúlio Vargas, 2017.

AMADO, Janaína; ANZAI, Leny Caselli (org). Anais de Vila Bela. Cuiabá: EdUFMT, 2006.

CUNHA, Manuela Carneiro da. Política indigenista no século XIX. In. História dos índios no Brasil. São Paulo: Companhia das Letras, 1992. p. 133-154.

HAREY, David. Notes towards a theory of uneven geographical development. In: Harvey, D (ed.) Spaces of Global Capitalism: A Theory of Uneven Geographical Development. London: Verso, 2009, pp. 69-116.

MALLON, Florencia E. Indigenous People and Nation-States in Spanish America, 17802000. In: Moya, José C. (ed)The Oxford Handbook of Latin American History. Oxford: Oxford University Press, 2011

MOREIRA DA COSTA, José Eduardo Fernandes. "Ikuiapá e os fluxos cósmicos: processos de desterritorialização do espaço Boe-Bororo". In: Revista do Instituto Histórico e Geográfico de Mato Grosso. Cuiabá, Número 81, 2019. Pp.83-118.

MOREIRA DA COSTA, José Eduardo Fernandes. A Coroa do mundo: religião, território e territorialidade Chiquitano. Ed. UFMT, 2006. 
NAVARRETE LINARES, Federico. Hacia otra historia de América, : nuevas miradas sobre el cambio cultural y las relaciones interétnicas. México: Universidad Nacional Autónoma de México (Instituto de Investigaciones Históricas), 2015.

NAVARRETE LINARES, Federico. Los puebLos indígenas de iberoamérica ante La crisis de 1808. Revista de História. N. 159, 2008. São Paulo.

PAMPLONA, Marco A. DOYLE, Don H. Nação e nacionalismo no novo mundo - A formação de Estados-nação no século XIX. Rio de Janeiro/ São Paulo: 2008.

RIBEIRO, Darcy. O processo civilizador. São Paulo: Companhia das Letras, 2000 [1968].

RODRIGUES, Bruno Pinheiro. Homens de ferro, mulheres de pedra- O itinerário de resistência de africanos escravizados entre a África Centro-Ocidental e a América espanhola. Fugas, formação de quilombos e conspirações urbanas (1720-1809). Curitiba: Appris, 2019.

SAMPAIO, Patrícia Melo. Política indigenista no Brasil Imperial. In: GRINBERG, Keila; SALLES, Ricardo. O Brasil imperial. Rio de Janeiro: Civilização Brasileira, 2009. Vol. I. (1808-1831). p.175-206.

SENA, Ernesto Cerveira de. Entre anarquizadores e pessoas de costumes - a dinâmica política nas fronteiras do Império - Mato Grosso (1834-1870). Cuiabá: Carlini \& Caniato/EdUFMT, 2009.

SILVA, Verone C. da. "A face indígena de Cuiabá". In: SENA, E.C.; SIQUIERA, Elizabet M. 300 anos de Cuiabá - Múltiplos olhares. Cuiabá: Carlini \& Caniato, 2019.

VASCONCELOS, Cláudio Alves de. A Questão Indígena na Província de Mato Grosso: Conflito, Trama e Continuidade. São Paulo: USP/FFLCH, tese de doutorado, 1995.

VOLPATO, Luiza Rios Ricci. A Conquista da Terra no Universo Da Pobreza. São Paulo: Hucitec, 1987. 


\section{Capítulo 05 \\ OCULTAÇÃO E PARTICIPAÇÃO INDÍGENA NO CONFLITO DO \\ CHACO}

\section{ANDRÉ HENRIQUE ELTZ}

\section{A Bolívia da independência ao início da guerra: uma breve contextualização}

A Bolívia e seu instigante passado histórico de conflitos fronteiriços são marcados por perdas territoriais que constituem "veias abertas" no corpo social boliviano. Um país que no seu passado colonial seria explorado duramente pelos espanhóis e, mesmo após sua independência, continuaria a sofrer um processo de interferências de potências europeias e americanas.

Tornando-se oficialmente independente da Espanha em 1825, o processo revolucionário que culminou com a independência e a criação do Estado-nação boliviano aproxima-se com o ocorrido na Nova Espanha, segundo Eric Van Young e José Carlos Chiaramonte.Young propõe que não houve uma consciência nacional no sentido de luta contra o domínio espanhol durante o processo de independência do México, nem sentimentos nacionalistas em grande escala ao longo do século XIX. Segundo afirma Young, as revoluções que preparam caminhos para as novas nações tendem a ser acontecimentos complexos, em que grupos diferentes do povo se engajam em violência política coletiva por diferentes motivos, não sendo a criação da nação, necessariamente, o principal deles. Assim como pontuou Young, Chiaramonte discute a formação dos Estados nacionais na América lbérica no sentido da inexistência de uma consciência nacional antes e durante os processos de independência. Chiaramonte critica os historiadores defensores da visão de que as atuais nações da América Ibérica já existiam quando iniciam os ciclos de independência. O autor critica a ideia da existência, já no final da colônia, de comunidades que lutavam pela independência a partir de uma identidade coletiva, ou seja, por querer formar Estados independentes em virtude de possuir uma cultura comum, formando, assim, um protonacionalismo. Para Chiaramonte, existiam sujeitos políticos coletivos ao nível das cidades ou províncias, os chamados "pueblos". Contudo, isso não ocorria no sentido de se ter um sentimento de identidade nacional, pois, no início dos processos de independência, os "pueblos" possuíam conceitos básicos de ciência política, baseados no direito natural e de gentes. Esses sujeitos pensavam o coletivo em um âmbito menor. Portanto, sua hipótese está baseada no fato de que os processos de independência 
aconteceram das mais diversas formas nos diversos locais, sem uma forma homogênea, sem um pensamento comum e sem ter um sentido de pertencimento pelo nacional.

Passados os anos da independência, a Bolívia entrava no período republicano com a herança do período colonial. A nova república estava a cargo dos latifundiários, aliados às decadentes empresas mineiras, grupos que não se somaram à causa da independência para transformar a velha sociedade, pelo contrário, queriam manter a antiga estrutura. A maior parte da nação pertencia a esse sistema agrário de grandes propriedades, as haciendas, servindo como força de trabalho e prestando serviços pessoais aos patrões, em condições de exploração, a pongueaje. Fazendeiros, proprietários de minas, industriais, comerciantes, todos formavam uma oligarquia estável e com respeitável poder político, dirigiam a vida econômica e política da nação. De acordo com Rafael Calvo Puente, "é um setor oligárquico e racista, de mentalidade colonial, parasitário do Estado, e desinteressado de tudo que possa levar ao desenvolvimento nacional". Ainda, a maioria indígena seguia submetida aos caprichos dessa oligarquia que não consegue desenvolver o país e depende, nos primeiros anos, exclusivamente dos tributos indígenas para a manutenção do Estado.

Os problemas de fronteira territorial envolvendo a Bolívia fazem parte da história do país, a exemplo, a guerra do pacífico 1879-1883- conflito com o Chile no qual a Bolívia perdeu a região do litoral que Ihe possibilitava acesso ao oceano pacífico. Vale ressaltar, ainda, a disputa fronteiriça com o Brasil em 1903, em relação ao Acre. Não bastassem esses dois conflitos, os anos 1930 trariam mais um embate territorial, dessa vez, com o vizinho Paraguai. Conflito que marcaria a história boliviana como o maior conflito bélico até então, "A Guerra do Chaco".

O conflito ocorreu entre os anos de 1932 e 1935. Como as fronteiras da região não foram muito bem definidas pelo colonialismo espanhol e durante o processo de independência do que viria a ser a Bolívia e o Paraguai, cada um queria a maior parte da região do Chaco para si. O conflito deixou um saldo de aproximadamente 60 mil bolivianos e 30 mil paraguaios mortos, tendo resultado na derrota dos bolivianos, a perda e anexação de parte de seu território pelos paraguaios.

Há algumas interpretações clássicas sobre os motivos da guerra, entre as mais importantes, segundo Carlos Mesa, estão as teorias de uma guerra pelo suposto petróleo da região e da busca da Bolívia por uma ligação fluvial e marítima com o resto do mundo.

Além dessas duas teses explicativas para as causas da guerra, a outra questão que norteia o conflito refere-se às disputas territoriais de longa data entre os dois países beligerantes. Com a formação das duas repúblicas, os limites territoriais não foram muito 
bem definidos, várias tentativas de encontrar uma solução para a questão foram desenvolvidas ao longo do século XIX. Tratados foram discutidos entre os dois Estados sempre sem sucesso, ora a Bolívia não aceitava as condições, ora o Paraguai. Segundo Gabriela Caballero Dalla-Corte, na visão internacional, a importância do espaço disputado se dava mais em função das expectativas geradas em torno dos recursos potenciais existentes. A guerra foi, portanto, uma luta pela soberania de territórios e por delimitação de fronteiras nacionais. Foi uma guerra defensiva na qual o inimigo foi sendo forjado com constantes denúncias de invasão do território nacional reforçando os ideais de soberania nacional.

Para Carlos Mesa, os limites internacionais da Bolívia estavam baseados nos títulos coloniais herdados pela república e reconhecidos internacionalmente. O governo boliviano apresentava suas pretensões baseadas em documentos da época colonial, considerando que suas fronteiras incluíam todas as terras da antiga Audiência de Charcas.

No mesmo sentido, para o Paraguai, a principal tese defendida quanto às causas do conflito diz respeito às questões territoriais. Apresentando, também, documentação colonial, esse país afirmava que o Chaco era região territorial pertencente à Assunção. $A$ historiografia paraguaia pesquisada afirma que o Chaco é região do Paraguai desde os primeiros anos da colônia espanhola. Ramón César Bejarano, em seus estudos sobre as expedições que transitaram pelo Chaco ao longo dos séculos após a chegada dos espanhóis à América, defende que o lugar é posse paraguaia.

A disputa territorial, em nosso entendimento, parece ser a tese mais convincente para as causas do conflito. As delimitações territoriais, segundo Marcelo Lopes Souza, são um fator importante para os modernos Estados-nação, pois, em sua formação no século XIX, a fronteira geopolítica era essencial, fazia parte do discurso de legitimação das elites responsáveis pela formação da nação. A formação do Estado-nação boliviano foi construída nos moldes citados por Souza, a partir da importância das delimitações territoriais no início do processo e, posteriormente, sua manutenção. As ações dos governantes bolivianos ao longo dos anos pós independência procuravam defender as áreas mais distantes das grandes cidades, mesmo considerando como áreas "desertas", "sem habitantes", e procuravam incorporar ao nacional os habitantes desses espaços que se sentiam pertencentes à nação ou não. As preocupações com a "conquista" dos espaços fronteiriços faziam parte das intenções das políticas nacionais, porém, enquanto tal processo não era colocado efetivamente em prática, deixava o território fronteiriço vulnerável à ocupação do país vizinho. 
No entanto, o território é muito mais que simples delimitações lineares de espaços geográficos. O território é um espaço onde grupos exercem relações sociais complexas e é constantemente transformado por essas relações. Assim, o espaço perpassado pelas relações de poder é o espaço vivido pelas experiências individuais e coletivas, ou seja, tem, sobretudo, um caráter humano. Segundo Marcel Roncayolo, a identidade dos grupos provém mais da cultura, ou seja, da produção do espaço através das relações sociais, do que do espaço físico propriamente dito. Pensando, então, no Estado com grande poder de territorializar espaços, para Roncayolo, em lugares onde o povoamento é mais contínuo, a tendência é que o Estado exerça um domínio mais forte, a fronteira tende para uma "linha ideal". Porém, nos limites territoriais estabelecidos entre Estados, onde supostamente o domínio é mais fraco, não se apaga a multiplicidade das relações entre os dois lados. Conforme Ernesto Cerveira de Sena, a "produção de espaço não gera necessariamente uma fronteira linear entre Estados, pois participam também dessa política de tomar áreas geográficas para si povos sem Estado, ou com vínculos frouxos com este [...]". Sena, destacando a grande influência das discussões de Claude Raffestin sobre "territorialização" e "fronteira", aponta para o fato de que a fronteira não é apenas espacial, ela também é temporal. Em sua análise sobre as fronteiras entre o Brasil e Bolívia, observa que ambos os países recorreram ao passado colonial procurando um suposto fundamento superior que comprovasse um acordo entre as antigas metrópoles, que, na verdade, nunca foi consolidado.

A mesma análise pode ser utilizada para o caso das fronteiras entre as repúblicas da Bolívia e do Paraguai. Uma vez que as fronteiras não são apenas espaciais, mas também temporais, ou seja, a fronteira é datada, entendemos que as documentações que os dois países utilizavam para defesa de seus territórios não serviam de garantia alguma.

É fato que as discussões sobre as fronteiras nos anos anteriores a 1932 não evitaram o confronto entre os dois exércitos nacionais. Desse modo, conforme Nicolas Richard, entendemos que a chegada dos militares no Chaco se traduziu na ocupação e no controle direto dessa região por parte dos Estados, provocando profundas alterações nas sociedades que habitavam o local. Instalou-se, na região, uma complexa rede de relações a partir do contato com um elemento externo, levando os diferentes povos indígenas a estabelecer estratégias de resistência e interação, redefinindo seus espaços e suas identidades.

Dessa maneira, pensando o território através das relações de poder, para o estudo do conflito em questão, faremos uso dos conceitos de mestiçagem e etnogênese. Esses conceitos estão diretamente relacionados à fronteira política e aos espaços vividos por 
povos que mantêm "vínculos frouxos" com os Estados. Ainda, esses dois conceitos são determinantes para o entendimento da produção de espaço por povos fronteiriços, já que esses espaços estão constantemente se modificando em função de contatos entre diferentes povos da mesma região e em função do contato com elementos externos.

Nesse sentido, inicialmente, demonstraremos que alguns autores, bolivianos e de outros países, que são referências na escrita de história da Bolívia e de história da guerra, em suas narrativas, consideram o Chaco um "deserto" e ocultam a participação indígena nas disputas pela área chaquenha. Em contraponto ao apagamento nas narrativas de parte da historiografia, demonstraremos um pouco da história indígena na guerra através de construções históricas que dão visibilidade aos indígenas, atribuindo-lhes protagonismo histórico. A historiografia que utilizamos é produzida por historiadores e antropólogos que trabalham com etno-história enfatizando as dinâmicas de diferentes grupos que habitam regiões fronteiriças, dentre eles, Guillaume Boccara, Isabelle Combès e Jürgen Riester. Para demonstrar exemplos de visibilidade indígena, analisaremos brevemente a dinâmica de um grupo indígena conhecido como Nivaclé - especificamente, a história de um personagem desse grupo, o sargento Tarija -, bem como grupos Isoseños que habitavam a região oeste do Chaco, profundamente afetada pela guerra.

\section{A história da guerra e o apagamento dos indígenas}

Alguns livros de História da Bolívia são referências nesse país por fazerem construções históricas que privilegiam os grandes heróis nacionais, os grandes fatos históricos, ou seja, se preocupam com assuntos de ordem política e social. Nesse sentido, essas obras aproximam-se da história narrativa tradicional dos historiadores positivistas. Nessas construções históricas, os indígenas aparecem, geralmente, como seres passivos. Enfatizamos que esses livros de História da Bolívia são construções sobre história geral do país produzidas para atingir o grande público. Uma obra que é referência na Bolívia chamase "Historia de Bolivia". Existem, ainda, outras produções que são de história específica da guerra do Chaco que também seguem as mesmas características.

A história escrita por esses autores apresenta o território chaquenho como um lugar despovoado, deserto, vazio, de um meio ambiente hostil e de uma natureza selvagem e perigosa.

Carlos Mesa apresenta o Chaco como sendo uma região com aproximadamente 290 $000 \mathrm{~km}^{2}$ a uma altitude de $225 \mathrm{~m}$ sobre o nível do mar. A região é formada por grandes extensões planas cobertas de vegetação herbácea e espinhosa, com solo muito arenoso e 
seco. O autor afirma, ainda, que, nos anos do conflito, o Chaco "contaba con una población total de no más de 70000 almas [...]".

Por ser uma região onde a presença do Estado era praticamente inexistente, considerar o Chaco como um lugar despovoado fazia parte do discurso de mobilização do Estado em relação ao conflito. Segundo Luc Capdevila, na descrição do Chaco como um "deserto", foi disseminada a ideia de ocupar, colonizar e civilizar. Essas três ações estão articuladas com a ideia de que as terras chaquenhas são um pedaço do território nacional. Além disso, a ideia de "deserto" estava ligada ao interesse pelos territórios por colonizar; logo, não significava, exatamente, que estavam vazios, apenas não estavam habitados pelo Estado, estavam habitados por indígenas.

Além de descrever o Chaco dessa maneira, percebe-se que a historiografia pesquisada utiliza poucas linhas para descrever quem são os habitantes do Chaco e os militares que combateram diretamente nas linhas de frente; principalmente, em relação aos soldados, já que, tratando-se dos oficiais, a identificação é mais fácil de ser percebida. A seguir, podemos observar as poucas referências aos indígenas de um autor que escreve sobre o conflito.

O Tenente da reserva do exército boliviano Juan Granier Chirveches escreveu sua vivência no conflito em um diário que foi publicado por sua filha em forma de livro, em 2004. Granier ingressou no conflito como voluntário, no dia 9 de outubro de 1932, já que era oficial da reserva e sua classe não havia sido chamada para a guerra. No livro, podemos ter acesso a seus relatos dia a dia desde a sua incorporação até o dia 16 de setembro de 1935, quando, ao fim do conflito, é dada sua baixa das fileiras do exército. Durante os três anos em que esteve na guerra, podemos ver, através do seu ponto de vista, a maneira pela qual a Bolívia atuou no conflito. O autor faz uma narrativa de todos os seus deslocamentos pela região do Chaco, pelos fortes que passou, pelas cidades onde esteve. Narra, ainda, as principais batalhas e os bastidores do conflito. Ele faz poucas referências sobre a composição étnica dos grupos locais.

Em 9 de dezembro de 1932, ele descreve um pouco do forte Platanillos: "es un fortín boliviano que fundó el Cap. Víctor Ustarez, descubridor del lugar en el año 1931, donde encontré varias sendas. Algunos indicios de las muchas tolderías [...]".Podemos notar, em sua descrição, que é enfatizado o referido Capitão como fosse realmente o descobridor do lugar. De acordo com um mapa étnico do Chaco, Boreal, o lugar onde foi instalado o forte Platanillos era área do grupo Chulupi (Nivaclé). Quando Granier fala de tolderías, há uma referência explicando que o termo significa "casas eventuais de indígenas nômades do lugar". Podemos observar que Granier faz referência aos moradores locais. 
No dia primeiro de novembro de 1933, Granier conta que saiu do forte Saavedra às 8h da manhã em uma patrulha nas redondezas. Outras patrulhas também haviam saído em outras direções. Granier relata que recebeu a informação de que uma patrulha de quatro homens havia se infiltrado por trilhas e que haviam tido contato com os indígenas locais. Ao retornar à Saavedra, Granier relata: "Al regreso, sólo encontré en el trayecto un campamento de indios de la tribu de los Chulupis, raza miserable y sucia".

Novamente, em seu diário, no dia 18 de outubro de 1934, há um relato de contato com indígenas Chulupis, em companhia do Major Santa Cruz em uma movimentação pela região do forte Ballivián: "Visitamos una tribu de indios Chulupis, donde tomé unas fotografías en que Santa Cruz rodeado de indios cuya vestimenta es la desnudez, pues viven en estado salvaje".

Apenas essas três referências aos habitantes do Chaco podem ser observadas ao longo da obra. No decorrer dos dois anos e meio em que atuou na campanha do Chaco, Granier narrou acontecimentos que envolviam os bastidores da política nacional, principalmente, a relação entre os comandantes do exército e o Presidente boliviano Daniel Salamanca. Sua narrativa está fundada em um quadro histórico que prioriza os feitos diplomáticos, políticos e militares em detrimento da figura indígena.

Outro autor que escreve sobre a guerra, Roberto Querejazu Calvo, foi também militar do exército boliviano. O soldado de primeira linha narra a história da guerra do Chaco a partir das batalhas; pode ser observada em detalhes toda a movimentação dos exércitos pelo território em disputa. Querejazu ingressou na guerra, ao que nos parece, como recruta da classe de 1932. Na apresentação do livro feita pelos editores, é salientado que a obra foi escrita por um soldado. Os editores afirmam que é um grande livro escrito com o próprio sangue de seu autor. Porém, em quase duzentas páginas da obra, em nenhum momento, é possível identificar quem são os habitantes do Chaco ou quem são os soldados bolivianos que combateram na região; nem a história do próprio autor é tratada no livro.

Observamos que Carlos Mesa, Juan Granier Chirveches e Roberto Querejazu Calvo fazem pouca referência aos indígenas em seus textos. Não é possível extrair informações mais completas ou mais específicas de quem realmente eram esses soldados e quem eram os povos indígenas do Chaco. No caso de Granier e Querejazu, sendo militares que combateram nas frentes do Chaco, ocultar dos registros ou apenas citar em poucas palavras a presença dos povos indígenas chaquenhos nos parece algo bem subjetivo. A leitura dos apontamentos do diário de Granier comprova que ele, enquanto esteve no Chaco, transitou constantemente por áreas com presença de indígenas locais. Portanto, há um ocultamento da figura indígena em suas narrativas. 


\section{Participação dos povos indígenas na guerra}

A guerra alterou profundamente a dinâmica dos povos indígenas da região. Com o início das mobilizações da Bolívia e do Paraguai em direção a esse território distante do centro das duas nações, a estrutura de funcionamento dos povos indígenas da região passou a sofrer com mais intensidade a presença de uma cultura diferente. O Estado, no momento que intensifica sua presença na região, impõe suas práticas culturais levando diversos problemas às populações locais; diante das adversidades, essas populações ficaram em situação passiva e, ao mesmo tempo, ativa, criando estratégias de sobrevivência, modificando seu cotidiano e alterando sua identidade. A chegada dos exércitos e o desenrolar do conflito provocaram mudanças significativas no mapa da região. A guerra trouxe mortes, provocou migrações forçadas, destruição de aldeamentos e profundas trocas culturais, ao ponto de fazer desaparecer antigos costumes e inserir novos.

Pensando a partir das intensas trocas culturais que a guerra proporcionou à região e utilizando os conceitos de mestiçagem e etnogênese, é possível mostrar que os povos indígenas do Chaco não passaram despercebidos diante dos fatos, ao contrário, tiveram importante participação no conflito.

E o que vem a ser a mestiçagem e a etnogênese? Para Guillaume Boccara, a etnogênese, que, primeiramente, correspondia à emergência física de novos grupos políticos através da influência de um grupo externo, tende hoje em dia a caracterizar processos muito diversos de transformações não somente políticas, mas também nas formas identitárias de definição de um mesmo grupo através do tempo. Ao desvincular a noção de etnogênese de sua concepção biológica, é possível enfatizar as capacidades de adaptação e de criação das sociedades indígenas, começando a considerar a possibilidade de que novas configurações sociais se desenharam através da incorporação de elementos alógenos e mediante consecutivas modificações nas definições de si mesmo.

Nessa mesma perspectiva, Silvia Ratto afirma que a mestiçagem não foi só biológica, estendeu-se a todo tipo de contato em que o empréstimo e a mescla de características culturais foram uma parte intrínseca. Isso reflete a necessidade que grupos têm de inventar diariamente modos de coexistência e soluções para sobreviver.

Boccara e Ratto utilizam o conceito de "middle ground" para pensar esse espaço de contato onde não há limites impostos pelo Estado-nação. O espaço de contato é entendido tanto como um espaço real quanto simbólico, onde se desenrolam novas formas de comunicação e comportamento. Portanto, nessa concepção, a fronteira é um espaço formado por um complexo processo de intercâmbio cultural, equilíbrio de poder e criação 
de novas formas sociais. Para Ratto, a ideia de sociedade fronteiriça multicultural oferecia uma visão alternativa de encontro, no qual era possível detectar a convivência pacífica e o acomodamento criativo dos sujeitos em contato.

Assim, pensamos o espaço territorial dos povos indígenas do Chaco como um espaço que foi transformado por novas relações de poder que se estabeleceram com os primeiros contatos entre indígenas e a cultura ocidental (Estado, militares), sem esquecer que essa transformação é datada, é temporal.

Dessa maneira, processos de etnogênese e mestiçagem ocorreram com diversas etnias do Chaco. Utilizando bibliografia que escreve a história indígena através de estudos etno-históricos e antropológicos, podemos demonstrar como ocorreu esse processo. As principais bibliografias que representam esses estudos são "MalaGuerra e "Los Hombres Transparentes". Os autores dos diversos artigos que compõem essas duas obras trazem exemplos das profundas alterações sofridas pelos povos com a guerra. Alguns desses autores são membros do programa de investigação "Los indígenas en la guerra de Chaco", financiado pela Agência Nacional de Investigação da França, vinculada à Universidade de Rennes 2, França. Publicadas respectivamente nos anos de 2008 e 2010, as duas obras apresentam os objetivos de: demonstrar que a guerra não aconteceu sobre um deserto, mas sim em uma região habitada por sociedades humanas; e, ainda, repensar a guerra através da história indígena. Conforme as obras citadas, entre as etnias mais afetadas pelo conflito, estão os Chulupis, grupo que se localizava às margens do rio Pilcomayo, uma região onde foram travadas as batalhas mais intensas. Chulupi era o nome desse grupo em 1931, porém, os autores trabalhados utilizam o nome atual, os Nivaclés.

\section{Mestiçagem e etnogênese entre os Nivaclés}

Um grupo que sofreu profundas alterações em seu cotidiano foi o dos Nivaclés. Tradicionalmente, os Nivaclés ocupavam a região do rio Pilcomayo médio, em sua margem direita. Essa região era reivindicada pelos dois países - o Estado boliviano considerava o território Nivaclé dentro de sua fronteira e o Estado paraguaio considerava como pertencente a sua nação. Os momentos de instabilidade entre os grupos Nivaclés ocorreram ainda no período anterior à guerra, com o avanço da colonização de colonos "brancos" no norte argentino e a instalação dos fortes bolivianos na região a partir de 1925. Além dos contatos citados, em 1934, os Nivaclés sofreriam ainda o contato com os militares paraguaios em seu avanço sobre os fortes bolivianos. Entre os diferentes momentos que alteraram a dinâmica dos Nivaclés, a guerra foi o mais intenso período de pressão sobre 
eles. O impacto do conflito provocou um efeito desarticulador na estrutura Nivaclé, reterritorializando seus espaços através das múltiplas variáveis que a guerra trouxe.

Segundo Miguel Fritz, os primeiros conflitos entre os militares bolivianos e indivíduos Nivaclés ocorreram após a instalação dos diversos fortes sobre o espaço indígena. A chegada desses novos elementos na região, a partir do final do século XIX, foi determinante para a modificação das relações internas e externas desse grupo.

A história de um indivíduo Nivaclé que teve sua vida alterada com a chegada dos militares bolivianos e a instalação do forte Esteros na região do rio Pilcomayo médio mostranos um exemplo de mestiçagem e etnogênese. O personagem é o sargento Tarija. A história de Tarija começou quando sua família encontrou com uma patrulha militar boliviana. Em meio ao encontro, desencadeou-se um pequeno conflito no qual seu pai foi morto, seus irmãos conseguiram escapar, ele foi feito prisioneiro e levado para o forte Esteros. Tarija tinha em torno de 10 anos quando ocorreu o incidente. No forte, os militares criaram Tarija, deram-Ihe o que comer, ensinaram a ler e escrever. De acordo com Pablo Barbosa e Nicolás Richard, nessa circunstância, o jovem Tarija foi transformado em soldado desse forte. Os autores não conseguem definir muito bem a data do acontecimento, mas acreditam que foi na época da estruturação de Esteros; portanto, quando inicia a guerra, Tarija devia ter em torno de 30 anos.

O forte Esteros era a última fortificação boliviana às margens do rio Pilcomayo. Segundo Barbosa e Richard, devido à grande distância em relação às cidades bolivianas, o abastecimento do exército era feito pelo norte argentino, logo, por território Nivaclé. Assim, a relação entre os militares e o grupo Nivaclé era constante. Nos anos posteriores à fundação do forte Esteros, a relação entre o dispositivo militar e o espaço indígena era relativamente equilibrada e estável. A partir de 1923, com a intensificação da presença militar, o forte Esteros serviu como base para o avanço boliviano em direção à região central do Chaco. Estando o forte dentro do espaço Nivaclé, as relações entre indígenas e integrantes do corpo militar eram intensas. $O$ trânsito de homens e mulheres Nivaclés ao interior do forte era constante, diário. Segundo Barbosa e Richard, Tarija fazia a mediação desse contato. Tarija levava muitos Nivaclés ao forte boliviano. Também havia a presença de mulheres Nivaclés no forte. Nesse sentido, os autores destacam que a relação entre militares e mulheres se deu assimetricamente, não havia somente passividade por parte das mulheres. Em um depoimento de uma mulher Nivaclé, fica evidente que as mulheres não estavam no forte em situação passiva, pois desenvolveram estratégias em suas relações com os militares: "Las mujeres que se juntaban con los bolivianos [...] trabajaban así como lavanderas, cocineras, y la comida que sobraba después se la llevaban a su gente 
en las aldeas". Existem relatos de que as mulheres serviam também como "prostitutas" para os militares bolivianos; exemplo que remete a casoscomo essesé de uma liderança indígena que atuou em 1980, na Bolívia, Alberto Santa Cruz, filho de uma mulher Nivaclé e do comandante do forte Esteros na época, o oficial boliviano de nome Santa Cruz.

Barbosa e Richard apontam que, em determinado momento, entre idas e vindas às aldeias Nivaclés e a iminência da guerra, Tarija organizava a vingança da morte de seu pai. Transitando entre a identidade de militar boliviano e a identidade Nivaclé, Tarija deixa de ser boliviano e incorpora sua raiz Nivaclé. Em suas visitas aos acampamentos, vestido como militar com seu uniforme, Tarija alertava sobre a iminência da guerra com os paraguaios e aconselhava os indivíduos recrutados a desertar e os integrantes dos grupos a se deslocarem para locais distantes dali, onde nem paraguaios nem bolivianos fossem capazes de encontrá-los. O conselho dado por Tarija surtiu efeito. Os Nivaclés arregimentados desertaram em grande quantidade, levando consigo armas e uniformes recebidos dos militares: "Por consejo de Tarija, los jóvenes conscriptos van abandonando el fortín, llevando consigo las armas y uniformes recibidos de los bolivianos".

\section{A dinâmica de alguns grupos Isoseños diante do conflito}

A região oeste do Chaco também foi profundamente afetada pela guerra. Os povos guarani falantes ocupavam espaços que foram palcos da batalha entre o Paraguai e a Bolívia, sendo, assim, afetados diretamente pelo conflito. Destruição de grande parte de sua cultura, perda de soberania de seus territórios, destruição de aldeias, migrações, genocídio. Assim como os demais grupos indígenas do Chaco, os Isoseños também sofreram as consequências da guerra.

Grupos Isoseños já haviam tido contato com os "brancos" antes da guerra, em constantes disputas de terra. Segundo Jürgen Riester, o Isoso é o local onde vivem os Isoseños, território localizado às margens esquerda e direita do rio Parapetí. Suas aldeias estão localizadas próximas ao rio porque seus cultivos dependem das águas. Combès descreve que, a poucos quilômetros ao sul de Charagua, o rio Parapetí nasce nos vales andinos e corre em direção às planícies chaquenhas. Riester aponta que, ao longo da história, os habitantes da região têm recebido diversos nomes: Tapui, Chiriguano, Isoseño, Guaraní. O autor explica que, devido aos habitantes se auto identificarem como Isoseños, preferem utilizar esse nome para identificá-los.

Riester observa que ocorriam disputas de terra na região entre os karai e os indígenas locais, por volta de 1925. A desconfiança frente aos "brancos" é uma atitude 
generalizada entre os Isoseños antes da guerra, resultado de um longo tempo de relações conturbadas. De acordo com Combès, muitos criadores de gado já haviam instalado fazendas no Isoso desde 1843. Nessa relação, os Isoseños não ficavam em situação passiva diante dos interesses dos "brancos" por suas terras. Um testemunho apresentado por Riester retrata muito bem o que os Isosenõs pensavam na situação de usurpação de suas terras: "Si la gente tiene otras costumbres te quitan la tierra, tú vives como esclavo, tu sudor mesclado con tus lágrimas caen sobre tu propia tierra". As lideranças do Isoso não ficaram de braços cruzados diante do avanço dos "brancos" sobre sua área, trataram de se relacionar com os governantes em Santa Cruz de La Sierra. Combès afirma que as reclamações legais diante das autoridades bolivianas não conseguiam êxito algum, poisas autoridades que recebiam as reclamações, na realidade, eram as mesmas pessoas que estavam invadindo as terras do Isoso.

No início do século XX, o Isoso era dominado por grande quantidade de fazendas de gado, que representavam os interesses particulares dos "brancos" na região. Nesse momento, os Isoseños careciam de uma organização política forte que pudesse defender seus interesses. A partir de 1927, Casiano Barrientos assumiu o cargo de Capitão Grande. Foi sob sua liderança que o Isoso se viu inserido nas movimentações para a guerra vindoura. No retorno de uma viagem a La Paz, para cuidar de trâmites de questões agrárias, Casiano usa a mão de obra indígena para a abertura de um caminho que iria ligar Charagua até o Isoso, além de outras trilhas ao Norte e ao Sul do Isoso. Segundo os testemunhos apresentados por Combès, Casiano estava sendo visto pelos seus como um capataz a serviço do Estado boliviano e dos karai, pois, à medida que recrutava homens Isoseños para abertura de caminhos e outros serviços, estaria cumprindo as ordens das autoridades governamentais no sentido de preparar o terreno para a guerra. O testemunho de Rosendo Méndez, apresentado por Combès, expõe as acusações a Casiano Barrientos:

Por esto de mandar hombres a la línea, entre algunos de los hombres ya se escuchan rumores, porque él es karai, por esto no nos defiende y no nos guía, se alió con los karai para mandarnos a trabajar para ellos. Así habló la gente.

A respeito da situação de Casiano Barrientos e sua relação com os paraguaios, Combès observa que, no início de 1935, ocorreu uma grande ofensiva paraguaia sobre a região do rio Parapetí. Porém, a ofensiva paraguaia não teve uma justificativa militar, almejaria apenas obter gado para alimentar as tropas e obter cavalos para os deslocamentos pelo Chaco. Por outro lado, o testemunho de Ángel Rivero, apresentado pela autora, afirma que o exército paraguaio foi chamado ao Isoso pelos opositores de 
Casiano. Os militares paraguaios, segundo os relatos apresentados por Combès, afirmavam que os habitantes guaranis do Isoso Ihes receberam como irmãos, oferecendo seus cavalos e bois. Nesse sentido, afirmam que Casiano se empenhou em celebrar o reencontro entre os hermanos guaranisda mesma maneira. A intenção dos opositores de Casiano era demonstrar aos militares paraguaios que ele não era um hermano, mas sim um karai que estava do lado boliviano no conflito, portanto, não era defensor da "causa guarani”. Desse modo, os opositores pediram aos paraguaios que matassem Casiano. Para Combès, ao revistarem a casa de Casiano, os militares paraguaios encontraram papéis que confirmavam a luta dele em prol dos indígenas da região diante do avanço particular sobre as terras do Isoso. Após o fato, Casiano é convidado pelos oficiais paraguaios a ir até Assunção para fazer um contato com o Presidente paraguaio. O que era uma oportunidade de salvação se tornaria o motivo de sua morte. A atitude de ir à Assunção juntamente com militares paraguaios seria considerada pelos militares bolivianos como traição à pátria. Devido à intensificação da presença militar no Isoso, em 1935, seus habitantes fugiram para o Norte argentino e para o Paraguai. Muitos Isoseños que migraram para o Paraguai não retornaram à região após o conflito, seguiram vivendo em comunidades que ficaram conhecidas como Guarayos ou Guaraní Ocidentais. A ideia de Casiano era de habitar o Isoso novamente. Assim, ele retorna, sendo fuzilado em 12 de outubro de 1936 por Julio Ortiz, um mestiço Isoseño.

O avanço dos "brancos" sobre as terras do Isoso inseriu a noção de fronteira ligada ao Estado-nação e de propriedade privada, fato que se intensificou com a guerra, pois a presença maciça dos Estados no Chaco concretizou essa situação. Nesse sentido, entendemos que as noções de fronteira e limites foram sendo desenvolvidas entre os Isoseños ao longo do contato com os "brancos". O período da guerra parece ter intensificado essa ideia no cotidiano do Isoso. Levando em consideração que os Isoseños eram arregimentados para executar trabalhos secundários, como abertura de caminhos, localização de água, até podemos entender que o desenvolvimento de um sentido de pertencimento seria algo distante. Contudo, observando alguns testemunhos que nos chegam através de Riester sobre uma comparação entre os soldados collas e Isoseños, é possível verificar uma certa aproximação desses com o Estado boliviano. Riester destaca que o exército boliviano tomou a decisão deque os Isoseños não seriam utilizados como soldados, ou seja, que não seriam arregimentados para o combate e, portanto, não receberiam uniformes. Desse modo, os relatos testemunham que, quando a guerra avançou sobre a região, no final do ano de 1934 e início de 1935, não faltaram piadas dos 
Isoseños com relação aos soldados do altiplano afirmando que estes não sabiam lutar e que eram covardes:

Mire patrón, estamos mal nos han avanzados, nuestro ejército no saben combatir, entonces el finado Boni dijo; por eso es que estos no nos quieren dar gorras porque no sabemos manejar armas, decía. Pero ¿Quién tiene la culpa? Sólo las autoridades tienen la culpa.

Imagínese, si desde más antes los blancos nos reconocieran como bolivianos, nunca íbamos a perder. Porque nosotros éramos más valientes. Yo ahora reconozco eso, actualmente al recordarme de aquellos tiempos que nuestros abuelos cuando eran puros guerreros natos, y realmente eran valientes.

Todavia, existem relatos que falam de combatentes Isoseños. Combater pelo exército era uma estratégia para aqueles que optavam por não migrar para outras regiões. No relato abaixo, o testemunho fala da diferença dos disparos dos soldados do altiplano e dos Isoseños:

Dicen que algunos disparaban su arma al aire, y eso los sabían muy bien los enemigos, cuando sienten que las balas pasaban muy alto: ¡Ah, estos son collas! Pero si las balas van bien bajito: ¡Ah, estos son los hermanos! dicen. $[\ldots]$.

O termo hermanos utilizado no testemunho acima levanta outra questão a ser discutida em relação aos Isoseños: a aproximação deles com os paraguaios devido à proximidade linguística. Muitos Isoseños aderiram à imigração para o Paraguai como estratégia ao conflito, seja voluntariamente, seja como prisioneiros. Para Riester, entre 2.500 e 5.000 Isoseños estiveram nessa situação. Os paraguaios falavam muito bem a língua dos Isoseños, próxima do guarani, não encontravam dificuldade em se comunicar. Assim, muitos Isoseños migraram para o Paraguai e por lá permaneceram ao término da guerra, incentivados pela promessa de ganhar terras, gado e cidadania por parte dos paraguaios. No entanto, nem todos permaneceram por lá. A dificuldade de se adaptar em outra terra trazia à tona a identidade Isoseña ligada às terras de origem.

\section{Considerações finais}

Abordamos, brevemente, a Guerra do Chaco através de duas principais questões que fazem parte das narrativas desse fato histórico ocorrido na primeira metade do século XX com os dois países mais pobres da América do Sul. A primeira questão discutida foi o ocultamento da participação indígena na guerra em algumas narrativas históricas. A segunda questão foi a contraposição ao ocultamento, através de narrativas que evidenciam 
a visibilidade e o protagonismo dos indígenas locais. Como exemplo, apresentamos a breve história do sargento Tarija, membro da etnia Nivaclé, além das principais alterações ocorridas no âmbito dos grupos habitantes do Isoso chaquenho.

As produções que ocultam a participação indígena em seus textos usam como referência o processo de homogeneização das diferenças culturais executadas pelos Estados nacionais durante o processo de construção de identidade coletiva e de sentimento de pertencimento nos séculos XIX e XX. Esse processo procurou eliminar qualquer forma de diversidade que fizesse contraposição aos interesses nacionais. Assim, alguns textos históricos que escrevem a história indígena na América utilizam termos como "raça" para identificar e categorizar os diversos grupos indígenas. Em contraposição, novas produções estão revendo a história indígena da América, procurando evidenciar a visibilidade indígena, ou seja, repensando acontecimentos a partir da heterogeneidade e da multiplicidade cultural, assegurando a posição de atores aos indígenas.

Os processos de contato de grupos indígenas chaquenhos com militares e "brancos" permitem visualizar, já desde o final da segunda metade do século XIX, uma complexa rede de relações pessoais entre culturas distintas no ambiente do Chaco. Toda a região foi afetada pela presença do "outro", de maneira que todos os grupos, de alguma forma, sofreram as transformações provocadas com a chegada de outra cultura, fato que começou a se intensificar nos anos anteriores à guerra. Portanto, o processo histórico de contato a que os indígenas chaquenhos estiveram submetidos, principalmente, durante o final da década de 1920 e anos posteriores a 1935, foi determinante para seu destino. Muito longe desse contato ter se constituído como uma oposição entre dominantes e dominados, foi, na realidade, uma complexa rede de relações em que as práticas desenvolvidas pelos indígenas não foram apenas de aculturação ou resistência. Eles não se anularam diante das práticas desenvolvidas pelos dois Estados, souberam desenvolver estratégias para amenizar perdas e obter ganhos com a relação estabelecida.

Todavia, pelas narrativas que nos chegam, através dos diversos autores trabalhados, dos diversos grupos chaquenhos durante a guerra, podemos observar que as perdas foram muito maiores que os ganhos obtidos. Nenhum grupo habitante da região ficou imune às consequências trazidas pela ocupação do território.

Por fim, a guerra do Chaco e o contato constante entre os grupos indígenas habitantes da região e as diferentes culturas que passaram a fazer parte do ambiente desde antes de 1932 trouxeram importantes implicações para a fronteira chaquenha. A ocupação da região integrou, definitivamente, o espaço ao território nacional dos dois Estados. Os grupos que após a guerra continuaram habitando a região, seja nas missões, seja nas 
colônias privadas, seja no âmbito dos próprios grupos, passaram a fazer parte do espaço nacional. Como afirma Boccara, múltiplos processos de mestiçagem levaram sociedades a serem capazes de desenvolver estratégias e práticas que desembocaram na aparição de nuevos mundos en el Nuevo Mundo. Os indígenas chaquenhos se lançaram em uma nova história. Seja com o tempo mais lento dos anos anteriores à guerra, seja com sua aceleração entre 1932 e 1935, o contato com o "outro" constituiu um elemento transformador que reestruturou o ambiente do Chaco.

\section{Referências}

BARBOSA, Pablo; RICHARD, Nicolás. La danza del cautivo. Figuras nivaclés de la ocupación del Chaco. In: CAPDEVILA, Luc; COMBĖS, Isabelle; RICHARD, Nicolás; BARBOSA, Pablo. Los hombres transparentes. indígenas y militares en la guerra del Chaco (1932-1935). Cochabamba: Instituto de Misionología, 2010, p. 121-166.

BEJARANO, Ramón César. Antecedentes de la guerra con Bolivia. Asunción: Casa Editorial Toledo, 1959.

BOCCARA, Guillaume (editor). Colonización, Resistencia y Mestizaje en las Américas (siglos XVI-XX). Quito: Edições Abya-Yala, 2002.

BOSSERT, Federico; COMBÈS, Isabelle; VILLAR, Diego. La Guerra del Chaco entre los chané e isoseños del Chaco occidental. In: RICHARD, Nicolas (comp.). Mala Guerra: Los indígenas en la Guerra del Chaco (1932-1935). Asunción \& Paris: Museo del Barro, ServiLibros \& CoLibris, 2008, p. 203-234.

BREMEN, Volker Von. Impactos de la Guerra del Chaco en la territorialidad ayorea. In: RICHARD, Nicolas (comp.). Mala Guerra: Los indígenas em la Guerra del Chaco (19321935). Asunción \& Paris: Museo del Barro, ServiLibros \& CoLibris, 2008, p. 333-354.

CAPDEVILA, Luc; COMBÈS, Isabelle; RICHARD, Nicolás; BARBOSA, Pablo. Los hombres transparentes. indígenas y militares en la guerra del Chaco (1932-1935). Cochabamba: Instituto de Misionología, 2010.

CHIARAMONTE, José Carlos. Nación y Estado en Iberoamérica: el lenguaje político en tiempos de las independencias. Buenos Aires: Sudamericana, 2004.

COMBÈS, Isabelle. El Coronel Ayoroa y los indios del lugar. In: CAPDEVILA, Luc; COMBÈS, Isabelle; RICHARD, Nicolás; BARBOSA, Pablo. Los hombres transparentes. indígenas y militares en la guerra del Chaco (1932-1935). Cochabamba: Instituto de Misionología, 2010, p. 33-82.

DALLA-CORTE, Gabriela Caballero. La Guerra del Chaco: ciudadanía, Estado y Nación en el siglo XX. La crónica fotográfica de Carlos de Sanctis. Asunção: prohistoria edições, 2010. 
FRITZ, Miguel. Indígenas ya la Guerra del Chaco. Lo impacto de lo indicible. In: RICHARD, Nicolas (comp.). Mala Guerra: Los indígenas en la Guerra del Chaco (1932-1935). Asunción \& Paris: Museo del Barro, ServiLibros \& CoLibris, 2008, p. 149-170.

GRANIER, Juan Chirveches. Diario de campaña: fragmento de una vida patriótica en la Guerra del Chaco. La Paz: Ah! Publicidad, 2004.

MESA, José de; MESA, Carlos; e GISBERT, Teresa. Historia de Bolivia. 7. Ed. La Paz: Editorial Gisbert y Cia, 2008.

PAMPLONA, Marco A.; DOYLE, Don H. (Org.) Nacionalismo no novo mundo: a formação de Estados-nação no século XIX. Rio de Janeiro: Record, 2008.

PUENTE, Rafael Calvo. Recuperando la memoria: una historia crítica de Bolivia. Tomo 1. Santa Cruz: Fundación Colonial Pirai, 2011.

QUEREJAZU, Roberto Calvo. Historia de la guerra del Chaco. La Paz: Librería Editorial Juventud, 1998.

RATTO, Silvia. Rompecabezas para armar: el estudio de la vida cotidiana en un ámbito fronterizo.In: Memoria Americana. Buenos Aires: 13, 2005, p. 179-207.

RICHARD, Nicolas (comp.). Mala Guerra: Los indígenas em 98e Guerra 98el Chaco (19321935). Asunción \& Paris: Museo 98el Barro, ServiLibros \& CoLibris, 2008.

RIESTER, Jürgen. lyambae - Ser Libre: La Guerra del Chaco en la memoria indígena isoseña. In: RICHARD, Nicolas (comp.). Mala Guerra: Los indígenas en la Guerra del Chaco (1932-1935). Asunción \& Paris: Museo del Barro, ServiLibros \& CoLibris, 2008, p. 183-202.

RONCAYOLO, Marcel. Território. In: ENCICLOPÉDIA EINAUDI. Região. Porto: Imprensa Nacional/Casa da Moeda, 1986. V. 08, p. 262-290.

SENA, Ernesto Cerveira de. De colônias a início dos Estados nacionais: considerações sobre as fronteiras entre Brasil e Bolívia. Revista Territórios \& Fronteiras, Cuiabá, MT, v. 5, n. 2, p. 144-130, Jul./ Dez. 2013.

SOUZA, Marcelo Lopes. "Território" da divergência (e da confusão): Em torno das imprecisas fronteiras de um conceito fundamental. In: SAQUET, Marcos Aurélio (Org.) Territórios e territorialidades: teorias, processos e conflitos. São Paulo: Expressão Popular: UNESP, 2009. 


\section{Capítulo 06 "CIRCULANDO A TRAVÉS DEL CALOR: UNA ETNOGRAFÍA SOBRE EL FUEGO Y LA COCINA EN LOS MISAK-GUAMBIANOS"}

\section{DUVAN MURILLO ESCOBAR}

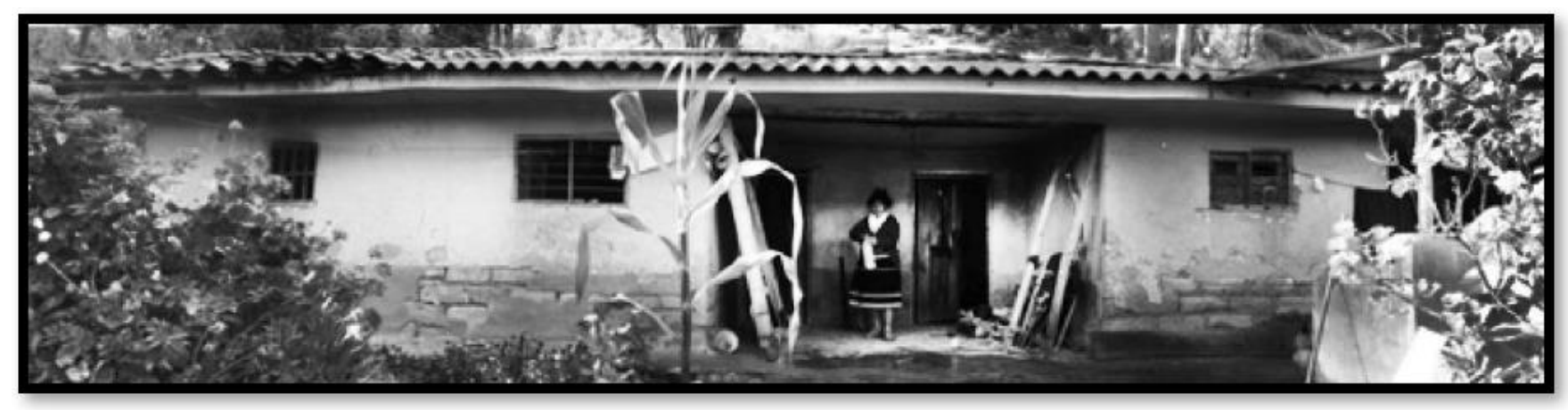

Pishimisak quería ser mama, e Kallim taita, así quisieron conformar la familia. Se unieron y nacieron dos niños, los piurek... ellos fueron criados para ser autoridad, al niño lo llamaron Peretsik que significa vara de mando, y a la niña Isik tsik, que es tejedora: de la vida, del territorio... Kallim formó el nak chak y siempre soplaba la candela para mantener el fogón ardiendo. Fue así que ellos recibieron la autoridad para gobernar [...]

Javier Morales Troches.

Bajo la penumbra de la extensa neblina me ha sorprendido un torrente de viento y lluvia que cae con firmeza sobre un inestable tejado de zinc, la furia que escucho sobre mi cabeza pareciera que anuncia la presencia de un tornado de páramo ${ }^{1}$. Este día ha sido largo, sobre las 15:00 una tormenta se apoderó de la pasiva Villa Nueva, mi nuevo espacio de residencia, en cercanías de Piendamó.

Este espacio tiene una particularidad, ayuda a desplegar mi sensibilidad y me incita a dar atención a lo cotidiano, creo que se debe a que siento de cerca un ambiente "familiar". Es exactamente lo que he venido intentando rastrear últimamente en Guambía, me refiero a las dinámicas sociales alrededor de la cocina y el calor del fogón. La familia Morales se reúne cada noche para compartir experiencias, sus narrativas van desde relatos que recuerdan la vida de sus ancestros, hasta lo acontecido en el día de trabajo en medio de la cosecha de café. Enseñanzas, consejos y regaños van y vienen desde los abuelos con parciales interrupciones de los demás. 
En momentos de lluvia es común la reunión familiar, tanto como los alimentos cocidos en el fuego. Escucho risas sonoras, y en algunos casos, susurros misteriosos. A veces me miran y se ríen, en algunos casos me explican, cuando es necesario me traducen, $y$ en otros momentos simplemente y tras algunos momentos de silencio, me dejan a voluntad para yo discernir sus palabras y expresiones.

En medio de las visitas a múltiples viviendas en busca de las palabras y versiones de los taitas, mamas y mayores misak, me he encontrado frecuentemente en medio del nak chak, sintiéndome envuelto en una dinámica discursiva que practican los misak, lo cual deja en claro porque son un pueblo basado en la narrativa oral, siendo que sus relatos describen sus interpretaciones cosmológicas y los hechos históricos que han definido y transformado sus condiciones de vida.

He llegado a identificar que el fuego para los misak, como elemento aislado no cobra mucho sentido, pero si se sitúa en relación a otros aspectos que integran la cocina, se convierte en uno de los aspectos más atenuantes en la vida de esta sociedad: el fuego acompañado de tres pangos (columnas) es nak kuk; y el espacio de reunión -normalmente una cocina- integrada por múltiples utensilios en su mayoría usados para cocinar, se denomina nak chak.

Hace unos días hablando con Javier Morales, indagaba sobre la importancia que tiene para los misak el nak kuk y nak chak, mi interlocutor rápidamente desglosó una versión con múltiples connotaciones, explicando que allí mismo se pone en interacción la alimentación, el cuidado del cuerpo, el consejo y el aprendizaje de cada persona, pero también de la familia, y aún, en el ámbito comunal. Javier comenzó definiendo:

\footnotetext{
¿el nak? está ahí... siempre el nak está ahí...es la llama que se aviva con los leños y es parte de la base principal de la existencia del ser misak. Pero para que lo entiendas, también es eso que tú ves ahí en el suelo: nak chak es el espacio físico en donde están las vasijas de barro, las ollas todos los elementos de cocina. Y en el nak kuk, que sería el fogón, tienen que estar tres cosas: primero los pingos ¡los tres pingos! luego tiene que estar la ceniza y la leña, luego tiene que estar algo de candela y de ahí salen las llamas. Después de esto tiene que estar la olla de barro. Ahí ya se puede cocinar... entonces en su alrededor se sienta la familia, todo esto es el nak chak, que incluye también el nak kuk.
}

De esta forma, el nak chak se instala en un contexto polisémico, la apreciación de Javier coloca esta categoría en un nivel de relaciones complejas que en principio sugiere dos ámbitos: por un lado, indica la posición física que ocupa el nak chak, determinado bajo ciertas características físicas y objetos que le componen; y por otro, comienza mencionando que es parte "existencial" del misak, sugiriendo un papel fundamental en la estructura social de esta etnia. Tras un prolongado análisis sobre las reuniones de los misak, en donde he intentado determinar la formación de la persona, así como la conformación de las relaciones colectivas y sus trayectorias, sugiero en este 
trabajo que, las cocinas -o mejor aún- el nak chak, acaba tejiendo un sistema de redes sociales que hace operacionales y dinámicos los principales aspectos de la vida de los misak, otorgándole continuidad a esta sociedad indígena. Taita Julio Tumiñá, Sugiere una connotación adicional:

\footnotetext{
El fuego misak se puede manejar incluso desde las plantas: la planta tiene aire, tiene agua, tiene fuego. ¡todas las plantas!

Y el agua lo mismo: el agua tiene fuego, el fuego está en el agua... todo es un fuego que calienta y el misak tiene ese calor que es necesario para el equilibrio [...]
}

Aunque el taita no se refiera exactamente al espacio del nak chak (cocina), en tanto que se refiere textualmente al fuego como elemento primario, sí hace referencia al calor que proviene de éste y que por supuesto está presente en el nak kuk (fogón). Es decir: el calor producido por el fuego sería un componente fundamental para el flujo y equilibrio de cualquier ambito. Además, es interesante analizar la idea de que en todos los elementos hay fuego, o mejor, todo contiene una porción de fuego, pues sugiere también que, el equilibrio es emanado de la interrelación de varios ámbitos. Lo cual, remite nuevamente a pensar en la importancia que puede llegar a tener para un misak el calor del nak chak.

También dice taita Julio: "el nak kuk (fogón) es como un ser vivo, como un mayor que guarda la memoria del pueblo misak y quienes se sientan a su alrededor heredan el conocimiento propio". Esto reafirma la idea de que el calor otorga una particularidad socio cultural al pueblo misak. Tanto el elemento en sí como el espacio que se le atribuye, acaban siendo columnas vertebrales en la definición de cada persona, y aún, de la comunidad.

Javier Morales define también el nak como un ser. Este crece, se alegra, enseña, cura, es decir, interactúa como un factor dinámico. Sin embargo, mi interlocutor le otorga una sobre-naturalización.

Nak musik, es el elemento principal para sostener a la familia... él la sustenta a nivel armónico y a nivel de la convivencia y unidad. El nak musik hace que el papá, la mamá y el hijo se reúnan en el núcleo familiar. Como es espíritu, hace pensar, hace imaginar, crea la necesidad de ese nak... la necesidad de concentrarse ahí...como que atrae.

Tras una pregunta simple sobre el nak chak, acabé descubriendo que a veces se hace alegoría al fuego como a un espíritu mayor, un espíritu que contiene sabiduría milenaria y tiene la capacidad de atraer a la familia con su calor, asegurando su reunión y constante unidad. Además, el fogón no sólo es entendido como un ser vivo, sino que, es un ser mayor: un espíritu fundamental en la estructura social misak, un ser que conduce uno de los ámbitos fundamentales concernientes al nak chak: me refiero a la reunión familiar. 


\section{Cuidados y salud}

Pasé el día acompañando a mama Agustina, hablamos durante horas, ella es una enorme referencia de consulta que no cede ante el cansancio. La educación, la Misak universidad, el fogón, la recuperación de tierras, han sido los temas predilectos. Fue una tarde-noche especial para escuchar los relatos de una mujer que abre su corazón y pensamiento para rememorar las vivencias de sus padres y los sueños que le han guiado durante su vida. Siempre en el nak chak sentados, es así como le enseñaron sus abuelos a mama Agustina "las conversaciones sobre la cultura propia deben tejerse alrededor de este espacio para que tengan un soporte y hagan sentido", dice ella.

Agustina es partera y curandera, para una mujer como ella, cuyo manejo de las plantas se basa en el atendimiento de los partos, es intrínseco que relacione la cocina y el fogón a los cuidados del cuerpo. Por eso el nak chak, dice: "está lleno de prevenciones".

Los misak consideran que el cuerpo depende del calor. Tal parece, la salud de cada persona está sustentada por aspectos que intervienen en el nak chak: el alimento, las prevenciones y la aplicación de plantas pasan por el mismo espacio. Queriendo entender este aspecto, indagué un poco más sobre dicha ligación, sin haber concluido mi pregunta, mama Agustina interrumpe para enfatizar en un dato clave: "[...] El nak chak, por todo... es principal: ¡Tanto que la placenta se coloca allí cuando nace el niño!”.

Los partos son realizados en el nak chak, y posterior al nacimiento, la placenta y el cordón umbilical son enterrados bajo el nak kuk, esto demuestra la ligación de los misak recién nacidos con su fuego, con su calor. A su vez que, puede interpretarse que dicha ligación está en el ámbito cíclico que rodea la vida y la muerte, en tanto que el nak chak (como explicaré más adelante) simboliza un punto de origen y un punto de retorno.

Adicionalmente, en el nak chak existen múltiples advertencias que van desde lo más simple a lo más complejo en la medida que el fuego manifiesta múltiples señales a través de sus formas, apariencias, movimientos y colores, cada interpretación indica un acontecimiento en la salud de los parientes o alguna predicción hacia el futuro. Puede decirse que el fuego además de ser un ente vivo, tiene un lenguaje preventivo, teniendo en cada etapa un indicador relativo.

Cuando nosotros estamos alrededor del fogón, nosotros estamos hablando cuando hay buena candela, cuando estamos haciendo una fogata con buena leña. Entonces el fuego a veces da chispas cuando estamos cocinando, a veces el fuego hace como un soplo ¡no como ardiendo para arriba! sino que el fuego hace una bulla como si estuviera soplando. Entonces siempre 
decían:...jalguien murió! entonces el fuego siempre está avisando. Hace como llorando, parecido a llorar hace el fuego... (silencio)

Mi papá sabía decir ¿qué? Que mañana vamos a ver quién llega o quien trae mala noticia, entonces alguien ahí estaba viendo...y al ratico no más, por la mañana llega corriendo: "que pasó algo por allí", o llega diciendo: "hay un enfermo grave", entonces el fuego avisa faltando un día, entonces como que él decía que era prevención y también era como alertando.

Incluso, en palabras de la mayora, el fuego interpela en el acto señalando o prediciendo alguna situación que sufrirá la persona señalada.

Hay otra forma también: las chispas, hay unas leñas que no hacen ningún ruido, no dan ninguna chispa, y aun así el fuego comienza a dar mucha chispa para el lado donde está la persona, y siempre dicen: "No, a vusté, a vusté le va a pasar algo" o "mañana alguien te va a venir a dar problema", entonces eso, ahí mismo como que el fuego le está enseñando, le está previniendo, entonces eso es lo que pasa con el fuego, son advertencias.

Otro aspecto en el cual enfatiza mama Agustina concierne al de las correcciones y tratamientos.

A veces sale como un poquito húmeda la leña: está quemando y sale como una salivita, está saliendo agua, como saliva, entonces al niño que orina mucho en la cama siempre esa salivita de la leña tiene que untar en todo el ombligo, entonces el niño deja de orinar en la cama. Esa también es una parte del fuego, pues yo creo que lo corrige.

De tal forma que los cuidados y parte de la salud en el pueblo misak pasan por el nak chak, siendo éste el centro de los nacimientos, cuidados, prevenciones, advertencias, correcciones y el Kørøsrøp". Mama Agustina al ser partera, delimita múltiples prevenciones que pasan por la definición de la persona y el cuerpo, y, por la relación familiar, ya que como ella dice "hay situaciones en las que una persona puede enfermar y otras en las que una persona puede causar que su familia enferme".

\section{Tríade}

Compartir con una familia en una cocina suele ser más interesante que acompañar clases en alguna escuela o en la Misak universidad esperando a que los profesores y estudiantes conversen. Las sopas de maíz y hortalizas o el café cargado de azúcar con masitas de trigo, a menudo han sido el preámbulo para un enriquecedor ejercicio narrativo. El nak chak es un espacio ideal para conversar, porque los mayores, los abuelos o los 
Mørøpik-médicos tradicionales hablan sin restricción, pero también los hijos intervienen e incluso el invitado extraño acaba dejando alguna reflexión. No quiero decir que las conversaciones en este espacio sean siempre profundas, pues la cotidianidad de los misak -así como la de cualquier otra sociedad- está cargada de elementos rutinarios que se reducen a la siembra, la cosecha, el comercio y los chismes; sin embargo, acaba siendo el escenario por excelencia para entender las formas de vida de este pueblo nativo.

Durante mi trabajo de campo algunas visitas me han marcado más que otras, en tanto que han sido extremamente productivas para mi pesquisa, otras simplemente han sido un momento de relajación y risas, sin embargo, todas han tenido algo en común: he tenido que sentarme en algún banquito en el nak chak, cerca del fuego para calentarme y con las manos libres para recibir los alimentos que me ofrecen (nunca faltan, y sería mal visto para el anfitrión no ofrecer nada, así como para mí no recibirlo); y por supuesto, ha sido un ambiente familiar. Dice el taita Efraín tras ser consultado: "en el fogón se toman todo tipo de decisiones, desde un consejo o un cuidado básico para un niño, hasta la autorización para la unión de una pareja en matrimonio, la familia va siendo sustentada en el nak chak en cada generación".

El nak chak y la familia son uno sólo, ya que así como el fuego de facto hace reunir a las personas, simbólicamente también les representa: dentro de la filosofía misak no se concibe una familia sin cocina y fogón en donde puedan reunirse. En las casas misak no hay salas o comedores, todo gira entorno de la cocina y los cuartos son destinados apenas para la privacidad de cada pareja. Los misak consideran que la familia debe mantenerse activa y en comunión, ya que así como el fogón necesita ser alimentado a través de leña para que las llamas se mantengan, la familia también debe ser cuidada y sustentada.

La idea de pensar en una familia conformada por padres e hijos, parece común a la de cualquier otra sociedad occidental, y efectivamente lo es: en los misak se practica la monogamia y se entiende que así como en el mito de origen Pishimisak y Kallym eran femenino y masculino, el parentesco comienza por un hombre y una mujer, ya que así se garantiza la reproducción. Dada esta forma de organización social, puede inferirse que los misak ponen en función la dualidad. Dice taita Julio Tumiñá:

[...] ese origen del Pishimisak y Kallim, esos dos aroiris, las dos lagunas, esa dualidad que lleva en el mundo natural son reales ison muy reales! de allí es que viene el misak: desde las lagunas...Y entonces ahí es que ya se forma la dualidad natural, la dualidad de la espiritualidad, la dualidad del territorio, todo es dualidad, por ejemplo: miremos cual es la tierra macho y la tierra hembra, el agua macho y el agua hembra jahí está todo! 
Sin embargo, en una segunda reflexión taita Julio aclara que en un comienzo es dualidad pero después se vuelve sobre un punto elemental de la cosmología misak, el cual se refiere a la conformación en tríade. Así como Pishimisak y Kallim fueron dualidad al comienzo, después nacieron los Piurek, sus hijos. El tercer ámbito concierne entonces a los hijos que nacen de la unión masculino femenino.

Se forma la pareja y ya va a llegar otra vez el número tres, por ejemplo yo voy y pregunto a un niño...(inentendible) entonces el nak chak y la familia están compuestos por tres. Entonces desde ahí se va cogiendo que va a formar desde una familia hacia otras familias.

De acuerdo con lo que he presentado hasta aquí, los elementos más básicos como la alimentación, el calor -entendiéndolo en lo físico y simbólico, la socialización y confraternización, el cuidado del cuerpo, las correcciones e incluso los partos están ligados al mismo ámbito. Sin embargo, la interconexión del nak chak con la conformación de tríade, extrapola la discusión a un nivel superior, luego que la familia además de ser un componente primario, es también un sinónimo de autoridad, puesto que los primeros seres que instituyen la dualidad son también madre de tejidos (Pishimisak) y bastón de mando (Kallim), son los padres del pueblo y son los proveedores del Nu-pirau (gran territorio). Así que vale preguntarse si en su sistema cosmológico, los misak entienden a la familia únicamente desde el ámbito padre-madre-hijo del que he venido hablando hasta aquí, o evocan otro ámbito que puede ser entendido como un escenario mayor, pero que se rige a través de las mismas reglas que componen a una familia.

\section{Territorio y las espirales}

¿Cuantos guambianos confluyen los martes a la gran galería de Silvia? Deben ser por lo menos cinco mil. Al recorrer las principales calles del pueblo, una enorme manifestación de colores adorna los espacios que rutinariamente sucumben ante la frialdad del clima y los silvianos. Desde allí comencé mi odisea, una cansadora caminata morro arriba durante un par de horas a través de las montañas del Chimán, un recorrido que fue transitado miles de veces por guambianos sometidos a la Terrajería, allí fue el epicentro de este modo de producción al que se vieron sometidos los misak. En la parte alta del Chimán se encuentra un caserío, es allí en donde habita taita Efraín. Ha sido un día de esfuerzos recompensados, con algo de lluvia y un poco de viento, un día de recuerdos, de múltiples 
caminos y aprendizajes, la palabra de Efraín ha sido como una pausa para la reflexión, mostrándome múltiples caminos y nuevos aportes para mi investigación.

Una vez sentado con Efraín, este ha hecho una aproximación a una múltiple connotación simbólica sobre el nak chak, ya que, según su explicación, representa a la familia y aún más: "todo mandato sale del nak chak, por eso se habla de autoridad, porque ahí se ordena la familia y se ordena el gobierno propio, que está en el territorio".

Puede decirse que hay dos unidades que ordenan al pueblo misak, por un lado, está la familia como ya he mencionado, y por el otro, el gobierno propio (en cabeza del cabildo indígena) que organiza el territorio físico ${ }^{1}$. Las dos unidades están precedidas por la visión del fuego y su definición específica en el nak chak. Es por esto que debe identificarse a dicho espacio como la matriz de la autoridad misak y el kørøsrøp. Además, dice Efraín: "las tulpas o pingos ${ }^{1}$ indican el sostén del territorio, así como son base en el fogón, representan también la base de todo el territorio. Todo mandato debe ser sostenido y salir de allí en armonía, es el kambaguan"”.

De tal forma que los pingos además de ser la base del fogón, representan el soporte del territorio y son fuente de apoyo para quienes le gobiernan. Taita Julio confirma la misma interpretación a través de un par de preguntas:

- Taita para aclarar: ¿los tres pingos del fogón simbolizan a la familia?

- ¡Sí!

- ¿Qué otra interpretación hay?

- Sostienen a la familia y al territorio, cuando hay familia se sostiene el territorio.

Mi día fue arduo, subí hasta los cerros encima de Pueblito y descendí hasta los límites del Resguardo en Tranal. Allí observé los petroglifos que yacen en algunas rocas y pequeñas cavernas. En ellos se expresan múltiples figuras que se desdoblan y entrelazan unas con otras como si fueran mapas codificados que condensan el pensamiento de los antiguos habitantes de esta región. Destaca que algunos de ellos son espirales, y llama la atención que de allí han surgido varios marcos de interpretación cosmológica que tienen fuerza hoy en día en el pensamiento de los misak. Para este análisis traeré dos categorías que son abordadas en el sistema cosmológico de este pueblo y que irán a permitirme una interpretación más holística sobre el nak chak. Estas son: "las espirales" (símbolo usado frecuentemente en todos los espacios de reunión y que acaba siendo un elemento importante en la definición de la identidad étnica misak); y, los "tres mundos" (categoría un poco más restricta, evocada más específicamente por los Mørøpik y mayores para referirse a los ciclos de vida que integran a un misak). Mayores como Efraín, Julio e mama Agustina 
me han explicado que los misak poseen varios ciclos de vida -aunque cotidianamente se use una flexión singular indicando como si fuera sólo uno.

La cosmología misak plantea siempre el desenrollar y el retorno, es decir, una interrelación cíclica de los principales aspectos de la vida de la persona. Con esto es posible demostrar que la familia, el territorio, los tres mundos y las espirales están íntimamente ligados a través de un sistema complejo de pensamiento que se inteligibiliza a través de los distintos medios de aprendizaje en esta sociedad.

Sobre los tres mundos, existen dos formas de abordarles. Por un lado, puede precisarse que para los misak existe el mundo de arriba, el mundo del medio y el mundo de abajo. En cuanto a esta definición, mama Agustina dice: "sobre los tres mundos que decimos, la parte del espacio es el Palak o, este espacio está encima. Entonces está el espacio... (silencio) entonces Pirømbø se llama el de abajo o de adentro, y el del medio Pirau: donde estamos, nuestro territorio". De acuerdo con mama Agustina, cada mundo ocupa un espacio. Adicionalmente, al respecto a dicho taita Efraín que, en todos los espacios hay espíritus naturales ${ }^{1}$, y en todos los espacios el espíritu de cada misak viaja o transita, puesto que su posición después de la muerte no es fija: "la muerte tiene un significado de viaje que se encamina al retorno". Puede decirse que la versión de Agustina y Efraín es la menos difundida.

Por otro lado, En cuanto a la segunda definición, a menudo se hace referencia a los tres mundos bajo una conceptualización política que incluye la instrumentalización de categorías modernas. Al respecto explica Javier Morales:

Para nosotros es sentir en el mundo guambiano que está comprendido por tres mundos: territorio, autonomía y la parte espiritual. Autonomía porque nosotros sabemos pensar solitos, nosotros sabemos hacer solitos, sin que nadie nos diga "haga esto", teniendo nuestra propia autonomía como debe $\operatorname{ser}[\ldots]$

Los tres mundos se identifican como Territorio, autoridad y espiritualidad, siendo una denominación difundida a través de algunos autores como Vasco (1998) y Obando (2016). Por otra parte, la relación de los tres mundos con el nak chak se remite específicamente a los tres pingos en la base del nak kuk. Javier Morales:

Bueno... primero hay que partir del nak kuk para poder entender: en el nak kuk están los tres pingos que sostienen la olla de barro, que sostienen la del café o la comidilla... entonces cada uno de esos pingos representa un mundo, por ejemplo el primer pingo representa el territorio, que dentro del territorio están los sitios sagrados, las lagunas, las montañas, los riachuelos, 
el aroiris la naturaleza... luego viene un segundo mundo que es la autonomía o la autoridad [...]

Quiere decir que un pingo está vinculado al espacio territorial, que, si se le mira de forma más amplia comprende el gran territorio misak, es decir: el antiguo nu-pirau o territorio de los piurek, los primeros misak. Por supuesto, la gobernanza está articulada a la autoridad (que como ya he expuesto, es producida en el calor del nak chak). Esto permite inferir una estrecha ligación entre los dos primeros mundos. Pero ¿como se relaciona el tercero? EI pingo de la espiritualidad está relacionado con la metafísica del pensamiento misak: "[...] empieza el ciclo de vida misak jdesde el nak kuk! ¡desde el nak chak! ...desde la pre concepción, desde la concepción, desde el nacimiento, la niñez, la juventud, adulto, vejez, muerte y regreso espiritual", precisa Javier.

Entonces son múltiples ciclos que se interconectan. Adicionalmente, Esta interpretación de los mundos ha servido como herramienta identitaria para la resignificación de los valores misak y justificar la recuperación de las tierras ocupadas desde los años 80 hasta llegar al reconocimiento bajo la figura jurídica de "resguardo indígena". Lo cual, me permite deducir que la significación de los pingos en el marco de los tres mundos, especialmente los dos primeros (territorio y autoridad), ha sido una adaptación a la imperante necesidad de demostrar la ocupación milenaria sobre esta región. Esto porque de facto, la concepción expuesta tiene una alta carga política que defiende la pose territorial, el autogobierno y el derecho a autodeterminarse.

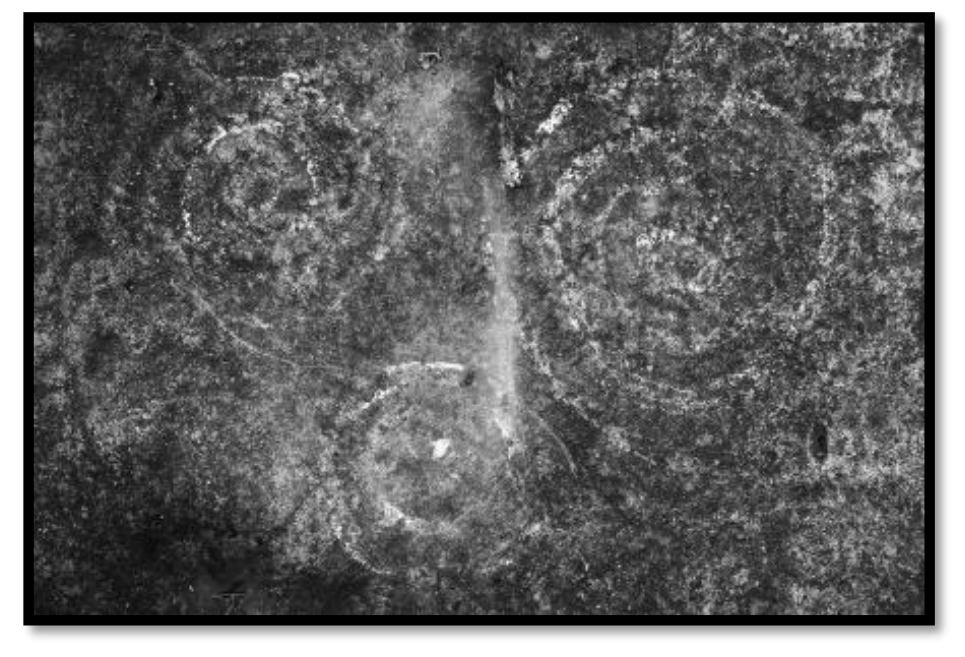

La configuración de los tres mundos está plasmada en los petroglifos de Tranal, allí se consignó este sistema cosmológico, explica Javier: 
En esta piedra nos explica los tres mundos claramente. Esos espacios, los tres espacios... entonces, esta piedra nos explica territorio, autonomía y la parte espiritual del pueblo misak, y nos explica el nak kuk. para poder entender bien la cultura guambiana tenemos que recorrer la tierra, tocar la tierra, sentir quiénes somos, ver el mundo desde la mirada ancestral. Muchos de los sitios sagrados van conectados con estas piedras, Wasrectum, las lagunas, el Wasr Tun, el Wasrø Yapalø [...]

Me parece que adicional a la connotación política que puedan tener los tres mundos en la actualidad, el tercer mundo da la pauta para entender un aspecto fundamental en los ciclos de vida de los guambianos, en tanto que, la relación del espacio-tiempo y las trayectorias espirituales por las que transita cada misak, inician -como mencionó Javierdesde el nak chak y la preconcepción de cada ser. Este aspecto lleva a la segunda categoría, concerniente a las espirales.

En las piedras de Tranal se demarcó la lógica retrospectiva del pensamiento misak, indicando los caminos a seguir y anteponiendo el pasado como si estuviera en frente. Aunque el patrón adaptativo en la cultura misak opera constantemente en continuidad, también se incluye una connotación hacia el pasado, lo cual se denomina Metrap (un futuro basado en el pasado), es por esto que los mayores del pueblo dicen que el tiempo para ellos es en espiral, ya que se desenrolla bajo un conjunto de ciclos interconectados, $\sin$ ir a desprenderse del punto céntrico, por el contrario, indicando que al final del recorrido se regresa al principio. Javier indica que el deber de las nuevas generaciones consiste en caminar usando como eje el pasado:

Donde está el papá, donde está la mamá, donde está el hijo, entonces el futuro siempre está transversal, el futuro para nosotros está atrás, desde la mirada atrás tenemos que trazar el camino para el futuro...entonces nosotros para poder educar a nuestros hijos tenemos que mirar primero lo que está atrás... Las espirales que aquí menciona esta piedra están conectadas con la forma de huella de la otra piedra, muestra que tenemos que seguir.

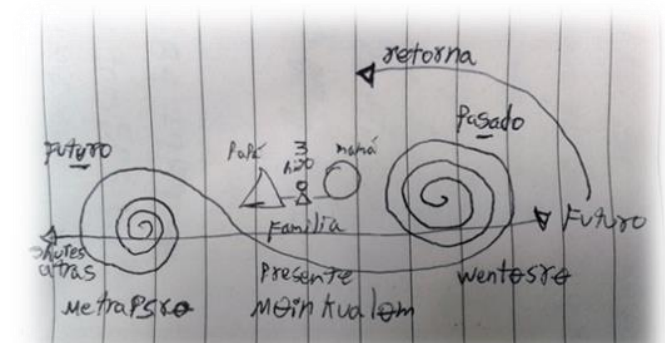

Ilustración hecha junto a Javier Morales.

La visión del espacio-tiempo indica dos momentos o espirales: el primero en el cual se desenrolla la vida de la persona misak, y el segundo, en el cual se da el retorno hacia el origen. El nak kuk se sitúa en el centro de las espirales permitiendo el flujo del ciclo o los 
ciclos de vida y soportando a la familia en cuanto hacen su tránsito. Sobre los tres mundos, estos están presentes en todo momento en la vida de los misak, ya que como dice Javier "para vivir en armonía, es necesario poseer territorio, practicar la autoridad y basarse en la espiritualidad".

La muerte hace parte de la espiral de retorno, siendo un proceso continuo de viaje en el cual el misak entra en un nuevo ciclo sin dejar de transitar entre los diferentes mundos. Incluso, el año nuevo para los misak acontece el 1 de noviembre, definido también como el día de la visita de los mayores que están en el viaje espiritual. Se acostumbra a hacer comidas a base da papa y maíz y ofrecerlas para los muertos. Kansrø, es el espacio a donde se dirigen los misak posterior a la muerte física, este espacio hace parte del proceso de aprendizaje en donde los misak permanecen por un tiempo y están en una condición de armonía plena con los seres naturales. Al respecto dice taita Julio:

Kansrø es el espacio que conecta con natural, por ejemplo, ahorita se llovizna un poquito, los mayores dicen anrak: está muriendo o se murió (quiere decir), como que se está muriendo cerquita. Ya tiene un sentido y entonces el espíritu de uno ya se conecta con el aguacero, entonces el aguacero no queda en el suelo caído, cuando calienta el sol se levanta otra vez, y hace un viaje, un viaje alrededor del mundo. Lo mismo hace el espíritu, algunos se conectan con el aguacero, el páramo, o con el arcoíris.

Sin embargo, ¿qué sucede al final de la estadía en el kansrø? o ¿posterior al viaje espiritual? el principio de la espiral indica que cada espíritu misak necesariamente tiene que continuar fluyendo en su curso, taita Julio:

Los espíritus transitan en los tres espacios: subsuelo, suelo y espacio. Entonces esos tres espacios... después de la tercera, cuarta generación, esa persona vuelve a reencarnar, pero no en la misma familia, sino en la otra...cuando hace un viaje espiritual llega a otra persona, a otra generación, en el tiempo de conectar... viajes y viajes...

De tal forma que, en el pensamiento de las espirales es necesario referirse a un regreso oportuno, posterior al tránsito en el cual el espíritu se desplaza entre varios ámbitos para rehacerse y volver. Es interesante observar como dentro del retorno se considera fundamental tener el parto en el nak chak, pues al recomenzar el proceso de vida, debe garantizarse su conexión al territorio físico a través de la siembra de la placenta y el cordón allí mismo en el nak kuk. Por otra parte, los niños cuando nacen, vienen con toda la sabiduría acumulada a lo largo del viaje espiritual, según explica Julio: 
[...] ya cuando comienzan a gatear, los niños tienen la necesidad de escuchar qué es que hay ahí adentro: entonces por dentro de la tierra hay vida, hay espíritus y el niño les escucha. El niño mira el espacio, para ellos es felicidad. Entrar en el agua, el niño quiere entrar en el agua. ¡nace contento con esa relación natural! entonces el niño se relaciona con los tres espacios.

Nu misak significa gente sabia, a los niños cuando nacen les llaman así, porque se les considera los principales portadores de la sabiduría. Los misak consideran que al nacer, los seres vienen con un conjunto de conocimientos articulados al campo natural, teniendo mayor armonía que cualquier otro misak adulto. Para taita Julio, la educación escolar es conflictiva porque acaba limitando la polimatía y reduciendo las potencialidades del nu misak.

\section{Transformaciones}

Después de múltiples visitas y acompañamientos a diferentes personajes y procesos en los Reguardos de Guambía y Pisitau, las narrativas van y vienen en el tiempo trayendo a colación versiones, adaptaciones y reinterpretaciones de la cosmología misak, e inclusive, de acontecimientos históricos que frecuentemente son recordados. El ejercicio narrativo siempre trae consigo una contextualización - y en muchos casos una aplicación - para el presente. Así por ejemplo, algunos dicen "por aquí pasó taita Ciro" (conocido en la mitología como uno de los antiguos Shures-sabios) y poco después dicen "por aquí venía mi papá a cazar, pero ahora ya no hay ni animales", interconectando las historias del presente con la rememoración de los antiguos y evocando los caminos por los que transitaron.

A menudo se da una situación de controversia en cuanto a las variaciones relacionales de una generación a otra y la forma en que éstas lidian con los contextos actuales. Mayores y conocedores de las narrativas misak y su cosmología tienden a criticar los sistemas educativos y las formaciones que procuran las generaciones más recientes. $A$ pesar de esto, el conocimiento parece fluir de forma ininterrumpida interconectando elementos de las narrativas del pasado con técnicas y tecnologías contemporáneas ${ }^{1}$.

La discusión sobre los rumbos que deben seguir los misak en cuanto a su aprendizaje es abierto y controversial, ya que existen divisiones internas representadas en por lo menos tres partes: los que consideran que la educación debe ser netamente evangélica, los que optan por la opción intercultural y los que creen que debe mantenerse el nak chak como centro de aprendizaje. Este trabajo creo que da luces al respecto, evidenciando que el nak chak es un factor decisivo en la continuidad de esta sociedad, 
otorgando un soporte a la constitución y devenir de cada persona, equilibrando la dualidad tiempo-espacio y ocupando un lugar privilegiado en la ontología del conocimiento, ya que se ubica en la génesis de la cosmología. Dice mi interlocutor Javier:

La educación debe de ser impartida desde el nak chak y las escuelas pues deben ser un aporte que hace al joven, a la niña, para complementar esa formación, esa visión, ese sueño... porque antes de cualquier escuela se debe sentir misak, ver el mundo como misak, andar como misak, relacionar como misak, convivir como misak, ese es un primer propósito. la educación escolar misak está un poco como absorbida desde el pensamiento occidental, entonces es importante que la responsabilidad directa sea de los padres y su nak kuk y nak chak de cada casa.

También dice mama Agustina:

En muchos hogares hay desorden familiar porque ya no hay equilibrio con el fuego. El fuego nunca se debería apagar... (silencio) en algunas partes se han perdido los banquillos especiales que eran de antes. Las piedras de moler junto con los banquillos los tienen botados afuera (de las casas).

Estos mayores relacionan los problemas que hay dentro del pueblo con la perdida de los valores del nak chak, ya que, de acuerdo a su visión, el alejamiento o lo que es igual a decir "dejar que el fuego se apague", causa un estado de vulnerabilidad. considero que cada aspecto tiene un riesgo: mantenerse en el aislamiento sin dialogar con las nuevas formas de aprendizaje llegadas con la modernidad y el modernismo, podría frenar la continuidad del pueblo y su necesidad primaria de mantenerse en el tiempo. Y por otra parte, ceder ante la hipnotizante dinámica de las técnicas occidentales puede causar el olvido irrecuperable de aspectos fundamentales para la tradición misak.

Es importante advertir que, a diferencia de lo que comúnmente se cree, la oralidad no constituye un conjunto de narraciones que son pasadas de unos sujetos a otros creando un campo de reproducción cultural homogénea que mantiene intactas las estructuras mitológicas o cosmológicas de cada sociedad en concreto. Por el contrario, y como sugiere Detienne (1985, pág. 53), "el mundo de la repetición es también el de la variación”. Esto indica que a pesar de existir una repetición, hay también un carácter de transformación constante en toda narrativa oral, ligado a la forma como se construyen, se transfieren y se reciben los conocimientos, recreando siempre la memoria.

Sánchez Parga (1988) ilustra dicha recreación, mostrando que la transmisión oral puede propiciar más innovación por encima de un medio escrito, criticando las apreciaciones comunes que otorgan una inmovilidad a la transferencia de saberes: 
"tendríamos que re-conceptualizar la tradición como esa creatividad y espontaneidad innovadoras, que el pasado proporciona a determinadas socio-culturas para reproducirse actualmente. Es esa misma forma de "memoria recreativa" que muy específicamente desarrollan las sociedades de tradición oral. (SÁNCHEZ PARGA, 1988, pág. 101)

El autor plantea que las sociedades amerindias poseen una acción creativa frente a la memoria colectiva. De tal forma que, la tradición oral propiciaría una forma de memorización inventiva y creativa y no, reproductiva y repetitiva. Dice el autor que, contrario a las formas creativas de las comunidades tradicionales e indígenas, la escuela desde una perspectiva formal delimita el aprendizaje a una lógica de memorización reproductiva, negando cualquier otra clase de ejercicio dinámico propio de la tradición oral (Ibíd. pág. 87).

Lo tradicional pierde valor como categoría estática y sólida, siendo necesario un abordaje más flexible para entender las dinámicas de las llamadas sociedades 0 comunidades "tradicionales", ya que lo tradicional se presenta como un elemento innovador y versátil, disolviéndose y licuándose con otras formas de vida que tal vez en poco tiempo serán tradicionales y poco después, serán reemplazadas.

Para el caso de los misak, debe entenderse primeramente, que ellos han sido expuestos desde siglos atrás a dinámicas impuestas que fueron interiorizando a lo largo del tiempo hasta reproducirlas en su vida cotidiana, constituyendo una cultura híbrida. Por tal razón, es prácticamente imposible recurrir a aspectos básicos de su aprendizaje abordándolos como estructuras puras de lo tradicional, por el contrario, en este trabajo se propone un análisis que rastrea principios de aprendizaje diferencial a los escolares, que sin ser estados puros, constituyen elementos básicos que ponen en diálogo y tensión la reproducción de las relaciones sociales. El nak chak de facto es relacionado de diferentes formas, algunos misak consideran que se perdió la "tradición" tan sólo por haberse levantado el fuego del suelo e instalado en hornillas, recientemente algunas familias han adoptado el mecanismo de estufa a gas, lo cual trae consigo una reconfiguración del espacio físico de la cocina, por cuanto ya no es necesario estar en banquillos a nivel del suelo, con esto, es posible dispensar el cuidado de la leña entre otros aspectos.

Sin embargo, los cambios en el espacio físico no han sido determinantes en las reuniones como tal, ya que los preceptos del pensamiento misak se han mantenido en los recambios intergeneracionales: el afecto por los páramos, el respeto hacia las lagunas, el cuidado de la medicina tradicional, los refrescamientos para la renovación del cuerpo y el espíritu, así como la reunión familiar y comunal en diferentes momentos dentro y fuera de la cocina, son algunos de los principales aspectos que hacen parte de la vida cotidiana (ESCOBAR, 2019). En el campo cosmológico, los misak -independiente de las 
adaptaciones- mantienen un fuerte arraigo a la concepción cíclica del tiempo ${ }^{1}$, en tanto que las creencias sobre el kansrø son a menudo mencionadas para referirse a los parientes muertos.

De acuerdo con Sánchez Parga (1988, pág. Op. Cit), las sociedades nativas andinas y posiblemente también las amazónicas poseen un carácter temporal cíclico, lo cual está claramente plasmado en los misak. Como he venido desarrollando, las espirales del pensamiento evidencian una concepción de ir y venir constante, es decir que los misak nunca permanecen en un punto único, por el contrario, subsisten a través del desplazamiento de su cuerpo y espíritu. Esta esencia cosmológica es recurrente sin importar el número de técnicas y tecnologías traídas avasallantemente por el modernismo, los ideales políticos e ideológicos contemporáneos, los sistemas educativos occidentales o incluso, las vertientes religiosas.

Dice Vasco (1998, pág. 60): «[...] ()nak chak, la cocina, con su propio centro, nak kuk, el fogón. Su importancia es tan grande que podemos decir que "el derecho nace en las cocinas", pues de allí nace y se difunde el consejo, Kørøsrøp». En su trabajo con los indígenas misak a comienzos de los 80 , Vasco ya había detectado que los mayores de la comunidad hablaban de la cocina como un ámbito especial, haciendo referencia a este como el espacio por excelencia para la transmisión de saberes: "la educación propia arrancaba de la casa, de la familia, y de allí mismo se ampliaba a lo global. De la cocina (nak chak), con la familia reunida al pie del fogón, sale el manejo de un pueblo. Y de allí viene cogiendo otro hilo: el respeto del amor" (VASCO, 2002, p. 263).

Los cambios intergeneracionales no han hecho que la autoridad emanada del nak chak disminuya, por el contrario, constantemente se recurre al ámbito familiar en las cocinas y al ámbito espiritual en el páramo y las lagunas. Los ejes que soportan las relaciones socio culturales mantienen fidelidad a los preceptos básicos de la cosmología misak y andina, en tanto que dialogan y se adaptan a los nuevos escenarios.

Una de las unidades más relevante a ser analizada en cuanto a las ontologías andinas, se refiere al flujo cíclico y continuo del tiempo, ya que, este aspecto acaba siendo determinante en las percepciones y construcciones de las prácticas sociales Carbonell (2004). En cuanto a los misak, es más adecuado referirnos al tiempo como "el movimiento de las espirales"', en tanto que en el pensamiento misak, al contrario de la visión occidentallineal, el pasado está adelante (DAGUA, TUNUBALA, VARELA , \& MOSQUERA (2005) . Vale pensar de forma alegórica en una rueda que da vueltas, volviendo siempre sobre sí misma. El tiempo va y vuelve en medio de todo, otorgando a los misak predicciones a futuro a través de la memoria del pasado (VASCO, DAGUA, \& ARANDA (1998, pág. 61). 
Es por tal razón que el mundo misak nunca acaba, pues la muerte constituye sólo una vuelta más en la espiral del tiempo-espacio, la muerte es más un desplazamiento hacia el kansrø y otro escenario para el aprendizaje y la enseñanza. La muerte está relacionada entonces con el devenir de cada misak, en tanto que los habitantes del kansrø pasan a ser una referencia de vida latente en la comunidad. Los que se fueron hacen parte del territorio y de la historia presentes, extendiendo el tiempo hasta lo atemporal hasta el primer principio y hasta el final (VASCO, 2002, pág. Op. Cit.).

Es interesante observar como la salud se relaciona también con el movimiento: cuando un misak está enfermo, es como una eternidad estática, estar enfermo es sinónimo de estar encerrado en una cárcel sin poder compartir y desempeñar las funciones vitales de la vida social (AGREDO \& MARULANDA, 1998). Lo cual remite nuevamente al tiempo, ya que, para poder transitar en él, es necesario moverse: el tiempo existe en cuanto se está en movimiento. De forma continua el tiempo remonta al nak chak, puesto que éste se encuentra situado en el medio del desplazamiento, posibilitando y garantizando los ires y venires de cada persona, del conjunto familiar y por supuesto, de la comunidad, a través de las espirales.

El nak chak mantiene una memoria hecha palabra sin la cual los misak no podrían existir, remitiéndose al Kabuchik, Undak, Keribala y Srakelia, es decir, la vara o bastón de autoridad propia, el mantener los principios y criterios de los legados que han dejado los antepasados que van adelante (FAYAD H., 2013).

El tiempo, el nak chak y las espirales están íntimamente relacionados, concediendo el soplo de vida a los misak como pueblo ancestral (ESCOBAR, 2016, pág. 141). Son estas sus raíces ontológicas y metafísicas, dinamizadas de forma perenne gracias a la cocina, siendo esta la pieza fundamental de la pedagogía ancestral para el aprendizaje.

\section{Bibliografía}

Carbonell, E. (2004). Debates acerca de la antropologia del tiempo. Barcelona: Ediciones Universitat.

Agredo, O., \& Marulanda, L. S. (1998). Vida y pensamiento guambiano. Guambía: Cabildo indígena del Resguardo de Guambía.

Dagua, A., Tunubala, G., Varela , M., \& Mosquera, E. (2005). Namui Kollimisak Merai Wam - La voz de nuestros Mayores. Popayán: Editorial Lopez.

Detienne, M. (1985). La invención de la mitología. Barcelona: Ediciones Peninsula.

Escobar, D. (2019). The Sacred Cycle of the High Peaks: Water, Life, and Thought among the Misak (Guambianos). Antípoda (34), 145-151. 
Escobar, D. (2017). Pi køtreyei utø chillimal øsikmusik tøka atrun-Del agua y el barro= aspectos sobre cosmología y aprendizaje en los Misak. Campinas: dissertação de mestrado, Unicamp.

Escobar, D. (2016). Seguimiento a la palabra: aproximación a los ejercicios de memoria y reflexión de las autoridades ancestrales indígenas en los Círculos de Palabra. Maguaré, 30(2), 121-147.

Fayad H., J. A. (2013). Rastreo de la epistémica en la cosmovisión Misak. Popayán: Universidad del Cauca.

Guambía, C. I., Usaid, \& Voca, A. (2014). III Ampliación del resguardo de Guambía para la conservación y preservación del territorio, cosmovisión y el derecho mayor del pueblo Misak. Guambía.

Obando, V. L., (2016). Pensando y educando desde el corazón de la montaña. La espiral ' de vida de Avelino Dagua Hurtado. Popayán: Universidad del Cauca.

Sanchez Parga, J. (1988). Formas de la memoria: tradición oral y escolarización. Quito: Abya Yala.

Vasco, L. G. (2002). Entre selva y páramo. Viviendo y pensando la lucha india. bogotá: Instituto colombiano de antropología e historia.

Vasco, L. G., Dagua, A., \& Aranda, M. (1998). Guambianos hijos del aroiris del agua. Bogotá: Cerec - Los Cuatro Elementos.

Von Humboldt, Instituto. (2007). Atlas de páramos de Colombia. Bogotá: Instituto Von Humboldt. 
"SUBALTERNOS DA COLONIALIDADE": DIFERENÇAS, DOMINAÇÕES E EXPLORAÇÕES IMPOSTAS PELO SISTEMA MODERNO-COLONIAL AOS POVOS INDÍGENAS DO MATO GROSSO NO SÉCULO XIX

\section{MARIA ESTER DE SIQUEIRA ROSIN SARTORI DOUTORA EM HISTÓRIA CULTURAL}

Universidade Estadual de Campinas (UNICAMP)

O efeito da dominação se expõe com mais clareza nas relações, atuais, entre indígenas e não indígenas e no esforço para garantir e legitimar as diferenças. Ao mesmo tempo, denuncia o quanto as constantes intervenções culturais, territoriais e físicas contra povos indígenas são históricas, políticas e socialmente construídas. Sendo assim, a produção de discursos e práticas cujas estratégias passam pela tentativa de deslegitimar e submeter esses povos ao modelo não indígena é, hoje, amplamente utilizada e remete às teorias raciais, biológicas e religiosas que foram difundidas pelo mundo europeu por séculos.

A respeito disso, para garantir tanto a opressão quanto as diferenças no mundo colonizado, entre as práticas recorrentes, a adoção seguida pelo batismo popularizou-se como medida utilizada pela aristocracia política e religiosa na Região do Mato Grosso ao longo do século XIX. Assim, adoção e dominação podem ser pensadas como parte de um jogo de espelhos que reflete a intencionalidade do poder.

Para este artigo, esses dois movimentos, adoção e batismo, serão apresentados a partir da história de Cibaé Modojebá (Rosa Bororo), uma mulher indígena Bororo que foi violentamente capturada pela ação dita "Pacificadora" promovida pelo alferes Antônio José Duarte, no ano de 1880, em Mato Grosso.

Cibaé Modojebá foi sequestrada para que servisse como intérprete e mediadora entre os poderes aristocrático e militar do Mato Grosso e a comunidade Bororo a qual pertencia. A proposta de Pacificação ocorreu ao longo do século XIX e designou várias campanhas e incursões pelo interior do território do Mato Grosso. O propósito era organizar os aldeamentos; verdadeiras colônias militares que se beneficiavam do discurso da "Pacificação"101 e que tiveram funções bem específicas, tanto em relação à ocupação

\footnotetext{
101 O controle pela delimitação espacial, ou seja, a criação de fronteiras por meio dos aldeamentos, que separavam índios de não índios em nome da "Pacificação", foi uma estratégia importante na gestão dos conflitos. Mas, a criação de medidas que garantissem a confiança e o bom convívio entre índios e não índios, como o apadrinhamento e a adoção, tiveram igual importância.
} 
espacial quanto à cristianização, domesticação e adequação dos ditos "selvagens" à sociedade civilizada por meio das missões indígenas.

Antes, porém, há de se ter claro que, em muitos momentos, a adoção envolvia casos de retiradas arbitrárias e violentas de crianças e jovens indígenas de suas famílias por decisão de agentes e instituições que compunham a aristocracia política e administrativa do Mato Grosso, com apoio da base religiosa. Essas arbitrariedades eram apoiadas pela administração provincial, que buscava a modernização territorial, a segurança das elites produtivas, a delimitação e ocupação das fronteiras e a manutenção dos espaços conquistados. Desse modo, o sequestro de crianças indígenas para que fossem utilizadas como barganha, intérpretes ou escravas, impulsionava a adoção.

Crianças e jovens indígenas foram afastadas do convívio junto da comunidade e do grupo a que pertenciam para servirem ora como instrumento de acordos e trocas, ora como instrumento de observação e pesquisa. Esse último destino dado às crianças e jovens se consolidava com base na ideia equivocada de que indígenas, afastados de seus grupos e "domesticados", poderiam deixar de ser indígenas "selvagens" para se tornarem indivíduos "civilizados". Dessa forma, serviram aos interesses metropolitanos.

Ao analisar os registros de batismos na Paróquia Senhor Bom Jesus de Cuiabá, no período entre 1853 e 1890, nota-se o significativo aumento de crianças ilegítimas na região, cujos nascimentos não estavam diretamente relacionados à promiscuidade do sistema escravocrata - situação muito apregoada por Gilberto Freyre em Casa Grande e Senzala, 1933. Tratava-se de crianças geradas por mulheres livres em decorrência da passagem de tropeiros pela região, ou seja, nasciam em grupos bastante instáveis. Já que os tropeiros passavam duas vezes por ano na região, era de se considerar que a ilegitimidade fosse elevada. Devido à distância das vilas, raramente os tropeiros reconheciam a paternidade ou formavam qualquer tipo de relação familiar.

Além desses fatores, há de se considerar que a região do Mato Grosso, por ser fronteiriça, vivia outras especificidades em relação à formação social, decorrentes da itinerância que se constituía com o recrutamento da população para a defesa do território contra agentes externos. Com a Guerra na Tríplice Fronteira (1864-1870), essa situação sofreu maior adensamento em virtude do número de tropas enviadas à fronteira entre Mato Grosso e Paraguai. A ocupação militar refletiu, posteriormente, por volta dos anos de 1880 a 1884, no aumento do índice de batizados de ilegítimos, mostrando que a presença e a movimentação de militares na região contribuíram de forma significativa para a existência de filhos legitimados na região. Como estratégia política de povoamento e defesa territorial à Guerra da Tríplice Fronteira, os indígenas, que compunham as regiões fronteiriças do 
Mato Grosso, tornaram-se barreira delimitatória, na medida em que lutavam pela defesa de seus territórios.

\begin{tabular}{|c|c|c|}
\hline \multicolumn{3}{|c|}{$\begin{array}{l}\text { QUADRO II } \\
\text { Identidade dos batizandos da Paróquia Senhor Bom } \\
\text { Jesus de Cuiabá (1853-1890) }\end{array}$} \\
\hline Identificação & $\mathrm{N}^{\circ}$ absoluto & $\%$ \\
\hline Legítimos & 5.390 & 54,7 \\
\hline Naturais & 4.629 & 43,5 \\
\hline Legitimados & 25 & 0,3 \\
\hline Expostos & 73 & 0,7 \\
\hline Indígenas & 67 & 0,7 \\
\hline $\begin{array}{l}\text { Não consta o registro de identidade } \\
\text { e sim o ano de batismo }\end{array}$ & 16 & 0,1 \\
\hline TOTAL & 9.820 & 100,0 \\
\hline
\end{tabular}

Livro de Registro de Batizado 1888-. Identidade dos batizados Paróquia do Bom Jesus de Cuiabá. Arquivo da Cúria Metropolitana de Cuiabá (1853-1890). Fonte: Peraro, M. A. O Princípio das fronteiras e a fronteira dos princípios: Filhos ilegítimos em Cuiabá. Revista Brasileira de História, vol.19, n.38. p. 55-80. São Paulo 1899.

Pelo quadro acima, nota-se que a presença de ilegítimos no interior das famílias mato-grossenses não era algo incomum e fazia parte de uma lógica específica de interesses centrados em discursos civilizatórios - entendidos como processo de mudança estrutural das pessoas em uma determinada sociedade e período histórico -, sendo respaldados por políticas indigenistas adotadas entre 1845 e 1887 pelos presidentes da província de Mato Grosso.

Entre os vários propósitos dessas medidas, um dos intuitos era atender às necessidades da ocupação territorial exigidas pela Coroa, que via nos aldeamentos um projeto geoestratégico de ocupação e defesa de fronteiras. A essa perspectiva, somam-se os interesses dos colonos, no sentido de frearem os ataques às fazendas e manterem a mão de obra indígena como força produtiva. Dessa forma, o projeto de aldeamento dos grupos indígenas da região, que, a princípio, estava sob a administração dos grupos de missionários e, posteriormente, transferiu-se para os militares, findou nas mãos dos grandes proprietários, os quais pretendiam garantir seu domínio sobre as terras.

\section{Testemunho da Violência: Cibaé Modojebá, (Rosa Bororo)}

Dos costumes às resistências, até os acordos e as alianças entre grupos indígenas e colonos... Tudo dependia da compreensão do "outro" por meio da linguagem e, para isso, a alfabetização de crianças indígenas, o reconhecimento de seus hábitos e de seus costumes e a organização social dos grupos aos quais elas pertenciam precisavam ser 
codificados. Por isso, o sequestro de crianças indígenas e as adoções por interesses, como já dito, eram situações comuns que imprimiam diversos tipos de violências aos infantes.

Cibaé Modojebá é um exemplo da violenta investida contra os indígenas do Mato Grosso no século XIX. Ela foi aprisionada com suas duas filhas e entregue às autoridades locais para que fosse vacinada, alfabetizada e batizada - foi então que recebeu o nome luso-cristão de Cibaé Mondojebá. Como de costume, pessoas influentes que pertenciam aos setores políticos da província de Mato Grosso eram nomeadas como tutores dos indígenas para educá-los e prepará-los a fim de que fossem elementos de persuasão entre os indígenas de seu grupo.

Para Antônio José Duarte, essa estratégia tinha grande valor para o controle da região. Tanto era assim que, ao relatar o episódio da captura das mulheres e crianças indígenas, aconselhou o então Presidente da Província, José Joaquim Ramos Ferreira, a estabelecer a estratégia de aprisionamento daqueles indígenas que tivessem vínculos afetivos com parentes. Consta na Diretoria Geral de Índios.

[...] aprisionar um indígena, que tivesse filhos, e em seguida envia-lo de voltar para o aldeamento, deixando os filhos como reféns na cidade. Em troca da própria liberdade e dos seus, o índio deveria retornar ao aldeamento para realizar o contato com a tribo e realizar a catequese. ${ }^{1}$

A história de Cibaé Mondojebá foi publicada por Maria do Carmo de Mello Rego na Revista Brazileira, em 1895. Nessa revista, Maria do Carmo conta como ocorreu o aprisionamento da indígena Cibaé Mondojebá e a atuação dela como intérprete nos acordos entre os Bororo e o alferes Antônio José Duarte.

Em uma das muitas caçadas que se faziam de índios, foi ela, a pobrezinha, aprisionada por uma força expedicionária partida de Cuiabá. Recolhida, porém, por família respeitável da cidade, encontrou entre os perseguidores da sua raça um lar amigo, onde conquistou simpatia e recebeu carinhos; ela representante da tribo amaldiçoada dos Bororos Coroados. Quanto sinto não poder agora lembrar-me do nome indígena por que fora conhecido os seus. (REGO, 1895, p.p.193-194)

Cibaé Modojebá pertencia à comunidade Bororo Coroado e foi entregue junto com sua filha aos cuidados de pessoas influentes da sociedade mato-grossense, D. Clara de Miranda Rodrigues, esposa do major Antônio Thomaz de Miranda Rodrigues, para que fosse "domesticada" e educada. Após o período em que esteve em contato com a família Rodrigues e depois de ter aprendido os costumes e a linguagem esperada para o acordo, foi levada de volta ao seu povo como mediadora nas conversas entre os Bororo Coroado 
do Mato Grosso e o grupo militar expedicionário do alferes Antônio José Duarte. O propósito era promover a "Pacificação" dos Bororo.

Organizada a nova expedição, lá se foi a pobre da índia transfigurada ao sorver em liberdade o ar perfumado dos bosques e capões, tão seus conhecimentos [...] Cibaé radiante de felicidade, por ver terminada a cruel guerra de perseguição e extermínio feita aos seus, tornou a vestir as roupas que deixara e lá ficou prestando relevantíssimo serviços, na primeira troca das novas relações, de que fora abençoada mensageira. (REGO, 1897, p.73-74)

A condição de liberdade enunciada por Maria do Carmo, como antônimo de cativeiro ou servidão, e a forma como ela descreve as sensações de Cibaé ao entrar em contato com os bosques mostram o quanto as crianças indígenas, em nome da adoção, estavam sujeitas a diferentes graus de violência e a diferentes maneiras de incorporação ou utilização na sociedade aristocrática mato-grossense. Da mesma forma, Maria do Carmo, ao atribuir à índia Cibaé todos os créditos pela aproximação com os Bororo, reafirma a importância da estratégia de sequestro proposta pelo alferes Antônio Duarte. Cibaé foi fundamental como intérprete e pivô das negociações porque falava as duas línguas, 0 português que aprendeu com a família Miranda Rodrigues e o Boé Wadáru enquadrada, atualmente, no tronco linguístico Macro-Jê. Cibaé Bororo faleceu em 1912 às margens do Rio Paranatinga,

[...] esquecida e abandonada, tendo apenas a curtir a saudade dos dias vitoriosos, balbuciando o nome da filha que tanto amara, sucumbindo nos braços do único filho, de nome José, a quem nos momentos derradeiros fazia essa recomendação: -"Nunca confie em brancos, estes só agradam quando precisam" (MENDONÇA, 1919, p.p.58-59).

Por fim, considerados índios bravios, os Bororo Coroados foram incluídos na política indigenista de aldeamento, em vigor a partir da descentralização política promovida pelo Ato Adicional de 1834 (que dava autonomia aos legislativos provinciais em relação à política indigenista). O Ato Adicional explica que a estrutura administrativa e a legislativa transferiram a problemática da catequese e a responsabilidade civilizatória dos grupos indígenas para as províncias e suas respectivas Assembleias Legislativas.

O teor dessa orientação veio ao encontro da política de fronteiras do Mato Grosso, que tinha como um dos anseios utilizar os índios fronteiriços (principalmente aqueles alocados nos limites entre Paraguai e Bolívia) como grupos de defesa, além da possibilidade de povoamento e desenvolvimento territorial. Mediante o Ato de 1834, a 
política de aldeamento encontrou perspectivas favoráveis para sua efetivação na medida em que inseria não só os índios bravios nessa prospecção, mas também índios considerados "mansos" ou domesticados.

Com a história de Cibaé, nota-se que o valor da criança indígena estava localizado na capacidade e no uso de suas habilidades como intérprete. Isso mostra que a relação estabelecida entre a indígena Cibaé e a família que a tinha sob guarda era uma imposição do sistema proposto pela Diretoria Geral dos Índios, que viu, na persuasão intermediada por indígenas de mesmo grupo étnico, a saída para o contato e a continuidade do processo civilizatório e de ocupação territorial.

Cibaé não foi um fato isolado, pois são vários os relatos e registros de crianças indígenas que passaram pelo processo de adoção, não apenas no Mato Grosso, mas, também, em outras regiões do Brasil do século XIX. Existem, por exemplo, registros de crianças indígenas que foram adotadas por grupos de missionários protestantes na Amazônia, entre os Apurinã e o Rio Purus, cujo objetivo era a educação e proliferação dos princípios protestantes. Existem, ainda, registros de crianças indígenas que foram adotadas, ilegalmente, como força de trabalho escrava, tanto para os afazeres domésticos quanto para extração mineral ou de trabalhos diversos nas ruas e no comércio de Mato Grosso.

\begin{abstract}
Algumas crianças figuraram como "criadas de servir" de seus padrinhos e/ou tutores. Outras crianças deslocavam-se com suas famílias para a cidade, na medida em que os aldeamentos onde viviam eram desfeitos ou para manterem relações comerciais com os não-índios, passando a viver misturadas à população urbana, aproximando-se mais ao modo de vida da gente pobre. Outras foram mantidas como reféns para que seus pais ou parentes se propusessem servir de intérpretes em expedições e agentes da catequese. Alguns meninos foram internados na escola de aprendizes artífices do Arsenal de Guerra, no intuito de servirem como braços para o progresso da província e se afastassem da "vadiagem" das ruas. Outros chegaram a ser matriculados em escolas públicas primária. (PERARO, 1999, p.12)
\end{abstract}

Com a recorrente estratégia de sequestro e posterior aculturação dos indígenas sugerida por Antônio José Duarte, em agosto de 1886, já era grande o número de índias intérpretes que atuavam como mediadoras entre os grupos indígenas Bororo e o grupo dito "pacificador". Nesse mesmo período, as capturas de indígenas alcançaram seu ponto mais elevado em Mato Grosso, sendo trazidos para Cuiabá em torno de 416 indígenas destinados à região de Couto Magalhães. Segundo Antônio José Duarte, a escolha desse lugar era importante para o grupo porque a necessidade de recursos era grande "[...] e para 
esse fim aponto o acampamento Couto Magalhães, lugar muito próprio, perto da água e do peixe, que é o principal elemento de vida dos selvagens".

Para as crianças indígenas dessa região, a integração foi uma forma de aproximação entre dois mundos; e a adoção, o violento instrumento mediador e facilitador de inserção de Duarte no mundo indígena. A custosa relação de forças que as retirou do mundo a que pertenciam para adequá-las a um outro cujas regras não conheciam tornou-as impossibilitadas de reação e, por fim, acabou submetendo-as. Ao serem adotadas pelos grupos dominantes, as crianças indígenas deixavam seus grupos sociais sem neles se realizarem como indivíduos e eram integradas em outro grupo com muitos valores, realidades e padrões distantes dos seus, sem, contudo, realizarem-se neste também.

Em Mato Grosso, um dia, sendo meu marido presidente da província, trouxe o capitão Antonio José Duarte, pacificador da tribo dos Bororos, uma turma de índios para serem batizados, e deles fomos padrinhos. Vinham dois caciques, e dei-Ihes os nomes do meu marido, Francisco e Raphael. Fiz-lhes quantos agrados pude e presenteei-os largamente [...] a um desses caciques, chamado no idioma indígena Boraiaga e a quem coube o nome cristão de Raphael, pedi, já por intervenção do interprete, já auxiliada por um vocabulariozinho, [...] que me mandasse um indiozinho órfão de pais, mas com o cabelo comprido. Eu o criaria como filho. Um mês depois, no dia 12 de junho de 1888, entregava-me o capitão Duarte um indiozinho, vestidinho com uma camisinha de chita e umas calcinhas azuis. Tinha os cabelos compridos (REGO, 1895, p.10)

Entre os vários grupos étnicos que conviviam no território de Mato Grosso, foram os Bororo Coroados os que mais ofereceram resistência ao contato. Esse grupo habitava um vasto território e foi por volta da segunda metade do século XIX que as expedições ditas de "Pacificação" se movimentaram para conter e imprimir o poder sobre os grupos de indígenas do Mato Grosso. Entre 1880 e 1886, os ataques promovidos pelos Governos Provinciais aos Coroados tornaram-se cada vez mais efetivos e marcados pela intensa utilização de armas de fogo, além das desavenças entre grupos indígenas inimigos.

Coube ao alferes Antônio José Duarte, novamente, promover a criação e o controle dos aldeamentos indígenas pelo interior do Mato Grosso. Com atuação em grande parte entre os Bororo, Duarte articulou recorrentes expedições "Pacificadoras", embora com caráter mais punitivo do que organizacional ou mediador. Contudo, a despeito da maneira violenta com que oferecia seus serviços, no exercício de suas funções, sua forma de atuação era bem vista pelas classes dirigentes.

O Senhor Alferes Duarte, inteligente, zeloso, probo, honesto e honrado, deixa com efeito o seu nome bem quisto entre os seus companheiros e uma saudade indelével gravada boa memória d'aquele que como chefe sou o 
primeiro a tributar-lhe um sincero abraço como significação da viva estima, respeito e acatamento que lhe resta. (DUARTE, 1887)

Ao que se percebe, essas ações objetivavam cumprir partes de planos muito maiores na ordem do desenvolvimento das Nações. Elas caminhavam no sentido da construção de um projeto Político Nacional que se disseminou pelos princípios da catequese, ordem, modernização e produção, e, para isso, precisavam retirar as amarras do desenvolvimento, ou seja, os indígenas.

Depois de dois meses e alguns dias no alto sertão e em desempenho da mais importante e espinhosa missão, que de certos anos e nossa época muito tem ocupado o espírito público a atenção dos governos geral e provincial para que se torna uma realidade, aqui chegou a 16 do corrente, pelas dez horas da manhã [...] o energético e inteligente Snr. Antônio José Duarte à frente da expedição sob seu comando e das índias emissárias enviadas desta capital ao aldeamento dos coroados, trazendo mais de 28 da mesma tribo, que, aceitando o convite das ditas emissárias para deixarem a vida selvagem, abandonaram os seus lares e aqui vieram ter [...] Além destes vindos, consta-nos estar dispostos a abraçar a civilização, grande número dos mesmos índios, que por exiguidade de transporte fluvial até a Colônia S. Lourenço, d'onde pode viajar por terra até esta capital, lá ficaram seus aldeamentos a espera de meios para serem trazidos [...] Facto como este é assaz importante e de alto interesse à catequese, à lavoura e a civilização, que todos os louvores e são poucos aos que levaram a pratica com o mais feliz êxito! (A Tribuna de Cuiabá, 24 de junho, 1866, n. 3. p. 2.)

Expedições que atendiam à política expansionista do Estado configuravam-se no sentido de capturar e subjugar indígenas para explorá-los conforme a lógica de trabalho e defesa territorial imposta pelo mundo colonial e, por serem tão invasivas, deflagravam guerras constantes entre grupos indígenas e colonos.

Essa situação agravava as crises interétnicas na região e com isso os conflitos se tornaram formas de resistência para os grupos indígenas, como as Correrias ${ }^{102}$. Ao mesmo tempo, reafirmavam a ideia pré-concebida do nativo hostil, "incivilizado" e provocador que, por relutância aos valores morais de integração social, promoviam seus ataques, "suas Correrias", imprimindo o caos e a barbárie ao "civilizado". Entre outras, foram essas ações que justificaram o uso de atos de violência contra os indígenas.

\footnotetext{
102 Forma de resistência adotada por grupos de indígenas que viviam sob a pressão do projeto provincial de ocupação do território no Mato Grosso novecentista. As Correrias promoviam ataques aos lugarejos e cidades próximas aos territórios indígenas que atuavam roubando as casas e as plantações dos colonos chegando, em alguns casos, a cometer assassinatos. Com isso, muitos colonos abandonavam suas terras. Em contrapartida, as correrias desmistificam a ideia de aceitação do processo de "Pacificação" imposto pela administração provincial.
} 
Sendo assim, as formas de agenciamento e resistência utilizadas por muitos grupos indígenas subalternizados pelos processos de colonização são importantes meios de análises historiográficas e etnográficas, sobretudo porque nos ajudam a compreender tanto a complexidade dos conflitos étnicos, socias, culturais e territoriais impostos no contexto das conquistas coloniais e da formação do Estado-Nacional, quanto as formas de agenciamento indígena no que se refere ao propósito de assegurar a permanência e a individualidade dos grupos, ou seja, garantir a diferenciação dentro de um jogo político que Ihes permitissem espaços de negociação para a manutenção do grupo (CORRÊA FILHO, 1946).

O protagonismo nas Correrias tinha como objetivo identificar atores para a resistência, com a finalidade de preservar sua etnia. Maria Regina Almeida (2003) interpreta como uma forma de redimensionar a consciência desses indígenas - principalmente dos chefes das etnias - como sujeitos de suas ações em defesa dos próprios interesses no contexto da conquista "civilizatória".

Por causa disso, e por causa da situação a que isso levou, agora se torna possível reinterpretar o arquivo cultural ocidental como se fosse geograficamente fraturado pela divisão imperial ativada, e proceder a um tipo diferente de leitura e interpretação. (SAID, 1995, p.86)

Embora não seja novidade, é importante destacar que as discussões em relação aos grupos indígenas e seus papeis na sociedade brasileira do século XIX afirmavam-se em meio a opiniões divergentes. Se, no plano ideológico, os intelectuais do século XIX buscavam a imagem idealizada de índio a ponto de promovê-los a símbolo nacional, conservando a ideia do bom "selvagem" conferida ao índio no passado e que ainda prevalecia sobre a do índio real, por outro lado, ou seja, dos grandes proprietários de terras e parte dos setores políticos, eles eram considerados o entrave nacional, pois ocupavam terras, lutavam para conservar suas aldeias e famílias, recusavam-se ao trabalho forçado e podiam ser violentos em defesa do território, a ponto de ameaçarem a vida dos colonos e o desenvolvimento econômico do Estado. Isso refletia na dificuldade dos fazendeiros e da elite do Mato Grosso de aceitarem a imagem do índio como símbolo nacional.

Dadas as circunstâncias, não é difícil imaginar que grande parte dos grupos indígenas não se reconhecia na cena do bom "selvagem" e reagia contra a dominação e a ocupação de seus territórios. Ainda que em pequeno número, haviam setores que entendiam que, para os Bororo, a defesa do território estava totalmente ligada à sua sobrevivência e conseguiam compreender que por ser este grupo "[...] dono legítimo e secular das terras, necessita delas para a sua vida nômade: caça, pesca e colheita; o não 
índio criador de gado bovino, invade o terreno; o índio espanta o gado; mata e come as rezes; o não índio reage e mata o invasor" (DUROURE, 1997, p. 199). Em uma relação reativa construída no enfrentamento pelo domínio do espaço, qualquer tentativa de inserção das comunidades indígenas na sociedade civil mato-grossense incorria em discórdias e divergências que colocavam os Bororo (e os indígenas em geral) em oposição. Vistos como inimigos e agressores, por estarem fora da lógica civil, esses grupos precisavam ser combatidos como inimigos.

O olhar unilateral, que só reconhecia a crueldade no outro, promovia repreensões constantes aos indígenas, todas elas justificadas pela necessidade de manter a ordem e de combater o estado de grande desconforto e desordem gerados pela condição de "incivilidade natural" pela qual as aristocracias rurais se diziam ameaçadas. À medida que as comunidades indígenas reagiam contra as imposições e adequação aos padrões "civilizatórios", mais justificava-se a violência contra eles e suas culturas, o que levou ao extermínio e à aculturação de muitos grupos. Procedimentos, perfeitamente, arquitetados pelo poder colonizador, ora amparados pela ideia estereotipada de "inépcia" a que indígenas estavam sujeitos, ora pelos comportamentos reativos com o qual eles se defendiam. Essa perspectiva definiu um conceito, colonialidade, e uma nova partição, racial.

Na América, a ideia de raça foi uma maneira de outorgar legitimidade às relações de dominação impostas pela conquista. A posterior constituição da Europa como nova id-entidade depois da América e a expansão do colonialismo europeu ao resto do mundo conduziram à elaboração da perspectiva eurocêntrica do conhecimento e com ela à elaboração teórica da ideia de raça como naturalização dessas relações coloniais de dominação entre europeus e não-europeus. (QUIJANO, 2000, p.118)

Na perspectiva da colonialidade do poder proposta por Quijano (2000), a relação do Estado com o espólio e o extermínio dos grupos considerados "inferiores" pelo homem não indígena legitimava a hierarquização das forças promovida pelo discurso científico do domínio natural. Esse domínio poderia acontecer não só pela força das armas, mas também pela persuasão, pelo aliciamento, pela adoção e pelo batismo - as primeiras das muitas iniciativas de inserção de crianças indígenas no mundo "civilizado" cristão.

A colonialidade utilizada como estratégia de controle e desqualificação do "outro" reafirmava as narrativas homogeneizantes produzidas pelos colonizadores, que operavam no sentido de proliferar o olhar eurocêntrico de dominação e representavam os indígenas como indivíduos capazes de serem "adestrados" e adaptados aos modelos civilizatórios e produtivos a serviço das aristocracias e do poder político. 
Se funda na imposição de uma classificação racial/étnica da população do mundo como pedra angular daquele padrão de poder, e opera em cada um dos planos, âmbitos e dimensões, materiais e subjetivas, da existência cotidiana e da escala social. (QUIJANO, 2009, p. 73).

São práticas que revelam o quanto certas estruturas de "longa duração" necessitam de descrições mais densas, como coloca Clifford Geertz (2008), para dar conta de explicar os sentidos imbricados em cada problema histórico, principalmente, quando o objeto de estudo "[...]são as classes populares, os grupos oprimidos, os derrotados nas diferentes batalhas históricas, e todas as vítimas dos processos históricos em geral, cuja História tem sido amiúde silenciada, omitida, marginalizada, oprimida, ou mesmo eliminada e apagada." (ROJAS, 2012, p.11).

Discursos que reverberam, atualmente, nos processos de ocupação dos territórios indígenas, mas que se rementem à imposição civilizatória impressa pelo "homem branco" europeu e cristão aos povos conquistados, no sentido de garantir que a partição do mundo permanecesse "[...]sustentada na premissa de que havia uma humanidade esclarecida que precisava ir ao encontro da humanidade obscurecida, trazendo-a para essa luz incrível." (KRENAK, 2019, p.28). Ou seja, como discurso dominante, reproduz a imagem da dizimação de muitos povos indígenas como algo inevitável e natural devido à esperada natureza "selvagem" desses grupos ao resistirem ao modelo "civilizado" de existência. Porém, como bem adverte Ailton Krenaque,

[...]deixamos de ser colônia para constituir o Estado brasileiro e entramos no século XXI, quando a maior parte das previsões apostava que as populações indígenas não sobreviriam à ocupação do território, pelo menos não mantendo formas próprias de organização, capazes de gerir suas vidas [...]. O dilema político que ficou para as nossas comunidades que sobreviveram ao século XV é ainda hoje precisar disputar os últimos redutos onde a natureza é próspera, onde podemos suprir as nossas necessidades alimentares e de moradia, e onde sobrevivem os modos que cada uma dessas pequenas sociedades tem de se manter no tempo, dando conta de si mesmas sem criar uma dependência excessiva do Estado. (KRENAK, op. cit., p. 31)

O olhar distorcido em relação aos grupos indígenas - que tenta legitimar e reforçar a concepção de que são eles o "outro", o "avesso" e aqueles que não querem ou não conseguem adaptar-se às regras do modelo social estabelecido como certo - é constituinte da mentalidade de parte da população brasileira que insiste em renunciar a 
seus habitantes originais, revitalizando práticas desumanas no intuito de tomar para si seus territórios, alterar o modo de vida desses grupos, suas crenças, seu cotidiano e todos os princípios que envolvem a relação desses diversos grupos com a Terra. Uma verdadeira violência simbólica que se apoia nas artimanhas do discurso classificatório dominante ao determinar quem é ou não é "civilizado".

Isso diz respeito aos momentos de tensões profundas e estruturais que, desde o Período Colonial no Brasil, buscavam deslegitimar o papel dos povos indígenas do controle de suas Terras, na construção de sua história, suas resistências e na preservação de suas culturas.

Nosso tempo é especialista em criar ausências: do sentido de viver em sociedade, do próprio sentido da experiência da vida. Isso gera uma intolerância muito grande com relação com quem ainda é capaz de experimentar o prazer de estar vivo, de dançar, de cantar. E está cheio de pequenas constelações no mundo que dança, canta e faz chover. (KRENAK, 2019, p. 39)

A adequação dos indígenas era entendida como necessária para retirar a região do latente estado de "barbárie" a que estava associada e, ao mesmo tempo, cumpria com o papel humanitário e cristão da salvação. E se, para isso, o aliciamento cumpria seu papel articulador entre as comunidades nativas e o poder colonial, a tutela dessas comunidades caberia a ele e a seu grupo.

As teorias raciais, portanto, representavam uma transferência de responsabilidade para a natureza dos problemas sociais. Desta forma os negros, índios e mestiços foram transformados em bárbaros, inferiores, um obstáculo ao desenvolvimento e ao progresso. (BECCHELLI, 2017, p.2)

Contudo, para muitos, nem a catequização, nem a adoção, nem a alfabetização, na época, poderiam amenizar o olhar de "inferioridade" e a classificação hierárquica a que estavam submetidos os grupos de indígenas do Mato Grosso, já que, pela perspectiva evolucionista, sendo o "homem branco o racional", cabia a ele organizar e catalogar, inclusive, no contexto da própria espécie humana, aqueles que são mais ou menos racionais e civilizados. Reféns de uma sociedade que "enxerga-os como ancestrais primitivos vivendo num passado remoto que encerra a sua própria percepção de presente" (GALETTI, 2012, p.125), os grupos de indígenas que viviam no Mato Grosso estavam reduzidos, a princípio, pela ação de duas forças: a imposição política e aristocrática, que os oprimia pela ação violenta e pela tentativa de extermínio, e a imposição religiosa, que 
não deixava de ser violenta e os oprimia pela catequização. A adoção acomodava-se em ambos os casos.

À vista disso, no que se refere aos processos civilizatórios, se a catequese e a alfabetização tiveram papel primordial no processo de ocupação do território, a adoção seja por meio de apadrinhamentos, seja pela afiliação - cumpria igualmente um papel importante e não se constituiu

[...] apenas uma instituição muita conhecida da sociedade brasileira, mas também um instrumento importante para a análise sociológica. Trata-se de um conjunto de operações sociais pelas quais uma pessoa vem a ser incorporada em outro grupo social que não aquele ao qual pertence em virtude de seu nascimento. Refere-se assim aos procedimentos pelos quais uma pessoa pode ser realocada de uma posição quase natural para outra, entendendo-se por natural aqui o que resultaria do funcionamento das regras de descendência hegemônicas no contexto social considerado. (OLIVEIRA, 2007, p.77)

Oliveira aponta ainda que a adoção se torna uma metáfora para pensar o "encontro colonial" em suas dimensões mais individualizadas e cotidianas, pois refere-se aos procedimentos pelos quais pessoas de uma sociedade e cultura são incorporadas de modo a capitular frente às instituições e grupos de outra sociedade e cultura, produzindo hábitos considerados adequados por meio de ações corretivas para contenção das comunidades dominadas.

Por ironia, ações justificadas pelo discurso da inserção, ou seja, pela lógica da integração social e racial, tiveram como princípio as imposições civilizatórias aos grupos indígenas, mediante o modelo cultural ocidental, branco e cristão. E foi dessa forma, partindo da caracterização do nativo como "selvagem", que os colonos forjaram o oposto, o ser civilizado, e, ao se diferenciarem dos nativos, permitiram-se o domínio e a domesticação.

Nesse tipo de sociedade classificatória, em termos de mestiçagem, reafirmava-se o olhar de superioridade em relação aos indígenas e essa mesma percepção do "outro" estendia-se aos negros, aos gaúchos, aos sertanejos, aos caboclos e mulatos. Tal postura remete às teorias "raciológicas" novecentistas que serviram para discutir o futuro do país no que se refere à construção social brasileira, determinando, hierarquicamente, a diferença social entre eles: as comunidades "mestiças" e as classes dominantes.

Portanto, no que se refere ao pensamento dominante colonizador, a questão étnica surge como questão fundante na diferenciação nacional; como fator científico, em alguns casos - apesar de haver aceitação das desigualdades de raça -, e, em outros, como fator 
degenerativo no processo de formação nacional. Em ambos os casos, não se apregoava a relação idílica entre as multiplicidades étnicas, mas a mestiçagem, como um processo evolutivo em que a influência branca europeia predominaria promovendo o branqueamento da raça.

O mestiço é a condição desta vitória do branco, fortificando-Ihe o sangue para habituá-lo aos rigores do clima, o resultado será a formação de um mestiço brasileiro, igual no aspecto ao branco europeu. Não deve aí haver vencidos e vencedores, o mestiço congraçou as raças e a vitória deve assim ser de todas três. Pela lei de adaptação, elas (raças) tendem a modificar-se nele. (ROMERO, 2001, p.63)

A adoção, nesse sentido, seguida pelo batismo tonou-se uma questão de Estado e variou tanto na esfera política quanto na religiosa; porém, para alguns, batizar era uma questão de consciência e, para outros, uma estratégica de dominação e conquista territorial. Dessa forma, os planos para a catequese, associados à ideia de civilização como ato humanitário, justificavam as violentas investidas contra os territórios indígenas do Mato Grosso sob o lema da "Pacificação"; todo esse processo não se deu sem rupturas e conflitos.

Com isso, percebe-se a necessidade de posicionamentos críticos em relação aos discursos que tentam validar a supremacia do "homem branco" - ainda que, em alguns casos, justificados aos "mitos" do século XIX - para explicar a superioridade racial. A própria ascendência e a expressividade de grupos sociais, antes silenciados pela História, ganharam espaço e têm mostrado que a História, além de se dedicar aos fragmentos do passado, fixa seu olhar sobre o presente buscando sentidos, ouvindo vozes, observando imagens e pistas que marcam nossa atualidade. Sobretudo, abre caminhos para maior exercício da interdisciplinaridade por meio do diálogo com a linguística, a antropologia, a literatura, a semiótica e outras áreas do conhecimento.

O trabalho do Grupo de Estudos Subalternos, uma organização interdisciplinar de intelectuais sul-asiáticos dirigida por Ranajit Guha, inspirou-nos a fundar um projeto semelhante dedicado ao estudo do subalterno na América Latina. $\mathrm{O}$ atual desmantelamento dos regimes autoritários na América Latina, o final do comunismo e o consequente deslocamento dos projetos revolucionários, os processos de democratização, as novas dinâmicas criadas pelo efeito dos meios de comunicação de massa e a nova ordem econômica transnacional: todos esses são processos que convidam a buscar novas formas de pensar e de atuar politicamente. Por sua vez, a mudança na redefinição das esferas política e cultural na América Latina durante os anos recentes levou a vários intelectuais da região a revisar epistemologias previamente estabelecidas nas ciências sociais e 
humanidades. A tendência geral para uma democratização outorga prioridade a uma reconceitualização do pluralismo e das condições de subalternidade no interior das sociedades plurais (Grupo Latinoamericano de Estudios Subalternos, 1998, p. 70)

Sendo assim, a partir de "novas" categorias epistemológicas, entre elas, os estudos decoloniais, a possiblidade de repensar a ocupação e a exploração da Terra surgem propondo intervenções teóricas em relação às categorias ditas "subalternas" e permitem reinterpretar e desnaturalizar as retóricas essencialistas e totalizantes impostas pelo modelo colonial moderno. As mesmas retóricas que imprimiram aos povos indígenas, e ainda hoje imprimem com requintes de crueldade, o silenciamento, a fatalidade da inevitável extinção, o discurso da indolência e da "natural selvageria". Com esses estudos, as formas contemporâneas de violência racial, que têm em mira os corpos e as Terras indígenas, suas práticas e seus saberes, passaram a ser percebidas como simbólicas e estruturais e estão estampadas em grande parte dos materiais didáticos e nos meios de comunicação, revelando um tipo específico de "racismo institucional" que promove e reproduz a diferença e a hierarquia social.

O racismo contra os povos indígenas se expressa tanto por meio de ações de pessoas e grupos, quanto pela omissão do Estado frente às violências praticadas e às reivindicações destes povos para que seus direitos constitucionais sejam respeitados. A violência não decorre da inexistência de mecanismos legais, mas da falta de efetividade destes, agravada imensamente pela inoperância do governo no que tange às demarcações das terras indígenas (BONIN, 2015, p.41).

Portanto, no que se refere às medidas legais na adoção de crianças indígenas, é exigido que elas sejam adotadas dentro de suas próprias comunidades a fim de se evitar a perda da identidade e dos laços culturais com seus povos ancestrais. Nesse sentido, tornam-se "obrigatórios" e fundamentais os respeitos tanto à identidade social e cultural da criança quanto a costumes e tradições individuais. Essa lei, sancionada em 03 de agosto de 2009 pela Nova Lei de Adoção (art. 28, parágrafo 6 do ECA), salienta que,

a) respeito aos seus costumes e tradições: o vínculo afetivo entre criança indígena é muito forte. Os valores culturais, os costumes e hábitos fazem parte de sua personalidade, fato esse que não pode ser ignorado; b) que a colocação seja feita, de preferência, a membros da mesma etnia: deve haver a preocupação da manutenção da criança ou adolescente junto à sua tribo ou comunidade; c) intervenção e oitiva de representantes da FUNAI- Fundação Nacional do Índio, no caso de indígenas, e de antropólogos, no caso de criança ou adolescente proveniente de comunidade remanescente de quilombo.(ROSSATO, 2009). 
Isso não faz, necessariamente, com que os direitos das crianças indígenas estejam, integralmente, respeitados. Outrossim, independente das legislações que atuam em defesa das crianças e dos adolescentes indígenas, como o Estatuto da Criança e do Adolescente (ECA), a Constituição Federal de 1988 (CF/88) e o Estatuto do Índio, os vínculos com as diversidades étnicas, raciais e de classe, em relação a elas, são muito tênues (Fonseca, 2004; Schuch, 2009), o que incorre em certa universalização no trato a esses grupos e no desrespeito aos saberes ancestrais e relações com os usos da Terra. Portanto, se, atualmente, na adoção de crianças indígenas, existe a preocupação de garantir a identidade e os laços culturais com seus povos ancestrais, na prática, grande parte delas sofre dupla violência, por serem crianças e por serem indígenas em um contexto que não as compreendem na sua individualidade e na coletividade.

As atrocidades praticadas aos povos indígenas geradas pelo desrespeito às Leis de uso da Terra indígena, que suprime deles o acesso às formas fundamentais de sobrevivência, imputando a destruição e a negação dos saberes ancestrais e a imposição dos conhecimentos do "homem branco" como saberes verdadeiros e universais, nos remetem à outra questão de extrema importância: o reconhecimento da coletividade desses grupos como povos indígenas, sem o qual é retirada deles a possibilidade do exercício da cidadania. Sem esse reconhecimento, a luta por direitos sociais, usos da Terra, participação política e livre exercício de suas manifestações culturais deixam de ser um direito para figurarem como permissão.

[...]corresponsabilidade com os lugares em que vivemos e o respeito pelo direito a vida dos seres, e não só dessa abstração que nos permitimos constituir como uma humanidade, que exclui todas as outras e todos os outros seres. Essa humanidade que não reconhece que aquele rio que está em coma é também nosso avô, que a montanha explorada em algum lugar da África ou da América do Sul e transformada em mercadoria em algum outro lugar é também o avô, a avó, a mãe, o irmão de alguma constelação de seres que querem continuar compartilhando a vida nesta casa comum que chamamos Terra. (KRENAK, 2019, p. 25)

No momento em que isso acontece, encontramos apenas uma troca na nomenclatura espacial. Ou seja, o que antes recebia o nome de "Pacificação" em forma de aldeamentos, hoje, recebe o nome de preservação e se constitui por meio de reservas. No fundo, ambos os modos produzem os mesmos contextos: segregação étnica, exclusão social e violência. Realidades que foram consolidando-se ao longo do tempo em meio à 
diversidade do mundo, sondando as permanências e repetições da história, as constâncias e os constrangimentos da vida social.

\section{Bibliografia}

A Tribuna de Cuiabá, 24 de junho, 1866, n. 3. p. 2. Núcleo de Documentação e Informação Histórico Regional - NDIHR. Universidade Federal de Mato Grosso. www.ufmt.br/ndihr/revista. Acessado em: 08/10/2016.

ALMEIDA, M. R. Metamorfoses indígenas: identidade e cultura nas aldeias coloniais do Rio de Janeiro. Rio de Janeiro: Arquivo Nacional, 2003.

ALMEIDA, M. R. Metamorfoses indígenas: identidade e cultura nas aldeias coloniais do Rio de Janeiro. Rio de Janeiro: Arquivo Nacional, 2003.

BONIN, lara. Racismo: desejo de exterminar os povos e omissão em fazer valer seus direiros. In: CIMI. Relatório: Violência contra os povos indígenas no Brasil. Dados 2014. Brasília: Cimi, 2015.

BRAUDEL, Fernand. História e Ciências Sociais. A longa duração. Escritos sobre a História. Tradução por J. Guinsburg e Tereza Cristina Silveira da Mota. São Paulo: Perspectiva, 1992.

CORRÊA FILHO, V. Pantanais Mato-grossenses: devassamento e ocupação. Rio de Janeiro: Serviço Gráfico do Instituto Brasileiro de Geografia e Estatística, v.3, Série Livros, 1946. (Biblioteca do Instituto Histórico e Geográfico Brasileiro). São vários exemplos dessa prática, desde incêndios dos lugarejos que foram construídos para os grupos indígenas nas cidades e nas proximidades de seus territórios, até mortes, desmistificando a ideia de aceitação do processo de "Pacificação".

DUARTE, 1887. Fé de José Antônio Duarte. Comando do 21 Batalhão de Infantaria. No 235:08 - AHEx- Arquivo Histórico do Exército.

DUROURE, J. B. Dom Bosco em Mato Grosso. Campo Grande: Missão Salesiana de Mato Grosso, v. I (18941904), 1977.

GALETTI, L. da S. G. Sertão, fronteira, Brasil: imagens do Mato Grosso no mapa da civilização. Cuiabá: EDUFMT/Entrelinhas, 2012.

GEERTZ, Clifford. A interpretação das culturas. Rio de Janeiro: LTC, 2008.

KRENAK, A. Ideias para adiar o fim do mundo. São Paulo: Companhia das Letras, 2019.

LEPETIT, B. Espace et histoire: hommage à Fernad Braudel. In: Annales: economies, societies, civilisations, Paris n. 6, nov-dec., 1986.

LEPETIT, B. Espace et histoire: hommage à Fernad Braudel. In: Annales: economies, societies, civilisations, Paris n. 6, nov-dec., 1986.

MENDONÇA, Estevam. Datas Mato-Grossenses. Mato Grosso do Sul: APMT, 1919. 
OLIVEIRA, J. P. de. O retrato de um menino Bororo: narrativas sobre o destino dos índios e o horizonte político dos museus, séculos XIX e XXI. Tempo, v.12, n.23, p.73-99, 2007. Disponível em: <www.scielo.br/pdf/tem/v12n23/v12n23a06.pdf. Acesso em: 03/2011.

PERARO, M. A. O princípio das fronteiras e a fronteira dos princípios: filhos ilegítimos em Cuiabá no século XIX. In. Revista Brasileira de História, São Paulo: ANPUH, v.19, n.39, 1999.

QUIJANO, A. Colonialidad del poder, eurocentrismo y América Latina. In: La colonialidad del saber: eurocentrismo e ciencias sociales. Perspectivas Latinoamericanas. LANDER, E. (Org.). Buenos Aires: CLACSO - Consejo Latinoamericano de Ciencias Sociales, jul./2000.

REGO, M. do C. M. Guido: páginas de dor. Rio de Janeiro: Typografia Leuzinger, 1895a. . A <<Bororo >>. (Episódios Verdadeiros). Revista Brasileira, primeiro ano, abril a junho de 1895b., tomo II, pp. 193.196. . Lembranças de Matto Grosso. Rio de Janeiro: Typografia Leuzinger, 1897.

Ricardo Sequeira Bechelli, Civilização e barbárie no pensamento de Manuel González Prada. Amerika [En ligne], 17 | 2017, mis en ligne le 30 décembre 2017, consulté le 18 juin 2020. In: http:/journals.openedition.org/amerika/8312. Último acesso, 10/06/ 2020

ROJAS, Carlos Antonio Aguirre. Micro-História italiana, modo de uso. Trad. Jurandir Malerba. 2012.

ROMERO, S. História da Literatura Brasileira. (Org. Luiz Antônio Barreto). Rio de Janeiro: Imago; Aracaju - SE: Ed.UFS, 2001, $1 \mathrm{v}$.

ROSSATO, Luciano Alves; LÉPORE Paulo Eduardo. Comentários à Lei Nacional da Adoção- Lei 12.010, de 3 de agosto de 2009. São Paulo: RT, 2009.

SAID, E. W. L. Cultura e imperialismo. Trad. Denise Bottman. São Paulo: Companhia das Letras, 1995. 
Nos anos de 1990, o historiador e antropólogo John Manuel Monteiro sinalizou o quanto ainda prevalecia, no Brasil, uma lacuna sobre a questão indígena. Tal provocação se tornava mais contundente se fosse colocado na balança que, no âmbito da historiografia brasileira, havia diminuta incorporação de grupos sociais silenciados na vasta produção acadêmica. Nesse caminho, de fato, a antropologia ampliou as possibilidades de estudos - frente ao diálogo profícuo estabelecido com o campo da história -, envolvendo temáticas ricas, a exemplo da "inquisição", da "escravidão", das "relações de gênero", das "mentalidades", entre outros. Sendo assim: era "de estranhar a pouca atenção dispensadas aos povos indígenas pelos historiadores". (MONTEIRO, 1995, p. 221)

A par disso, Monteiro (1995, p. 222) reiterou que, desde o século XIX, um conjunto de intelectuais perante "os desafios políticos e limites teóricos" oriundos "de suas respectivas épocas, buscaram montar uma narrativa histórica" a respeito dos "povos da terra". Pensadores como Gabriel Soares de Souza, Simão de Vasconcelos, Carl von Martius, Karl von den Steinen, Darcy Ribeiro, Capistrano de Abreu, Florestan Fernandes tinham um lastro comum em seus escritos: a visão pessimista lançada sobre esses povoamentos. Porque, sim, todos esses intelectuais prognosticavam "o desaparecimento total dos povos indígenas", de modo que "a tese da extinção, sustentada por sucessivas correntes do pensamento social brasileiro" e, posteriormente, "reforçada pelas teorias que orientavam a antropologia no país encontrava na história uma sólida base de apoio".

Quinze anos depois, a estudiosa Maria Celestino de Almeida (2010), dialogando com as ponderações de Monteiro, indicava que, nas últimas décadas, ocorrera no país um avanço expressivo proveniente dessa estreita e frutífera relação entre historiadores e antropólogos. Ancorados nessa prerrogativa, os profissionais especializados em assuntos que envolviam as questões indígenas reformularam as antigas noções de cultura e identidade, que, antes percebidas como "fixas e imutáveis" (ALMEIDA, 2010, p.21), passaram a ser consideradas como constructos de processos históricos, emergidas das interações dinâmicas dos diferentes agentes envolvidos em situações específicas. A autora salientava, ainda, que parte dos grupos indígenas estudados estava deixando de ser 
subcategorias analíticas para ocupar espaços mais centrais, caracterizados pelo protagonismo histórico, situados como agentes sociais ativos. Contudo, isso não garantiu a superação total daquelas perspectivas teóricas uniformizantes que ainda reverberam na academia e que são debatidas pela autora.

Dentro dessas teorias mais uniformizantes, rogam a ciência universal, linear e racista da qual emana um conjunto de percepções pejorativas sobre os povoamentos indígenas, marcado por estigmas historicamente construídos. Tal versão universal, no contexto da antropologia, recebe guarida no que o antropólogo Viveiro de Castro (2011), embasado nos pressupostos teóricos de Levi-Strauss, denominou de "multicuralismo moderno". Assim, nessa dissociação entre duas séries paradigmáticas geradas em torno das noções de "natureza" e "cultura", "dadas" e "construídas", "objetivo" e "subjetivo", "animalidade" e "humanidade", entre outros, o "mundo natural" é simplificado e reduzido a uma perspectiva homogeneizante. Considerando a "implicação mútua entre unicidade da natureza e multiplicidade das culturas", (2011, p. 226), existiriam - nestas últimas - hierarquias sociais muito bem delimitadas e demarcadas por classificações nas quais o "homem ocidental" se coloca como referencial e centro do mundo.

Sem dúvida, Viveiro de Castro (2011, p. 227) critica essas linhas de pensamentos ocidentalizantes e nos convida ao "abandono de nossa herança intelectual dicotômica", nos ensinando a perspectivizar "as distinções efetivamente operantes nas cosmologias ameríndias". Dentro dessa prerrogativa, as concepções indígenas relevam a forma "como os seres humanos vêem os animais e outras subjetividades que povoam o universo deuses, espíritos, mortos, habitantes de outros níveis cósmicos, plantas, fenômenos meteorológicos, acidentes geográficos, objetos e artefatos" - na qual "é profundamente diferente do modo como esses seres vêem os humanos e se vêem a si mesmos" (2011, p. 227).

Mediante essas reflexões, ficam algumas indagações: como os historiadores, manipulando documentos históricos escritos e feitos por homens, brancos e ocidentalizados, podem praticar o perspectivismo? De que maneira podemos lançar outras versões que, sob uma ótica prosaica e denunciativa, colocam os grupos indígenas como protagonistas do passado e do presente, mirando um futuro positivo?

Para responder a essas questões, este capítulo dará atenção especial ao grupo indígena Guató. Analisando bibliografia montada sobre essa etnia, assim como relatos de naturalistas, cronistas e viajantes nacionais e estrangeiros, problematizaremos o quanto o campo da história pode encontrar entraves reflexivos que implicam a impossibilidade de acessar as particularidades da etnia tratada, recortando, temporalmente, os anos de 1830 
a 1930. Com a finalidade de indicar caminhos possíveis que possam ajudar a superar tais limitações, este capítulo centrar-se-á na importância das metodologias transdisciplinares, uma vez que, como posicionamento político demarcado na escrita científica, prioriza uma decolonização epistêmica que busca deslegitimar a "universidade ocidental" dos estudos acadêmicos a respeito do que se denomina como "América Latina" (MIGNOLO, 2011).

Para alcançar esse propósito metodológico e explicativo, não intencionamos colocar algo em seu lugar, mas, sim, reconhecer imperativos e racionalidades mais amplas do que as disciplinas acadêmicas. Logo: "desta posição é que podemos falar de uma atitude decolonial que suspende o método e propõem o manejo de um método sem métodos" (MALDONATO TORRES, 2016, p. 93). Tal perspectiva baseia-se na crítica contundente encampada por teóricos (as) localizados no mapa Sul do mundo; teóricos que exprobram e reprovam, de maneira enfática, a ciência moderna por utilizar-se do poder saber como controle das formas de dominação que também se dão pelo poder do ser. Isso porque tais exercícios de poder garantem privilégios e benefícios expressivos às populações do mundo ocidental no sistema capitalista mundial, galgando autoridades e apropriações de tudo que esteja relacionado a regiões geograficamente localizadas no mapa Sul do nosso planeta (pessoas, biomas, territórios, conhecimentos, culturas, recursos naturais entre outros).

Assim, a transdiciplinaridade decolonial pode ser definida "como orientação e suspensão de métodos e disciplinas a partir da decolonização como projeto e como atitude" (MALDONATO TORRES, 2016, p. 93). Objurgando e abandonando a ciência moderna, a atitude e o projeto pautam, diretamente, sobre a construção de uma consciência na qual "busca decolonizar, des-segregar e des-generar o próprio poder do saber e do ser" (MALDONATO TORRES, 2007a), criado na modernidade colonial a partir das noções de raça, gênero e trabalho. Estes últimos costuram as hierarquias mundiais até os dias atuais, como muito bem apontou a intelectual negra Carla Akotinere, a partir de suas reflexões em torno da interseccionalidade. (2019).

Nesse sentido, este capítulo estará dividido em três partes: em um primeiro momento, farei reflexões relativas às imagens "negativas" construídas sobre os povos Guatós e sua repercussão nos estudos acadêmicos - tendo como base o relato de viagem de Hercules Florance; em um segundo momento, enfatizarei a desmontagem dessas imagens com base numa perspectiva analítica transdisciplinar; e, por último, mobilizarei reflexões explicativas que "positivam" os olhares sobre a etnia tratada, de modo que suas relações com os não-indígenas e com a natureza sejam compreendidas a partir de um olhar interno, endógeno e colaborativo. 


\section{Da construção do saber para a construção do ser: invenções étnicas da América Latina, um estudo de caso sobre os Guatós}

Dentre as expedições científicas e de naturalistas realizadas no Brasil no século XIX, e que abarcaram a região que compreende o bioma do Pantanal, destaca-se a expedição russa organizada e idealizada pelo Barão Georg Heinrich von Langsdorff (1774-1852), o então cônsul-geral do império russo no Brasil. A expedição conseguiu reunir um conjunto de materiais de caráter informativo e descritivo ao avançar no interior do Brasil entre os anos de 1825-1829. A par disso, "um dos seus membros, o pintor viajante francês Hércules Florence (1804-1879), deixou um relato textual e iconográfico denso: o diário chamado de Viagem Fluvial do Tietê ao Amazônia". (PEREIRA, 2016, p. 29). É com base nesses escritos que farei algumas indagações a respeito da etnia aqui estudada, entrecruzando com outros documentos escritos e literatura feita a respeito dos Guatós. A escolha de tal relato não se deu de forma aleatória, tendo em vista que a mesma está recheada de comparações estabelecidas com outras etnias que também habitavam a região alagável, ou seja, o Pantanal.

Sobre os Guatós, Florence (1977, p. 118) declarou: "São bem feitos, robustos, de tez cobrada escura e cabelos escorridos, o que os prende ao tronco indiático, porque no mais parecem tipo europeu". E acrescentou: "Vi um homem de porte alto, boa figura e nariz aquilino: outros contudo, apresentavam o cunho característico da raça" (FLORENCE, 1977, p. 118). Quando os indígenas apresentam algumas semelhanças com o branco na sua fisionomia, características "positivas" são utilizadas, a exemplo da "boa figura" do "nariz aquilino", enquanto que os aldeados e moradores pantaneiros que se pareciam com os demais da "raça" não foram sequer comentados. O mesmo visitante dá continuidade à sua narrativa descrevendo:

Tive notícia de que outrora os Guatós de São Lourenço haviam morado entre os brancos e se misturado com eles, voltando porém depois, por gosto pela vida primitiva, aos antigos hábitos. Talvez daí venha a parecença com os europeus, sem que por isso tenham os cabelos e a cor sofrido alteração./ No meio do queixo crescem uns fios de barba/A fisionomia das mulheres e crianças é interessante: quando moças algumas são até bonitas./Dizem que os Guatós vivem com mais de uma mulher: a maior parte do que eu vi levava uma única. Lembro-me, porém, que numa ocasião troquei algumas palavras com alguns deles que tinha na sua canoa três mulheres. Perguntei-Ihe se todas eram suas; respondeu-me que sim. Pedi então por gracejo um e ele retorquiu-me zangado que eu deveria ter trazido comigo a minha. RepliqueiIhe que não fora possível isso. "Pois bem", disse-me ele, "Se você tivesse aqui sua mulher, eu trocava por uma destas" (FLORENCE, 1977, p. 118). 
Cabem aqui algumas reflexões sobre esse trecho, sobretudo, no que diz respeito às narrativas de viagens nos momentos em que se queria denunciar as ditas vidas "primitivas" nas quais muitos grupos indígenas discursivamente se achavam. $O$ contato e a relação dos índios com os grupos que thes eram externos serão expostos, sempre que possível, como aspectos assertivos dos desígnios "predestinados" para sair da posição classificatória na qual estavam "presos". Especialmente, se esses contatos, vistos sempre sob os olhos do domínio dos segundos sobre os primeiros, fossem condicionados por meio de aproximações de subordinação, que caracterizavam os respectivos "ganhos" a ambos os lados frente à batalha travada contra a "inadequada" convivência e valores locais. Nesse sentido, no que se refere ao campo privado, os Guatós serão percebidos pelo assombro temeroso da "perversão", cujos casais, despidos de instituições e normas familiares, de relações conjugais monogâmicas, estáveis e sagradas, estariam desencarnados dos preceitos morais tidos como modelo pelos visitantes. Seguindo o caminho oposto, esses indígenas viviam como pessoas "sem regras", "sem moralidades", "sem referências".

Assim, a menção ao indígena e suas esposas e o pouco apego conjugal a elas responde ao tom do que se entendia como "devassidão" que os casais estabeleciam, na qual a mulher é relegada a situações passivas em que seus futuros estariam "naturalmente" nas mãos de seus maridos. No escrito citado, era a figura masculina quem decidiria se a trocaria ou não por outra esposa, coisificando e desumanizando as figuras femininas, que estariam sendo duplamente inferiorizadas: por sua etnia e por sua raça - circunstanciadas pelo que a feminista negra Grada Kilomba coloca como "Outricidade" e pelo que a escritora Toni Morrison (2012) denominava como "dessemelhança". Isso é "a representação mental daquilo que o sujeito branco não quer parecer". Essa é "uma identidade relacional construída por brancas/os, que define a elas/es mesmas/os como racialmente diferentes das/os Outras/os", na qual o sujeito Guató é uma construção do homem branco, "fantasias" que não "as representam, mas sim o imaginário branco" (KILOMBA, 2019, p. 38).

Porque, sim, na construção de raça como instrumento desqualificador na classificação do sistema-mundo-capitalista, o gênero e a sexualidade são inerentes ao arsenal racista da colonialidade; especialmente, nas relações "desviantes" que escapavam ao modelo normativo civilizatório de família (SEGATO, 2012).

Dito de outra maneira, "uma análise decolonial pressupõe que se pense como raça (e classe) e gênero (re) produzem-se reciprocamente nessa construção moderna binária. É por isso que usar o gênero como categoria de análise em um trabalho brasileiro e latinoamericano" requer "mais do que falar de interseccionalidade de raça, classe e gênero", porque parte da prerrogativa de "analisar como essas categorias de opressão funcionam 
criando experiências diferentes". Logo, é imperativo compreender "essas categorias juntas, trabalhando em redes" que "são ao mesmo tempo causa e efeito" e se repercutem umas nas outras (GOMES, 2018, p. 71). Portanto, "categorias de branquitude e negritude, masculinidade e feminilidade, trabalho e classe" que "passaram a existir historicamente desde o início" da colonização (MCCLINTOCK, 2010, p. 39).

Sem dúvida, o "saber científico" inventado sobre a América Latina no século XIX merece ser situado, uma vez que isso nos proporciona identificar o lugar atribuído discursivamente a respeito dos povos indígenas. Estes estiveram fora da história oficial que se encontrava em processo de montagem no Brasil. No mais, quando eram mencionados, estavam aprisionados em aparições dualísticas e opositoras: "amigo x inimigo, colaborador x selvagem" (BRIGHENTI, 2018, p. 5). Eram atravessados, dessa forma, por uma herança colonial na qual o campo do poder saber instalava-se em duas direções. De um lado, firmava-se a "figura do tupi como dócil, amigo e heroico - mas que na visão da época não mais existia". Do outro lado, estava o seu avesso: "o tapuia, 'botocudo', que defendem seus territórios contra a penetração do capitalismo - indígena real presente no interior do Brasil" (BRIGHENTI, 2018, p. 5). Em Mato Grosso, não foi diferente, haja vista que os Guatós serão classificados como "dóceis", sem deixar de ser "selvagens" e "primitivos".

Na mesma linha de raciocínio, outra autora que nos ajuda a pensar a respeito dessa catalogação étnica criada pelos viajantes estrangeiros é a estudiosa Manuela Carneiro da Cunha (2002). A autora reiterou que tal visão dual dos oitocentos - fora da história construiu-se como estratégia política territorial feita de maneira intencional e amparada, historicamente, pelas retóricas coloniais - conforme mostrado acima. Nessa perspectiva, para Brighenti (2018), a elite agrária estava imbuída por seus pressupostos individuais e materiais calcados na apropriação dos territórios indígenas. Para legitimar tais práticas de invasões agrárias, aportavam-se na inferiorização das etnias locais suplantadas por teorias científicas as quais financiavam. Essa ideologia repercutiu no Instituto Histórico e Geográfico Brasileiro (IHGB). Destaca-se, ainda, que, segundo a autora Cunha (2002), no século XIX, ocorre um deslocamento argumentativo, pois a explicação religiosa da inferiorização indígena mobilizada no Brasil-Colônia cede espaço para a explicação científica dos anos oitocentos.

Contudo, conforme os escritos trazidos anteriormente, do viajante Florence, observamos uma documentação que nasce de um processo histórico no qual componentes religiosos e científicos se misturam, diluem a classificação racial perante elementos interpretativos acadêmicos e moralidades cristãs. 
Aliás, em meio a essa catalogação dos grupos indígenas, não restam dúvidas de que as informações difundidas sobre suas vidas íntimas, bem como suas vestimentas, sua postura frente os visitantes, suas relações internas, cumpriam o papel menos de noticiar e mais (do que o) de comprovar o quanto o processo de controle sobre seus destinos era coisa quase que imprescindível. Porém, a escala de dominação dependia muito do tipo de contato que se conseguia estabelecer com os nativos indígenas. Quanto mais "dóceis" fossem suas relações com os grupos hegemônicos, mais eram descritos como distantes de "anomalias", minimizando o que chamavam de propensão à "preguiça" ou atuação "perigosa" ou "ameaçadora". É nesse sentido que diferenciá-los internamente se tornava tão comum. Para se ter uma pequena ideia desse aspecto, observemos outro excerto, no qual o visitante, ao se referir aos Guaná, elaborou os seguintes comentários:

Estes índios, talvez por viverem menos expostos às intempéries que os outros, têm a tez mais clara do que quantas tribos em minhas viagens vi, com exceção dos Munducurus mansos do Pará. Quanto à fisionomia, possuem os traços gerais e característicos da raça mongólica, como acontece com os aborígenes do Brasil; achei-lhe, porém, um quê de ameno e de suave muito especial. Se não se chegam tanto ao tipo de europeu como os Guatós, não são contudo, indiáticos puros a modo dos Caiapós ou Xamacocos, dos quais tive ocasião de ver alguns indivíduos. Sem a expressão traiçoeira e má dos Guaicurus, nem a ferocidade dos Botocudos e dos Bororós, talvez se pareçam com os Apiácas, em todo caso é tipo digno de atenção e que apresenta um contraste interessante com 0 das outras nações indígenas (FLORENCE, 1977, p. 108-109).

Creio que alguns elementos podem ser explorados nesse fragmento de escrita. As descrições físicas são suplantadas por delimitações de personalidade, adjetivos são mobilizados para figurar a aparência articulada ao caráter pessoal dos indígenas. Os Borôros, Botocudos, Guaycurus - grupos tidos como verdadeiros "guerreiros" nas lutas estabelecidas contra as maneiras de exploração criadas por determinados segmentos da sociedade civil do período - são apontados como "traiçoeiros", "ferozes", "maus", enfim, com caráter altamente duvidoso, imersos no discurso do "mal selvagem". Já os Guatós, Caiapós, Chamacocos são comparados, em diferentes escalas, com estrangeiros e poucos comentários Ihes são atribuídos.

Para enfatizar a periculosidade de algumas sociedades indígenas, separando, nitidamente, os silvícolas "bons" dos silvícolas "maus" - mesmo que ambos estivessem atravessados por certa desvalorização de suas experiências cotidianas -, os interlocutores dos registros do período esboçavam um conjunto de práticas que passava a caracterizálos, definitivamente, em meio a investidas particulares que traziam um tom trágico, violento, calamitoso, funesto, sinistro. Essas investidas se posicionavam a favor da sociedade civil e 
não índio, de modo que colocavam na outra ponta, os indígenas, como grupos "perigosos", que ocasionavam danos sociais mediante os prejuízos humanos e econômicos incalculáveis e irreversíveis. Os referidos prejuízos davam-se não apenas nos quesitos morais, e sim, estendia-se a instabilidade provocada sob as famílias e cidadãos do Estado, os quais eram tratados na maioria das vezes "indefesos" e, portanto, suscetíveis ao pânico e veiculação de "ocorrências" de flagelos anunciados nos documentos tratados.

Veja bem, se os Guatós e os Guaná estavam pautados por visões do "selvagem amistoso", os Borôro recebiam percepções que nadavam contra a correnteza desse pensamento eurocêntrico sustentado e justificado pelas ações de hostilidade nas quais a tensão era instalada. Nas investidas etnocêntricas, o colonizador era a referência. Assim, os "nativos", na classificação racial, estavam circunscritos pela visão dual imposta sobre os índios: "aliados" e "inimigos" do Estado, conforme muito bem nos lembrou Almeida (2010, p. 31). A esse respeito, Florence não deixa dúvidas de sua percepção quando afirma sobre os Guatós: "A fisionomia não indicava selvajaria como a dos Bororos." (1977, p. 206)

Em outras palavras, nativos indígenas se tornam objeto e não sujeito de observação. Esse aspecto não deve jamais ser desprezado, pois abriga um caráter que, apesar de parecer simples, guarda em si certa complexidade: são grupos que merecem ser detalhados nas narrativas de viagem porque encontravam-se instalados nas bordas do Estado, regiões fronteiriças do país onde as diversas formas de identificação não se desvinculavam de ideias e práticas relacionadas à gestão e concepção do espaço público. Os indígenas, homogeneizados no âmbito "selvagem", possuíam variações internas. Entre os critérios de avaliação para saber o nível de sua propensão a "civilizar-se", sobressaem, dentre inúmeros aspectos, a intensidade ou não do seu "isolamento", de sua circulação espacial (e, portanto, da ausência da propriedade privada) e de sua passividade diante das ordens da colonialidade do poder para a apropriação de sua força de trabalho.

Retirando dos ambientes naturais que acessavam tudo o que necessitavam para a sua sobrevivência, os Guatós operavam uma diversidade de atividades rurais: a caça, a coleta e a pesca. Elas prescreviam mobilidade territorial - da qual tratarei com mais detalhes adiante. Tanto é assim que autores como Otto Urich (2001) identificou-os como povo nômade. Somado a isso, no relatório escrito sobre a catequese dos índios, endereçado a Augusto Leverger, José Viera (1856) afirmou que: "Quanto aos Guatós, continuam na sua vida errante, sem darem ainda a menor esperança de serem aldeados" (JOSÉ VIERA, 1856, p.3). Aos olhos dos não-índios, a mobilidade espacial agravava-se nessa espécie de nomadismo - ou seminomadismo - oriundo de um grupo que não possuía território definido. Percepção essa que era, obviamente, depreciativa e equivocada. 
No mais, importante observar que parte significativa dos elementos utilizados para substanciar essas percepções de Florence e de outros viajantes, insurgidas na primeira metade do século XIX, foi tão eficaz que ainda nos serve como ferramenta para sustentar interpretações bastante próximas dessa que estamos vendo. Anos depois, o engenheiro e militar belga Ferdinand Nijs, ao se referir à população mato-grossense, numa ótica articulada à noção de miscigenação racial, mais especificamente, mencionando as mulheres, exprimiu conteúdos homogeneizantes que, na identidade fixa, coloca padrões de referência, ridiculariza a diversidade feminina; enfim, reduz as diferenças sob o crivo de uma suposta ameaça que estes outros universos culturais, étnico e de gênero, inferem sob os grupos hegemônicos da época. Para ele:

Talvez vocês já tenham tido oportunidade de escutar pessoas se lastimando da degeneração de nossas raças europeias. (...) Deixem menosprezar descontentes pois, é certo após uma visita a Mato Grosso eles se regozijariam de pertencer à nossa raça (...). Imaginem vocês, pessoas de tez uniformemente pálida e doentia, preguiçosas, atingidas por uma espécie de languidez indolente que formaram uma imagem dos aspectos físicos dos habitantes de Mato Grosso. (...). Não. Esta raça é muito feia. Apesar do pó de arroz e dos fortes perfumes utilizados com frenesi pelas mulheres (...) elas em nada são comparáveis com nossas companheiras (Nijs, Ferdinand, 1868, p.8-9).

A herança colonial, nesses termos, ocasionava um corte entre a sociedade e a natureza inscrita em uma percepção racializada. A esse respeito, a natureza é animada enquanto a população local, miscigenada, é inanimada, afinal os adjetivos mobilizaos thes dão a sensação de inércia ("pálidas", "doentias", "preguiçosas" e "indolentes") . Um exemplo claro disso correspondente aos escritos do viajante Karl von dein Steinen (1942, p. 23), que, ao passar por Mato Grosso nos anos de 1884, afirmou: "Deixemos de divagações e sejamos mais práticos. Que abismo existe entre a poesia e a realidade (...) O que nos fascina é o que vemos, uma ou mais vezes, como turistas, porquanto só a idéia de viver aqui já sentimos horror". E acrescentou, "Com efeito as colônias humanas, ou melhor, inhumanas, estabelecidas por estes lugares são raras e podem-se contar a dedos". Assim, "A poesia, para esses viajantes era a parte natural da região, as paisagens, a flora e a fauna, a beleza natural e a diversidade das espécies que maravilhavam os olhares estrangeiros". Na outra ponta, encontrava-se "a realidade que se opunha a essa poesia", relacionada, então, à população. Logo, "Dessa forma se percebe que, para os viajantes, a única parte irrecuperável era o povo que habitava a região." (CRUZ, 2009, p. 68).

É nesses enunciados que a colonialidade do saber repercute um prisma de longa duração, mesmo que de maneira incompleta. Diluídos no conjunto de discursos, práticas sociais, atitudes morais e valorativas, projetos identitários e de invasões territoriais, têm 
como principal efeito a própria subalternização dos povos colonizados frente à permanência da hegemonia da nação colonizadora, em períodos que transcendem e ultrapassam a colonização (QUIJANO, 2005).

Todavia, suas práticas enunciativas no manancial científico reverberavam e circunscreviam-se em outras instâncias do poder, ou seja, na apropriação dos corpos por meio da colonialidade do ser. Tal ser universal detinha uma lógica dicotômica: o humano e o não humano - apresentando como quesito primordial ser ocidental ou não ocidental. Nesses termos: "Os povos indígenas das Américas e os/as africanos/as escravizados/as eram classificados/as como espécies não humanas - como animais, incontrolavelmente sexuais e selvagens". As famílias indígenas eram pensadas nessa ótica. No entanto, seus autores, os viajantes estrangeiros cientistas e naturalistas, colocavam-se como "O homem europeu, burguês, colonial moderno" que "tornou-se um sujeito/ agente, apto a decidir, para a vida pública e o governo, um ser de civilização, heterossexual, cristão, um ser de mente e razão" (LUGONES, 2014, p. 935).

Enquanto a mulher indígena Guató era aludida como um objeto da devassidão não humana, "a mulher europeia burguesa não era entendida como" o complemento à figura masculina europeia, "mas como alguém que reproduzia raça e capital por meio de sua pureza sexual, sua passividade, e por estar atada ao lar a serviço do homem branco europeu burguês". E foi assim que a "imposição dessas categorias dicotômicas ficou entretecida com a historicidade das relações, incluindo as relações íntimas" (LUGONES, 2014, p. 935). Contudo, com a finalidade de não sermos capturados por esses enunciados, podemos avançar um passo adiante a partir das metodologias transdisciplinares, que serão discutidas nas páginas seguintes.

\section{Desmontando a decolonialidade do ser Guatós: por uma metodologia transdisciplinar}

$\mathrm{Na}$ construção da colonialidade do ser Guatós, os componentes vigentes não eram apenas descrições das fisionomias étnicas, das caracterizações de personalidades ou, ainda, enunciações elaboradas a respeito de gênero e da sexualidade. Outro elemento que endossava tais versões ocidentalizadas era, como foi apontado, a sua relação com a natureza, que se arrastou até a primeira metade do século $X X$.

Entre os anos de 1929 e 1930, o militar Figuêiredo (1939) esteve presente na região que delimitava fronteira entre o Brasil e a Bolívia. Das suas impressões, elaborou estudos relativos a essas áreas e às pessoas que nelas residiam. No que diz respeito aos Guatós, 
descreveu-os como aqueles que não possuíam moradias, passavam parte do dia sobre canoas, feitas pelas suas próprias mãos, o que lhes propiciava navegar pelos rios como mestres (Figueirêdo, 1939, p. 207). A menção de que as principais estradas que os Guatós operavam eram as águas tinha um sentido peculiar, visto que entendiam o meio de transporte na acepção de casas, estadias contínuas, oriundas de uma imagem bastante em voga referente a esses "silvícolas". O juízo de valor do militar Figuêiredo - respaldado por certa ideia romântica que, na maioria das vezes, alocava esses nativos como parte integrante da natureza - transpõe, portanto, a opinião de que a sua interferência em relação ao ambiente em que viviam era bem limitada.

Ideias semelhantes podem aqui ser dadas como exemplo. Max Schmidt (1942, p. 249) afirmou que "Além de tudo isso os guatós é um habitante aquático por excelência; mais do que qualquer outra tribo do continente sul-americano". Já José Vieira Couto Magalhães (1873, p. 375) ressaltou que: "De Corumbá para cima é o país dos Guatós, tribo de navegantes eternos que, consubstanciados com suas canoas, quase como o caramujo com a sua concha", percorre distâncias longas, dado que "erra e vive por aquelas alegres e fartas regiões dos pantanais do alto Paraguai, S. Lourenço e Cuiabá”. Sobre a utilização dos recursos naturais, observou que "para o índio essa é a região onde a vida é fácil: a caça e o peixe são aí não só em grande abundância, mas tão facilmente colhidos que, para viver e gozar de abundância, não é necessário trabalhar". A pergunta que fica é: quando e por que emergiram tais percepções da relação dos Guatós com a natureza que envolve trabalho?

Começo por destacar a edificação explicativa e científica de um olhar que envolve o externo com as formas de vida locais. Reconhecidos por muitos estudiosos como "senhores do rio" e profundo conhecedores da fisionomia pantaneira, a percepção corrente sobre os Guatós, em parte retirada das tipologias documentais criadas sobre esse grupo, vem sendo cada vez mais discutida por guardar, de um lado, a simplificação e vulgarização do seu processo de espacialização e, por outro lado, elementos que trazem à tona universos mais implexos do que se possa imaginar. Articulado a essas leituras reducionistas, existe um conjunto de versões sociais que os imprimem como grupos "passivos", "amistosos", "semicivilizados"; como se, diante do processo de invasão territorial, tivessem resistido de forma amena contra os supostos "inimigos brancos".

Vários outros autores se aproximam das considerações delineadas acima. Segundo Jorge Eremitas (1995, p. 122), ao longo do século XIX, cronistas e viajantes se predispuseram a anotar os materiais que constavam nas habitações dos Guatós, tais como: 
"cabanas mal construídas" (Macerata, 1843, p. 4); "tosco barracão" (Castelnau, 1949, p. 321); "pequenos ranchos de ramagens, que fazem a pressa quando os ameaça a chuva" (Beurepaire-Rohan, 1869, p. 377-378); "pequenos ranchos em que dormem abrigados do tempo" (Leverger, 1862a, p. 216); pequenos e baixos ranchos construídos de galhos, paus e folhas de palmeiras, que são "apenas suficientes para abrigá-los do sol e da chuva" (Ferreira, 1993 [1905], p. 84); pequenas cabanas com ramos de árvores e folhas de palmeiras, somente para protegerem-se do sol e da chuva (Moure, 1862, p. 38); habitações muito rudimentares, um simples pára-vento com teto de folhas de palmeiras sobre quatro esteios (Monoyer, 1905, p. 156-157).

Assim, "rudimentar", "cabanas mal construídas", "ranchos" são terminologias recorridas para explicitarem as habitações desses indígenas. Nessa visão, os Guatós, completamente entregues ao ritmo peculiar das águas, que aparecem como se invadissem e assaltassem suas precoces vidas "primitivas", são comprimidos em meio à dura disponibilidade de recursos naturais, pouco manipulados e distantes de qualquer propensão a transformações mais contundentes. Esses moradores pantaneiros chamam a atenção dos viajantes e cronistas porque, diluídos no espaço e tempo do vai e vem das águas no Pantanal, não conseguem superá-los e ultrapassá-los, rendendo-se à cadência "rudimentar" que a natureza Ihes impunha. Em vez de protagonistas, tornam-se coadjuvantes diante de um cenário em que a flora e a fauna atuam com o papel principal. A simplicidade de seus atos é esboçada diante de aspectos relativos à vida material local, cuja moradia e canoa, que representam as condições de estalagem e circulação espacial primordiais para qualquer forma de vida, são mostradas como acanhadas, limitadas pelo tímido uso dos recursos que usufruem.

\begin{abstract}
Os Guatós apresentam exemplo raro de um povo sem nenhum liame nacional e que nunca se concentra em povoados; cada família leva vida isolada e constrói a sua moradia nos lugares mais inacessíveis. No meio de vastos pantanais ou de terras inundadas, avista-se uma pequena clareira em plena mata. Ali, sob o tosco barracão, instala o Guatós a sua morada; por mobiliário apenas algumas cabaças e peles de onça, animal que abunda na região e é alvo de encarniçada guerra. Não conhecem outra diversão afora a caça deste terrível animal que é atacado corpo a corpo, por meio de uma comprida lança, que o índio nunca abandona. Passam quase toda a vida em suas canoas, onde se refugiam com a família inteira quando as enchentes Ihes alagam os ranchos, forçando-os a passar semanas inteiras sem descer em terra (CASTELNAU, 1954, p. 321)
\end{abstract}

Muitos aspectos exibidos nesse trecho coincidem com os de outros relatos apresentados anteriormente. Esse é apenas mais um viajante que, ao traçar observações referentes às moradias e às atividades diárias dos Guatós, apregoa que eles devem ser compreendidos a partir do modo como praticavam a natureza. Nessa lógica, a residência dos nativos é, então, associada a "tosco barracão", pouco mobiliado, que, quando construído de forma temporária, se confunde com a mata densa e fechada que o cerca. No mesmo viés, são 
apresentadas as atividades necessárias para a proteção e alimentação, configuradas em meio a operações um tanto quanto precárias e simples. Contudo, a água é que se apresenta como atributo central à operação cotidiana, sempre perpetuada por meio da canoa, na qual a circulação espacial depende do bioma pantaneiro. Este teria influência expressiva na sobrevivência local, a ponto de possibilitar a construção de refúgios temporários, escondidos nos "lugares mais inacessíveis".

Veja bem, pois este dado é interessante: a mobilidade espacial dos Guatós é apresentada como uma ferramenta que ordena, organiza, estrutura o seu dia a dia local. Nesse âmbito, há de se considerar a maneira como são descritos no tocante aos contatos estabelecidos com as demais populações, haja vista que sua apresentação como nômades constantes gerava certo transtorno. Ainda que esses contatos não se estabelecessem de maneira tensa e hostil, dado que não possuem um lugar fixo, estável e preciso, os Guatós eram entendidos como nativos, que, mesmo amistosos, sequer faziam parte da sociedade civil e, menos ainda, eram capazes de estabelecer uma população unificada e contínua, que pudesse dividir suas dificuldades e limitações.

Considerando essas linhas de pensamento, compreendemos que devemos tomar cuidado para não nos apropriarmos e reproduzirmos tais visões. Em outras palavras, e concordando com a indígena Macuxi, Juile Dorrico: "citar o sujeito indígena como elemento exótico (...), ingênuo, vítima passiva, resistente à civilização" de maneira alguma "colabora para o conhecimento de diversas etnias, modos de vida, tradições existentes no país, mas sim para a recusa, ojeriza e negação desses povos no imaginário da cultura nacional" (2019, p. 254).

Tais ponderações são importantes, uma vez que problematizam a visão pejorativa sobre outras propostas de existências humanas. As imagens reducionistas sobre a etnia tratada estão sendo, cada vez mais, colocadas em xeque por não considerarem os motivos que levavam Guatós a fazer casas temporárias. Da mesma forma, tem sido possível repensar o papel desses nativos na paisagem pantaneira e o possível peso de sua organização social sobre ela. As suas paradas, lidas pelos grupos externos como "provisórias", "imprevistas", "irregulares" e "simples", deixavam escapar as relações mais amplas que esses grupos tinham não apenas entre si, mas, acima de tudo, com a sociedade que estava a sua volta.

Entre os estudiosos que se debruçaram sobre a cultura material dos conhecidos "canoeiros", destaca-se o já mencionado arqueólogo e arquiteto Jorge Eremitas, que colaborou com suas pesquisas de campo e suas reflexões metodológicas de caráter transdisciplinar. Para tanto, suas reflexões começam por derrubar a linha de raciocínio que 
coloca os Guatós como grupos meramente inertes no que se refere à prática da terra, já que as águas aparecem como parte da flora disputada e operada pelos nativos. $\mathrm{O}$ pesquisador pincela a paisagem de forma mais diversa ao atentar para o solo ocupado pelos índios canoeiros, uma vez que os Guatós não viviam em aldeias ou reunidos em bandos, grupos ou subgrupos, mas se constituíam como famílias autônomas, das quais umas mantinham certa interindependência em relação a outras (OLIVEIRA, 1995, p. 49).

Foi esse ponto que dificultou ao autor uma delimitação precisa da ocupação desses índios em diferentes contextos (OLIVEIRA, 2003). Explicitados, muitas vezes, como nômades que se concentravam nos lugares altos do Pantanal, o estudioso percebeu que a possibilidade dos Guatós ocuparem faixas de terras baixas e alagáveis era algo bem provável, pois as suas paragens permitiam desenvolver três tipos básicos de assentamento, todos localizados próximos aos cursos da água: "aterro" ou marrabóró, "beira do rio" ou modidjécum e "beira da morraria" ou macaírapó. O primeiro e mais importante para as famílias era ocupado, principalmente, no período da cheia. O segundo corresponde aos aterros e são praticados anualmente na estação seca, pois podem permanecer inundados durante meses, dependendo da intensidade da cheia. Já o terceiro é realizado em locais protegidos das inundações, muitas vezes, confundidos com outra paisagem local, conhecida como "morraria". Essas distintas ocupações anuais é que caracterizam a espacialização sazonal das famílias Guatós (OLIVEIRA, 1995, p. 72-73).

Nesse sentido, destacamos um dos mecanismos utilizados por esses grupos indígenas e que aflora vestígios do quanto as suas ações modificavam a paisagem: os "aterros". Os Guatós, estrategicamente, retiravam as terras férteis dos territórios mais baixos para depositá-las em partes mais elevadas: "e dessa forma dar vida a pobre, infrutífera e velha camada. A fertilidade do solo dos aterros e sua posição favorável a proteção das cheias favoreceu o surgimento de uma densa vegetação, inclusive com grandes árvores, tornando-se refúgio e moradia de uma densa fauna" (OLIVEIRA, 1995, p. 82). Esses espaços construídos pelos Guatós tinham o intuito de funcionar como "lugares de descanso", isto é, assentamentos temporários, com estrutura boa o suficiente para mantê-los provisoriamente; daí o emprego do cultivo e até mesmo de cemitérios nas suas proximidades. O mais interessante reside em seu processo de construção, já que, para o aterro, os Guatós recorriam a um trabalho coletivo sob a orientação de um "chefe" (ou madjô?). Este se responsabilizava em reunir indígenas e coordenar a construção de um novo marrabóro todas as vezes em que algum jovem do grupo se casava e não dispunha de um aterro para morar. Ou seja, por mais que não tivessem lugares transitórios que permitissem morar em um grande número de pessoas, isso não significava que estivesse 
perdida a possibilidade de se caracterizarem como um grupo indígena que tinha lógicas, valores e hierarquias sociais particulares e coletivas.

Aliás, os espaços de pousos dos Guatós, longe de constituírem lugares efêmeros, sem atribuição simbólica ou sagrada, a exemplo do cemitério, e desnudados de qualquer sentido produtivo, foram bastante discutidos pelo estudioso Oliveira. Conhecendo muito bem a flora e a fauna do Pantanal, esses indígenas montavam toda a sua redistribuição territorial, bastante fragmentada e com alto índice de mobilidade espacial, em torno das alterações que tinham condições de fazer sobre o meio que os cercavam. Para Oliveira, "os aterros eram construídos durante o período da seca, através do transporte, em cestoscargueiros de sedimentos, conchas de gastrópodes aquáticos e de bivalves" (OLIVEIRA, 1995, p. 92). Cada aterro pertencia a uma família, mas eventualmente podia agregar duas ou três, em virtude dos laços de consanguinidade - seus membros podiam ser numerosos, já que os Guatós eram polígamos. Quanto à estrutura de suas habitações, elas também desempenhavam funções distintas de acordo com a estação anual. Nas cheias, quando a mobilidade dos Guatós era maior, seus abrigos eram provisórios, basicamente com equipamentos de uso domésticos retirados do ambiente natural. Uso prático, esses ambientes possuíam pequenas dimensões, pois poderiam ser desfeitos e deslocados regularmente para outros lugares. De acordo com Oliveira, cada um desses abrigos "constituí-se de dois esteios centrais fincadas na terra e que sustentam um frechal improvisado por uma zinga", cuja cobertura era feita por "um de junco e outra de palma de acuri” (OLIVEIRA, 1995, p. 92). Além dessa, havia outro tipo de moradia, que necessitava de uma durabilidade maior, posto que era ocupada por semanas ou mesmo meses no período da seca. Essas habitações tinham uma planta baixa, retangular e toda aberta. Seu chão era batido e o teto do tipo "duas águas", sempre sustentado por esteios centrais e periféricos, a cobertura era de palha, feitas de palmas de acuri que chegavam próximo ao solo. Em outros termos, os diferentes tipos de moradas dependiam da época do ano em que eram feitos e dos lugares - baixos ou altos - onde eram construídos.

"Pescadores-canoeiros"! Ao referenciarem os Guatós dessa forma, sem dúvida, para além da representação a respeito desse grupo indígena, havia uma pequena dimensão da sua possível relação com a água. Nesse sentido, como um elemento central em suas vidas, a água não servia apenas como estrada que proporcionava deslocamentos ou cimento líquido que acomodava suas moradas temporárias, pois era também um lugar praticado em suas formas múltiplas. Dos rios, por exemplo, era retirado um dos principais mantimentos para sobreviverem: o peixe. Em reduto de um verdadeiro aquário onde se encontravam diferentes espécies ao longo do ano, os Guatós apanhavam esse alimento 
conforme sua própria noção cultural de sabor e aparência. Desse modo, se a arraia, o jaú, o cascudinho e a piquira não são munidos de uma aparência que lhes atraem, outros tipos de peixes já são bastante apreciados, a exemplo da cachara, o pacu, a pacupeva, o pintado, o dourado e outros - cozidos com algum vegetal em vasilhas de cerâmicas feitas pelas suas mãos (OLIVEIRA, 2003).

Contudo, não apenas a pesca entrava no rol das atividades realizadas anualmente, dado que a caça era outra prática bastante comum entre esses silvícolas. Ao desenvolvêla, esse grupo indígena figurado, muitas vezes, como manso, brando e afável, aponta o enfretamento a alguns tipos de animais que certamente seriam vistos externamente como detentores de grande coragem e audácia. Feita à base de arco e flechas ou bodoque, armadilhas, zagaia, a caça, como em qualquer outro lugar, demandava um conjunto de conhecimentos relacionados ao habitat e à alimentação das espécies a serem capturadas. É aqui, também, que novamente a água aparece como lugar operado, uma vez que algumas espécies se encontravam nos rios e córregos ou à sua margem, como o cervo-dopantanal, a capivara e o jacaré. Já outros animais, igualmente, de grande porte, encontravam-se em terra, mas também usavam a água como fuga, a exemplo da onça pintada. Se, para os Borôro, matar esse animal representava a assinatura simbólica de sua própria morte (não natural), entre os Guatós, a captura da onça pintada é compreendida como prestígio, pois, quanto mais espécies conseguissem apanhar, maior seria o número de mulheres que poderiam ter. Em outras palavras, o seu status de caçador era medido de acordo com a quantidade de onças que conseguisse matar (OLIVEIRA, 1995, p. 140). mais interessante refere-se à atividade feita em pequenas excursões. Ao realizarem essa tarefa em conjunto, a finalidade não se limitava, especificamente, à aquisição de alimentos. Consideravam, ainda, a importância de seus derivados, como a pele da ariranha e da lontra.

Se os Guatós apresentavam uma rotina vinculada estreitamente com a natureza, alinhando seu cotidiano e seus mundos de moralidades aos ciclos aquáticos do bioma Pantanal, fertilizando áreas poucos produtivas e retirando da flora e fauna a sua autossubsistência - imunes a um caráter destrutivo -, é possível afirmar que a retórica dos "índios-canoeiros" ocidentalizada era uma retórica não só pejorativa como, também, incompleta e atravessada por valores pessoais. Todavia, Oliveira, entrecruzando dados e prezando por compreender a natureza construída historicamente por esse grupo, conseguiu acessar a cultura Guató. Para tanto, o autor constrói seu estudo a partir da lógica transdisciplinar, que articula informações, coloca dados e saberes para confrontarem, analisam as práticas sociais para além do discurso científico. Esse é o primeiro passo para 
romper com a consciência moderna da atualidade. Almejamos ir um pouco mais além, ou seja, ver caminhos para que se possa atingir a consciência decolonial.

\section{Da consciência moderna para a consciência decolonial}

No ano de 2019, publiquei um capítulo intitulado "O homem que rege: 'homem pantaneiro', racismo ambiental e políticas de exclusão social", no livro "Racismo ambiental, Ecologia, Educação e Interculturalidade”. No texto, realizei uma discussão ambiental problematizando o quanto, dentro de uma ótica preservacionista e conservacionista, o Pantanal tornou-se uma paisagem mercadológica na qual turistas e cientistas têm disputado com a população local o acesso ao lugar e tudo que está sobre ele (flora, fauna, terra, água, trabalho, conhecimento, cosmologia...). Nessa arena de batalha, até então, os primeiros têm ganhado. Uma das pautas que mais justificam a facilidade e flexibilização da forma como tem operado o bioma em questão refere-se a uma rede de práticas discursivas, embaladas pelo ritmo cadente de leis, decretos e portarias, que impossibilitam as populações tradicionais pantaneiras de legitimarem suas formas de vida locais. Pesca, caça, migração do gado, coletas, circulação espacial, queimadas... enfim, atividades rurais imemoriáveis, atualmente, quando não proibidas, são permitidas de serem realizadas desde que circunscritas em maneiras amenas e bastante limitadas pelo Estado. Em outras palavras, o conjunto de iniciativas ambientais recentes inviabiliza as populações locais de desenvolverem suas rotinas construídas historicamente.

Para justificar tais ações ou iniciativas imersas em um projeto político de invasões territoriais - onde ocorre a construção de parques e reservas ambientais -, pressupõe-se a retirada das populações internas que ali habitavam. A finalidade dessas iniciativas ambientais é clara: apropriar e vender o bioma alagável a pesquisas científicas e turistas nacionais e estrangeiros, ficando perceptível o quanto os moradores são colocados como seres de grande ameaça ao bioma que está em disputa. Minimizam o caráter colaborativo das populações pantaneiras e impõem percepções e ideias que criminalizam suas ações. Estas, por sua vez, são enredadas em enunciações destrutivas, nas quais encarnam juízos que defendem a impossibilidade dos/as moradores/as saberem gestar a natureza que praticam, desdobrando no que Mészáros (2008, p. 162) denominou de "ilusão jurídica".

Do mesmo modo, reconhecemos a circunstância descriminada acima no que Morin Ávila chamou de racismo ambiental, explicitado "a partir de estos antecedentes históricos, los cuales han generado la injusticia ambiental, como el colorolario del despojo de sus territórios y de sus derechos ciudadanos" (ÁVILA, 2019, p. 17) 
Para Elizângela Cardoso de Araújo Silva (2018, p. 496), Indígena Pankararu, em muitos contextos, "As leis contemporâneas voltadas à proteção das demandas e necessidades próprias dos povos indígenas" e demais populações tradicionais "são resultado de muita luta, organização" e "articulação com os órgãos que atuam em sua defesa". Tais leis "estão constantemente ameaçados porque entram em confronto com os processos materiais, com a realidade econômica dos empreendimentos capitalistas de exploração dos recursos naturais". Essa tensão "atinge toda a classe trabalhadora porque ela se volta contra os trabalhadores do campo, contra as próprias formas de vida marcadas pela produção e reprodução da vida em conexões diretas com a natureza" (SILVA, 2018, p. 496).

Neste capítulo, tentei desmontar tais narrativas propaladas pelo Estado brasileiro. Nesse sentido, almejei colocar em questão o quanto a paisagem valorizada, disputada e concorrida no mundo mercadológico do turismo ambiental, teve a participação das populações tradicionais, no caso a etnia Guató, que, mediante seus conhecimentos locais, formas de vidas e cosmologias próprias, prezaram pelo desenvolvimento de uma etnociência colaborativa, produtiva e de transformações "positivas" sobre o bioma do Pantanal. Tal prerrogativa não caminha de forma solitária no mundo das correntes científicas das ciências humanas, tendo em vista que encontra guarida em intelectuais indigenistas, indígenas, ativistas e decoloniais.

Com base nesses pressupostos, os "aterros", devidamente estudados pelo arqueólogo e arquiteto Jorge Eremitas Oliveira $(1995,2003)$, devem ser pensados como a utilização do bioma que aciona "la autonomía ecológica" (NAVARRETE, 2015 p. 124). A partir de seus estudos com o levantamento da cultura material, é permitido indicar em que medida os "senhores canoeiros" Guatós possuem uma espécie de simbiose com o meio pelos quais circulam, montam seus universos simbólicos -integrando a natureza sem romper seus vínculos e suas interações com as paisagens a sua volta. Aliás, o autor nos dá indícios do quanto as paisagens ambientais possuem elementos naturais que nos proporcionam compreender as ações humanizadas que ali foram historicamente construídas. Isto é, o bioma, a natureza, a flora e a fauna Pantanal possuem um mundo cultural diverso que foi criado a partir do contato e das vivências estabelecidas com as inúmeras etnias que por ali circulavam na fluidez, dinâmica, atives e mutações de vidas coletivas. Demonstra em que medida o perspectivismo pode ser pensando dentro de uma ótica material e espacial.

Isso porque os "aterros", como uma prática de resistência, não promoviam esse corte ou essa separação entre as etnias indígenas e as naturezas. Como "autonomia ecológica", 
mobilizava a própria "capacidad que una comunidad tiene de reproducirse físicamente utilizando sus propias formas de producción". Essa autonomia estendia-se para além do terreno material, uma vez que atingia "también las dimensiones religiosas, rituales e identitarias de las relaciones que las sociedades indígenas habían establecido con la red de la vida en sus territorios a lo largo de siglos y milênios" (NAVARRETE, 2015, p. 12).

É por isso que suas ocupações étnicas incomodavam tanto, pois, como bem nos alertou Souza Santos (20015 s/n), "a vitalidade cognitiva do sul não deixou de ter consequências para o saber cientifico moderno, obrigado a reconhecer a existência de outros saberes, mesmo quando procura ciscunscrever a sua relevância, opondo-os de "conhecimentos locais" ou "etnociencia”. Assim, "não será surpreendente, por isto, que nos confrontemos, hoje, com uma crise epistemológica da ciência moderna", na qual, sem dúvida, "tal crise não reside apenas no inescapável reconhecimento de que há conhecimentos para além do conhecimento científico", uma vez que "ela resulta de desenvolvimento da própria dinâmica interna da ciência e, em particular, no reconhecimento da disjunção crescente entre modelização e previsão".

E mais, no tocante a uma possível descolonização da ciência, ocorre a necessidade em prescrever e admitir que "A injustiça social global está assim intimamente ligada à injustiça cognitiva global”, de modo que "a luta pela justiça social global também deve ser uma luta pela justiça cognitiva global. A justiça cognitiva global só é possível mediante a substituição da monocultura do saber científico pela ecologia dos saberes" (SOUZA SANTOS, MESENES \& NUNES, 2004, p. 100). Tais saberes foram secularmente, sobretudo, cunhados no mundo moderno, como manifestações culturais secundárias, muitas vezes, reduzidas a categorias analíticas criadas pejorativamente pela ciência ocidental: curandeirismo, feitiçaria, pajelança, xamanismo, animismo, totismo e, recentemente, denominado etnociência (LEVI-STRAUSS, 2003). Muitas dessas expressões culturais estão inscritas em seus mundos diários, ritualísticos, identitários e de territorialidades que demarcam suas diferenças e especificidades como grupos sociais.

Nos últimos anos, tem se visto um esforço de retirar a carga negativa jorrada sobre essas denominações, a partir do direcionamento de conexão entre os saberes, tornando mais flexíveis as pontes de comunicação entre os campos dos conhecimentos, sejam aqueles descritos como "etnoconhecimentos", sejam aqueles descritos como "acadêmicos". A par disso, basta salientar que documentos escritos podem ser utilizados nos estudos decoloniais, mediante as contraversões de seus autores, haja vista que, longe de esboçar dados objetivos, verossímeis e completos, estão carregados de impressões subjetivas, distorcidas, pré-concebidas e fragmentadas e que, muito mais do que falar sobre as 
populações locais, falam mais sobre os mundos referenciais de seus autores. Longe de um olhar técnico e absoluto, devem ser tratados como notícias individuais entrelaçadas, a "bases das linhas seculares e ontológicas moderno-coloniais". (MALDONADO TORRES, 2015, p. 94)

Se pesquisadoras/es conseguiram "criar laços e novas formas entre esferas que a Modernidade ajudou a separar: a esfera da política ou do ativismo social, a esfera da criação artística e a esfera da produção de conhecimento", então avançaremos um passo adiante para nos desvincularmos da consciência moderna e nos aproximarmos da consciência decolonial. Isto é, termos uma postura na escrita que, na perspectiva decolonial, "acarreta formas de atuar, de ser e de conhecer que se alimentam dos encontros entre estas áreas" (MALDONADO TORRES, 2015, p. 94). Em outras palavras, "a consciência decolonial" é uma "operação limítrofe, cujo pensamento também é um pensamento de fronteira que se alimenta, literalmente, da experiência de estarem impregnados pela linha ontológica moderno-colonial" (ANZALDÚA, 2012, p.94).

Somado a isso, "o caráter fronteiriço do pensamento decolonial também aponta para seu caráter transdisciplinar: o projeto e a atitude decolonizadora leva o sujeito cognoscente que emerge da zona do não ser a alimentar-se do ativismo social" que "não tem uma linha certa, estável, visível" (MALDONADO TORRES, 2015, p. 94). Isso porque "o encontro de fronteiras entre o conhecimento que se impõe a partir da zona do ser com a experiência e o conhecimento que se dão na zona do não ser e simultaneamente o encontro entre as distintas esferas do pensamento", tanto da ação quanto da criação, onde se instala o "sujeito em processo de decolonização", faz com que estes desafiem "a rigidez das disciplinas e seus métodos" (MALDONADO TORRES, 2015, p. 94) e mirem em práticas transgressoras de maneira "positivada". Foi essa a proposta do presente capítulo.

\section{Bibliografia}

AKOTINERE, Carla Interseccionalidade. São Paulo: Sueli Carneiro ; Pólen, 2019.

ALMEIDA, Maria Regina Celestino de. Os índios na História do Brasil. Rio de Janeiro: FGV, 2010. 167 p. (Coleção FGV de Bolso, 15).

ÁVILA, José Morin. Apresentação. In: SCUDDER, Priscila de Oliveira Xavier; GONZÁLES, José Morin; ÁVILA, Carlos Frederico Domingos. Racismo Ambiental, Ecologia, Educação e Interculturalidade. Campo Grande/MS: Life Editora, 2019, p. 11-30.

BRIGHENTI, Clovis Antonio. Apresentação do Dossiê sobre povos indígenas e estudos decoloniais. In: Epistemologias do Sul. Foz de Iguaçú/pr. 2 (2), PP. 5-12, 2018.

BORGES, Ana Carolina da Silva. O homem que rege: 'homem pantaneiro', racismo ambiental e políticas de exclusão social. In: SCUDDER, Priscila de Oliveira Xavier; 
GONZÁlES, José Morin; ÁVILA, Carlos Frederico Domingos. Racismo Ambiental, Ecologia, Educação e Interculturalidade. Campo Grande/MS: Life Editora, 2019, p. 31-60.

CASTRO, Eduardo Viveiros de. A inconstância da alma selvagem e outros ensaios de antropologia. São Paulo : Cosac Naify, 2011.

CRUZ, Paulo Divino Ribeiro da. A influência do racismo na educação Mato-grossense na Transição do século XIX ao XX. / Paulo Divino Ribeiro da Cruz. - Cuiabá (MT): O Autor, 2009.

CUNHA, Manuela Carneiro da. Apresentação. In: ALBERT, Bruce; RAMOS, Alcida Rita. Pacificando o branco. Cosmologia do Contato no norte-amazônico. São Paulo: UNESP, Imprensa Oficial do Estado, 2002.

CUNHA, Manuela Carneiro da. História do índio no Brasil. São Paulo: Companhia das Latras, Secretaria Municipal de Cultura/FAPESP, 1992.

DORRICO, Julie. A estrutura do homem integrado à natureza como princípio da literatura brasileira contemporânea. Espaço Ameríndio, Porto Alegre, v. 13, n. 2, p. 242-267, jul./dez. 2019.

GOMES, Camilla de Magalhães. "Gênero como categoria de análise decolonial". In: Revista Civitas (Dossiê: Gênero e sexualidade). Porto Alegre, v. 18, n. 1, p. 65-82, jan.-abr. 2018.

KILOMBA, Grada. Memórias de Plantação: episódios de racismo cotidiano. Rio de Janeiro: Cobogo, 2019.

LÉVI-STRAUSS, Claude. 2003. O feiticeiro e sua magia. 6. ed. In: Antropologia estrutural. Rio de Janeiro: Tempo Brasileiro.

LUGONES, María. Rumo a um feminismo descolonial. In: Estudos Feministas, Florianópolis, 22(3): 935-952, setembro-dezembro/2014, p. 935-952.

MCCLINTOCK, Anne. Couro imperial: raça, gênero e sexualidade no embate colonial. Campinas: Unicamp, 2010.

MÉSZÁROS, Istvan. Marxismo e Direitos Humanos. In: Filosofia, Ideologia e Ciência Social. São Paulo: Boitempo, 2008.

MONTEIRO, John Manuel. O desafio da história indígena no Brasil. In: LOPES DA SILVA, Aracy; GRUPIONI, Luís Donisete Benzi (Orgs.). A temática indígena na escola: novos subsídios para professores de 1‥ e $2^{ }$. graus. Brasília: MEC/ Mari/ Unesco, 1995. p. 221 28.

NAVARRETE, Federico. Linares Hacia otra historia de América. Nuevas miradas sobre el cambio cultural y las relaciones interétnicas México Universidad Nacional Autónoma de México, Instituto de Investigaciones Históricas 2015.

OLIVEIRA, Jorge Eremitas. "Da pré-história à história indígena: $(\mathrm{Re})$ pensando a arqueologia e os povos canoeiros do pantanal". Revista Arqueologia, 16: 71-86, 2003. 
OLIVEIRA, Jorge Eremitas. Guatós: argonautas do Pantanal. Dissertação de Mestrado apresentada ao Programa de pós-graduação e história, com área de concentração em arqueologia. Porto Alegre. PUC, 1995.

PEREIRA, Sonia Maria Couto. Etnografia e iconografia nos registros produzidos por Hercules Florance durante a expedição Langsdorff na província de Mato Grosso (18261829). Dourados, MS: Ed. UFGD, 2016.

QUIJANO, Anibal. Colonialidad del poder y classificacion social. Journal of WorldSystems Research, v. 6, n. 2, p. 342-386, 2000.

SANTOS, B. S.; MENESES, M. P.; NUNES, J. A. Introdução: Para ampliar o cânone da ciência: a diversidade epistemológica do mundo. In: SANTOS, B. S. (org.). Semear outras soluções: os caminhos da biodiversidade e dos conhecimentos rivais. Porto: Afrontamento, 2004.

SEGATO, Rita Laura. Gênero e colonialidade: em busca de chaves de leitura e de um vocabulário estratégico descolonial. E-cadernos CES (Online), v. 18, p. 1-5, 2012.

SEGATO, Rita Laura. Género, política e hibridismo en la transnacionalización de la cultura yoruba. In: Rita Laura Segato, Las estructuras elementales de la violencia. 2. ed. Buenos Aires: Prometeo, 2013a. p. 221-248.

SILVA, Elizângela Cardoso de Araújo. Povos indígenas e o direito à terra na realidade brasileira. In: "Serv. Soc. Soc., São Paulo, n. 133, 2018, p. 480-500.

ULRICH, Otto W. Os curandeiros indígenas. S.I., ano 3, n. 35, jul. 2001. Disponível em: . Acesso em: 23 abr. 2003

\section{Documentos citados}

Castelnau, Francis. Expédition dans les parties centrales del l'Amérique du Sud, de Rio de Janeiro a Lima, et de Lima au Para. Histoire du voyage. Paris, 1850-1851. 6 t. apud BALDUS, Herbert. Bibliografia crítica da etnologia brasileira. São Paulo: Comissão do $4^{\circ}$ Centenário da Cidade de São Paulo, Serviço de Comemorações Culturais, 1954.

Figuêiredo, Lima. Índios do Brasil. São Paulo: Companhia Editora Nacional, 1939.

FLORENCE, H. Viagem fluvial do Tiete ao Amazonas: 1825-29. Editora de São Paulo, São Paulo Cultrix, 1977.

Magalhães, José Vieira Couto. Ensaio de anthropologia: região e raças selvagens. Revista trimensal do Instituto Histórico, Geographico e Ethnographico do Brasil. Rio de Janeiro: B. L. Garnier, 1873.

Max Schmidt, Estudos de etnologia brasileira. Peripécias de uma viagem entre 1900 e 1901; seus resultados etnológicos. Tradução de Catharina Baratz Cannabrava. São Paulo: Companhia Editora Nacional, 1942b. (Coleção rasiliana - Série 5ª

MOUTINHO, J. F.Notícias sobre a Província de Mato Grosso.São Paulo, Henrique Schardez, 1868. 
STEINEN, Karl von dein.O Brasil central: expedição em 1884 para exploração do rio Xingu. São Paulo, 1942.

VIEIRA, Henrique José. Relatório do estado da catechese e civilização dos Indígenas da Província de Mato Grosso. Cuiabá: Arquivo Público de Mato Grosso, 1856. Transcrição de Elizabeth Madureira Siqueira. 


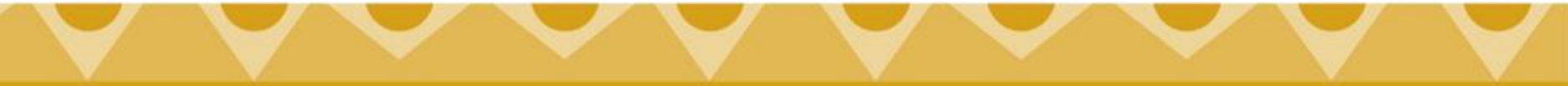

I/ / / / / / / / I

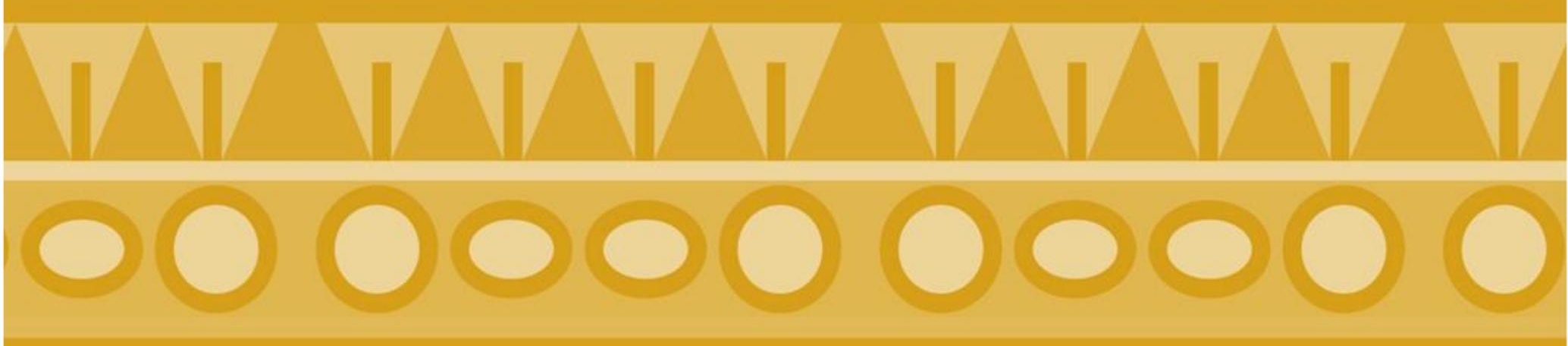

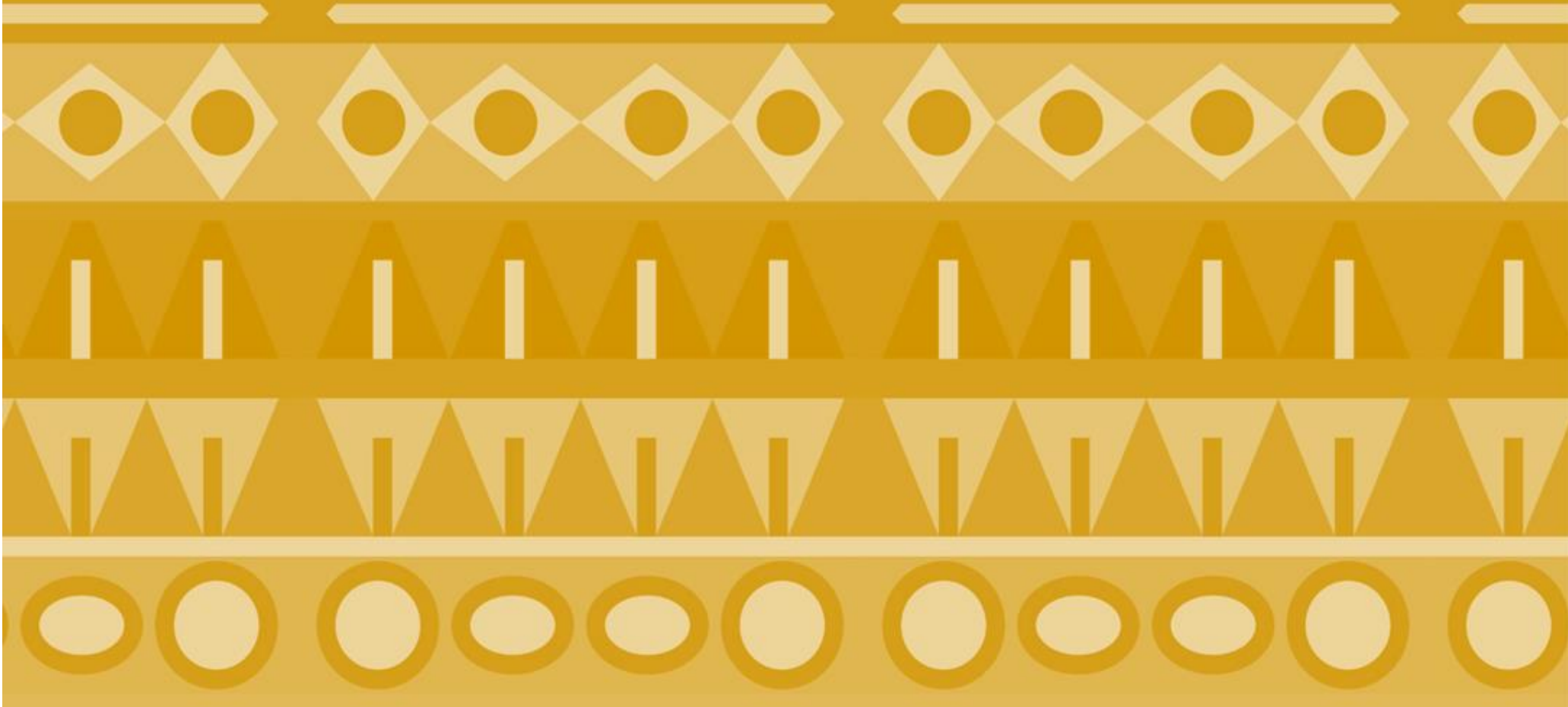

00000000000

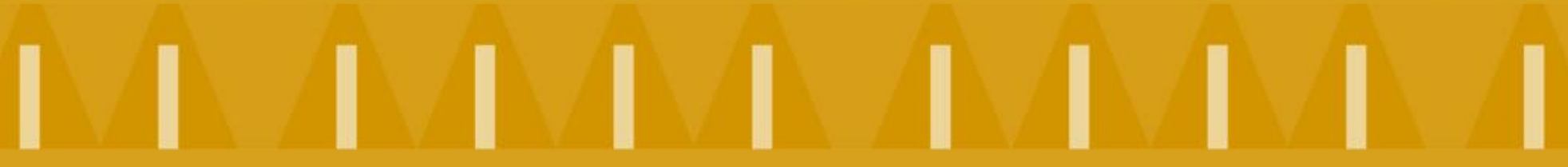

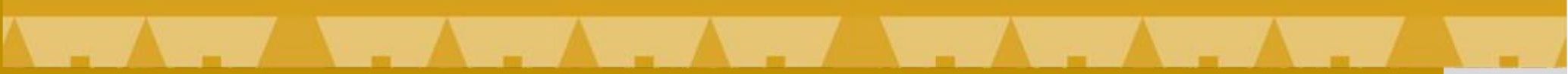

